UNIVERSIDADE DE SÃO PAULO

FACULDADE DE FILOSOFIA, LETRAS E CIÊNCIAS HUMANAS

DEPARTAMENTO DE HISTÓRIA

MESTRADO EM HISTÓRIA SOCIAL

\title{
EXPERIÊNCIAS DE MORADIA:
} HISTÓRIA ORAL DE VIDA FAMILIAR

Aluna: Xênia de Castro Barbosa

Orientador: José Carlos Sebe Bom Meihy

São Paulo, 2009 
XÊNIA DE CASTRO BARBOSA

\section{EXPERIÊNCIAS DE MORADIA:} HISTÓRIA ORAL DE VIDA FAMILIAR 


\section{EXPERIÊNCIAS DE MORADIA: HISTÓRIA ORAL DE VIDA FAMILIAR}

Xênia de Castro Barbosa

Dissertação de Mestrado apresentada ao Programa de Pós-Graduação em História Social do Departamento de História da Faculdade de Filosofia, Letras e Ciências Humanas da USP, para a obtenção do título de Mestre em História Social.

Orientador: Prof. Dr. José Carlos Sebe Bom Meihy. 
Aos meus colaboradores:

Laura, Antonio, Maria da Paixão, Luana, Cássio, Filipe, Bárbara, Marcos, Lady, Ana Terra, Silvana, Carolina, Camila, Caio, Carla, Marcelo e Junior, que lutam por um mundo melhor. 


\section{AGRADECIMENTOS}

A meus pais: Mário Chagas Barbosa e Valassil de Castro Barbosa e a meu irmão Aécio

- que me ensinaram o mais importante e ao longo de todos esses anos têm agido com paciência e generosidade para comigo, me apoiando incondicionalmente.

A Sofia - minha filha - que veio para me fazer uma pessoa melhor, Tiago - meu esposo pelo incentivo e carinho, e a minha tia Maria José - que me acolheu em sua casa em São Paulo para que eu pudesse realizar esse mestrado.

Não poderia deixar de expressar minha gratidão a meus amigos: Andréa Paula, Cássia, Marcela, Márcia, Maria Isabel, Vanessa Paes, Vanessa Rojas e Suzana Ribeiro - que partilharam comigo suas experiências de vida e pesquisa; e a André, Bruno, Lucas e Márcio, pelas melhores aventuras narrativas.

Sou grata aos meus professores do Centro de Hermenêutica do Presente: Fabíola Holanda Barbosa, Alberto Lins Caldas e Nilson Santos, que me ensinaram a pensar diferente e a ler diferente; e ao Núcleo de Estudos em História Oral da USP, pela formação e interlocução em história oral.

Agradeço especialmente ao Professor José Carlos Sebe Bom Meihy, que confiou em mim e pacientemente me orientou, e às professoras Fabíola Holanda e Zilda Iokoi, pelas valiosas observações no exame de qualificação. 


\section{RESUMO}

Esta pesquisa propõe um registro de aspectos da experiência de vida de duas famílias: uma que reside em Porto Velho e outra que tem membros em São Paulo e Itapecerica da Serra. Dentre a complexidade de suas experiências, procuramos analisar suas lutas por moradia, percepções da cidade e o ordenamento de seus projetos familiares. Para isso realizamos três anos de trabalho de campo, registramos e analisamos suas histórias de vida, elaboradas mediante procedimentos e noções da história oral.

O texto está organizado do seguinte modo: Parte I: Apresentação, História do Projeto, Considerações sobre o Corpus Documental, sobre o Tema da pesquisa e a Leitura em história oral; Parte II: Narrativas de uma família de São Paulo, na qual apresentamos 10 histórias de vida de familiares e agregados que se consideram pertencentes a essa família, e Narrativas de uma família de Porto Velho, em que expomos seis histórias de vida de integrantes daquela família; Parte III: Leitura e Interpretação, na qual analisamos as histórias de vida apresentadas no capítulo anterior.

PALAVRAS-CHAVE: história oral, família, memória, cidade, experiência.

\section{ABSTRACT}

This research considers a study on aspects of the experience of life of two families: one that inhabit in Porto Velho and one that has members in São Paulo and Itapecerica da Serra. Amongst the complexity of its experiences, we look for to analyze its fights for housing, perceptions of the city and the order of its familiar projects. For this we made three years of field work, we register and we analyze its histories of life, elaborated by means of procedures and slight knowledge of oral history.

The text is organized in the following way: Part I: Presentation, History of the Project, reflections on the Documentary Corpus, the Subject of the research and the Reading in oral history; Part II: Narratives of family of São Paulo, in which we present 10 histories of life of familiar and added that if considers pertaining this family, and Narratives of a family of Porto Velho, where we display six histories of life of integrant of that family; Part III: Reading and Interpretation, in which we analyze presented histories of life in the previous chapter.

KEY-WORDS: oral history, family, memory, city, experience. 


\section{SUMÁRIO}

\section{PARTE I:}

HISTÓRIA DO PROJETO 01

UM POUCO DA TRAJETÓRIA

A ESCOLHA DO TEMA 03

OS PROCEDIMENTOS $\quad 05$

CADERNO DE CAMPO 11

CONSIDERAÇÕES SOBRE O TEMA DA PESQUISA 22

CONSIDERAÇÕES SOBRE O CORPUS DOCUMENTAL 25

PARTE II:

NARRATIVAS DE UMA FAMÍLIA DE SÃO PAULO E ITAPECERICA DA SERRA (SP) 27

ANA TERRA 28

TONHO 51

LAURA 53

MARIA DA PAIXÃO 63

LUANA $\quad 75$

CÁSSIO

FILIPE $\quad 84$

MARCOS 95

$\begin{array}{ll}\text { LADY } & 101\end{array}$

BÁRBARA 104

NARRATIVAS DE UMA FAMÍLIA DE PORTO VELHO (RO) 112

JUNIOR 113

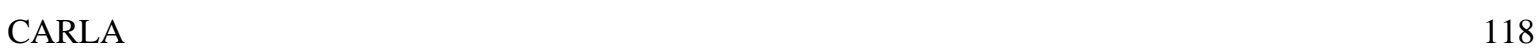

CAROLINA

$\begin{array}{ll}\text { CAMILA } & 147\end{array}$

CAIO 136

MARCELO 143

PARTE III:

REFLEXÕES SOBRE A LEITURA EM HISTÓRIA ORAL 147

ANÁLISE DAS NARRATIVAS 150

DO QUE FALAM OS TEXTOS

RECORDAÇÕES SOBRE A INFÂNCIA

RECORDAÇÕES SOBRE OS PAIS 156

RECORDAÇÕES SOBRE A ESCOLA 157

PROBLEMAS E VIRTUDES DA CIDADE 158

REFLEXÕES SOBRE O EIXO DA PESQUISA 164

MEMÓRIA, IDENTIDADE, COMUNIDADE 166 
OS SENTIDOS DO TER E OS MOVIMENTOS SOCIAIS

MOVIMENTOS SOCIAIS E A LUTA NA CIDADE

PARTE IV:

\section{CARTOGRAFIAS URBANAS}

190

PRODUÇÃO E APROPRIAÇÃO DO ESPAÇO URBANO

196

O MTST E A REFORMA URBANA

198

ALIMENTAÇÃO

200

SABORES DO CAMPO

201

SABORES DA CIDADE

203

MÍSTICA: ARTE DA VIDA TERRENA

210

CONSIDERAÇÕES FINAIS

214

BIBLIOGRAFIA

216

ANEXOS

223

GALERIA 


\section{APRESENTAÇÃO}

O presente trabalho é resultado de estudo realizado ao longo de 2006, 2007 e 2008, em colaboração com famílias de São Paulo/Itapecerica da Serra (SP) e Porto Velho (RO). Famílias que àquela época se relacionavam, em alguma medida, com Movimentos Sociais ${ }^{1}$.

O objetivo do estudo foi, em primeiro lugar, estabelecer textos que registrassem as experiências de vida daquelas famílias, registro que poderia não existir não fosse o nosso trabalho. A história oral foi o caminho trilhado para se ter acesso às narrativas dessas experiências e compreender como aquelas famílias interpretam e organizam suas vivências. Essas narrativas apresentam aspectos da cultura nordestina e nortista, suas especificidades culinárias, que embora possam ser consumidas, hoje em dia, em "qualquer lugar do país”, não possuem o mesmo sabor de quando consumidas na infância ou na terra natal. Mas as histórias de vida apreendidas por meio de procedimentos da história oral não se limitam a esse aspecto, falam também de experiências de moradia, de política, de relações familiares e sociais, de delícias e dramas vividos em família.

Cada entrevista que realizava trazia algo de novo e retomava elementos das anteriores, desenrolando o novelo de convergências e divergências próprio da vida em família e da vida em comunidade. Trazia a elaboração e negociação de projetos: os familiares e os políticos, que encontraram convergência na narração de alguns colaboradores. O projeto familiar depreendido por meio das histórias tem como objetivo a melhora das condições de vida daquele grupo, e o projeto político, a transformação social. O traço em comum que une os dois é o desejo de ter uma casa para morar e o entendimento de que esse desejo é legítimo. A necessidade premente de moradia e o entendimento de que ela é um "direito do cidadão" favoreceu o ingresso de membros dessas famílias em dois movimentos populares brasileiros, o insurgente Movimento dos Trabalhadores Sem-teto de Rondônia e o Movimento dos Trabalhadores Sem-teto de São Paulo (MTST).

O primeiro ainda está em formação, não possui estrutura definida, bandeira, sigla, manifestos. O segundo nasceu em 1997, por ocasião da primeira marcha nacional

\footnotetext{
${ }^{1}$ Estas famílias têm integrantes que participaram das ocupações João Cândido, em Itapecerica da Serra, e Chico Mendes, em Porto Velho. Essas ocupações foram organizadas, respectivamente, pelo MTST e pelo Movimento dos Trabalhadores Sem-teto de Rondônia.
} 
do Movimento dos Trabalhadores Sem Terra (MST). A princípio, o MTST teve como campo de atuação “apenas” a região metropolitana de São Paulo e só a partir de 2007 passou a organizar atos e acampamentos nos diversos estados do país. Vimo-nos então diante do desafio de compreender as relações que essas famílias estabelecem entre seus membros e com o Movimento Social com o qual se identificam. Ressaltamos que os graus de envolvimento e identificação desses sujeitos com aqueles Movimentos Sociais vão desde a militância incondicional: a vida em acampamento, participação em atos e novas ocupações, até a participação ocasional, o apoio intelectual, emocional e material aos familiares que integram esses Movimentos. Salientamos também que essas identidades não são estáticas, definitivas e estão em constante elaboração.

O desafio pareceu maior quando, ao buscar publicações sobre o assunto em bibliotecas e bancos de teses de universidades do Estado de São Paulo, não encontramos nenhuma que tivesse tratado o problema por viés historiográfico. Também os documentos existentes, se comparados aos que se referem a outros Movimentos Sociais, como ao MST, por exemplo, e às informações sobre famílias em busca de moradia, me pareceram insuficientes: um site em fase de construção, notícias de jornais, panfletos, estatísticas questionáveis, produzidas pelas prefeituras municipais. Esses documentos não davam acesso à subjetividade das famílias, ao modo como sentem e organizam a vida, elaboram suas identidades e às especificidades do seu jeito de lutar. Tal problemática conduziu-nos a realizar entrevistas de história oral de vida, que somadas a anotações do trabalho de campo e anotações sobre reuniões e assembléias das quais participei, constituem as fontes desta pesquisa.

A história oral é vista neste trabalho como "uma prática de apreensão de narrativas feita mediante o uso de meios eletrônicos e destinada a recolher testemunhos, promover análises de processos sociais do presente e facilitar o conhecimento do meio imediato" 2. Ela é capaz de sondar, mediante processo transcriativo, estruturas e instâncias da experiência que normalmente estão "restritas aos consultórios de Psicologia, aos segredos de família, às intimidades ou ao mistério não-dito da vida, podendo, desse modo, chegar aonde normalmente o conhecimento historiográfico, antropológico ou sociológico tradicional não vai” ${ }^{3}$. A opção pela história oral como metodologia desta pesquisa levou em conta o imperativo ético de construção da

\footnotetext{
${ }^{2}$ MEIHY, José Carlos Sebe Bom. MANUAL DE HISTÓRIA ORAL. $5^{a}$ ed. São Paulo: Ed. Loyola, 2005: p.18.

${ }^{3}$ Ver artigo de Alberto Lins Caldas (URL:

http://www.unir.br/ albertolinscaldas/artigos/transcriacao.html).
} 
cidadania, e esta, como sabemos, possui como um de seus pré-requisitos a liberdade de expressão para contrapor pontos de vistas. Não poderíamos, ao trabalhar com pessoas que vivem as contradições do tempo presente, expresso num processo histórico de espoliação que não é só econômica, de bens materiais, como casa ou escola, mas de dignidade, escolher uma metodologia que não as colocasse como centro da pesquisa. Ao tornarem-se colaboradoras, assumirem a elaboração do texto que apresenta sua versão da história, temos acesso a um universo rico em experiências vivenciadas coletivamente.

A história oral de vida, em sua perspectiva voltada para o estudo de famílias foi selecionada nesta pesquisa porque possibilita ver não apenas a aglutinação das histórias de vida dos indivíduos de um mesmo grupo, mas por favorecer a “compreensão, identificação, retomada e/ou construção de um projeto familiar que organiza, através de gerações, a trajetória do grupo ${ }^{4}$.

Quando se fala em família, o modelo que nos vem ao pensamento é o da família patriarcal apresentada pelo sociólogo Gilberto Freyre ${ }^{5}$. Uma família extensa, composta por esposa, filhos legítimos e extraconjugais, parentes, amigos, afilhados, dependentes, trabalhadores escravos, etc - submissos à figura do chefe de família, que gozava de poder econômico e social e tinha prerrogativas para dispor de suas propriedades como lhe aprouvesse. O prestígio do qual os patriarcas gozavam provinha dentre outras coisas, da dependências financeira de seus familiares e agregados. O jurista Camargo Viana destaca que naquela sociedade predominava a monocultura, na qual

[...] o trabalho era restrito, era cíclico, havendo o período das colheitas, mas também o período de quiescência, no qual as plantações ficavam em estado de crescimento, isto [...] deixava as pessoas ociosas e dependentes do chefe de família, daquele pater que era o dono da gleba, era o senhor da terra, o senhor rural. ${ }^{6}$

\footnotetext{
${ }^{4}$ MEIHY, op.cit.,

${ }^{5}$ FREIRE, Gilberto. CASA GRANDE E SENZALA. 51 ${ }^{\text {a }}$ Ed. Rio de Janeiro: Ed. Record, 1998

${ }^{5}$ VIANA CAMARGO, Rui Geraldo. A FAMÍLIA NA TRAVESSIA DO MILÊNIO. In: URL: http://www.buscalegis.ufsc.br/revistas/index.php/buscalegis/article/view/7513/7080, consultado em 18/03/09.
} 
As famílias com as quais nos deparamos nesta pesquisa diferem em quase todos os caracteres do modelo apresentado por Freyre: o traço que possuem em comum é serem extensas, não se restringirem ao núcleo “pai, mãe, filhos”. Nessas famílias não há a figura do patriarca, elas são chefiadas por mulheres separadas dos maridos, que sozinhas criam seus filhos; e não há também a propriedade da terra e da "casa grande”, o que há é a luta por moradia, e mesmo o terreno comprado por Maria da Paixão no sertão do Piauí, a casa que começou a construir para si, a casa que construiu para os pais, foram feitas com muito esforço.

O presente estudo compreende família como uma estrutura relacional composta por indivíduos que possuem vínculos afetivos e/ou biológicos entre si. Esses geram comprometimento mútuo, solidariedade, identidade de projetos de vida e propósitos em comum, embora esse comprometimento ou identificação nem sempre aconteçam de forma total, sem restrições, divergências e conflitos. Os vínculos que promovem o comprometimento entre os membros desse grupo tanto podem ser de ordem genética quanto simbólica. Há os "parentes de sangue” e os "parentes de coração", assim como há na sociedade os filhos biológicos e os filhos adotivos.

A falta de moradia, o elevado preço dos aluguéis ou a insegurança em habitar casa inadequada, feita com materiais precários ou construída em área de risco, são problemas que atingem a família como um todo, se não direta, ao menos indiretamente. Quem está seguro em sua casa própria ou alugada, teme pela vida dos familiares que residem em habitações menos seguras, por isso, a maioria das pessoas que conheci em ocupações de sem-teto, tanto em São Paulo como em Rondônia, estavam com suas famílias ou “dando um jeito” de trazê-la para perto. Os que estavam distante de parentes muitas vezes manifestaram a intenção de conseguir uma casa não apenas para si, mas para os familiares. Eram freqüentes histórias de filhas que "militavam” por suas mães quando estas não possuíam saúde suficiente para suportar os desconfortos da vida nos acampamentos, ou de irmãos mais velhos que lutavam para que os mais novos também possuíssem uma casa para morar.

Diante das muitas dificuldades que atingem as famílias de condição financeira baixa, redes de solidariedade são estabelecidas a fim de tornar suportáveis os desafios do cotidiano. Afinidades, preferências alimentares, origem, traços étnicos e uma "história parecida” podem promover a união de pessoas que não se conheciam antes de ingressarem nas periferias das cidades ou nos Movimentos Sociais, fazendo com que se considerem uma “grande família”. A partilha de uma mesma geladeira, de uma mesma 
fonte de água, de alimentos ou o zelo pelos filhos dos vizinhos, quando estes estão ausentes são alternativas criadas pelas famílias trabalhadoras para suprir a ausência do Estado.

"Sem-Teto", neste estudo, refere-se a pessoas que lutam por moradia, participação nas esferas política, econômica e cultural da cidade, ou “apenas” por participação nas esferas política, econômica e cultural da cidade. Trata-se de uma identidade em construção que, por um ângulo, transcende o "ter casa”, visto que algumas das pessoas que conheci no Acampamento Chico Mendes, em Porto Velho e no Acampamento João Cândido, em Itapecerica da Serra, possuem casa e apesar disso identificam-se como "sem-teto". Como exemplo, podemos citar um casal de aposentados que conheci na ocupação João Cândido, na Vila Calú (Itapecerica da Serra), mas que estava acampado desde o Valo Velho. Esse casal possui casa, mas depois de perder o único filho em um acidente de trânsito e passar um ano tomando remédios antidepressivos, resolveu alugar a casa onde morava e ir viver em um barraco de lona na ocupação acima referida. Essa mudança foi explicada por eles próprios como uma escolha identitária, que conferiu novo sentido a suas vidas. Apesar de não sofrerem “pessoalmente” com problemas como o habitacional ou o desemprego, se identificam com o sofrimento de outras famílias e decidiram apoiá-las, vivendo ao seu lado e as auxiliando-as na medida do possível, com a doação de sua força de trabalho para a manutenção do acampamento, doação de víveres e objetos de uso pessoal.

Ao tomarem contato com as dificuldades enfrentadas por famílias sem-teto que estavam acampadas no Valo Velho, esse casal conseguiu "sublimar" sua dor e canalizá-la para um projeto político que objetiva “o direito à terra urbana, à moradia, ao saneamento ambiental, à infra-estrutura, ao transporte e aos serviços públicos, ao trabalho e ao lazer, para as presentes e futuras gerações” ${ }^{7}$, ou seja, reforma urbana.

Não se trata, no caso apresentado, de pessoas oportunistas em busca de mais uma propriedade, e sim de pessoas com vivências singulares que em dado momento assumiram essa nova identidade a fim de expressar insatisfação com a ordem social estabelecida, com o descaso do Estado para com a classe trabalhadora e comungar com os que sofrem agudamente a espoliação urbana.

\footnotetext{
${ }^{7}$ Lei $N^{\circ}$ 10.257, de 10/7/2001 (Estatuto da Cidade). DIÁRIO OFICIAL DA UNIÃO, Seção I (Atos do Poder Legislativo). Edição No. 133, de 11/7/2001.
} 
Se em um primeiro momento a atitude do casal pode parecer um "ato desesperado" de busca de interlocutores para seu sofrimento, a permanência na ocupação João Cândido por mais de dois anos, a militância e a dedicação que conferem à luta organizada pelo MTST nos faz pensar que se trata de uma identificação não só com aquele Movimento, mas com a condição de ser sem-teto. Do contrário, poderiam ser apenas amigos do Movimento, visitar a ocupação eventualmente, depositar suas doações. Dizer "somos sem-teto, não queremos casa para a gente, mas queremos para os outros”, enunciado por um casal de terceira idade que não pretende se candidatar a nenhum cargo político nem assumir postos de liderança dentro da ocupação, não pode ser outra coisa senão expressão de uma “identidade de projeto", aquela quando os atores sociais, na base de quaisquer materiais culturais a eles disponíveis, constroem uma nova identidade que redefine sua posição na sociedade e, ao fazê-lo, buscam uma transformação global da estrutura social ${ }^{8}$.

Ressalvadas as devidas proporções, algo semelhante ocorreu na ocupação Chico Mendes, onde Carla, uma professora pós-graduada que possui casa própria em bairro enobrecido de Porto Velho, conviveu de modo intenso com trabalhadores semteto a fim de apoiar a luta por reforma urbana, que ela considera digna, bem como apoiar seus filhos e genros que foram para aquela ocupação em busca de terreno para construírem suas casas.

Quando nos referirmos a “famílias sem-teto", gostaríamos que o leitor tivesse em mente a questão habitacional enquanto problema que perpassa as gerações, que afeta a vida de pais, filhos, netos. Ressalta-se que nem todos os membros das famílias colaboradoras se identificam como sem-teto e participam do MTST ou do Movimento dos Trabalhadores Sem-teto de Rondônia. Mesmo para os que assumiram aquela identidade, é preciso dizer que ela está em processo de construção, que é conflituosa, amada e odiada, ora expressada com orgulho, ora com timidez. Essa identidade não impede que outras sejam também apresentadas, como a de homem, mulher, nordestino, amazonense e índio. Há graus variados de identificação com a idéia de "ser sem-teto" e com os Movimentos Sociais que lutam por moradia, sendo que para cada um desses graus correspondem discursos variados. Na história do projeto listarei o nome dos colaboradores que se apresentam como sem-teto e dos que não se apresentam e os leitores poderão conhecer maiores detalhes sobre seus posicionamentos e visões de

\footnotetext{
${ }^{8}$ CASTELLS, Manuel. O PODER DA IDENTIDADE. São Paulo: Ed. Paz e Terra, 2000.
} 
mundo na parte III, onde são apresentadas na íntegra as narrativas das histórias de vida de cada colaborador.

No Brasil, quem não possui residência fixa é visto, muitas vezes, como uma pessoa instável, “desenraizada” e pouco confiável. Recebe estereótipos como o de malandro, sujo, dissipador e vagabundo e é excluído de coisas "simples”, como o crediário de uma loja, matrícula escolar e o cadastro no "sistema” de um posto de saúde. Fica sujeito à violência policial e tem comprometido, pelo menos em parte, os sonhos, as lembranças, o “direito de sonhar”, pois a casa, com seu "ar” de intimidade e aconchego, seus cantinhos, gavetas e segredos é lugar propício ao sonho, às recordações e ao "arquivamento" de objetos biográficos, carregados de valor afetivo que se perderiam com maior facilidade em uma vida precária e nômade. O deslocamento constante, as incertezas quanto ao futuro próximo, a luta pela sobrevivência são atividades que consomem boa parte do tempo dessas famílias, tempo que poderia ser empregado em atividades mais prazerosas, como a narração de histórias, por exemplo.

O tema Memória recebe atenção especial nesta pesquisa porque é por meio dela que os colaboradores tecem suas narrações. Ela é concebida aqui como conjunto de impressões, imagens, lembranças e experiências recriadas pela linguagem. Não é fixa, monolítica, definitiva, mas encontra-se em constante elaboração. Concentra experiências oficialmente avalizadas, mas também experiências que fogem ao enquadramento do que é considerado oficial e digno de ser lembrado. Uma conversa informal, a aprendizagem de um conceito, um aroma ou sabor experimentado na infância, a necessidade afetiva de ser considerado no presente, de ser valorizado ou um acampamento destruído pela força policial, são vivências capazes de gerar uma memória específica e desencadear não só narrações das experiências vivenciadas, mas novo posicionamento ético e político frente ao mundo.

Como o ato de narrar é essencialmente relembrar e recriar experiências passadas atribuindo a elas novos sentidos, colorindo-as com a luz do presente, a Memória é elemento essencial para essa pesquisa e lança-nos vários desafios, dentre eles, perceber os elementos que se repetem nas narrativas constituindo uma memória coletiva, e fazer um estudo que leve em conta a “cidade da memória” desses colaboradores, ou seja, a cidade na dimensão que é entendida e narrada por eles, vivida e imaginada, e que ao mesmo tempo analise aspectos da cidade “real' onde esses trabalhadores sem-teto pelejam cotidianamente por sua cidadania. 
A cidade existe enquanto modo de produção, trabalho, lazer, mas também enquanto recordação de seus habitantes. As transformações pelas quais passou ao longo dos anos, as alterações em suas formas e relações, os objetos que desapareceram e os novos que foram postos em seu lugar fazem parte da memória dos citadinos e são retomados em suas narrativas. Nelas a memória é o local da cidade vivida e da cidade sonhada, onde o passado é visto como o "paraíso perdido”, tempo e lugar onde as coisas eram "mais harmoniosas"; ou como o "começo do problema”, o que fez as coisas ficarem como estão: desemprego ou subemprego, insegurança, desabrigo.

Na obra a Cidade Intencional, Lopes afirma que "terminou o tempo das cidades acidentais, que cresciam a partir de condicionantes diversos de uma sociedade mais crescente que organizada. O mundo de hoje exige a cidade intencional, em que o futuro é pensado e construído de forma organizada, participativa e planejada” ${ }^{9}$. Embora os ideais exigidos para a construção desse tipo de cidade ainda não estejam de todo presentes em nossa sociedade, especialmente o quesito "participação”, elas cada vez mais expressam, por meio de suas funções, que são cidades planejadas. Algumas se destacam por uma função especial que desempenham: a de pólo de concentração religiosa, médica, universitária. A busca por serviços médicos e educacionais oferecidos por determinadas cidades é justificada por sua excelência e pelo déficit na qualidade desses serviços em outras localidades; a procura por “cidades religiosas” se amplia à medida que “espaços sagrados” são inseridos na lógica do turismo, porém, é preciso destacar que toda cidade é múltipla e não se restringe a uma única função.

A cidade é por excelência o local da multiplicidade, das contradições, dos encontros e desencontros. Multiplicidade de pessoas, objetos, formas, crenças, identidades, fluxos, redes, gostos, anúncios, marcas, vestígios, estilos de vida e estilos arquitetônicos, tempos e temporalidades. Contradições entre periferia e centros, capital e trabalho, integrados e excluídos, barracos e mansões, patrões e empregados, celebridades e trabalhadores invisíveis, consumidores e pedintes, avenidas e becos, desperdício e carestia. Lugar onde esses elementos são mais visíveis e onde ocorre o encontro violento desses opostos, revelando que as coisas não podem continuar como estão, que o Político não pode continuar refém de um poder Econômico que beneficia a poucos.

\footnotetext{
${ }^{9}$ LOPES, Rodrigo. A CIDADE INTENCIONAL. Rio de Janeiro: Ed. Mauad, 1998.
} 
Em consonância com a história oral desenvolvida no NEHO/USP ${ }^{10}$, pautada nos princípios de colaboração, mediação e devolução ${ }^{11}$, que coloca a entrevista no cerne da pesquisa, esta dissertação foi organizada da seguinte maneira: Parte I - "História do Projeto”, que consiste em uma “descrição” de minha trajetória de vida e pesquisa, das etapas do projeto, de como foram realizadas as entrevistas e serão apresentadas nesse texto; também apresentamos “Considerações sobre o tema da pesquisa”, que introduz a reflexão sobre o eixo temático da pesquisa e seu corpus documental. Nela procuramos explicar como chegamos ao corpus documental da pesquisa, que será apresentado no capítulo seguinte e é o núcleo do trabalho. A Parte II é constituída pelos textos resultantes das entrevistas realizadas com os colaboradores da Grande São Paulo: Ana Terra, Tonho, Laura, Maria da Paixão, Luana, Cássio, Filipe, Marcos, Lady, Bárbara; e os colaboradores de Rondônia: Júnior, Carla, Caroline, Camila, Caio e Marcelo. A terceira parte: "Reflexões sobre a leitura em história oral”, trata da análise das narrativas apresentadas na parte três; a parte cinco traz algumas "Reflexões sobre o eixo da pesquisa”, em que se destacam memória, identidade, comunidade, os sentidos da propriedade, Movimentos Sociais e a luta na cidade. Na quarta parte, intitulada “Cartografias do Urbano”, discutimos questões como a produção e apropriação do espaço urbano e o MTST e a reforma urbana. Como alimentação é assunto tratado na maioria das entrevistas, decidimos trata-lo em um bloco específico: “Alimentação” e os significados da mística para os entrevistados. Finalmente, há as considerações finais sobre esta pesquisa, visto que é inviável falar de “conclusão” em se tratando de algo que ainda está em processo, como a luta dessas famílias por cidadania.

Entendemos que os desafios cidadãos enfrentados por essas famílias em seu cotidiano simbolizam uma luta por direitos humanos, da qual a Constituição Federal de 1988 é marco jurídico. Desse modo, o presente trabalho se inscreve não só no campo da história oral, mas no dos direitos do homem, adotando "a concepção contemporânea de direitos humanos, pela qual são concebidos como unidade indivisível, interdependente e inter-relacionada, na qual os valores da igualdade e liberdade se conjugam e se completam” 12

O acesso à moradia, saúde e educação compõe os chamados "direitos fundamentais”. Para que sejam assegurados faz-se necessária não apenas limitações que

\footnotetext{
${ }^{10}$ Núcleo de Estudos em História Oral da USP.

${ }^{11}$ Esses princípios serão discutidos na Parte I, no tópico "Os Procedimentos".

${ }^{12}$ PIOVESAN, Flávia. DIREITOS HUMANOS E O DIREITO CONSTITUCIONAL

INTERNACIONAL. São Paulo: Saraiva, 2009.
} 
inibam a interferência dos governos nos direitos civis e políticos, mas o cumprimento de obrigações governamentais em prol da promoção do bem-estar econômico e social, pressupondo um governo interventor, planejador e comprometido com os programas econômico-sociais da sociedade que, por sua vez, os transforma em direitos econômicos e sociais para os indivíduos ${ }^{13}$. Da efetividade dos direitos econômicos, sociais e culturais depende a efetividade dos direitos civis e políticos, assim como sem a realização dos direitos civis e político, ou seja, sem a efetividade da liberdade, os direitos econômicos, sociais e culturais permanecem apenas palavras. De acordo com Piovesan:

“Não há mais como cogitar da liberdade divorciada da justiça social, como também infrutífero pensar na justiça social divorciada da liberdade. Em suma, todos os direitos humanos constituem um complexo integral, único e indivisível, no qual os diferentes direitos estão necessariamente inter-relacionados e são interdependentes entre si."

Ressaltamos a historicidade desses direitos, seu caráter de constructo social, em constante processo de re-elaboração. Os direitos humanos são forjados no espaço concreto e simbólico das lutas sociais pela dignidade humana e justiça social.

\footnotetext{
${ }^{13}$ HENKIN, Louis. THE AGE OF RIGHTS. New York: Colúmbia University Press, 1990.
} 


\section{HISTÓRIA DO PROJETO}

Narrar a história desse projeto requer contar um pouco de minha própria, de minhas errâncias, dos caminhos que trilhei até chegar aqui.

Primeiramente quero dizer que este é “o meu caminho”, que não me arrependo de tê-lo percorrido porque amo aventuras e porque nesse caminhar, encontrei muitos parceiros de jornada que me ensinaram lições para a vida e me apresentaram novos horizontes. Com eles, foi fácil seguir adiante.

Em segundo lugar, quero dizer que apesar de essa narrativa tentar ser clara, coerente, direta, as experiências que vivi não foram bem assim. Os caminhos que segui foram sinuosos, muitas vezes sem sinalização e as escolhas que realizei nem sempre se deram com total consciência. O acaso me protegeu quando "andei distraída”, a sorte esteve presente em vários momentos, em outros se ausentou. Felizmente pude contar, ao longo de todo o percurso, com os conselhos de um sábio mestre, a saber, o professor José Carlos Sebe Bom Meihy.

Ainda não é o fim da aventura, é apenas o desfecho de uma primeira jornada, o momento de voltar para a casa. Fortuna lançou os dados e estes ainda estão rolando.

\section{Um pouco da trajetória}

Sou filha de mãe paranaense e pai paulista. Migramos para Rondônia em meados da década de 1980, com toda a minha família materna. Levamos na bagagem o sonho de uma vida melhor. Meus avós, agricultores de profissão, queriam um pedaço de terra para plantar, meus pais, uma casa na cidade, onde pudessem continuar exercendo os ofícios que aprenderam no Sul, e a família se uniu em torno desses projetos.

Cresci em Rondônia, entre o campo e a cidade, vendo as lutas de minha família e vendo crescer a especulação imobiliária nesses dois espaços. Não tinha a maturidade suficiente para interpretar aqueles processos e sequer conhecia o termo “especulação imobiliária”, mas as transformações na paisagem eram evidentes, e ora me alegravam, ora me entristeciam. Quando viajávamos de Ji-Paraná para Pimenta Bueno a fim de vermos nossos parentes, ficava encantada com os campos mecanizados, fazendo formas geométricas em tons degradê de verde, mas minha mãe, que já possuía sensibilidade de ambientalista, me perguntava sobre os passarinhos e onde eles botariam seus ovos. A empolgação com os campos se afastava e um "sentimento de nuvem", que agora decodifico como tristeza e preocupação, vinham tomar meus pensamentos de menina. Pela janela do ônibus ficava procurando os passarinhos e seus ninhos, e se localizasse algum, 
provavelmente essa seria a primeira notícia que daria a meus primos e primas quando chegasse a suas casas.

Conforme ia crescendo, crescia também o avanço das fazendas de gado, de café e posteriormente, de soja, bem como o avanço dos latifúndios urbanos. Esses últimos eram para mim, naquela época, apenas “terrenos baldios” onde eu não podia brincar porque havia o perigo de pregos enferrujados e cacos de vidro, que poderiam ferir meu pé.

No fim da adolescência, quando ingressei no curso de História da Universidade Federal de Rondônia, foi possível fazer outras leituras das problemáticas locais - que infelizmente não se restringem à região amazônica, apesar de assumirem características específicas naquele espaço. A partir do segundo semestre da graduação desenvolvi duas pesquisas, uma de iniciação científica denominada Espaço e Memória, que almejou compreender, por meio de história oral de vida de soldados da borracha ${ }^{1}$, a construção do Estado de Rondônia enquanto espaço social, e a outra, denominada Vozes do Silêncio: história oral com doentes mentais². Se o Tempo já era uma paixão em minha vida, com o projeto ${ }^{3}$ Nordestinos na Amazônia: a experiência de dois mundos, do qual Espaço e Memória é um desdobramento, uma nova veio se somar a ela: o Espaço. Meu encontro com a história oral, por meio das reflexões promovidas pelo Centro de Hermenêutica do Presente, das leituras do Manual de História Oral $^{4}{ }^{\mathrm{e}}$ finalmente, do diálogo pessoal estabelecido com o professor José Carlos Sebe Bom Meihy, por ocasião do IV Encontro Regional de História Oral que aconteceu em Porto Velho foi definidor do rumo que tomei.

Ao terminar o curso de História passei um semestre trabalhando em uma escola pública com EJA ${ }^{5}$ e em uma escola particular, onde ensinei História e História Regional para uma turma de cursinho pré-vestibular e uma oitava série do Ensino Fundamental. Com o fim do ano letivo, fui para São Paulo, onde fiquei seis meses realizando estágio no NEHO, a fim de aprender mais sobre história oral, memória, identidade e me preparar para a seleção de mestrado em História Social. Esse tempo que fiquei no NEHO estudando e participando das reuniões foi importante para aprofundar a reflexão sobre uma série de questões que compõem o conjunto de minhas preocupações intelectuais, e o fato de não ter me vinculado direto a nenhum curso oficial me permitiu flanar pela cidade e desejar conhecê-la cada vez mais.

\footnotetext{
${ }^{1}$ Esta pesquisa trabalhou com textos resultantes de entrevistas feitas com soldados da borracha que vieram do Nordeste brasileiro para a Amazônia no período da Segunda Guerra Mundial, quando então se travava a "Batalha da Borracha”.

${ }^{2}$ Realizei esta pesquisa para a obtenção do grau de Bacharel. Nela entrevistei homens e mulheres que estavam internados no setor de reabilitação psiquiátrica do Hospital de Base Dr. Ary Pinheiro, na cidade de Porto Velho.

${ }^{3}$ Projeto desenvolvido pelo Centro de Hermenêutica do Presente, na Universidade Federal de Rondônia, que a partir de entrevistas de história oral de vida, realizadas com soldados da borracha naturais do Nordeste e da Amazônia brasileira, procurou entender as experiências desses dois mundos e o que delas resultou.

${ }^{4}$ MEIHY, 1996, 2004 e 2005.

${ }^{5}$ Educação de Jovens e Adultos.
} 
Essas duas vivências: de estudo e de travessias levaram-me ao tema "história oral de uma família sem-teto de Taboão da Serra: memória e cidade”, que no desenrolar da pesquisa virou "história oral de uma família sem-teto da Grande São Paulo”, pois envolvia pessoas da cidade de São Paulo, Guarulhos, Itapecerica da Serra e Taboão da Serra. Posteriormente, por motivos de ordem familiar ${ }^{6}$ tornou-se "história oral de famílias sem-teto da grande São Paulo e de Porto Velho: memória e cidade”. Por sugestão da banca que examinou meu relatório de qualificação, o título foi novamente modificado, "Experiências de moradia: história oral de vida familiar”.

O adjetivo "sem-teto" foi retirado do título a fim de não limitar a leitura das histórias das famílias, de não reduzir a apenas um sentido a multiplicidade de suas experiências, contudo a noção de "sem-teto" foi utilizada em alguns momentos do texto, depois de "aparar suas arestas", ou seja, de contextualizar e explicar seu sentido. Não foi possível deixá-la de fora porque parte dos membros dessas duas famílias participam de Movimentos Sociais que trazem no nome a expressão "sem-teto" e lutam, nas fileiras desses movimentos por teto, trabalho, reforma urbana. A falta de casa, ou de casa adequada ${ }^{7}$, bem como as dificuldades em pagar o aluguel e os esforços para a construção da residência familiar são marcas importantes do percurso da vida e das narrativas das pessoas entrevistadas nesta pesquisa.

\section{A Escolha do Tema}

O eixo temático desta pesquisa: memória, família e cidade foi escolhido, entre alguns outros, levando em conta minha própria experiência e para especificar o critério das minhas escolhas, será apresentada em dois âmbitos: o familiar e o profissional. No que diz respeito ao primeiro, a escolha desse eixo temático se justifica por eu estar constituindo família e enfrentando dificuldades com relação à moradia; e no que toca ao âmbito profissional cabe destacar que como historiadora, me preocupo sobremaneira com os problemas de meu tempo. $\mathrm{O}$ problema habitacional - que é muito mais que um déficit na produção de moradias - em seu recorte espacial “acampamentos de trabalhadores sem-teto de Porto Velho/São Paulo” tornou-se um desafio de pesquisa, na medida em que transitava por esses dois mundos: Porto Velho, onde vive a minha família materna e São Paulo, onde vive minha família paterna. Penso que o meu "estar em movimento" favoreceu o contato com os dois grupos e a partir disso pude articular procedimentos para sua comparação e compreensão.

Para mim parecia claro e viável: a história oral possibilitaria o acesso às experiências de vida de duas famílias que lutam por moradia; o fato de eu morar em dois lugares me favoreceria

\footnotetext{
${ }^{6}$ Meu retorno a Porto Velho por motivo de casamento.

${ }^{7}$ Para a maioria das pessoas com quem conversei durante a pesquisa, “casa adequada” indica aquela onde se pode viver em segurança, com conforto, receber visitas e de onde se pode sair e entrar sem constrangimento.
} 
o trabalho de campo e a comparação, e o problema habitacional, por ser o elo que une inúmeras famílias em todo o Brasil a Movimentos Sociais que visam à construção e distribuição de casas populares - de modo imediato - e a reforma urbana, como ideal que perpassa todo o processo de luta, me pareceu pertinente para um estudo na área de História.

Entendo que a experiência de vida é um elemento importante na escolha dos temas, dos documentos, das metodologias e teorias utilizadas pelos historiadores no desempenho de seu ofício, e que negá-la ou ocultá-la implica em refutar a relação existente entre história e memória, a fim de salvaguardar uma pseudo-objetividade. Com relação a isso, Nora argumenta que:

\begin{abstract}
Toda uma tradição científica levou os historiadores, desde há um século, a apagarem-se perante o seu trabalho, a dissimularem a personalidade por detrás do conhecimento, a barricarem-se por detrás de suas fichas, evadirem-se para uma outra época, a não se exprimirem senão por intermédio de outros, permitindo-se fazer, na dedicatória da tese, no prefácio do ensaio, uma confidência furtiva. A experiência da historiografia pôs em evidência, há uma vintena de anos, os falsos aspectos dessa impersonalidade e o caráter precário de sua garantia. Também o historiador dos dias de hoje está pronto, ao contrário dos seus antecessores, a confessar a ligação estreita, íntima e pessoal que mantém com o seu trabalho. Ninguém ignora que um interesse confessado e elucidado oferece um abrigo mais seguro dos vagos projetos de objetividade. A explicação e a análise do investimento existencial, em vez de afastarem uma investigação serena, tornam-se o instrumento e a alavanca da compreensão ${ }^{8}$
\end{abstract}

Tenho uma relação estreita com meu tema e reconheço a necessidade de estudá-lo com um rigor que transcenda a paixão. Tratar da relação entre memória e cidade tendo por substrato a experiência de vida de famílias trabalhadoras em busca de um lugar na cidade requer cuidados especiais. Não se pode cair na tentação positivista de deixar os documentos falarem por si: as entrevistas são sedutoras, interessantes, comoventes e dão a dimensão do problema na medida apreendida pelos colaboradores, mas não o explicam de todo. Não se pode também cair na tentação de partir de uma teoria prévia para chegar a esse tipo específico de documento que são as histórias de vida, porque isso traria o risco de "esmagá-las”, torná-las "pequenas” ou mesmo “equivocadas".

Sabemos que é a pergunta que fazemos “que condiciona a análise e no limite, eleva ou diminui a importância de um texto"” e que o "problema epistemológico da história não é apenas um problema intelectual e científico, mas também um problema cívico e mesmo moral. O

\footnotetext{
${ }^{8}$ NORA, Pierre (org.) ENSAIOS DE EGO-HISTÓRIA. Lisboa: Edições 70, 1989, p. 9-10.

${ }^{9}$ BLOCH, Marc. APOLOGIA DA HISTÓRIA OU O OFÍCIO DO HISTORIADOR. Rio de Janeiro: Jorge Zahar Editor, 2001, p.8.
} 
historiador tem responsabilidades e deve prestar contas" ${ }^{10}$. Tive essas preocupações em mente quando decidi trabalhar com esse tema, escolhi-o por tocar a mim, diretamente, e por tratar-se de um problema social que necessita tanto de estudos como de políticas públicas direcionadas para a sua resolução.

\section{Os Procedimentos}

Esse texto foi escrito com a intenção de responder a três perguntas fundamentais quando se trabalha com história oral: 1) História oral de quem? 2) Como? 3) E por quê?

A resposta à primeira já pôde ser vislumbrado nas páginas precedentes. Fazemos história oral de duas famílias trabalhadoras, brasileiras, residentes uma em São Paulo e Itapecerica da Serra e a outra em Porto Velho. A primeira é a família da Laura, uma jovem que conheci na ocupação João Cândido do MTST, em Itapecerica da Serra. Laura e seu companheiro vivem naquela ocupação. A família de Laura, que também foi entrevistada mora no Jardim Ângela, em São Paulo. A outra família que colaborou com essa pesquisa é a família da Carol, jovem que conheci junto com seu noivo na ocupação Chico Mendes, em Porto Velho.

As entrevistas de história oral foram procedidas do seguinte modo:

a) Escolha da Colônia. Colônia é o grupo a ser estudado, neste caso, duas famílias que enfrentam dificuldades com relação a moradia e em alguma medida se relacionam com Movimentos Sociais como MTST e o Movimento dos Trabalhadores Sem-Teto de Rondônia.

b) Formação das Redes. Redes são subdivisões da colônia que indicam os critérios adotados para a escolha das pessoas a serem entrevistadas, tais como: faixa etária, sexo, gerações, grau de escolaridade, entre outros.

Nesta pesquisa trabalhamos com duas redes, uma constituída por colaboradores de Rondônia, outra por colaboradores de São Paulo. O “ponto zero” para a constituição dessas Redes em São Paulo foi a entrevista de Ana Terra, uma estudante de Biologia da Universidade de São Paulo, que possui bom relacionamento com a família do Tonho (esposo da Laura), um conhecimento orgânico sobre o MTST e a Ocupação Chico Mendes em Taboão da Serra, local onde viveu acampada. Em Rondônia, o “ponto zero” foi a entrevista do Junior, noivo da Carol. Ele me apresentou sua própria família para que eu a entrevistasse, mas por motivo de viagem dos seus pais e reclusão carcerária de seu irmão, não foi possível realizar tal tarefa. Diante disso, me apresentou à família de sua noiva e pude então prosseguir com a pesquisa. Não estabeleci o número máximo de pessoas que seriam entrevistadas assim como nenhum critério que limitasse a

\footnotetext{
${ }^{10}$ BLOCH, op.cit., p.17.
} 
participação de membros dessas famílias. Essas redes podem ainda ser organizadas em “subdivisões”, como a dos pais, dos filhos, dos casados e dos solteiros

Na subdivisão da rede dos pais podemos localizar as narrativas de Maria da Paixão que possui quatro filhas e três filhos, de Carla - que possui duas filhas e um filho, sendo que esse seu filho também possui um filho. Na subdivisão da rede dos filhos vamos considerar apenas aqueles que ainda não se reproduziram: Caroline, Luana, Rodolfo, Cássio, Laura, Filipe, Camila, Carol, Junior e Marcelo. Na subdivisão da rede dos casados consideramos tanto os que estão casados, como os que já o foram e estão “divorciados”: Maria da Paixão e Carla (divorciadas), Marcelo (divorciado), Laura e Tonho (casados), Caio (casado).

c) Pré-entrevista. Momento no qual se apresenta, em linhas gerais, o projeto de pesquisa para os colaboradores, se elucida os procedimentos, a necessidade de utilização de equipamentos eletrônicos para gravação de voz ou voz e imagem, bem como se agenda datas, horários e os locais onde serão gravadas.

d) A Entrevista, propriamente dita, é realizada com o consentimento do colaborador, e no caso deste projeto, que visa à subjetividade e as experiências de vida dessas famílias, não houve um roteiro de perguntas a ser seguido. Estas foram feitas na medida em que percebi necessário aprofundar alguma questão mencionada pelo narrador.

e) Transcrição. Este termo refere-se ao trabalho de passagem literal do oral para o escrito incluindo os “erros” de Português, repetições, gírias, expressões regionais e marcadores conversacionais que caracterizam a oralidade.

f) Textualização. Compreende o esforço de dar à entrevista um caráter de texto, fluido, inserindo perguntas e respostas em uma narrativa direta e que favoreça a leitura. Nesse momento, o que temos não são mais entrevistas, e sim textos abertos a múltiplas interpretações.

g) Conferência. Momento em que o pesquisador lê a narrativa resultante da entrevista para seu colaborador, a fim de receber autorização para seu uso, ou o entrega para que ele mesmo leia. O processo que compreende todo o conjunto de procedimentos, desde o projeto até a construção das leituras, é denominado Transcriação.

Para Caldas a totalidade do processo de construção de narrativas em história oral é denominada “Transcriação Hermenêutica” e indica uma “concepção e visão de mundo, não somente de como se produz um texto, mas sobre o fundamento da própria realidade e de como podemos compreendê-la e modificá-la”. ${ }^{11}$ Tal “concepção e visão de mundo” exige uma busca mais radical pelo colaborador e suas experiências, e à medida que nos vemos mais próximos dele, nos distanciamos do "tema” motivador da pesquisa. Isso ocorre porque ao nos colocarmos

\footnotetext{
${ }^{11}$ CALDAS, Alberto Lins Caldas. ORALIDADE, TEXTO E HISTÓRIA: PARA LER A HISTÓRIA ORAL. São Paulo: Ed. Loyola, 1999, p.74.
} 
em diálogo com o outro, vemos que ele extrapola com sua vivência qualquer categoria, rótulo, rede ou comunidade de destino ${ }^{12}$. Isso explica as mudanças de perspectivas desse estudo com relação a seus colaboradores. Se em um primeiro momento via-os como "sem-teto", visto participarem de ocupações do MTST e do Movimento dos Trabalhadores Sem-Teto de Rondônia, a aproximação e o diálogo que estabelecemos me fizeram entender como essa identidade é relativa e complexa, aceita por uns, rejeitada por outros e que, portanto, não pode ser usada como um enquadramento. Meus colaboradores, mesmo os que assumem a identidade de sem-teto, como a Bárbara e a Laura, por exemplo, são muito mais que isso.

A Transcriação corresponde ao trabalho de transpor em texto escrito o que foi dito verbalmente, mas não apenas o que foi dito "palavra por palavra”: é preciso incluir os significados dos gestos, das lágrimas, das pausas e mesmo o sentido que o narrador quis passar com determinadas frases ou reticências. Em um momento da entrevista da Laura ela disse: “minha mãe é...”, fez um gesto com os braços como querendo dizer: "não sei como caracterizala”. Como a entrevista foi gravada apenas em áudio, ficaria mais difícil para o leitor imaginar o que Laura diz dizer com aquele gesto. No momento da transcriação a solução que dei a ele foi acrescentar ao discurso de Laura: “Ela é evangélica, muito rígida em seus valores”, pois entendi que isso, somado à oração seguinte de Laura: “e eu não tinha muito juízo”, daria a dimensão correta do que Laura estava narrando: uma relação conflituosa com sua mãe no período da adolescência, cujo ápice foi a “surra” que levou. Dessa forma, transcriamos teatralizando o que foi dito, pois,

[...] recriando-se a atmosfera da entrevista, procura-se trazer ao leitor o mundo de sensações provocadas pelo contato, e como é evidente, isso não ocorreria reproduzindo-se o que foi dito palavra por palavra”. [...]. tem como fito trazer ao leitor a aura do momento da gravação. [...] O fazer do novo texto permite que se pense a entrevista como algo ficcional e, sem constrangimento, se aceita esta condição no lugar de uma cientificidade que seria mais postiça. Com isso valoriza-se a narrativa enquanto um elemento comunicativo prenhe de sugestões. ${ }^{13}$

A meta do trabalho transcriativo em história oral é comunicar bem: comunicar o sentido, a intenção, visto que o narrador não estará presente para explicar, “orientar” a leitura de determinados trechos de sua narrativa. De acordo com Barbosa, fazemos transcriação por que:

\footnotetext{
${ }^{12}$ BARBOSA, Fabíola Holanda. EXPERIÊNCIA E MEMÓRIA: A PALAVRA CANTADA E A PALAVRA CONTADA DE UM NORDESTINO NA AMAZÔNIA. São Paulo: FFLCH/USP, Tese de Doutorado, 2006.

${ }^{13}$ MEIHY, op.cit., p. 30-31.
} 
A “tradução" do oral para o escrito não se opera com uma simples transcrição, assim como uma tradução de idiomas diferentes, especialmente quando se trata de um texto subjetivo como a poesia e a narrativa do colaborador. Blanco, em espanhol, não se traduz para branco em português, simplesmente. Essa simples transposição de línguas gerou um texto conjunto de dois importantes poetas Otávio Paz e Haroldo de Campos: Transblanco (1986) e é de onde Meihy assimilou o conceito de "transcriação”. O poema é outro, e é o mesmo, a entrevista transcriada é outra e é a mesma. A transcriação nos aproxima do sentido e da intenção original que o colaborador quer comunicar. Essa história oral é, portanto, “comunicação em presença, a energia, o envolvimento multisensorial que inclui, entre outras, a categoria da fascinação” (Ferreira, 1997:66), da nostalgia, do idílico. E que precisam permanecer na escrita, quando já não existir mais “a presença”, “o diálogo”. ${ }^{14}$

A idéia de transcriação, entendida como aquilo que perpassa todo o processo de constituição das narrativas em história oral deu forma às histórias de vida que serão apresentadas neste trabalho, mas é preciso enfatizar que os princípios de Colaboração, Mediação e Devolução ${ }^{15}$ também estiveram presentes. Esses princípios estabelecem novo modelo de relação entre "pesquisador - pesquisado" (muitas vezes chamado de informante e depoente). De um modelo verticalizado, passa-se a um modelo de relação em estrutura horizontal, no qual os sujeitos envolvidos na pesquisa se relacionam de forma dialógica e se empenham em co-laborar para a construção de um registro de experiências e torná-lo público. Não se trata mais da relação sujeito-objeto, mas da relação sujeito-sujeito.

A Colaboração é o eixo dessa nova relação entre o pesquisador e aquele que narra suas experiências em entrevista, e altera de forma bilateral a posição tradicionalmente estabelecida entre os integrantes da pesquisa: “entrevistador" e "depoente, informante”, o que conduz e realiza a pesquisa e o que "presta uma informação", não participando de seu processo e não conhecendo seus resultados.

Com a Colaboração, o pesquisador toma para si a responsabilidade de ser o mediador da pesquisa, de ser aquele que busca as melhores condições para o diálogo, e o instiga com sua capacidade de ouvir, silenciar, perguntar. E o entrevistado deixa de ser simples informante ou “objeto de pesquisa” para ser o que trabalha junto, o que co-labora e.

Essas mudanças alteram também a noção de autoria, já que o trabalho foi desenvolvido pelas duas partes, que a experiência, o vivido, o lembrado, o imaginado, a história contada pertencem a um e as técnicas de registro e análise, a outro. Diante de tal problemática convencionou-se que o texto resultante de pesquisa em história oral é um texto de co-autoria, porém, que o diretor da pesquisa deve assumir as responsabilidades jurídicas sobre ele.

\footnotetext{
${ }^{14}$ BARBOSA, op. cit., p. 18.

${ }^{15}$ MEIHY, op.cit.
} 
O produto dessa relação não pode ser outro senão a devolução, o retorno do material produzido para os grupos ou indivíduos que trabalharam conosco na elaboração desse material o que representa também, um primeiro passo para uma história pública, que considera as experiências de uma coletividade e a expande para além dos muros da Academia.

Os procedimentos e princípios que apresentamos até o presente constituem um primeiro momento da história oral, o de constituição do "núcleo de documentação" que fundamenta o projeto. A segunda fase do trabalho é a analítica, e pode ou não ocorrer, dependendo do projeto. Nem sempre essa segunda fase é realizada, pois há projetos que não prevêem a análise das narrativas, preocupando-se somente com o registro e a formação de bancos de histórias.

Até aqui nos pronunciamos sobre as duas primeiras perguntas: história oral de quem e como? A partir de agora nos aventuramos a dissertar sobre a terceira, sobre porque escolhemos fazer história oral.

A razão dessa escolha é porque mediante a história oral podemos tomar conhecimento de vivências e saberes aos quais de outra forma não teríamos acesso, e justifica-se também pelo que ela tem de mais precioso: a subjetividade. Essa característica é o que a torna singular. De acordo com Portelli, o que a torna diferente é o fato de contar mais sobre "significados" do que sobre “eventos”16). O que as narrativas gestadas pela história oral “contam” diz respeito, principalmente, à subjetividade de seus narradores, à subjetividade do grupo do qual fazem parte, ao tempo em que vivem. São narrativas historicamente datadas e referenciadas em contextos sociais específicos, tecidas pela memória e pelo desejo, portanto, onde estão presentes não só "fatos históricos", mas também as fantasias, os sonhos, as mentiras, os silêncios e os esquecimentos. Essas narrativas não são o "acontecido", mas uma versão - nem melhor nem pior: única, - de vivências filtradas pela experiência e pelo tempo. Não são "relatos fiéis” do que se passou, de "como se deram as coisas”, mas um momento narrativo. De acordo com Barbosa:

\section{[...] aquilo que constituímos em entrevista colaborativa é a maneira como o colaborador está significando sua experiência, como ele simboliza sua vida, como lhe dá organização, naquele momento, naquelas condições específicas, onde e quando se deu a entrevista. Podendo, portanto se modificar, significar diferente; coisas que foram contadas de um jeito, serão contadas de outra maneira, ou mesmo omitidas. ${ }^{17}$}

Dessa forma, a discussão hoje, no campo dos historiadores, não é mais sobre a possibilidade ou impossibilidade de “controlar" a subjetividade das fontes orais, para se proceder

\footnotetext{
${ }^{16}$ PORTELLI, Alessandro. O QUE FAZ A HISTÓRIA ORAL DIFERENTE. Projeto História, São Paulo, n.14, fev. 1997, p.31.

${ }^{17}$ BARBOSA, op. cit., p. 26.
} 
a uma análise objetiva, pois o valor dessas fontes reside, não na imediata e verídica referência aos fatos, mas em suas interpretações ${ }^{18}$. Para Portelli,

\begin{abstract}
Não temos, pois, a certeza do fato, mas apenas a certeza do texto: o que nossas fontes dizem pode não haver sucedido verdadeiramente, mas está contado de modo verdadeiro. Não dispomos de fatos, mas dispomos de textos; e estes, a seu modo, são também fatos, ou o que o mesmo: dados de algum modo objetivos, que podem ser analisados e estudados por técnicas e procedimentos em alguma medida controláveis, elaborados por disciplinas precisas como a lingüística, a narrativa ou a teoria da literatura. ${ }^{19}$
\end{abstract}

Respondidas as perguntas, explicitados os procedimentos e situada a discussão no campo da história, gostaria de frisar como foi o processo de colaboração que gerou as narrativas com as quais trabalhamos nesta dissertação. Gostaria de dizer o que cada um fez a fim de deixar clara a forma como estou presente no texto.

Os colaboradores narraram suas histórias começando por onde quiseram, tiveram liberdade para parar quando sentissem vontade, refletir, comentar, “abrir parênteses”. Liberdade condicionada pela minha presença "estranha”, que intimida e instiga, e por todos os outros fatores de ordem objetiva e subjetiva presentes no momento da entrevista. É deles a "matéria" narrada: a experiência, a vida, as crenças, as concepções de mundo, as recordações e planos para o futuro.

A mim pertence o gravador, a habilidade em fazer o registro das histórias de vida e sua posterior análise $\mathrm{e}^{20}$. Coube-me ouvir, perguntar, respeitar as idéias e opiniões divergentes das minhas e transcriar nosso diálogo. Transcriar de modo a deixá-lo o mais compreensível possível para aqueles que não estiveram presentes em seu desenvolvimento, buscando o melhor sentido ${ }^{21}$, tornando-o mais favorável à leitura. Nessa busca por sentido e fluidez articulei ao discurso dos colaboradores os meus questionamentos, não em uma simples “anulação da minha voz”, em um desaparecimento, mas ao contrário, em uma "inclusão na dialogicidade do texto" ${ }^{22}$. Retirei o excesso de gírias de algumas narrativas, não por preconceito lingüístico, mas porque os próprios colaboradores pediram para eu "arrumar um pouco". Mantivemos o que consideramos importante para não descaracterizá-los.

\footnotetext{
${ }^{18}$ Ver ARRUDA, Gilmar. CIDADES E SERTÕES. Bauru: EDUSC, 2000.

${ }^{19}$ PORTELLI, Alessandro. A FILOSOFIA E OS FATOS: NARRAÇÃO, INTERPRETAÇÃO E SIGNIFICADO NAS MEMÓRIAS E NAS FONTES ORAIS. Tempo. Rio de Janeiro, v.1, n.2, 1996, p.59-72, p.64.

${ }^{20}$ Entendo que essas habilidades, outros também as possuem. Todos, potencialmente, podem fazer o registro de suas experiências e interpretá-las. Eu, enquanto historiadora, faço um tipo de registro e interpretação que considero "aceitável” tendo em vista os critérios apresentados que permitem considerar a relação instituída pela escrita histórica entre o vestígio representante e a prática representada; o que não quer dizer que outros também não possam fazer o mesmo.

${ }^{21} \mathrm{O}$ mais próximo àquele que o narrador expressou ou quis expressar.

${ }^{22}$ CALDAS, Alberto Lins. Caldas SEIS ENSAIOS DE HISTÓRIA ORAL. Caderno de Criação: UFRO/Centro de Hermenêutica do Presente, nº15, ano V, Porto Velho: junho, 1998, p.41.
} 
Iniciava o trabalho de transcriação das entrevistas logo após cada gravação, sem possuir ainda o seu conjunto e isso me fez perder algo importante: uma espécie de refrão que marca a memória coletiva da família da Laura. Esse refrão é: “E assim nós fomos convivendo”. Quando me deparei com a repetição dessa frase na entrevista de Laura, fiquei incomodada. Ela aparecia "fora de contexto": mesmo quando ela estava falando apenas de si, contando suas aventuras e desventuras, essa frase aparecia, no plural, marcando o fim e o início de um novo período. Minha atitude foi substituí-la por: “Assim nós fomos vivendo”, na esperança de que essa palavra suprimisse o problema...

Laura não estava equivocada. Mesmo quando não apareciam os “outros” na sua narrativa, eles estavam presentes, próximos e, portanto, não só viviam, como conviviam. A mesma frase apareceu outras vezes na história de vida de sua mãe e de sua irmã Luana e só então pude entender que expressava um estilo narrativo daquela família e também um modo de dizer que estavam juntos, que partilhavam das mesmas coisas, mesmo que fisicamente distantes uns dos outros. Mas também me fez pensar que naquela frase havia algo de “inevitável”, que não poderia ser facilmente mudado e que não se localizava no "pretérito perfeito”, num passado consumado, mas conservava um gerúndio, a idéia de continuidade, de movimento cíclico: “assim fomos convivendo” e “assim vamos convivendo”...

Depois de perceber meu erro, tratei de rapidamente concertá-lo e fiquei esperando que os homens da família também pronunciassem aquela sentença, o que não aconteceu. Talvez porque não conversamos o suficiente, porque não se deram conta dessa característica dos discursos de sua família e o incorporaram, ou porque não viveram e conviveram do mesmo modo.

\section{Caderno de Campo}

Tomei conhecimento da ocupação Chico Mendes de Taboão da Serra por meio de notícias veiculadas nos jornais e de meu amigo André, que na época também era estagiário do NEHO e tinha contato com pessoas de diversos Movimentos Sociais, dentre eles o MTST ${ }^{23}$.

Estive no acampamento Chico Mendes de Taboão da Serra apenas uma vez. Estada rápida, antes de ter projeto de pesquisa e estar no programa de Mestrado. Parei logo na entrada, na "portaria” e enquanto conversava com as pessoas que lá estavam, observava atentamente o mundo que se mostrava atrás delas: pessoas se movimentando em suas atividades cotidianas, uma cidade de lona ao lado de prédios abandonados antes mesmo de terem sido terminados, um morro com vegetação de reflorestamento, um terreno amplo onde se poderiam construir apartamentos para centenas de famílias sem-teto. Pensei nas pessoas que pagaram pelos

\footnotetext{
${ }^{23}$ Movimento dos Trabalhadores Sem-Teto. Foi esse movimento que organizou a ocupação do terreno no Jardim Helena, em Taboão da Serra.
} 
apartamentos e tiveram a obra embargada, mas que tem casa para morar ou tem condições de pagar um aluguel e nas que lá estavam naqueles pequenos barracos, que eram sua única possibilidade de abrigo e de “estar” na cidade.

Era por volta de onze horas, o sol já estava alto, o calor era intenso e imaginei como seria dentro daqueles barracos, não só a temperatura, mas a vida. Saí sem prosear com ninguém, apenas me apresentei ao pessoal da recepção como estudante de história e disse que voltaria outra hora. Passei três meses estudando para as provas do Mestrado, oficializando minha situação perante a Universidade de São Paulo e quando decidi voltar ao Chico Mendes, ele não estava mais lá. O terreno estava deserto e havia sinais de incêndio. Lonas pretas enrugadas, restos de madeira e de objetos domésticos compunham um cenário que até então só tinha visto em filmes e iconografias de guerras. Os comentários que ouvi na época é que não tinha sido um despejo, mas uma retirada pacífica após negociação favorável aos militantes e que ninguém havia se “ferido". Duvidei dessa última parte, pois deixar o lugar onde se viveu, abandonar objetos - que podem não ter grande valor comercial, mas que é o que se pode ter em uma vida precária e nômade - sair às pressas e ainda não para a casa desejada, só pode ser uma experiência de "fratura", de dor.

Parte das famílias daquela ocupação foi “contemplada” por um auxílio monetário para moradia, conhecido como "bolsa aluguel" e os que não receberam aquele benefício retornaram para a casa de parentes ou mesmo para as ruas e viadutos, migraram para outras ocupações de trabalhadores sem-teto na Grande São Paulo ou criaram uma nova: a ocupação João Cândido, em Itapecerica da Serra. Em um primeiro momento essa ocupação se concentrou no Valo Velho e depois, na Vila Calú, próximo ao Jardim Jacira, ao Jardim Ângela e ao Capão Redondo. Nessa ocupação, em Itapecerica da Serra, foi que comecei a participar: passei cerca de dois anos indo para lá praticamente em todos os finais de semana, a fim de desenvolver trabalho de campo e participar de algumas atividades do acampamento. Conheci pessoas admiráveis e fiz amigos muito especiais: Ana Terra, Silvana e Pascoal, Rodrigo e Fran, André (Mussa), Dona Maria, Seu Paulo, Seu Edson, Meg, Rose, Bárbara e Talita - que sempre me recebeu com muita generosidade em seu barraco - além, é claro, da família da Laura, que se tornou colaboradora desta pesquisa.

A primeira vez que fui para o acampamento João Cândido contei com a agradável companhia de minha amiga Cássia, pesquisadora do NEHO e também mestranda em História Social. Saímos do Largo da Batata, em Pinheiros, por volta das 14 horas e fazia muito calor. O ônibus era velho, de uma cooperativa que vive tendo problemas com as Prefeituras das cidades por onde circula. Gastamos quase duas horas para chegar lá e ainda tivemos que andar um trechinho a pé, mas nem notamos o tempo passar. Nesse dia, envolvida com a conversa nem 
reparei direito na paisagem daquela região, lembro apenas de uma "mata de eucalipto", que me chamou a atenção, de muitas casinhas bem próximas umas das outras, como é comum na periferia e de ter visto apenas duas escolas em todo o trajeto.

Cássia e eu perguntamos para várias pessoas que estavam em uma padaria e em uma quitanda onde ficava o acampamento dos trabalhadores sem-teto, e apenas uma pessoa soube dar as coordenadas para chegarmos até lá. Algumas pessoas se surpreenderam quando fizemos a pergunta, disseram que nunca tinham ouvido falar de uma ocupação do MTST no bairro. Quando lá chegamos e vimos cerca de 300 famílias acampadas, fui eu que fiquei surpresa com o fato de aquelas pessoas com quem conversei na Estrada de Itapecerica estarem tão próximas do acampamento e não saberem de sua existência. Estaríamos diante de um fenômeno de “invisibilidade social”?

O psicólogo Fernando Braga da Costa, quando desenvolveu sua pesquisa de mestrado ${ }^{24}$ afirmou que esse fenômeno diz respeito a uma percepção humana prejudicada e condicionada à divisão social do trabalho. Deixamos de enxergar a pessoa, de entendê-la como pessoa e percebemos apenas a função que desenvolve. O autor ressaltou que não se trata de um aspecto biológico da visão e sim de uma prática oriunda de um "fosso" entre as pessoas, resultante das diferenças de classes.

Ao que parece essa objetificação atinge não apenas garis e trabalhadores uniformizados, mas também trabalhadores sem-teto, empregados ou desempregados, que vestidos com roupas comuns, se mimetizam no restante do conjunto social. Por outro lado, esse "não enxergá-los" pode significar um "fechamento" dos que têm casa ao mundo ao seu redor. Talvez as pessoas com quem conversei façam apenas os caminhos "da casa para o trabalho e do trabalho para casa”, não tenham tempo de flanar pelo bairro onde vivem e observar a situação na qual se encontra.

A ocupação João Cândido fica em um morro, atrás de um campo de futebol de areia, que é muito importante para a vida do acampamento, pois é lugar de lazer dos que apreciam futebol, e é onde acontecem as grandes assembléias e comemorações. Quando os times não estão em campo, as crianças desenvolvem suas brincadeiras naquele espaço: casinha, pega-pega, bolinhos de terra e até futebol.

$\mathrm{Na}$ entrada do acampamento concentram-se os barracos das lideranças internas, dos coordenadores e a cozinha coletiva, onde uma senhora conhecida como "tia Maria” cozinha voluntariamente para as pessoas da ocupação. Ela cuida de dois netos porque sua filha, mãe dessas crianças, faleceu. É uma mulher risonha e caridosa que faz verdadeiros milagres, pois

\footnotetext{
${ }^{24}$ COSTA, Fernando Braga. GARIS: UM ESTUDO DE PSICOLOGIA SOBRE INVISIBILIDADE PÚBLICA. São Paulo: IP/USP, 2002.
} 
consegue, com o pouco de doações que chega, alimentar número grande de pessoas, que saem saciadas, elogiando seu tempero.

No primeiro barraco, do lado direito de quem está entrando moravam Rodrigo, Daniel e Gabriel, jovens do Movimento. No barraco havia uma mesa cheia de livros, uma cadeira com roupas e duas pilhas de colchões, disponíveis para quem precisasse pernoitar. Depois Rodrigo começou a namorar Fran, a população do barraco da moça aumentou e a dos rapazes diminuiu, mas sempre aparece algum convidado de outras ocupações que fica hospedado com eles. Daniel é estudante de História da USP e muito dedicado à militância.

A vez que dormi na ocupação foi no barraco da Fran/Rodrigo, em uma noite de sábado para domingo, porque fiquei para ajudar no sarau e não tive como retornar à casa de minha tia. Nesse sarau comemoramos seis meses da ocupação João Cândido. Rodrigo e eu transcrevemos diversos poemas de Fernando Pessoa, Carlos Drummond de Andrade, Bertold Brecht e de poetas do Movimento, fizemos um varal da porta da Ciranda até a entrada do pátio e os penduramos com prendedores de roupa, uma espécie de cordel. Cada pessoa que chegava podia ler e no final, pegar o que mais gostou e levá-lo para casa, como recordação. Fiquei fascinada com a maneira como as crianças daquela ocupação gostam de poesia e se interessam pela biografia dos poetas, coisa que quase não encontrava, por exemplo, nas escolas onde trabalhei.

Fran fez a abertura do sarau, convidou as pessoas a entrarem no pátio da Ciranda e se assentarem em poltronas imaginárias. Ela tem muito bom humor! A mística inaugural foi feita por Rodrigo e mais dois rapazes e consistiu em montar um barraco no escuro (as luzes foram apagadas), para relembrar as dificuldades do primeiro dia de ocupação, que aconteceu em uma madrugada em que havia chovido muito e até os gravetos que poderiam ser utilizados para fazer uma fogueira estavam úmidos e demoraram a ser acesos. Como finalização da mística foi acesa uma grande fogueira e nem precisamos mais da luz elétrica.

No sarau houve apresentações de músicas criadas pelas próprias pessoas do Movimento, como “O diabo é careta” e paródias de canções populares. Gostei muito de uma paródia feita por Luciano que ao invés de dizer: "Morena tropicana eu quero seu amor, ô ô ô", dizia: "Prefeito seu sacana dê o terreno do Calú, ô ô ô”. Esse sarau foi muito divertido, apesar de estar um pouco tensa por ter que “declamar” uma poesia. Na hora fiquei nervosa e não consegui lembrar, então fiz um pouporri de diversos fragmentos de poemas que me vieram à memória. Não consegui me lembrar de nenhum por inteiro.

As crianças fizeram uma ciranda e convidaram os adultos a entrar na brincadeira. Cantamos a música Cirandar, de Carlinhos Veloz e aquela melodia, as labaredas daquela fogueira iluminando o ambiente, os rostos de cada pessoa sorrindo na ciranda e as mãos das mulheres que seguravam com força as minhas, tudo isso me deixou muito emocionada. Senti 
como se estivesse revivendo uma experiência que estava esquecida e que só naquele momento recordei e compreendi. Falo de mística e solidariedade, de andar de mãos dadas, cantar cantigas de roda, ter um sonho coletivo, uma utopia, mas sem deixar de apreciar o agora, suas belezas e potencialidades.

Depois do sarau ainda ficamos conversado por umas duas horas: Aline - uma moça que estuda artes na ECA -, um senhor que fazia a ronda pelo acampamento e eu. Falamos sobre política e religião e como essas duas coisas conseguem co-existir na América Latina sem grandes conflitos, uma auxiliando a outra. Reportávamos-nos ao exemplo da Teologia da Libertação.

No dia seguinte, domingo, acordamos às sete horas, compramos pães e frios e tomamos café da manhã com as pessoas que apareceram no barraco da Fran. Em seguida houve uma briga de casal. Fran e a equipe de Disciplina tiveram que intervir. A mulher que apanhava do marido pegou uma bolsa de roupas, disse que era a última vez que apanhava e foi embora, o marido ficou conversando com a equipe, que sugeriu o divórcio a fim de parar com as brigas e o desgaste emocional.

O sarau foi uma experiência marcante, mas as que vivenciei nos dias que não eram de festa também o foram. Todas as vezes que estive na ocupação João Cândido aprendi alguma coisa nova ou conheci alguma pessoa que se tornou especial para mim. Nos raros momentos em que ficava sozinha aproveitava para faze anotações no caderno de campo.

Algo que me chamou a atenção no acampamento João Cândido foi a existência de tapetes do lado de fora das portas dos barracos, no chão de poeira. Esses tapetes se tornaram para mim símbolo do zelo, da organização, do desejo de estabilidade. Os barracos eram limpos, tinham tapetes nas portas, separando o que está fora do que está dentro. Entendi esses tapetes como uma zona liminar, de "purificação", de "limpeza” a fim de evitar a "contaminação" do interior dos barracos, de não alterar sua ordem. Tanto que em um dia posterior a uma tempestade, quando cheguei à ocupação e vi esses tapetes sujos de lama, rasgados e espalhados pelo acampamento, entendi que algo de grave havia acontecido e isso foi se confirmando à medida que caminhava entre os barracos: muitos foram destruídos pela chuva, outros estavam sendo reformados e não se falava de outra coisa senão do desespero daquelas horas de angústia e insegurança provocadas pela tempestade. Algumas mulheres ainda expressavam no rosto tristeza, preocupação e medo de o vento tornar a destruir seus barracos, deteriorar seus mantimentos ou amedrontar seus filhos. Conversei longas horas com Silvana sobre isso e à medida que ela ia narrando sobre as tempestades da sua vida, ficava difícil, para nós duas, conter a emoção e a revolta.

Outra coisa da qual me admiro é o zelo que pessoas como Silvana e Edson têm pelas hortaliças e flores. Apesar de a terra não ser muito fértil, construíram canteiros de verduras e 
jardinzinhos, que até a última vez em que lá estive, estavam muito bonitos, produzindo flores, como girassol, temperos, como coentro e legumes como abobrinha, pimentão e chuchu.

O barraco do senhor Edson é um primor e um dia almocei lá com ele e com a Meg. É um ótimo cozinheiro e me ensinou a fazer coxinha, fizemos umas cem para vender no dia da festa de comemoração dos seis meses da ocupação. Ele construiu em frente ao seu barraco uma mesinha e quatro banquinhos e os pintou de branco, plantou árvores e aquele lugar virou uma pequena praça. Como boa parte dos lugares públicos, este ficou sujeito a alguns mal-usos, então Edson resolveu dar-lhe um novo nome: de "Praça da República” virou "Praça da Independência” e não sei como, mas as pessoas começaram a respeitá-la. Talvez o termo "Independência” funcione como um alerta de que aquele lugar é uma propriedade privada, independente...

Apesar de levarem uma vida movimentada, com constantes deslocamentos em busca de emprego e moradia, de enfrentarem despejos e a incerteza quanto aonde ir, essas pessoas levam consigo objetos biográficos, como anéis, álbum de fotografias e pequenos objetos decorativos. Ana terra leva em seu corpo o anel de coquinho que ganhou de seu amigo do MST, anel que simboliza sua aliança com o povo pobre. Bárbara guarda sobre a penteadeira, seu book que bem poderia ser enviado a alguma agência de modelo. Filipe "não tira da cabeça” o boné azul de sua “gang”, que o identifica com a comunidade do Capão Redondo, onde vive há mais de 12 anos. Laura expõe em sua sala, que é simultaneamente quarto e cozinha, um cilindro de bambu com uma personagem de anime entalhada. Essa peça foi trabalhada por um amigo dela, que disse que a garota representada se parece com ela. Laura não concorda com a semelhança que o amigo atribui: a personagem é Serena, uma garota loira de um desenho japonês chamado Saylor Moon, no entanto, Laura cuida com carinho daquele objeto porque ele o faz recordar de seu amigo e do tempo de sua infância. Em artigo publicado na revista Oralidades ${ }^{25}$, no qual refletimos sobre o valor dos objetos biográficos e das performances narrativas na construção da história oral de vida, o conceituamos “como construções do mundo material sobre os quais são projetadas experiências de vida do seu possuidor” Eles catalizam memórias que estimulam performances narrativas, favorecem a narração, e por isso, é recomendável que lhes prestemos atenção de modo especial durante o trabalho de campo e que perguntemos sobre eles para nossos colaboradores.

Alguns barracos possuem cercas de bambu ao redor, com altura de 40, 50 centímetros aproximadamente. Pensei a princípio que fosse para assegurar a propriedade, mas logo entendi que aquelas cercazinhas não asseguram nada além do cuidado e da preocupação estética de seus moradores. Todavia, elas podem significar também “reprodução” do que se passa nos bairros da cidade e mesmo nos sítios: a cerca para separar e assegurar a posse de algo.

\footnotetext{
${ }^{25}$ BARBOSA, Xênia de Castro. PERFORMANCE E OBJETO BIOGRÁFICO: QUESTÕES PARA HISTÓRIA ORAL DE VIDA. São Paulo: NEHO/USP, Ano 1, vol. 2, Jul-Dez/2007, p.101-110.
} 
A infra-estrutura do acampamento João Cândido é para mim um tanto precária. Água só vem na parte da manhã, as torneiras são coletivas, então os acampados precisam baldeá-la para seus barracos. Alguns tambores são cheios diariamente e servem como reservatório. Existem cinco pias de uso coletivo, banheiros e também uma cozinha coletiva, onde as pessoas podem cozinhar ou pegar algum alimento e levar para complementar sua refeição nos barracos. O acampamento conta também com a Ciranda, espaço onde as crianças brincam e desenvolvem atividades pedagógicas, coordenadas por professoras voluntárias.

Em termos religiosos, o Movimento se pronuncia permitindo que as pessoas freqüentem a igreja que quiserem, mas não autoriza a realização de cultos e pregações dentro do acampamento. Há muitos evangélicos, mas há também católicos e ateus. A relação com a Igreja Católica é bastante amistosa. O pároco da região abastece o acampamento com água e seus paroquianos frequentemente fazem doação de alimentos, produtos de higiene e roupas às famílias daquela ocupação. Padre Alberto Gambarini, da Igreja Nossa Senhora dos Prazeres, foi uma figura importante na mediação entre as pessoas do Movimento, a Polícia e os Vereadores de Itapecerica da Serra, por ocasião do primeiro ato na praça daquela cidade. Trabalhadores semteto ficaram por mais de dez dias acorrentados em frente à igreja de Nossa Senhora dos Prazeres, que se localiza ao lado da Câmara Municipal de Itapecerica da Serra. Esse acorrentamento foi um protesto contra a ordem de despejo do terreno ocupado na Vila Calú e em prol da construção de moradias populares para atender a população necessitada da região.

A ocupação João Cândido, em seu primeiro momento, no Valo Velho, reuniu cerca de 2.500 famílias, em torno de 5.000 pessoas, mas quando se deslocou para a Vila Calú, apenas 250 famílias permaneceram. De acordo com Fran, que em 2007 era coordenadora interna dessa ocupação, essas 250 famílias que permaneceram eram "as mais necessitadas, as que realmente não tinham para onde ir”. Ela elaborou um recenseamento das famílias, priorizando a permanência das que possuíam mais filhos em idade escolar. Não tive acesso a esses documentos porque na época eles não estavam mais com a Fran, mas ela comentou em sua entrevista que havia 100 crianças naquela ocupação e que, portanto, a existência da Ciranda era indispensável.

Já a ocupação Chico Mendes de Porto Velho ${ }^{26}$ teve estrutura e duração menor. Ela se localizou na Estrada da Penal, entre uma Cerâmica e uma antiga ocupação de trabalhadores semteto, que agora apresenta características de bairro: ruas pavimentadas, água encanada, energia elétrica, casas reformadas, escola. Essa ocupação já passou por quatro ou cinco despejos ${ }^{27}$ e há divergências com relação à demarcação do terreno que ela ocupa e a quem ele pertence. De acordo com os advogados que cuidam do caso em prol das famílias que lutam por moradia, trata-

\footnotetext{
${ }^{26}$ A ocupação organizada pelo MTST em Taboão da Serra também tinha esse nome. Nas duas cidades: Taboão e Porto Velho, ele é uma homenagem ao líder ecologista que trabalhou nos seringais do Acre e defendeu a Amazônia frente aos interesses internacionais.

${ }^{27}$ Há essa divergência de quantidade na memória coletiva das pessoas do lugar.
} 
se de área rural na fronteira do perímetro urbano que foi vendida ilegalmente, enquanto que o INCRA deveria tê-la doado à Prefeitura, já que é um imóvel de interesse público praticamente dentro da cidade (ocupado por citadinos). O dono da cerâmica contesta e as metragens realizadas pelos agrimensores da Prefeitura de Porto Velho e do Movimento apontam para um deslocamento do marco da propriedade da cerâmica, “uma invasão sobre a terra dos sem-teto”. Enquanto o processo judicial tramita, os trabalhadores despejados aguardam a resolução do problema, esperançosos de que a Prefeitura atue de modo favorável a eles.

Diferente das ocupações que conheci em São Paulo, essa possuía em vez de barracos de lona próximos uns dos outros, barracos feitos de madeira e cobertos com palha de coqueiros, distantes uns dos outros, cada um em seu quintal; os barracos de lona eram minoria. Muitos não possuíam porta, janela e nem paredes. Eram apenas cobertos com palhas ou telhas velhas e seus donos pareciam não se incomodar com o fato de não ter paredes. Repousavam em suas redes, cozinhavam ou namoravam sem se importar com os vizinhos ou a pesquisadora que os observava, tentando evitar a indiscrição. Penso que o comportamento desses trabalhadores deva ser entendido como expressão de uma cultura amazônica, acentuadamente indígena e cabocla.

Havia também alguns terrenos reservados para a construção de igrejas pentecostais, que promoveram grande polêmica. Alguns diziam que os evangélicos estavam se aproveitando da situação, pois ao fincar no terreno uma placa com nome de determinada denominação religiosa intimidava as pessoas que realmente precisavam de um terreno para construir suas casas. Nem era preciso militar ou cuidar do terreno, pois a placa já o assegurava, a final, ninguém se sente à vontade em “tomar algo que é para a obra de Deus”. Os ateus, entre outros, se posicionaram contra a construção de qualquer igreja naquele lugar e afirmaram que se isso acontecer, não se vai poder proibir a edificação de bares ou prostíbulos.

A maioria dos terrenos possuía placa indicando o nome da pessoa que o ocupou ou simplesmente indicando que "tem dono", mas terrenos que não possuíam barraco ou que não eram mantidos limpos (roçados, capinados), bem como os que seus “donos” não participavam das reuniões ou quase não apareciam, costumavam sofrer novas ocupações. A delimitação dessas datas também foi conflituosa: cercas foram construídas entrando na "propriedade" do vizinho e até barracos foram construídos tomando parte em lotes alheios. A resolução desses conflitos ora se dava de forma amistosa, mediante negociação entre os envolvidos, ora se complicava e exigia a mediação das lideranças do Movimento. Presenciei brigas e ameaças de morte e soube que certa vez até a Polícia foi chamada para apartar a briga entre duas mulheres.

Poucos barracos foram construídos e não havia mais que 50 famílias participando dessa ocupação, ou seja, aproximadamente 250 pessoas, mas apenas uma minoria se envolveu efetivamente com os trabalhos do Movimento e a organização do acampamento. Ao lado dessa 
ocupação, separada apenas por um caminho estreito, havia outra ocupação, anterior a essa que já possuía inclusive luz elétrica e pequenas casas de alvenaria, mas as pessoas do "lado de lá” se recusavam a se unir com as da ocupação Chico Mendes, embora não negassem auxílios pontuais às famílias necessitadas do terreno ao lado, como o fornecimento de água, por exemplo.

Somente quando veio a ordem do despejo os integrantes dessas duas ocupações resolveram se unir e reconhecer que estavam "na mesma situação". Lembro de ter ouvido uma mulher dizer: “o que separa a gente é só uma rua”. No dia que estava previsto o despejo fui para lá cedo, sem saber de nada e minha colaboradora Carolina veio correndo me mostrar o papel que a Polícia havia entregado nos barracos. Pouco depois chegou Marinete, a coordenadora da ocupação e um senhor de idade com um menino, que vieram trazer um mapa e uma carta do terreno. O que Marinete dizia e apontava no material cartográfico trazido por aquelas duas pessoas era que a ordem de despejo havia sido entregue em lugar errado, que não era para a ocupação Chico Mendes, mas sim para as pessoas da ocupação ao lado. Disse que tinha acabado de voltar do escritório do advogado e que este iria comunicar o “equívoco” ao Ministério Público e que se a Polícia viesse fazer o despejo, era para as famílias resistirem e pedir pra que esperassem o advogado. Nesse dia as duas ocupações estabeleceram um consenso, organizaram suas estratégias de protesto e resistência, coletaram madeiras e pneus velhos para erguer as barricadas, mas infelizmente também nesse mesmo dia a Polícia colocou tudo a baixo, inclusive as casas de alvenaria que lá estavam a mais de dois anos.

Senti-me mal - era o penúltimo mês da minha gestação - fui para o hospital verificar a pressão e os batimentos cardíacos da minha filha, depois voltei para casa e fiquei me comunicando com Marinete, Carolina e outros amigos daquela ocupação por telefone. Não pude voltar para lá. De noite Marinete me telefonou pedindo para que eu chamasse algum de canal de televisão para fazer uma reportagem sobre o protesto organizado pelas famílias. Meu esposo e eu tentemos telefonar para uns jornalistas amigos da mãe dele, mas não atenderam, então fomos a sede de dois canais de TV fazer o que Marinete solicitou.

Os despejos, protestos, resistências são elementos que marcam as ocupações estudadas em Porto Velho e Itapecerica da Serra, mas há que destacar também seus pontos de diferenciação. Um deles, no que diz respeito à estrutura dos acampamentos, é que o do Chico Mendes, em Porto Velho possuía ruas mais largas e aplanadas, abertas por tratores e cada uma dessas ruas era uma homenagem a algum soldado da borracha, parente ou conhecido dos militantes. Em cada uma havia uma plaquinha confeccionada artesanalmente pelos moradores e futuros moradores daquela rua - muitos não construíram barraco, pois aguardavam a construção de casas populares pela Prefeitura, mas iam para lá com freqüência e zelavam pelo terreno onde gostariam de ter sua casa construída. A idéia de homenagear os parentes mortos na Batalha da 
Borracha foi idéia de Carla, uma de nossas colaboradoras. Carla circulava com destreza por entre o acampamento, tendo sempre sua bolsa elegante à tira-colo, sua pasta cheia de papéis e prancheta com bloco de anotações. Ela era chamada de "professora" e gozava do respeito e admiração da maioria.

Outro aspecto de diferenciação entre os acampamentos é que no de Porto Velho havia uma cratera resultante do trabalho de extração de argila da Cerâmica, que se tornou uma represa, onde as crianças e jovens costumavam brincar e tomar banho. Nas margens dessa cratera havia algumas árvores nativas da Amazônia e este era o único espaço com vegetação, pois o restante do terreno era um descampado. Havia apenas uma outra árvore, cuja sombra me servia de abrigo para preparar o material da pesquisa (caderno de campo, gravador, câmera fotográfica), ou para descansar nas horas em que Sofia começava a ficar inquieta no meu ventre. Ao redor dessa árvore fizemos muitas reuniões e nos confraternizamos, comendo bolos e chupando geladinhos ${ }^{28}$ que algumas pessoas do Movimento levavam para vender em caixas de isopor.

Na maioria das vezes era esse clima de confraternização e amizade que prevalecia, mas a ocupação de vários terrenos por pessoas de uma mesma família promoveu muitas discussões e ressentimentos. Marinete e Loura, as mulheres que lideravam a ocupação temiam a especulação imobiliária, a venda de terrenos e os problemas que isso poderia gerar, mas as pessoas que “reservaram” para si vários lotes justificaram tal atitude com um discurso de preocupação com o bem-estar da família e o desejo de tê-la próxima e unida, o que segundo eles seria mais fácil se todos tivessem sua casa e morassem próximos. A família apareceu nas entrevistas que realizei e mesmo nas conversas informais como a "razão de ser" da luta e o motivo pelo qual não desanimavam frente às dificuldades. Família e casa aparecem relacionadas: quem tem família deseja uma casa e quem quer formar família entende que primeiro é preciso ter casa e emprego.

Gravei ao todo 24 entrevistas de história oral com participantes do MTST e do Movimento de trabalhadores sem-teto de Porto Velho. Muitos deles membros de uma mesma família, mas o próprio processo de luta e as configurações que esses movimentos foram assumindo levaram alguns desses militantes a romperem relação com esses Movimentos, o que fez com que alguns deles me procurassem e pedissem para que eu não usasse suas entrevistas, pois não gostariam mais de ter seus nomes vinculados a essas expressões de luta. Os pedidos foram aceitos, algumas entrevistas foram refeitas de acordo com a vontade dos colaboradores e outras abandonadas. Sobraram 16 que considero suficientes para o desenvolvimento desse trabalho, não só pela quantidade, que possibilita comparações e cruzamentos, mas pelo seu conteúdo e significado social.

\footnotetext{
${ }^{28}$ Suco de frutas ou leite com chocolate congelados em pequenos sacos plásticos.
} 
Os colaboradores que não possuem casa e se identificam como sem-teto são: Laura, Tonho, Marcos, Lady, Bárbara; os que não possuem casa, não se apresentaram como sem-teto mas estão envolvidos com a luta de Movimentos Sociais por moradia são: Caio, Carolina, Camila, Cássio, Marcelo; os que possuem casa (própria ou alugada) são: Carla, Maria da Paixão e seus filhos Filipe (22 anos), Luana (11 anos), Caroline (3 anos) -Filipe, Luana e Caroline moram com a mãe; os que possuem casa (própria ou alugada), mas se identificam com o projeto de seus familiares junto aos Movimentos Sociais citados são: Carla e Luana. 


\section{CONSIDERAÇÕES SOBRE O TEMA DA PESQUISA}

O tema desta pesquisa é memória, família e cidade, assuntos que estão sendo discutidos por diversas áreas do conhecimento, como Arquitetura, Sociologia, Antropologia, Urbanismo, Geografia e História. No campo da historiografia os temas família, cidade, memória receberam destaque a partir das primeiras décadas do século XX, com a Escola dos Annales, embora já na segunda metade do XIX estudiosos como Johan Bachofen e Friedrich Engels tenham publicado, respectivamente: “O Direito Materno” (1877), “Origem da Família, da Propriedade Privada e do Estado” (1884). O objetivo desses autores, que escreveram em um período marcadamente racionalista, positivista e crítico às ideologias religiosas, era apresentar de forma literária os modelos de família anteriores ao vigente em sua época: patriarcal, burguês e cristão, dominado pela figura do pater famílias. Essa família tinha a propriedade como um de seus pilares e objetivava demonstrar seu caráter de construção histórica, portanto, passível de ser superado. A produção historiográfica realizada pela Escola dos Annales, desenvolvida em outro contexto e motivada por outros fatores, dentre eles a necessidade de combater uma história essencialmente política e diplomática, que tinha como sujeitos apenas reis, presidentes e generais, passou a ampliar o leque de objetos e temas que poderiam ser trabalhados pela historiografia. Foi neste contexto que a família, a memória, as lutas sociais e o espaço entraram em cena como desafios cognitivos ao historiador.

No Brasil, a abordagem teórica recente do tema “família” (dos anos 1980 para cá), tem se conduzido para pelo menos três direções: a) uma que privilegia análises quantitativas de seu desenvolvimento; b) uma que a partir de narrativas de família analisa os impasses relacionados à imigração $^{29}$ e os desafios culturais impostos pela vida na nova sociedade; c) e uma que destaca o papel da mulher na família e no povoamento, com ênfase nas discussões de gênero e poder. ${ }^{30}$ Não poderia deixar de destacar o trabalho de mestrado de Suzana Lopes Salgado Ribeiro: “Processos de mudança no MST: história de uma família cooperada”, que abriu o caminho para que reflexões semelhantes fossem elaboradas no âmbito da história oral e dos demais Movimentos Sociais; e a obra “Família, Mulher, Sexualidade e Igreja no Brasil”, organizada por Maria Luiza Marcílio ${ }^{31}$. Essa obra relaciona à família a Igreja e a sexualidade, analisando o papel normatizador e controlador do casamento e das instituições, como a família e a Igreja.

\footnotetext{
${ }^{29}$ Destacam-se os trabalhos de Samira Adel Osman: CAMINHOS DA IMIGRAÇÃO ÁRABE EM SÃO PAULO HISTÓRIA ORAL DE VIDA FAMILIAR, e o de Sônia Novinsky: AS MOEDAS ERRANTES - NARRATIVAS DE UM CLÃ GERMANO JUDAICO CENENÁRIO.

${ }^{30}$ Família, Mulheres e Povoamento (EDUSC, 2003), e As Mulheres, o Poder e a Família (Marco Zero, 1989), são paradigmáticos nesse sentido.

${ }^{31}$ MARCílIO, Maria Luiza. FAMÍLIA, MULHER, SEXUALIDADE E IGREJA. São Paulo: Ed. LoyolaCEDHAL, 1993.
} 
O tema “cidade” e a produção de seus espaços em tempo de globalização foi assunto discutido na obra de Milton Santos, que além de nos mostrar as metamorfoses do espaço que habitamos, questiona as estruturas de poder que estão em jogo em sua produção e instiga-nos a lutar por uma outra globalização ${ }^{32}$. A cidade de São Paulo e sua região metropolitana, especificamente no que diz respeito à questão habitacional, foi estudada pela geógrafa e urbanista Céline Sachs ${ }^{33}$ e no que diz respeito ao crime e à segregação espacial, o livro de Teresa Caldeira $^{34}$ é um dos cânones no assunto.

Violência e segregação espacial, assim como a existência de milhares de famílias semteto constitui a "outra face” do processo de crescimento econômico do Brasil. A maneira como esse processo foi conduzido, concentrando a renda nas mãos de uma parcela pequena da população e afastando sua maior parte da definição e administração das políticas referentes ao urbano, desencadeou um processo que ecoa na discussão em torno da reforma urbana e envolve “segmentos sociais antagônicos, portadores de compreensão e discursos diferentes sobre a cidade" 35 . Com o objetivo de estabelecer diretrizes federais para a política urbana o Congresso Nacional aprovou em 2001 o Estatuto da Cidade ${ }^{36}$, que além de regulamentar os artigos 182 e 183 da Carta Magna dispõe instrumentos jurídicos de controle da especulação imobiliária e de atenuação das demandas sociais até agora não satisfeitas.

A despeito de todas as reivindicações da sociedade civil e de ações pontuais do Estado sobre problemas que no clímax de sua vitalidade assomam à nossa realidade e permanecem insanáveis, o que se destaca é um vazio institucional, tanto no que se refere aos poderes estatais quanto às instituições assistenciais, que tem pouca atuação junto a essas famílias, realizando, quando muito, apenas atividades assistencialistas que, embora sejam válida como ação paliativa, são incapazes de resolver a essência do problema. Yara Ataíde argumenta:

Há uma reconhecida falta de vontade política do Estado e dos grupos que estão no poder em investirem esforços e recursos na proteção das classes populares em situação de pobreza extrema e desemprego. Em contrapartida, são comuns os incentivos e o apoio a grandes produtores, banqueiros, empresários e empreiteiros que dominam a economia do país,

\footnotetext{
${ }^{32}$ SANTOS, Milton. POR UMA OUTRA GLOBALIZAÇÃO: DO PENSAMENTO ÚNICO À CONSCIÊNCIA UNIVERSAL. São Paulo: Ed. Record, 2000.

33 SACHS, Céline. SÃO PAULO: POLÍTICAS PÚBLICAS E HABITAÇÃO POPULAR. São Paulo: Ed. EDUSP, 1999.

${ }^{34}$ CALDEIRA, Teresa. CIDADE DE MUROS: CRIME, SEGREGAÇÃO E CIDADANIA EM SÃO PAULO. SÃO PAULO: ED. 34/EDUSP, 2000.

35 SILVA, José Borzacchielo da. O ESTATUTO DA CIDADE E A REFORMA URBANA NO BRASIL. São Paulo: Ed. HUMANITAS (GEOUSP - ESPAÇO E TEMPO, vol. 10), 2000, p. 10.

${ }^{36}$ Lei 10.257 de 10 de julho de 2001.
} 
juntamente com aqueles que detêm o poder de organizar lobbies e compor alianças com os grupos da cúpula política. ${ }^{37}$

A maioria da população brasileira mora em cidades, particularmente nos grandes centros urbanos $^{38}$ e seus problemas e possíveis soluções mantêm-se paralelos aos do campo. Por isso não surpreende que um Movimento Social do porte do MST reconheça a cidade como um espaço também de luta, perceba a legitimidade das reivindicações dos citadinos e a necessidade de ele próprio contribuir com seu aporte para a formação de Movimentos Sociais urbanos.

O tema da memória está presente tanto nas discussões dos historiadores: o que é memória e o que é história, e como a primeira pode ser fonte para a segunda, quanto na própria escrita da história. Falar do estudo da História implica também em dissertar sobre a origem da memória, do testemunho, da pergunta e da resposta, elementos constituintes da historiografia clássica, que foram amplamente utilizados pela historiografia medieval e tiveram, no século XVIII, uma interrupção devido o império do Racionalismo iluminista e posteriormente, do Positivismo. Este conferiu à História o status de ciência, sistematizou seus métodos e colocou em dúvida os relatos da memória, visto que esta é construção subjetiva, e portanto, foge aos domínios da racionalidade. No Brasil, a memória enquanto substrato para o estudo das cidades, de suas transformações e das características psicológicas dos grupos que as promoveram tem dois referencias teóricos que merecem destaque: Memória e Sociedade ${ }^{39}$, no campo da Psicologia Social, e O Imaginário da Cidade ${ }^{40}$, texto que se insere no quadro da Nova História Cultural, e a partir da literatura, entendida como forma de representação do passado, revela a construção de um imaginário da modernidade urbana, remetendo-nos a temporalidades distintas, que percorrem Paris, Rio de Janeiro e Porto Alegre, indo do final do século XVIII às duas primeiras décadas do $\mathrm{XX}$.

É grande o número de pesquisadores empenhados no estudo das questões que preocupam esta pesquisa e existe vasta literatura sobre esses assuntos, mas na maioria das vezes foram tratados de forma separada: ou memória, ou família, ou cidade. Até o presente desconhecem-se pesquisas que tenham refletido sobre estes temas a partir destas “colônias”: famílias em busca de

\footnotetext{
${ }^{37}$ ATAIDE, Yara Dulce Bandeira. CLAMOR DO PRESENTE. São Paulo: Ed. Loyola, 2002, p. 234.

${ }^{38}$ De acordo com a contagem do IBGE de 2000 mais de 78\% dos brasileiros moram em cidade. Ver site do instituto: (URL http://www.ibge.gov.br/home/)

${ }^{39}$ BOSI, Ecléa. O TEMPO VIVO DA MEMÓRIA: ENSAIOS DE PSICOLOGIA SOCIAL. São Paulo: Atelier Editorial, 2003, 1994.

${ }^{40}$ PESAVENTO, Sandra Jatahy. O IMAGINÁRIO DA CIDADE: VISÕES LITERÁRIAS DO URBANO. Porto Alegre: Ed. UFRGS, 2002.
} 
moradia que participam ou tem membros participando da ocupação João Cândido (SP) e da ocupação Chico Mendes (RO), com a perspectiva e metodologia aqui apresentadas.

O registro das experiências de vida dessas pessoas e a compreensão de suas atividades cotidianas, de suas formas de organização, lutas, percepções da cidade são elementos importantes para uma história contemporânea, crítica do social e preocupada com as "massas anônimas”. Uma história com estruturas em movimento, enfatizadora das condições de vida material, embora sem colocar o fator econômico como condicionante absoluto da totalidade social; uma história que se preocupa com a sociedade global e a reconstrução dos fatos em séries passíveis de compreensão e explicação ${ }^{41}$ ". Orientada com esse compromisso com a história - que é acima de tudo um compromisso com a sociedade - essa pesquisa foi feita, e é por ele que as entrevistas foram construídas e serão apresentadas de modo integral. A nosso ver, essa é marca mais significativa de nosso trabalho, pois permitirá aos leitores a reconstrução de importantes aspectos das trajetórias dessas famílias, de suas concepções e ideais de cidade, que poderão ser constatadas diretamente nesta fonte, sem outros intermediários.

\section{CONSIDERAÇÕES SOBRE O CORPUS DOCUMENTAL}

O núcleo documental desta pesquisa é constituído pelas narrativas resultantes das entrevistas de história oral, que foram agrupadas em dois blocos: o dos colaboradores de São Paulo/Itapecerica da Serra e o dos colaboradores de Porto Velho, a fim de melhor compreendêlos em suas especificidades, bem como aos seus significados sociais e organização interna.

A opção pela história oral como conjunto de procedimentos para configurar as narrativas das famílias colaboradoras desta pesquisa se deu por entendê-la capaz de “captar” instâncias da experiência que normalmente os conhecimentos e abordagens historiográficas ou sociológicas tradicionais não alcançam, como os sonhos, os desejos, os segredos e projetos familiares ${ }^{42}$. A história oral de vida permite ao colaborador exercitar sua memória e narrar sua história, relacionando-a com a de sua família, de sua região, de seu país, bem como reavaliar as experiências vividas, recriar e colorir com novos matizes o que hoje é recordação.

As narrativas dessas famílias foram selecionadas por dizer muito sobre o nosso mundo, sobre o tempo e o espaço em que vivemos, e o fazerem de modo singular, repleto de subjetividade. Elas têm como substrato a própria experiência de vida: singular, coletiva e

\footnotetext{
41 VAINFAS, Ronaldo. OS PROTAGONISTAS ANÔNIMOS DA HISTÓRIA: MICRO-HISTÓRIA. Rio de Janeiro: Ed. Campus, 2002.

${ }^{42}$ Essa idéia foi apresentada pelo professor Alberto Lins Caldas, no Centro de Hermenêutica do Presente, na Universidade Federal de Rondônia.
} 
política. Falam sobre a complexidade da vida na cidade, sobre o trabalho, a alimentação, o passado, o futuro e sobre muitas outras coisas que o leitor terá a oportunidade de ler.

Trabalhamos com um universo de 16 narrativas $^{43}$. Desse total, dez são de integrantes da família da Laura, residentes em Itapecerica da Serra e São Paulo, e seis da família da Carol, residentes em Porto Velho. Foram construídas ao longo de 2007 e 2008, em múltiplas sessões de gravação, com exceção de duas: a do Cássio e a do Tonho, que foram feitas em uma única sessão, devido a incompatibilidade de nossos horários. Passamos a apresentá-las.

\footnotetext{
${ }^{43}$ Que passaram por um processo de transcriação, de “tradução do sentido”. Esse processo compreende um conjunto de procedimentos que se inicia com a escrita do projeto e vai até a construção das leituras, das interpretações dos textos resultantes das entrevistas.
} 
Namativas de uma família de São Paulo/Itapecenica da Sena. 


\section{Ana Terra \\ "Poderíamos dar um salto no processo de transformação do mundo se a Permacultura e a Esquerda se unissem”}

Estava pensando sobre as coisas relevantes que me tornaram militante. Estas coisas se deram ao longo de minha vida, em vários lugares: na casa onde cresci, na universidade, na ocupação Chico Mendes, nos congressos que participei, no meu trabalho. Acho que tem coisas relevantes inclusive na minha infância.

Quando minha mãe e eu saímos de Florianópolis, fomos morar em Vinhedo, no Marambaia, hoje um condomínio de gente muita rica. Quando chegamos, a transição de loteamento de algumas chácaras para condomínio de luxo estava acontecendo, mas ainda tinha muitos caseiros, sitiantes, chacareiros, e a minha mãe trabalhava como caseira. Depois esses sítios e chácaras foram gradualmente vendidos e casas grandes, luxuosas, foram se instalando.

A gente continuou por lá e depois de mais de dez ganhamos o pedacinho de terreno em que a gente morava. Ganhamos mesmo, com doação no papel e tudo, documento oficial; mas nossa situação lá era muito peculiar porque éramos pessoas pobres, duras... É difícil dizer pobre, né? Porque hoje em dia, quando penso nos recursos que tive acesso: pavimentação, luz elétrica, água, telefone... Lá havia recursos que geralmente na favela e em lugar muito ermo você não vê. Clube, escola não tinham, porque era um lugar muito despovoado antigamente e ficava mais perto da Anhangüera do que do centro de Vinhedo, e também porque já se partia do pressuposto de que as pessoas de Marambaia não estudavam lá, estudavam no Porto Seguro, um colégio de super-elit de Valinhos-barra-Campinas. O Marambaia era um condomínio onde as pessoas iam passar o fim de semana. Claro que quando se fala "pessoas do Marambaia”, nunca se pensa nos caseiros, nos seus filhos. Não tinha escola lá perto. Sempre tive que estudar longe.

Estudei em Valinhos uma época, numa escola meio cooperativa, estudei em Jundiaí, que é uma cidade vizinha, e em Vinhedo também, numa escola pública que era bem barra pesada. Se chamava Patriarca, estudei a primeira e a segunda série lá...

Eu tinha menos de três anos quando chegamos ao Marambaia e a nossa vida era mais ou menos assim: até os meus quatro anos e pouco, quando meu irmão Igor nasceu, eu era muito sozinha, muito solitária. Tinha poucas crianças relativamente próximas da minha casa, não tinha vizinho pertinho assim... Em geral eram filhas de gente que vinha passar o final de semana. Depois, quando o Igor já tinha quatro, cinco anos é que se formou uma turminha de pessoas que moravam lá. Nessa época eu tinha sei lá, nove, dez anos, o Igor tinha cinco, seis e as crianças da nossa turminha tinham idades intermediárias entre a minha e a dele. Nossa turminha era uma 
delícia. Gostava muito deles, não me importava que eles fossem mais novos. Na escola tinha amigos da minha idade e no Marambaia brincava com crianças menores do que eu.

Uma coisa interessante que para mim ficou muito clara e muito concreta, desde pequenininha, foi o chavão: “dinheiro não trás felicidade” Para mim isso era muito concreto porque as crianças do Marambaia com as quais me relacionava - e que todas tinham grana - iam brincar na minha casa, que era uma casa humilde, uma casa de caseiro reformada! Era de praxe, a gente chegava da escola, às vezes não dava nem tempo de tirar o uniforme já chegava o Bernardo, o Paulo, o Marco, o Caius, o Ico, já chegavam as crianças para brincar com o Igor. E era sempre na minha casa, que era uma casa que tinha um terreno com bem pouca estrutura. Não tinha churrasqueira, não tinha piscina, não tinha nada, mas era todo cheio de árvores e a gente pendurava cordas nas árvores para nos balançar.

Igor e eu inventávamos as nossas brincadeiras e os nossos brinquedos com os recursos que a gente tinha. Praticamente não comprávamos brinquedos, e construí-los também não era algo muito racional. Era da ordem de usar os recursos, mexer nas coisas e criar possibilidades de brincar. Tenho umas fotos da gente fazendo malabarismo, pulando muro, subindo em telhado, inventando gangorras com madeiras, inventando uns brinquedões com lona, com corda, com roldan... Várias brincadeiras com nossos amigos. Claro que com a convivência, as crianças acabam pegando as características umas das outras, então nos tornamos uma turma criativa e em qualquer lugar rolavam essas brincadeiras criativas, mas a minha casa continuava sendo o lugar onde as crianças sempre iam para brincar. Era o QG da gente. Ela sempre teve um clima muito interessante, muito gostoso.

Acho que minha mãe é meio bruxa, é engraçado! Sempre brinco com ela, digo que é uma anarquista, mas não sabe disso. Ela tem umas idéias interessantes... Minha mãe era muito parecida com aquele cara do filme "A vida é bela", que tinha aquelas sacadas para conseguir enriquecer a vida do menininho. Sempre quietinha, na dela, tímida, serena, tranqüila, muito diferente de mim. Ela é uma pessoa muito ligada à natureza, é bióloga, lê muito, muito, muito. Está sempre no jardim com um livrinho na mão, no solzinho... Uma pessoa simples que precisa de pouco para ficar bem. Os programas da minha mãe são coisas muito serenas e internas, ela é uma pessoa de um mundo interno extremamente rico e era “culpa” dela o clima que havia lá em casa, muito gostoso! Era um monte de criança que tinha recursos, sabe? Algumas não eram ricas, mas algumas eram! Tinham bug, tinham jipe, tinham tudo, mas iam dormir na minha casa, fazer guerra de almofada.

Em geral, nas casas, o lugar/ momento de congregação das pessoas é a mesa, na hora de comer. Lá em casa nunca foi assim, primeiro porque a gente nunca jantou, nunca teve o hábito de jantar. A gente almoçava, eu e o Igor ficávamos soltos pelo condomínio, brincando, e tardezinha 
comíamos um sanduíche. Comíamos bastante no café e na hora do almoço: cada um chegava, fazia seu prato e saia andando, não tinha essa união tradicional na hora do almoço. Nossa união era na hora em que seria o jantar porque a minha mãe, apesar de sempre ter morado sozinha com a gente, tinha uma cama de casal. Na época que meu pai veio morar com a gente e tal, ficou a cama. Então, sempre de tardezinha, depois de comer alguma coisa, íamos para a cama da minha mãe.

Ela ficava quietinha trabalhando, lendo, corrigindo provas, - ela foi professora dessa escola meio cooperativa em que eu estudei uma época, inclusive ela deu aula para mim uma época - fazendo essas coisas de professora de ciências, sentadinha na cama. Eu ficava fazendo lição de casa, o Igor brincando e sempre que tinha gato ou cachorro eles ficavam na cama também, todo mundo em cima da cama.. Os cachorros que tivemos sempre foram pequenos. A cama de minha mãe era o lugar onde a família se juntava., e os bichos da gente sempre foram muito queridos e a gente convivia com eles com muito carinho. Tenho lembranças muito aconchegantes dessas tardes e tardes e tardes que a gente passava ali, juntos, daquele jeito. Era lá que conversávamos sobre o dia. Nossa! Minha mãe educou a gente de um jeito muito gostoso, e isso me remete mesmo àquele filme do "A vida é bela", sabe? As criatividades que ela tinha, de como fazer da nossa vida, com aqueles recursos ali e aquelas coisas todas acontecendo, uma coisa aconchegante e bonita.

Acho que é legal contar um pouco sobre a Nova Escola também. Quando estava na primeira e segunda série estudei em uma escola pública em Vinhedo, chamada Patriarca, uma escola estadual com alto índice de violência, mesmo estando em uma cidade pequena. Vinhedo tinha uns 20 mil habitantes, eu acho. Apesar disso, adorava aquela escola, talvez porque ela tivesse pessoas mais próximas de mim, da minha classe social. Era uma escola pública que tinha desde gente muito pobre, filho de pedreiro, de doméstica, gente que morava na Capela, que era o "bairro pobre” de Vinhedo, até gente da classe média de Vinhedo, principalmente da classe média com tendências de Esquerda. Lembro muito bem de duas meninas que estudavam na minha classe na primeira série, que as mães eram do PT. Naquela época o PT era uma coisa considerada, "Nossa, o PT!!" Eu lembro muito vagamente que falavam de um cara chamado Lula, que tinha perdido a eleição para o Collor, e os pais delas dizendo que era pra ele ter ganhado.

Gostava muito dos meus colegas de classe, sabe? Achava eles legais, e hoje em dia penso que era por isso: porque eles eram menos ricos mesmo, pode parecer estranho, mas tem algumas coisas que a riqueza tira da gente, ou pelo menos, da maior parte das pessoas que vivem nela. 
Minha professora da primeira série, a pessoa que me alfabetizou, se chama Teí, e era de Esquerda. Tinha sido exilada na Ditadura e sofria de um problema sério na coluna por causa dos maus-tratos que recebera naquela época. Ela não ficava contando isso abertamente, mas hoje em dia lembro de várias coisas que “denunciavam” sua postura de Esquerda. Ensinou-nos a ler com jornal! Depois que nos ensinou as primeiras letras, passou a levar jornal com as manchetes, mostrava a manchete ou escrevia na lousa e a gente lia: "Po-lí-cia a-pre-en-de a-ni-ma-is do tráfi-co de a-ni-ma-is”. A gente lia tudo e ela falava: “O que significa isso? O que vocês entendem com isso aqui?” Leitura era sinônimo de interpretação, não era só decodificar! Tive a sorte de ser alfabetizada por essa pessoa!

Depois, quando estava na segunda série minha mãe conheceu a Vera, uma moça também de Esquerda que estava montando uma escola bem alternativa, lá em Valinhos. Uma escola comunitária. Não era nem pública nem privada nesse sentido. E era uma escola legal, com algumas coisas quase socialistas: a hora-aula e a hora-trabalho de todo mundo era igual: a do conselho de coordenadores (porque não tinha diretores), dos professores, das faxineiras, tudo. Uma escola pequena, de métodos que a gente poderia dizer que eram mais ou menos construtivistas.

Fui estudar nessa escola e minha mãe foi ser coordenadora de Ciências. Como a hora-trabalho das duas faxineiras era igual à de todo mundo, sobrava menos dinheiro, então, toda sexta-feira à tarde, na última hora de aula, ou na última meia hora, não sei, as crianças faziam faxina na sala. Era parte da rotina semanal limpar a sala de aula no fim de cada semana. E sabe que aquilo era muito legal? Acho que um pouco é aí que se lastreia o meu apreço pela auto-gestão até hoje. Naquela escola os recursos não eram muitos, não dava para pagar o número de faxineiras necessárias para manter tudo limpo, não havia dinheiro suficiente para isso, então a gente ajudava na conservação daquele espaço. Geralmente as pessoas são privadas da oportunidade de serem sujeitas de algumas características do espaço em que vivem, uma delas é a limpeza. A gente está muito separado desse mundo e lá na escola a gente não estava. Fiquei na Nova Escola até a sétima série, quando fui para o Universitário de Jundiaí.

Quando saí do Patriarca e fui para a Nova Escola me lembrava muito da primeira série, ficava retomando essas lembranças, talvez por isso, tenho tantas recordações da Teí, que por sinal, reencontrei há algum tempo. Fui até Águas de Santa Bárbara visitá-la quando descobri que ela estava no Brasil. Passei quatro dias lá, com ela e com o marido dela. Ela já está bem velhinha, mas é uma pessoa que não pára quieta e não vai parar nunca.

Engraçado como as coisas às vezes ficam latentes em nossa cabeça. Nunca tinha percebido, quando era pequena, que a Teí era uma pessoa de Esquerda, que queria transformar o mundo, mas me lembro que ela tinha muitas conversas comigo, minha mãe me conta que a Teí 
se identificava muito comigo e me levava para ter “conversas de mulher para mulher”. Lembro dela falando: "Você não precisa se conformar com como as cosias são. Não deixe fazerem injustiças com você” Hoje em dia isso é um substrato psíquico muito rico, muito, sei lá, oxigenante! Retomo essas coisas para me dar combustível, para solidificar quem sou e o que faço. Ao ter essa pretensão grande de mudar o mundo você precisa de muito fôlego!

Tenho medo de pensar que sou o que sou apenas porque tive a oportunidade de viver essas experiências, ou melhor, tenho medo que as pessoas que não viveram coisas semelhantes não possam desejar mudar o mundo. Quero muito que todo mundo possa se transformar como me senti transformar, mas tenho receio que as experiências que vivi sejam determinantes do que sou e que, portanto, pessoas que não viveram essas coisas não se tornem assim.

Quero acreditar que todo mundo é capaz de cada vez mais querer ardentemente mudar o mundo, e que todo mundo é capaz cada vez mais de construir a própria vida neste sentido, e construir a si mesmo nesse sentido. Não é abrir mão da vida ou de certo tipo de vida, é querer ter um outro. Não é abrir mão de ter dinheiro ou fazer uma carreira “bem sucedida”, é querer ter outras coisas que não dinheiro e que o dinheiro impede a gente de ter. E ter outras coisas que não uma “carreira bem sucedida”, porque esse “bem sucedida” é um falseamento, uma interpretação. Tenho medo de só ter tido a possibilidade de fazer essas escolhas porque tive um passado que me ajudou para isso. Nesse sentido acho que sou um pouco sartreana, apesar de não ter lido muito Sartre. Quero acreditar, e em certo sentido já acredito, que a vida é uma questão de escolhas. Então que tudo bem, tive essas coisas no passado que me ajudaram a ser o que sou, mas se não tivesse nenhuma delas, poderia ser capaz de tudo isso do mesmo jeito.

Há diversas formas de conseguir perceber o mundo, inclusive acho que a literatura é uma das que são bastante efetivas dentro deste universo em que a gente vive. a mais prática dentro deste universo em que a gente vive. Muita coisa você percebe lendo.

Gosto de me dedicar a pensar como cada pessoa, com suas vivências diferentes, consegue, a partir delas, chegar numa idéia e num jeito de viver que seja transformador.

Uma coisa que ia dizer do Marambaia, que acho interessante dizer, é sobre o início do seu enriquecimento. Quando eu tinha uns quinze anos havia um fenômeno muito interessante: “turmas” de adolescentes. Naquela época o Marambai já era bem povoado, tinha bastante gente porque as estradas estavam cada vez melhores, e porque Vinhedo não é longe de São Paulo: setenta e cinco quilômetros apenas- e as pessoas estavam se mudando para lá, muitas vezes dizendo que queriam sair da violência de São Paulo, mas o que aconteceu foi que levaram a violência para lá.

De um condomínio que durante a semana tinha um caráter praticamente rural, durante o fim de semana vivia cheio de barulhos de super motos e logo começou a ter barulhos de super 
motos a semana inteira. A gente brincava que lá a riqueza se media em decibéis. Quem tinha a moto mais barulhenta era o mais “tchananám”. Mas enfim, o fenômeno, que aconteceu nessa época era o seguinte: tinha essas turmas de adolescentes que agora moravam lá e muitos deles estavam envolvidos com Jiu-jitsu, estava na moda ser agressivo.

Os moradores do Marambaia não percebiam, mas a violência estava neles também, e não só na cidade, então, naquela época aquele condomínio já tinha muros em toda a sua volta, câmeras, câmeras ainda não, hoje em dia tem. Não foi nem uma nem duas vezes que os guardinhas que faziam a segurança daquele local foram espancados pelos filhos dos condôminos, pelos filhos de quinze, dezesseis, dezoito anos, que faziam academia, que eram bombados. Aquelas pessoas eram destruídas, cara! Os adolescentes de Marambaia... Teve vários casos de morte por causa de overdose, vários casos de morte por acidentes de trânsito, gente de quatorze, quinze anos dirigindo e morrendo em acidente. Era patológica a situação! E engraçado, a gente não fica sabendo dessas coisas, mas aquele condomínio era um lugar em que se você andasse às duas da manhã pela rua, a possibilidade de você ser abordado por um ladrão ou por um estuprador era mínima, aliás, acho que era nula, mas a possibilidade de você apanhar de uma "turma” de filhos de condôminos era muito alta.

O fenômeno antropológico que acontecia na nossa turminha era que as meninas acompanhavam os meninos para casa. Sempre que a gente ia embora, ia uma menina junto e voltava sozinha depois, porque era mais seguro você, sendo menina, andar pelo condomínio sozinha, do que sendo menino. Olha que coisa louca, olha a inversão! Acho que isso é muito significativo. Sou das Biológicas, mas tenho a impressão, brincando de me aventurar pelas Humanas, que isso é antropologicamente interessante de se estudar!

Com o tempo as pessoas da minha turma foram ficando cada vez com mais dinheiro, conhecendo pessoas com mais dinheiro e nossa relação se modificou muito. Hoje está dispersa, todo mundo entrando para a faculdade. Mesmo há dois, três anos atrás as pessoas da minha turma já faziam programas que o Igor não podia mais acompanhar. Hoje em dia o Igor se relaciona muito com os amigos dele de Jundiaí, tem uma bolsa de estudo numa escola de Jundiaí, tem uma banda lá, sai pela cidade. O pessoal lá não é rico, é classe média ou classe média alta. No Marambaia já é difícil ele conseguir acompanhar os programas dos meninos porque eles vão a lugares muito caros, fazem coisas muito caras. Às vezes, quando eles vão fazer churrasco em casa, o Ígor vai, mas já existe incompatibilidade em algumas coisas. Felizmente logo ele vai entrar na faculdade, e vai descobrir outros mundos que nem eu descobri.

Com relação à cidade, há que se dizer que Vinhedo mudou muito e acho que logo vai deixar de ser como é, porque as indústrias estão chegando e ela está se descaracterizando. Hoje é uma cidade meio turística, mas já está mudando. Tem muita gente começando a vender suas 
casas. Os ricos vão vendê-las para comprar em outros lugares, porque pelo que estou vendo, Vinhedo vai ficar um lugar degradado, sua qualidade ambiental já está caindo, aliás, tenho uma coisa interessante pra contar sobre isso: o último trabalho da minha mãe em Vinhedo. Ela se envolveu com uma ONG chamada "Elo Ambiental” e construiu dentro dessa Ong um projeto muito legal de educação ambiental, que envolveu todas as terceiras séries do ensino público da cidade.

Não sei precisar quantas crianças são, mas, devem ser umas 500 talvez até um pouco mais. Minha mãe e esse pessoal da Ong produziram um livrinho infantil, que conta a historinha de quatro crianças que moram em Vinhedo, descobrem um mapa, umas pistas e vão andando a procura de um tesouro perdido. No caminho vão conversando com as pessoas idosas da cidade, construindo a história da cidade. Eles encontram o tesouro, mas se deparam com um mistério: a água de Vinhedo está acabando. O livro termina com esse novo mistério, esse novo desafio. Daí começa o trabalho com as crianças da terceira série.

O livrinho é um livrinho infantil mesmo, foi editado, ficou bonitinho, todo colorido, com mapa, linha do tempo, bem legal. E aí as crianças da terceira série o lêem, os professores recebem uma apostila para trabalhar os conteúdos “água”, “meio-ambiente”, “poluição” e saem a campo com os alunos. Esses estudantes passaram pelos lugares onde as crianças da história passaram e tudo foi montado de forma que conseguissem percorrer a cidade nesse dia. No final, todas as crianças das terceiras séries conseguiram por si próprias, chegar à conclusão de que a água de Vinhedo está acabando porque os lugares de mananciais estão sendo desmatados, não estão sendo respeitados.

Este projeto foi uma coisa que chacoalhou a cidade inteira, teve uma repercussão muito grande. Foi feito por essa ONG em parceria com a Prefeitura de Vinhedo e com outras entidades, e o pessoal conseguiu se articular de um jeito muito legal, misturando o Público com o Privado, com o Terceiro setor, com tudo. Só em cidade pequena ainda dá pra fazer isso. Acho que foi a experiência de educação ambiental mais bem sucedida que já ouvi falar. Fez uma super diferença, saiu até resoluções municipais depois disso. Esse trabalho educativo pôs em pauta, de fato, o problema da água, comprou uma briga grande, inclusive com os industriais, porque as indústrias estavam ocupando aquela Bacia perto do Anhangüera. Naquela época era uma gestão de um engenheiro do PT, depois mudou, entrou um industrial, um representante da Associação Comercial para ser prefeito e a primeira coisa que fez foi cortar o projeto!

Minha mãe ficou bem... Não digo decepcionada porque acho que ela já esperava que isso fosse acontecer, nunca acreditou muito em poder institucional, também, mas acho que ela pensa: “Putz! Que droga! Isso podia continuar!” porque uma coisa é quando você pega todas as terceiras séries num ano, outra coisa é quando você pega todas as terceiras séries durante cinco 
anos, assim: pensando numa formação continuada. Em cinco anos você pega praticamente todas as crianças em idade escolar, você muda a cidade, muda o comportamento da cidade. Genial isso! Claro que sou suspeita, ela é minha mãe, né? Chamo minha mãe de “Dona Ru”, um apelido carinhoso, porque o nome dela é Ruth. Como ela deu aula na escola em que estudei, na Nova Escola, ficava com vergonha de chamá-la de mãe no meio das outras crianças, mas chamar de Ruth também era algo muito impessoal, então retomei o apelido pelo qual meu pai a chamava.

Quando entrei na Biologia, trouxe comigo a experiência de ter convivido com a diversidade, de ter sido uma pessoa muito "desendinheirada" no meio de pessoas tão ricas, e por isso, consegui me dar muito bem com todos. As pessoas criavam "panelinhas”, eu transitava por todas porque me dava com todos os "estilos". Isso foi muito importante porque me possibilitou uma riqueza de convívio muito grande, que nunca teria tido se fosse de um só grupo.

No curso de Biologia havia uma menina chamada Mai, uma baianinha que adoro. Hoje estamos bem distantes, mas tenho um carinho muito grande por essa menina. Ela tinha acabado de chegar a São Paulo, era de Salvador, então estava sofrendo de "banzo", se sentia muito mal no meio dos paulistas frios e objetivos. Era toda fofa, calorosa, carinhosa, linda, aí um belo dia ela se aproximou de mim e falou: “Ana, vai ter uma coisa chamada ENEB em Salvador - Encontro Nacional de Estudantes de Biologia, e to mó feliz porque acho que vai ser uma coisa muito legal!”. Alguns dias depois ela falou que ia ter um encontro regional de estudantes de Biologia bem pertinho de São Paulo, em Santo André, o EREB e me convidou para ir com ela. Os caras da FSA, que estavam organizando o EREB, haviam estado na Biologia para colar uns cartazes e os ajudamos. Colamos cartazes e distribuímos panfletinhos de divulgação. A Mai estava animada para ir.

Fui ver a data do EREBI e ele aconteceria em um feriado, dentro de poucos dias, justamente em uma semana que eu ia ter quatro provas e dois trabalhos para entregar, uma coisa enlouquecedora, aliás, essa semana eu já tinha apelidado de “semana da morte”. Falei para ela: “Ai Mai, não vou, não vai dar, tenho coisas para fazer e é esse feriado que vou usar para adiantar as coisas”. Aí ela falou assim: “Poxa, mas vai ser uma coisa que é importante para a gente, um encontro de estudantes de Biologia, a gente vai conhecer um monte de gente legal”. Lembro que comentei: “Ah, acho que vai ser importante mesmo o pessoalzinho ir, os calouros, mas acho que eu não preciso ir não, que já aprendi bastante. Mas acho importante sim as pessoas irem”. Estava pensando analogamente a como foi o Fórum Social Mundial para mim. Cheguei ao Fórum Social Mundial sem saber nada e o mundo se abriu para mim. Pensei: “Ah, vai ser a mesma coisa. Para quem ainda está verde o mundo vai se abrir, mas não vou”. Essa menina insistiu tanto para eu ir com ela que acabei aceitando. Portanto, foi muito mérito da Mai eu ter trombado com essas coisas todas que vou contar agora. 
Nesse encontro regional de Biologia tudo era diferente do que já tinha visto nos meus parcos cinco meses de política, e que eu achava que era muita coisa. Para começar, naquele tempo estava apaixonada pela idéia de assembléia, voto, mecanismos democráticos, que para uma pessoa que até então não conhecia muito bem esses mecanismos, era um grande avanço, mas no EREBI não era assim que as coisas funcionavam, a atmosfera era de muito carinho, muita arte, muita beleza. Uma coisa linda, um universo muito autogestionado, em que predominava o pensamento: "vamos juntar as pessoas para que elas cresçam juntas, façam política juntas num sentido mais profundo que o dos mecanismos padrão da política convencional, partidária”.

Quando cheguei lá estranhei um pouco, mas achei muito gostoso. A Mai abriu as asas, nunca vi aquela menina tão feliz! Gostei das pessoas, conheci gente fofa, linda, impressionante, mas estranhei um pouquinho porque o EREBI tem, por exemplo, um tipo de organização em que são os estudantes que fazem as atividades que vão manter o encontro funcionando, ou seja, em vez de o encontro ser caríssimo, onde a logística, a estrutura é toda paga pelas inscrições, boa parte dessa logística é realizada pelos próprios participantes. A gente não paga caro, mas trabalha no evento. Trabalha em um sentindo muito diferente do que se costuma chamar de trabalho. A gente tem que dividir tarefas, fazer as coisas... As pessoas se organizam em mutirões e cada um deles tem uma tarefa a realizar. Lembro direitinho: eu era do mutirão laranja, nossa primeira atividade era o “Acorda Maria Bonita”, acordar as pessoas. Não, não era isso não, nossa primeira atividade foi a mística do almoço.

Mística é uma coisa importada do MST, mas que no movimento de biologia foi tomando características próprias. No ENEBI ela consiste em uma apresentação, uma enquête, uma música, ou um momento em que as pessoas saem fazendo massagem uma nas outras, enfim, tem uma série de coisas que podem ser considerada Mística. Em geral é alguma coisa que o mutirão faz para tornar aquele momento -que sempre são os momentos das refeições - mais encantado, e de preferência com algum conteúdo político a ser passado, mas por analogia, por metáforas, de uma forma mais artística que um discurso ou um texto. Em nossa mística do almoço eu estava com o meu violãozinho e a gente decidiu tocar umas músicas engajadas e fazer uma decoração com folhas de Palmeira e flores. Ficou muito bonito o lugar. A gente tocou "Tanto Mar", do Chico Buarque, que é relativamente engajada, sorrateiramente engajada, se não me engano fala da Revolução dos Cravos; também tocou "Cirandeiro" e "Admirável Gado Novo", e outras que não me lembro mais tão bem.

O almoço era arroz, feijão e “coisas”, comida comum, só que nesses encontros sempre tem uma boa quantidade de comida vegetariana, porque na ficha de inscrição se pergunta: “é vegetariano (a)?”. Sempre tem algumas misturas vegetarianas com alguma "sustância”. Quem 
anima o encontro são os próprios participantes, são os mutirões, quem faz a comunicação também são eles, essa atividade é chamada Sinapse, e é bem legal, é uma das minhas preferidas. Quem acorda os outros, quem separa o lixo é tudo estudante. Geralmente tem uma coleta para lixo orgânico e uma para lixo reciclável e o mutirão que estiver responsável pelo lixo naquele dia vai recolhê-lo e administrar essa parte. Acho esse tipo de organização muito legal, desalienante. Quando você chega a um encontro, não está esperando “trabalhar”. Você “comprou” uma coisa, pagou a inscrição, tem uma relação de “cliente” com a comissão organizadora, e não é assim que as coisas funcionam nos Encontros de Biologia. A comissão organizadora muitas vezes se dilui no meio da galera. Nos melhores encontros essa comissão é ultra expandida: tem o pessoal do lugar que é sede do encontro, e tem também muita gente de fora que atua como comissão organizadora e faz muita coisa acontecer.

Foi muito lindo esse EREBI, muito importante para mim, especialmente a partir do segundo dia, porque teve uma discussão sobre Movimento de Biologia e comecei a entendê-lo. Lembro nitidamente do momento em que o Lívio - hoje em dia um grande amigo meu, do Rio de Janeiro - e que já tinha ido a muitos ENEBIs e EREBIs - começou a falar sobre o Consenso. Foi incrível porque eu estava acostumada que o jeito legal de resolver as coisas era por votação. Ele começou falando: “A, como a gente sabe, o Consenso é melhor do que o voto”, aí arregalei os olhões e pensei: “Como assim?” “Existe outro mecanismo de tomar decisões!”.

O encontro seguiu, tive várias conversas incríveis, tão incríveis como as que tinha com as pessoas que faziam política na USP, só que um pouco diferente, porque geralmente, na USP, minhas conversas eram com pessoas do DCE, que acreditavam em paradigmas um pouco diferentes: institucionais, da entidade e muitas vezes mais partidário. A partir de então nunca mais parei de ir aos ENEBIs e EREBIs, e sempre voltava renovada, tendo aprendido trinta milhões de coisas.

Tem vários elementos no Movimento de Biologia que são profundamente engajantes, a Vivência é um deles. Vivência consiste em dividir aqueles estudantes que estão no encontro em grupos um pouco menores, para conhecerem uma experiência que a Universidade nunca mostraria, ou raramente mostraria, como por exemplo, um grupo que trabalha com as pessoas do lixão, um parque ecológico que trabalha com uma metodologia diferente, um assentamento de um Movimento Social, ou um acampamento, um orfanato. Tem uma série de lugares em que as Vivências podem ser feitas. Então você pega aquele bando de estudantes, coloca em um ônibus e manda para um lugar onde eles vão aprender muita coisa, que eles estudariam apenas teoricamente ou ouviriam falar a respeito, mas a teoria é muito diferente do "estar lá”, do vivenciar. 
Quando as pessoas retornam da Vivência estão absolutamente turbinadas para mudar o mundo! É muito louco o efeito que isso tem nas pessoas, inclusive naquelas que chegaram ao encontro com uma postura totalmente “vim me divertir”. É muito raro alguém sair de uma Vivência sem estar profundamente tocado, incomodado com alguma coisa e deslumbrado com algumas possibilidades. O Lívio chamava essa metodologia de "metodologia do soco no estômago e depois abraço”, porque você vai, toma contato com alguma coisa que não é legal, fica conhecendo um problema sério, e ao mesmo tempo toma contato com alguém que está fazendo alguma coisa legal e quando volta, é acolhido por aquele ambiente erebiano ou enebiano onde se faz a socialização dessas vivências. Nessa socialização as pessoas contam o que fizeram, fazem apresentações sobre as coisas que conheceram, às vezes apresentações artísticas, e se sentam para conversar sobre o que podem fazer a respeito, como podem ajudar, se inserir nos trabalhos observados e daí surgem alguns projetos, alguns documentos. Muitas vezes surgem iniciativas, mas a meu ver, o mais importante, ou tão importante quanto, é que daí surgem vontades. É muito importante querer mudar as coisas e o ENEBI e o EREBI são universos que fazem as pessoas desejarem isso. Por este motivo eles são tão importantes para mim.

Estou trabalhando com coisas que são profundamente conectadas a esse mundo “enebiano”. Minha participação nesses encontros fez mudar minha concepção de trabalho, mas eu não percebia isso de forma muito clara, não via que estava mudando. Quando li o primeiro capítulo do Capital, com o Ricardo e um grupo de amigos, foi muito legal porque eu já estava indo a esses encontros fazia tempo e o Ricardo soube “explorar” muito bem essas experiências em nossos estudos sobre Valor de Uso, Valor de Troca, Trabalho Concreto e Trabalho Abstrato. Essas coisas se relacionam muito com a autogestão e o "fazer acontecer”, em vez de "pagar para que alguém faça”. Então eu tinha experiências concretas para entender o que eles, o Marx e o Ricardo estavam fazendo.

No finalzinho de 2003 escrevi um e-mail para o Márcio, meu melhor amigo, falando: “nossa, hoje em dia a palavra trabalho tomou um significado diferente para mim”, depois continuou tomando outros, continuei desenvolvendo conceitos para mim mesma, mas essa foi a primeira vez que contei isso a alguém. Eu sabia que a minha concepção de trabalho estava mudando. Nesse e-mail escrevi três coisas: que trabalho era os trampos de militância, no sentido de panfletar, ir fazer reunião e tal, mas as outras duas coisas não estou lembrando no momento, porque foram mudando com o tempo, foram se desenvolvendo. Não uso mais a categorização que usava, mas para mim era deslumbrante o fato de que minha idéia de trabalho estava mudando.

Hoje em dia, trabalho com Permacultura, além de várias outras coisas. Permacultura é difícil de explicar, mas tem a ver com construir e manter sistemas produtivos humanos. Sistemas 
agrícolas, de abrigo/moradia, de produção de energia - construir e manter esses sistemas de forma $100 \%$ sustentável ou rumando para esse horizonte. A idéia é conseguir sustentabilidade máxima. Claro que não é só isso, mas esse é um dos eixos que perpassa a Permacultura. Um de seus princípios é: "Produzir abundância para distribuir abundância”. Algo que opera em outra chave em relação ao capitalismo. Você não precisa juntar coisas para si, pois vai ter em abundância porque está todo mundo produzindo, e produzindo de um jeito o mais inteligente possível, o mais “professor pardal possível”. Permacultores são pardais, nesse sentido bonitinho do gibi... Eles criam, disseminam, distribuem meios de produção, a fim de que todos tenham as coisas que precisam.

Para desenvolver trabalho nessa área não é preciso um lugar fixo. Estou trabalhando com o Luís, um cara que as pessoas contratam para construir coisas sustentáveis, estruturas como forno a lenha, parede de bambu, construções feitas de coisas trazidas das caçambas... O Luís é genial, constrói qualquer coisa com qualquer coisa, e eu o ajudo, esse é um dos meus trabalhos.

Foi muito incrível o jeito que conheci o Luís, na verdade foi mais ou menos do jeito que conheci muita gente na minha vida: via grandes coincidências. No começo de 2006 eu ainda estava morando na ocupação Chico Mendes do MTST e trabalhando na Incubadora. Conheci um rapaz chamado Felipe Bannits, um rapaz também genial que tinha sido um dos fundadores da Incubadora e tem muito conhecimento sobre economia solidária. Gosto do jeito como ele lida com as informações e da relação que tem com a economia solidária, porque ela permeia muito a idéia de sustentabilidade ecológica e Permacultura, mas naquela época ainda não sabia o que era isso. Lembro que o Bannits estava dando um curso - ele é moleque assim, da nossa idade, mas estava dando um curso lá na FEA, sobre economia solidária e eu não podia ir porque era no mesmo horário que tinha reunião da Incubadora, só que a FEA e Incubadora ficam uma ao lado da outra, e por muita coincidência, no dia desse curso todas as pessoas que teriam reunião comigo faltaram, cada uma por um motivo. Fiquei sozinha e pensei: “Bom, reunião de um não existe então vou ver o curso" e foi a sorte porque o Bannits, assim como muitas outras pessoas que conheço, é um cara que atrai gente boa. No curso dele tinha muita gente legal, inclusive uma mulher que nunca tinha visto na vida, chamada Lolita. A Lolita é outra grande figura, foi a pessoa que fundou o ALFAUSP. Estapafurdiamente, não a conhecia!

O curso do Bannits foi delicioso porque tinha muita gente engajada, participativa, que já fazia coisas em economia solidária ou que já fazia coisas em outros universos que dialogam com o da economia solidária. Falei várias coisas, a Lolita falou várias coisas, foi aquele modelo de curso que não fica só o palestrante lá na frente falando, mas em que as pessoas se colocam e enriquecem o evento. Reparei na Lolita logo na primeira fala que ela fez, porque foi absolutamente marxista. Ela disse: "Não, porque a gente sabe, o dinheiro não é uma coisa em si, 
o dinheiro é um vale trabalho!” Nunca tinha visto ninguém usar esse termo, acredito que ela inventou esse jeito de caracterizar e eu fiquei fascinada porque é uma grande sacada, explicar isso de uma forma muito simples: “o dinheiro é um vale trabalho”. Depois ela fez outras comunicações: “Aqui na Economia...” - ela se formou em Economia, agora faz Pedagogia “Aqui na Economia a gente, na verdade, não estuda Economia porque Economia é uma coisa super grande, tem a ver com como as pessoas se organizam para suprir o que elas precisam. Nesse departamento a gente estuda Lucrologia, estuda um pedaço enviesado da Economia, com muito mais ênfase e as outras coisas a gente não estuda ou estuda de forma muito marginal, e na minha opinião as pessoas aqui sofrem de lucropatia”. Esse comentário dela foi muito engraçado, todo mundo riu. Achei aquilo demais e quando terminou o curso fui direto falar com ela, e foi engraçado, foi muito “amor à primeira vista”, porque ela veio na minha direção também. Falei: “Como é que eu não te conhecia?” E ela disse: “Como é que eu não te conhecia também?” A gente descobriu que tinha vários conhecidos em comum, amigos em comum, universos em comum e nunca tinha se cruzado. Interessante, né! Como pode? Ficamos amigas e ela me convidou para uma reunião sobre Permacultura.

O termo Permacultura me soava familiar, mas não sabia direito o que era. Infelizmente a reunião para a qual a Lolita me convidou seria em um dia que eu tinha trabalho de campo pela Incubadora, então não poderia ir, mas daí uma nova coincidência aconteceu e nesse dia meu trabalho de campo terminou mais cedo, então consegui chegar a tempo. Essa reunião foi um momento muito relevante na minha vida. Era pequena, tinha umas oito pessoas, e boa parte delas viria a ser muito importante na minha história de vida, cada uma por motivos diferentes. Nesta reunião estava o Bruno, da Geografia, um menino que é um gênio também e que acho que ainda vai ser muito famoso. Ele trabalha com Agricultura Biodinâmica, é um ativista dessa concepção de agricultura e dos princípios que o Steiner tinha quando fundou a Antroposofia. Fazia vários anos que não o via porque ele tinha ido para os Estados Unidos - Estados Unidos lado B obviamente, para a parte engajada dos Estados Unidos, mais preocupada com a vida do que com o lucro. Existe parte engajada nos Estados Unidos, existem várias pessoas muito legais nos Estados Unidos. De repente ele estava na reunião, totalmente diferente, com o cabelo crescido. A reunião já tinha começado quando percebi que era ele. Olhei para a roda de pessoas e lá estava ele, sorrindo. Quis conversar, mas como o permacultor já estava falando, peguei um papelzinho, escrevi SAUDADE e mostrei para ele, foi muito legal e isso já criou um ramo de coisas que aconteceram comigo, porque depois dessa reunião a gente sempre se vê, articula e realiza coisas juntos.

Havia outras três pessoas lá que viriam a ser também muito importantes para mim. Percebi que estavam juntas, porque faziam falas combinadas, que se pareciam muito e se 
completavam. Era uma trinca: duas meninas e um homem, e lembro que eles me chamaram a atenção, principalmente uma das meninas, a Cláudia. Ela citou a questão das corporações e por aquela fala percebi que ela tinha assistido ao filme The Corporation, que é uma obra que eu acho que todo militante deve ter e assistir. Nessa reunião também estava a Lolita e o Lucas do Eparreh que é um outro cara que também é importante na minha vida de militância.

Quando a reunião terminou cheguei para o cara da trinca, que é o Pablo, um argentino, e falei: “Conheço você de algum lugar!”, a gente tentou descobrir de onde era, mas não conseguiu. Percebi que ele tinha um sotaque "argentinado" e depois de muito tempo descobri que era o tiozinho que vendia lanche vegetariano no Fórum Social Mundial, era de lá que o conhecia. Fui conversar com esse cara, deu certo, bateu o santo e ele me fez um convite: "Olha, não sei o que você vai fazer agora, mas eu e minhas duas amigas fazemos parte de um movimento e gostaríamos de fazer uma breve apresentaçãozinha do que é esse movimento, você gostaria de ver?” Eu tinha reunião de noite, mas ainda faltavam umas duas horas e concordei. Isso é uma coisa interessante porque já fazia muito tempo que estava recusando esse tipo de convite. Estava muito atarefada, mas alguma coisa me dizia para ir. Acho que senti firmeza nele, e aí eles fizeram uma reunião do Movimento Humanista, ou pelo menos, uma amostra do que é uma reunião do Movimento Humanista, e fiquei absolutamente apaixonada por aquela trinca! Apaixonada no sentido de mentalmente seduzida. Eles eram demais, dava para ver que tinham consistência.

Era tudo gente bem mais velha do que eu: a Dani deveria ter uns 28 anos, a Cláudia uns 30 e o Pablo uns 40 e tantos. Foi muito louco, a reunião foi ótima, já peguei contato e falei de meu trabalho com uma rede de agricultores. Convidei-os para conhecer a Incubadora e meu projeto, eles foram, e isso me impressionou muito, porque é muito comum as pessoas dizerem: “Ah, quero conhecer sim”, mas aí acabam não indo. Ir é uma amostra de que são firmeza!

Apresentei a Incubadora para eles e em contrapartida fui convidada a conhecer o Movimento Humanista. Começamos a nos relacionar e desde então sou do Movimento Humanista também. Entrei mesmo, comecei a fazer atividades e lembro que a Cláudia falava para mim no começo: “Puxa, você já é tão cheia de ativismos!” e eu: “Ah, para coisas importantes a gente fabrica tempo”.

O Movimento Humanista foi criado na Argentina, na década de 1960 e tem uma estrutura muito anárquica, digamos assim, pois é constituído de conselhos independentes., ligados em rede. São centenas de conselhos pelo mundo todo, é um Movimento que está bem espalhado pelo mundo. Em termos de pessoas atingidas, de pessoas envolvidas no que a gente faz, deve ter... sei lá, uns dois milhões de pessoas, mas de militantes deve ter uns 200 mil. Os fundadores buscaram como fonte teórica e de princípios algumas filosofias ocidentais como Sartre e Reich, e outras 
não-ocidentais, como Tantra e Taoísmo. É um movimento muito rico justamente por causa disso. A meu ver - e eu não sou nenhuma grande entendida da influência teórica de seus fundadores uma das maiores influências é o Existencialismo - porque você lê os livros do Silo, por exemplo, que é um dos grandes militantes, e fala: “Nossa, isso aqui é Sartre de cabo a rabo”. Tem também um tempero de Steiner e um tanto de filosofias de Esquerda compostas, não sei o quanto de Marxismo, precisamente, mas combina com o Marxismo. Você vê que é uma salada, uma sopa e acho muito consistente sua filosofia, gosto muito, sigo bastante.

Esse Pablo, que me apresentou o Movimento Humanista, nasceu na Argentina. Quando ele tinha 13 anos estourou a ditadura e a família dele toda foi destruída, por ser opositora ao regime. O pai morreu na ditadura, a irmã mais velha, que tinha 18 anos, morreu na ditadura, foi da guerrilha armada. A irmã era casada com um estudante de Medicina que também morreu na ditadura, eles tinham uma filhinha bebê. O Pablo, com 13 anos tinha uma sobrinha que tinha acabado de nascer e ah! Ele estudava em uma escola marxista. Viu os professores sumirem e depois, “magicamente” surgirem professores plantados pelo governo ali, chacina! Muitos professores dele morreram e ele fugiu, foi embora viver nos Andes e conheceu um monte de gente alternativa. É um cara que tem uma história muito interessante, sabe? E é permacultor, fez o curso de PDC junto com a Lolita, por isso estava nessa reunião. Ele me contou muito sobre Permacultura e disse uma frase que para mim soou muito forte: “Acredito que a Permacultura vai ser tão importante para o século XXI como o Marxismo foi para o século XX”. Hoje em dia acho que isso faz sentido.

O Iluminismo foi muito importante para o século XVIII, XIX, XX e está sendo para o XXI, o Marxismo, que inclusive tem raiz em comum com o Iluminismo foi muito importante para o século XX e continua sendo para o XXI. Acho que a Permacultura vai somar. Tem potencial e se a gente fizer esse potencial acontecer, vai desempenhar um papel fundamental na mudança da humanidade. A gente vai produzir recurso para todo mundo e permitir que todos tenham uma vida rica, no sentido de ter o que precisa, mas não só coisas materiais, rica no sentido de ser o sujeito daquela produção e da concepção de como produzi-la.

Permacultura tem muito a ver com você pensar os meios de produção, criar formas, trocar idéia com o outro, criar tanto coisas de mínima escala, como um liquidificador a manivela, que você não precisa de energia elétrica para fazer funcionar, como coisas grandes: pequenas indústrias, mas num sentido muito diferente do que a gente tem de indústria hoje. Para começar, o alicerce dessa indústria não vai ser construído com cimento, que é um veneno horroroso, é uma das coisas que mais poluem o ambiente, tanto em sua produção, em sua mineração, como quando se faz as coisas com ele. Provavelmente essas novas indústrias concebidas por esse ideal serão movidas a várias fontes de energia que se complementam, em vez de uma única grande fonte, 
como uma hidrelétrica de Tijuco Alto, que querem construir. Nossa, a Votorantin é tudo o que a Permacultura não quer. É impressionante como ela faz celulose, cimento e como gera energia,com barragem que arregaça! É totalmente o oposto da Permacultura. Nesse sentido, a Permacultura é profundamente anticapitalista e profundamente humanizadora, porque em muitos aspectos da vida ela emancipa.

Já estava começando a ouvir bastante sobre Permacultura, quando em Maio de 2007 rolou aqui no Brasil - isso para mim foi uma coincidência maravilhosa - a Conferência Mundial de Permacultura, que é bienal e roda os continentes. Então a chance de ela cair no Brasil, justamente em São Paulo e no momento em que eu estava tomando contato com ela foi uma coisa linda! Fui à Conferência, consegui um esquema para ir de graça, porque custava R\$: 100,00 a entrada. Naquele tempo, menos de um ano atrás, eu já estava com muita coisa na cabeça que misturava Marxismo, Permacultura, Novo Humanismo, as coisas que o Bruno me contava sobre a Antroposofia e a Agricultura Biodinâmica, Existencialismo, que é a base de como o Ricardo pensa, e puxa, vários anos de Ricardo na veia... Então estava tudo misturado na minha cabeça e tinha a impressão de que uma das melhores coisas para se fazer no mundo, na Esquerda e no universo dos que querem mudar o mundo é miscigenar diferentes matrizes teóricas e diferentes recursos práticos.

Nesse encontro teve uma mesa em que estava uma cubana falando de agricultura urbana em Havana, uma canadense falando de um projeto que eles têm de boicotar as grandessíssimas empresas, tachá-las com impostos sobre a movimentação financeira e tudo mais, um cara da Finlândia falando sobre a Ecovilas, um permacultor norte-americano, e um sul-africano falando sobre algumas iniciativas lá da África do Sul. Era uma mesa super composta, linda! Achei o máximo e no final fui fazer uma fala e disse alguma coisa nesse sentido: de juntar várias matrizes teóricas, práticas e experiências para transformar nossa realidade. Contei muito brevemente sobre o Movimento Humanista, o MTST e sobre o Acampamento Chico Mendes e como poderíamos dar um salto no processo de transformação do mundo se a Permacultura e a Esquerda se unissem.

Minha fala fez um sucesso grandão, a galera aplaudiu, fiquei até meio sem jeito e depois as pessoas vieram falar comigo! A cubana me deu uma nota de três Pesos que tem a cara do Che e me convidou para ir para lá. Fiquei assim: meio perdida, foi muito bom. As pessoas gostaram da idéia, talvez todas elas já a tivessem, mas nunca tinham expressado daquele jeito. Um dos caras que também veio me procurar foi um armênio chamado Nicholas, que disse: "Eu to indo num outro evento de Permacultura que vai ter lá na Amazônia e quando voltar quero falar com você e conhecer o acampamento em que você está morando” E aí foi muito legal porque realmente quando ele voltou da Amazônia me mandou um e-mail, em inglês, evidentemente, 
porque não falo armênio e nem ele português, e a gente foi para a ocupação. Foi muito bonito, um momento especial - que eu espero que se repita muitas vezes...

Na verdade, já não estava mais morando na ocupação, não tinha mais muitos vínculos políticos com o MTST. Mantenho apenas vínculos emocionais com pessoas muito queridas que conheci na ocupação Chico Mendes e na João Cândido. Apesar de não fazer mais parte desse Movimento, quero dizer que o acampamento Chico Mendes me deu muitas coisas, lembranças, amigos, coisas que estão em mim, ferramentas de pensamento que adquiri lá. É uma coisa muito louca viver numa ocupação porque eu tinha lido um pouco de Marx e percebia claramente várias das coisas que ele escreveu Aquela vivência foi muito importante, por me mostrar no dia-a-dia algumas coisas que nunca imaginei que fosse ver fora dos exercícios mentais dos pensadores. É muito legal, então o que não me falta são recordações! Esse anel aqui, por exemplo, ganhei de um companheiro do MST quando eu e outras pessoas da Ciranda fomos fazer um curso sobre educação infantil no Pau d’alho, que é aquele sítio do MST em Ribeirão Preto, doado pela Igreja. Um companheiro chamado Paulinho, que conheci lá, me deu esse anel de coco, com essa pontinha. É um anel que representa a aliança com o povo pobre, tem essa simbologia, representa esse compromisso.

Lembro que outro dia estava mandando um e-mail para um amigo dizendo que continuo com o coração meio partido, meio preenchido de Chico Mendes. Taboão da Serra para mim sempre vai ser isso. Nunca mais vai deixar de ter o Chico Mendes lá dentro, para mim, sabe? É o lugar onde a Ocupação nasceu, e mesmo essa dor muito grande que sinto ao passar onde é o terreno e ver aquilo tudo destruído e queimado, é importante. Lembro que depois do despejo passei as semanas seguintes sem olhar para lá, não porque não quisesse, mas porque não estava indo lá, não tinha mais onde morar, precisava resolver algumas coisas. Certo dia a gente ia ter uma reunião do setor de educação na casa de uma ex-acampada que mora perto de onde ficava a ocupação, do lado do rio. Quando desci do ônibus, andei até perto daquela pontezinha e quando ia virar para ir para casa da Cleuza, olhei o terreno, de longe já se reconhece que está muito diferente, e falei: vou lá! Preciso passar por isso. Isso foi duas, três semanas depois do despejo.

Entrei naquele lugar e enquanto caminhava, me lembrava direitinho onde tinha sido o barraco de cada pessoa, onde tinha sido a Ciranda. Tudo destruído, algumas ruínas parcialmente reconhecíveis, lembro que me remeteu muito a Hiroshima. Em 2005, no aniversário de Hiroshima, decidi que ia estudar sobre ela, ia passar o dia estudando o que faz a bomba atômica. Passei o dia inteiro no computador do lugar onde trabalhava pegando fotos, relatos, desenhos, imagens - e chorando.

Aquele terreno onde tinha sido o nosso Acampamento me lembrou muito as ruínas de Hiroshima, pode até parecer uma comparação que não cabe, mas foi o que me veio na cabeça e 
lembro que, nossa, parece até coisa de filme... A gente tinha plantado uma árvore - uma árvore simbólica, com madeirinhas pregadas e papel crepom verde em volta, então parecia uma árvore de cenário e nela - isso foi uma mística que a gente fez - a gente pregou plaquinhas de madeira que tinham vários escritos: Igualdade, Educação, Amor, Utopia, várias coisas, e quando cheguei lá, algumas dessas plaquinhas estavam pelo chão, parcialmente preservadas. Aí não agüentei, desabei, chorei como uma criança. Retirei-as do chão e guardo-as comigo. Parece uma coisa meio maluca, mas acho que não é. Queria passar por aquilo, sabe? Sei lá, dizer tchau, me expor àquela dor muito ruim de ver o poder de destruição que quem tem poder possui. Aquilo era uma cidade que a gente construiu. Se tivessem nos deixado ficar naquele lugar, ele seria muito diferente do que é hoje. Hoje é um lugar de desova de cadáveres.

Acho que foi importante eu passar por essa coisa tão violenta de sentir que aquilo foi destruído. Se por um lado, para mim, o carinho que tenho pelas pessoas é combustível para querer mudar o mundo, preciso também aprender a transformar em combustível esses sofrimentos, esses grandes incômodos. Quero ter essas duas formas de combustível: o carinho e o incômodo e olha, a lembrança de passar pelo Chico Mendes e encontrar aquelas plaquinhas no chão me acompanha e é combustível. Uma coisa muito forte.

Quando o permacultor armênio, o Nicholas regressou da Amazônia, me procurou e o levei até a ocupação João Cândido, em Itapecerica da Serra. Foi incrível ver um permacultor dentro de um acampamento de sem-teto! Ver as coisas que fez ali com as pessoas, as idéias simples de como resolver os 30 milhões de problemas logísticos, estruturais, que aparecem quando você precisa construir sua casa de uma forma não-convencional. A Permacultura dá conta de muita coisa, dá conta de produzir de forma a sair do sistema mesmo, dá conta de organizar o espaço e os recursos disponíveis.

Lembro de um momento emblemático: estávamos eu, ele e o Rodrigo, no barraco do almoxarifado. Já estava de noite, tínhamos uma única vela e não tínhamos dinheiro para comprar mais. Estava tudo escuro no barraco e teve uma hora que o Rodrigo derrubou alguma coisa, que se espalhou pelo chão e o Nicholas falou: "Ele derrubou isso porque está escuro, ele não está enxergando, vamos pensar em como resolver isso, sendo que só temos uma vela”. Ele olhou em volta e falou: "Essa vela tem uma quantidade de luz que está se espalhando pelo barraco todo, não é uma quantidade muito grande, mas está iluminando o teto, aquela parede ali atrás e a porta. A gente só precisa de luz aqui, aqui e aqui”, ou seja: no armário e nas duas prateleiras. E continuou: “a gente não precisa enxergar a porta, só na hora que formos sair e também não precisamos enxergar o telhado nem aquela parede ali atrás, então se a gente conseguir arranjar alguma coisa que reflita a luz da vela vai ficar mais escuro a região da porta, do telhado e atrás, porque essa luz não vai para lá, mas a gente vai conseguir direcioná-la para onde é preciso” Aí 
ele achou uma panela toda torta, tipo frigideira de alumínio, sem ser de teflon, pegou-a pelo cabo e falou: "Isso daqui vai dar" e entregou-a a mim, junto com a vela. Peguei a frigideira e fiz conforme ele me indicou: pus o cabo para baixo, de modo a segurar, coloquei a vela na paredinha dela e ela virou um farolete. De repente fez-se a luz! A gente conseguiu enxergar muito bem as coisas!

Lembro que o Rodrigo ficou fascinado com aquilo, ele olhava e falava "Meu! Como assim? Que idéia simples e genial!” Aquele foi um momento muito bonito de miscigenação, do que pode ser a interação entre uma pessoa do universo da Permacultura e uma do universo dos Movimentos Sociais. Estava ali, na minha frente, acontecendo.

O Nicholas o tempo todo falava para mim: "Você tem que fazer o PDC, Ana! Você tem que fazer o PDC porque ele vai favorecer sua militância” O PDC isso, o PDC aquilo. PDC é um curso de Permacultura com duração de 72 horas, você vai para um lugar e aprende um monte de coisas. Eu falava: "Nicholas, não tenho como fazer o PDC, porque custa muito caro, não tenho nem chance!”, mas ele ficava insistindo o tempo todo. Alguns meses depois, estava conversando com ele pela internet, ele já estava na Armênia e falou: “E aí, Ana, já fez o PDC?” Falei: “Não, Nicholas, não tem como” e ele falou: “Não tem como por quê? Não vai ter PCD em São Paulo?”.

A possibilidade de ter PDC em São Paulo é muito pequena e esse curso é caro porque, o universo da Permacultura ainda não está bem integrado com o universo da Esquerda, como deveria, e além do mais, ela é feita de gente... De qualquer forma, não são pessoas que vieram do futuro e tem outra cabeça, são pessoas que estão aprendendo a ser revolucionárias em muitos aspectos, mas que nos outros são gente comum, cobram pelas coisas, às vezes vivem disso e não tem a idéia de: "nossa vou espalhar meus conhecimentos pelo mundo para que todo mundo seja permacultor e sejamos todos felizes”. Talvez quem tenha que dar esse passo seja alguém dos Movimentos Sociais. E aí ele me perguntou se eu já tinha feito o PDC, falei não e ele disse: “Ana, em algum momento é importante que você faça o PDC”. Ta bom, mais um tempinho depois, ele me escreveu de novo perguntando e eu disse: “Viche, Nicholas, ta osso!” "E quando é que vão ter PDC em São Paulo?” "Por coincidência vai ter semana que vem, vai ser ali na Casa da Floresta”. Ele perguntou: "Você tem dinheiro para fazer? Respondi: "Não” e ele: "Eu pago para você!” Eu disse: “Como assim você paga, Nicholas? São 600 contos!”. Aí ele falou: “Ah, eu ganho em Euro!” - e pagou o PDC para mim.

Fui fazer o PDC e lá encontrei o Luis Vieira, um dos maiores permacultores do Brasil, e que eu já tinha conhecido por intermédio do Pablo. Luis e eu já nos dávamos bem e quando a gente se encontrou lá no PDC aconteceu uma coisa muito louca: ele virou para mim e falou: “Ana, bora trabalhar comigo? Ta caindo um monte de trabalho aqui para mim. Depois que o filme Al Gore saiu todo mundo descobriu a idéia de sustentabilidade, as pessoas estão 
começando a fazer isso. Vamos lá?” Falei que já estava trabalhando e não sabia se ia dar. Ele insistiu e pedi aquela noite para pensar. Fiquei a noite toda rolando no saco de dormi, pensando e resolvi me jogar, no dia seguinte falei: "Luis, eu vou, mas dá um tempinho para eu ir entrando em transição na Incubadora e não fazer muita falta no projeto que estou participando. Vou diminuindo minha carga horária e começando a trabalhar com você”.

Fiz isso e hoje em dia é muito legal porque o trabalho que faço não é um trabalho de bater ponto. Sempre que ele tem alguma demanda ali, uma demolição ou construção de alguma coisa, me avisa e se eu puder ir, vou, se não puder não vou e tudo bem, então não tenho horários e posso fazer o que estou fazendo agora. Liguei para o Luís há umas quatro semanas e falei que ia desaparecer por umas semanas porque quero me dedicar exclusivamente à luta contra a barragem do Tijuco Alto, e ele não só me deu a maior força como de vez em quando manda uns e-mails perguntando como está a situação, então é o trampo perfeito para quem quer militar. Perfeito! E fora isso, estou aprendendo muitas coisas.

Minha relação com o Luís é muito amistosa! Lembra a relação de mestres e aprendizes medievais. Sabe aqueles artesãos que levavam os aprendizes junto? É bem assim, o Luís vai fazendo as coisas e vou junto, aprendendo. Ele é o mestre e tem a maior paciência do mundo para explicar. Esse é um dos meus trampos, às vezes remunerado, agora, como falei, meu conceito de trabalho foi mudando muito e especialmente depois que li o primeiro capítulo do capital, mudou bastante. A idéia de realizar trabalho abstrato para mim, hoje, é uma coisa asquerosa. Não consigo conceber. Sei que talvez algum dia eu precise fazer isso, mas trabalho concreto é uma coisa tão bonita! Você fazer aquilo que é importante que seja feito, que é bom, bonito, que é preciso... Fazer as coisas que precisam ser feitas e não alguma coisa qualquer que vai te dar dinheiro para comprar o que você precisa. A Permacultura tem muito a ver com isso, com realizar trabalho concreto. Tem gente que vai vender curso de Permacultura, vender o seu trabalho, como o próprio Luís está vendendo, mas é uma aproximação do que é trabalho concreto e conforme você vai ficando craque, tem várias coisas que não vai mais precisar comprar, porque você mesmo vai fazê-las. E quanto às coisas que você não sabe fazer, mas outro permacultor sabe, é só fazer uma troca. Isso é uma aproximação de trabalho concreto e acredito que seja a maior aproximação que existiu. Isso é revolucionário, ou pelo menos, potencialmente revolucionário. Acho que a Permacultura na mão de um marxista é uma bomba, uma coisa muito poderosa, por isso quero socializá-la, disseminá-la por aí.

Uma outra questão que a Permacultura envolve é a alimentação, a produção e a qualidade dos alimentos. Alimentação é um pedaço da vida da gente. Dentro do paradigma capitalista ela é muito separada das outras atividades, fragmentada, assim como tudo. O ser humano ocidental, capitalista, da atualidade é um bichinho muito fragmentado e não tem meios 
nem de perceber o quanto a alimentação é uma coisa integrada com a produção, com o meio de vida e com a saúde dele. A indústria alimentícia, assim como qualquer indústria capitalista tem como objetivo lucrar, não tem como objetivo a saúde das pessoas. No momento em que a saúde dos consumidores de seus produtos for um limitante jurídico para suas atividades ela vai se adequar até onde a lei manda, ou melhor: até onde ela consegue burlar a lei, porque sempre encontra subterfúgios. O que está escrito em um rótulo de um alimento nunca é bem aquilo. Deixe-me contar uma coisa sobre margarina. Sabe qual é a cor da margarina quando ela sai daqueles grandes tonéis preparadores? Antes de ela receber uma boa doze de agentes branqueadores, que pode ser soda cáustica, por exemplo, para depois receber o corante amarelo, sabe qual é a cor dela? Cinza! Uma coisa medonha. Isso quem me contou foi o Bruno. Quem mais me falou sobre alimentação até hoje foi ele, me contou muita coisa, tanto que as pessoas costumam chama-lo de "Bruno Orgânico”, ou "Bruno Biodinâmico”, porque ele trabalha com biodinâmica, que é uma coisa muito específica... Ele me contou que a molécula da substância base da margarina é praticamente a mesma molécula da tinta Suvinil! E mais um dado: barata não come margarina, rato não come margarina. Só isso já é um indicador tão significativo quanto “Coca-cola desentope pia”, essas coisas irrelevantes...

Alimentação é uma coisa muito séria. As pessoas muitas vezes não fazem idéia do que estão comendo e dos elementos que o constituem. Aquilo que estão comendo só é bonitinho porque tem corante para a parte visual, acidulantes e outros “antes” para a parte do gosto, aromatizante para parte do cheiro, e também outros “antes” para a parte da consistência e tudo o mais. É tudo artificial, feito com umas coisas bizarras e quanto mais barato for para a indústria, mais ela vai usar. Tem um monte de derivados de petróleo, tem um monte de transgênicos, um monte de porcarias. Penso que as pessoas que se alimentam de coisas industrializadas vão ter uma expectativa de vida menor que a dos avós delas. Hoje em dia nossos avós estão vivendo até os 80, à vezes até os 90 ou 100 anos e a tendência deveria ser cada vez mais a expectativa de vida subir, mas não acho que isso vá acontecer.

Para a minha geração, que está comendo margarina, salgadinho, chiclete, todo tipo de bolacha, doces industriais e até rango industrial, acho que a expectativa de vida não vai muito longe. Com sessenta, setenta anos quem se alimenta dessas coisas já vai estar completamente capenga. Talvez até consiga durar mais algum tanto de anos, com base em um monte de remédios. Só que remédio é outra coisa que meu deus do céu! Fujam dos remédios alopáticos! Tem tantas contra-indicações que não entram no rótulo que você fica com o fígado detonado se usar alopatia, e o fígado é da base de como o seu corpo se vira para se manter funcionando bem. A saúde das pessoas é muito maquilada hoje em dia. Já ouvi gente dizer que estamos no meio de 
uma “epidemia” de câncer, não sei se é isso mesmo, mas acho possível, porque a alimentação que a gente tem é uma coisa com a qual não co-evoluímos para ter.

Agrotóxico: as pessoas morrem de medo de comprar verdura que venha com bichinho, como se o bichinho fosse o problema. Você tem um aparato complexo chamado sistema imunológico no seu corpo, que evoluiu milhões de anos para ser capaz de combater bichinhos, bactérias, vírus, protozoários e várias outras coisas. Claro que tem alguns deles capazes de nos causar doenças, mas a gente já sabe muitas vezes como evitá-las, com procedimentos simples de higiene. Agrotóxico não serve para evitar problemas bacterianos ou qualquer coisa assim, serve apenas para deixar a planta visualmente mais bonita, e adubo químico serve para... Adubo químico é bomba! Sabe gente que toma esteróide e fica totalmente zoada? A planta com adubo químico também fica assim, adubo químico é injeção na veia! Essas coisas servem para vender melhor o produto, mas causam estragos terríveis à saúde, porque se o seu sistema imunológico evoluiu durante milhões de anos para combater bactérias, não evoluiu durante milhões de anos para combater venenos, e a gente está ingerindo venenos!

As pessoas têm essa paranóia, essa histeria em torno da higienização, que é uma coisa muito recente e um pouco patológica mesmo. Sabe aquelas pessoas que têm TOC e precisam lavar tudo o tempo todo? Parece que estamos todos assim. Todos os ocidentais têm TOC e não sabem. Ficamos evitando micro-organismos e consumindo veneno, consumindo veneno, consumindo veneno. É muito não-sábio! As pessoas não têm noção, e estou dizendo isso como representante dessas pessoas, porque também era assim, também me alimentava errado. Abacate, o que é abacate? Abacate é rango! Você vai comer pão no café da manhã? Pão branco? Coisa mais venenosa que tem: farinha branca, arroz banco, açúcar branco. É tudo branco, tudo refinado, tamanho desperdício de energia e de nutrição que dá aflição até de pensar! Nesse ponto a Permacultura também entra porque pensa muito na segurança alimentar, uma das coisas que o permacultor sempre procura fazer é conseguir o máximo de soberania alimentar.

O pessoal fala muito em segurança alimentar, mas tem uma coisa muito mais legal que é a soberania alimentar, um termo que a primeira vez que ouvi foi através de um senhor chamado Sebastião Pinheiro, um permacultor fenomenal. É o cara que fala sobre o deserto verde de eucalipto e sobre uma serie de questões agro-ecológicas muito pertinentes para nosso tempo. Ele disse: “Gente, segurança alimentar é ótimo, mas soberania alimentar é o que a gente precisa ter, porque a soberania alimentar garante a segurança. A gente tem que ser sujeitos da nossa alimentação, quanto mais a gente puder saber de onde vem, plantar, nos auto-abastecer, melhor!”.

Tenho aqui no fundo dessa quitinetezinha um vasinho com bertálias plantadas. A bertália é uma verdura trepadeira deliciosa, você planta, rega e não precisa ficar cuidando, aliás, 
depois que ela atinge certo tamanho você nem precisa mais regar, não é que nem horta de hortaliça, que demanda muito trabalho. Você vai lá pega umas folhinhas dela e come na salada, ou então refogado. É uma delícia! A forma dela lembra um espinafre, mas o gosto lembra mais uma alface, é uma delícia. Existe muita coisa nesse mundo que o capitalismo não deixa a gente saber, existem muitos recurso para a gente se alimentar, conseguir ter saúde. A quantidade de plantas medicinais, a quantidade de técnicas simples para as pessoas manterem a saúde é extensa. Tomar um copo de água antes de dormir e depois de acordar, por exemplo, evita muita doença, o cuidado com a alimentação, o cuidado com a hidratação, o extremo cuidado para não ficar consumindo veneno, uma vida que não seja sedentária, que tenha exercício - por exercício leia-se de Tai Shi e Yoga até correr - todas essas coisas garantem muito mais a nossa saúde do que qualquer remédio - e quando precisa de remédio, tem planta medicinal a rodo. Eu tenho dois livrinhos aqui com quinhentas plantas medicinais que você planta em um vasinho dentro de casa, então, se todas as pessoas, se muitas pessoas descobrem essas coisas a gente consegue esvaziar o Capitalismo.

Não acredito que seja possível matar o Capitalismo de porrada, não acredito mais. Acho que ele só tem duas formas de morrer: doença, porque já está doente, já tem claros sinais de que é uma sociedade doente e um sistema doente, mas essa possibilidade de ele morrer não me agrada nada, porque significa ele cair e as pessoas caírem junto. Significa grandes crises de recursos, grandes crises financeiras, da Bolsa de 1929 para cima. Coisas muito piores. E outro jeito de matá-lo é por inanição. É esvaziar, sair fora dele, construir uma outra cultura a partir dos interstícios dele próprio, e tem espaço para isso. Você pode montar pequenas cooperativas de produzir sabão, pode montar pequenos grupos produtivos, fazer um monte de coisas. E terra para fazer isso? Ocupa! Claro que vai ter problemas, Polícia em cima... Não significa que o Capitalismo vai ficar quietinho, deixando a gente fazer isso tudo em paz até de repente ele morrer de inanição, mas acho que só é possível derrubá-lo e salvar o ser humano no processo, salvar a vida do planeta no processo se for desse jeito, se for juntando diferentes universos de conhecimento, de práticas, de valores que são alternativos a ele, miscigenando-os de diferentes formas, em diferentes lugares, conforme as especificidades do contexto e das pessoas que o estão fazendo acontecer. É uma possibilidade que vejo e pratico junto com outras pessoas e a gente está cada vez fazendo mais. 


\section{Tonho}

\section{“Não basta o Leninismo, não basta o Marxismo, não basta Pragmatismo nem nenhum Letrismo, se não tiver Humanismo”}

Ingressei no Movimento dos Trabalhadores Sem-Teto em 2001. A primeira ocupação da qual participei foi a Anita Garibaldi.

Tenho mais ou menos seis anos de participação, mas não me acho melhor do que os outros por causa disso. Dispenso a hierarquia!

Até eu chegar ao MTST foi um processo muito longo, que começou antes mesmo de eu nascer, porque minha família é uma família de luta. Se a gente fosse resgatar desde o passado, ia ter que buscar experiências políticas de muito longe. Tudo isso me constituiu, mas prefiro falar apenas de mim, das minhas escolhas conscientes. Estou um pouco distante da minha família...

Comecei no MST, vivi um tempo no MST e foi uma das melhores experiências da minha vida. Acompanhei uma ocupação de terras por pessoas que eram realmente da terra, que nasceram na roça, agricultores de verdade. O meu finado avô era dali, o meu bisavô era dali, o meu pai era dali, meu tio era dali. Assentamento Oziel Alves, no centro-sul do Piauí, e ali quem não é primo é irmão, com exceção de cinco famílias que vieram do Pernambuco.

É muito engraçado, passei muito tempo aqui em São Paulo e minha vida era essa: lutar por justiça. Hoje, particularmente, se eu falar para você que não luto por uma melhor condição financeira estarei mentindo. Hoje luto mais pela questão financeira, por causa da minha esposa, mas se não fosse isso, seria apenas luta pelo povo, luta por justiça social... Ainda sou comprometido com essas causas, sempre serei, mas agora a prioridade é o bem-estar da Laura, que conheci também na luta e que tem os mesmos princípios e ideais que eu.

No meio do povo também conheci esse cara, o Marcos, que está a meu lado. Ele era um latifundiário dentro do acampamento Chico Mendes, em Taboão da Serra. Chegou, cercou um monte de terreno para ele, para a família, para o cachorro, para o gato, para o papagaio...

Se a gente for explicar uma ocupação, o porquê, o motivo de sua existência pode parecer que não tem motivo algum, que tem gente lá com os mesmo interesses dos capitalistas, dos especuladores imobiliários. Se for assim não há motivo para ocupar terra de ninguém, mas se a terra é de ninguém, então é nossa! Se não é de ninguém é nossa, se é nossa a gente vai ocupar, agora se a gente vai ocupar uma coisa que é nossa, por que reproduzir o mesmo sistema? Porque um pegar dez centímetros e o outro cem metros? Foi isso que aconteceu com esse infeliz! Mas ele estava ingressando no Movimento, ainda não entendia as coisas. Agora o Marcos já aprendeu. 
Quando vi aquele monte de terreno que ele demarcou, desci a mão, arranquei a fita e falei: “você não precisa de tudo isso, isso é para quem estiver precisando!”. Ele tentou se justificar: "Esse é da minha mãe, esse é da minha irmã, esse é da minha outra irmã, esse é do meu cachorro...”. Brigamos e ele acabou ficando só com um pedacinho. Cercou e ficou lá dentro, bravo, uma fera, cuidando. Nessa época estava passando a novela América, que tinha um boi bravo, chamado "boi bandido", que vivia preso no pasto. Transferimos esse nome para ele. Boi Bandido.

No Chico Mendes também conheci Ana Terra, que chamo de Terrinha, como sinal de amizade. Já fomos confundidos com qualquer coisa: amigos, namorados, o diabo. A gente conversava muito sobre o mundo, sobre a cidade, sobre a ocupação, mas muitas coisas que disse para ela, hoje discordo. Discordo das minhas próprias palavras, porque sou meio confuso e porque o tempo passa, as coisas mudam.

Hoje estou fora da militância, ou melhor, estou fora do Movimento. Isso não significa que esteja fora da militância, significa que estou fora da entidade, do MTST porque estou precisando de tempo para pensar e porque as coisas estão tomando um rumo que não concordo. Apesar de tudo, depois de 17 anos de luta, ouvi, dentro do MTST uma das melhores frases que ouvi na minha vida. Foi dita por um companheiro, o Punk, quando esteve acorrentado em frente a Câmara Municipal. Ele disse: "Não basta o Leninismo, não basta o Marxismo, não basta Pragmatismo nem nenhum Letrismo se não tiver Humanismo”. O que é que está faltando entre nós? Humanismo. Falta o próprio ser “ser”, existir plenamente, com consciência, com liberdade, com paixão.

A hierarquia, a forma de organização do MTST, o personalismo está prejudicando as relações humanas e a possibilidade de "ser" das pessoas. Personalismo é o grande problema. Fidel está cometendo esse erro, concentrando a revolução na figura dele, e não só ele: Marighela errou, Che errou, Hugo Chaves está fazendo a mesma coisa e nós vamos errar, mas não precisa ser assim. 


\section{Laura}

\section{“Dessa luta não desisto, vou até o fim, pode dar o que der!”}

Fiquei sabendo da ocupação que teve no Valo Valho, mas não conseguia me decidir a ir para lá. Em uma semana dizia: “vou!” Na outra dizia: “não vou!”, até que um dia Lady e eu decidimos ir para aquele terreno, para aquela ocupação, para aquela luta e estamos até hoje.

A gente estava passando por dificuldades, até então morávamos com as nossas mães, mas não dava certo, a gente queria liberdade de sair e não podia. Saímos de casa, passamos um tempo pagando aluguel, quando a gente estava empregada, e morando em casa de amigos e amigas, quando perdemos o emprego. Nessa época surgiu esse negócio do Valo Velho e fomos para lá. Ao chegar lá vimos que já estava lotado, lotado, lotado, que não tinha nem como entrar em canto nenhum, aí a gente falou com uma mulher: "Moça, tem alguém nesse pedacinho aqui?” E ela disse: “Ai, aqui não cabe mais ninguém, aqui não cabe mais ninguém!” Lady e eu ficamos muito tristes. "Não cabe mais ninguém, perdemos porque ficamos enrolando para vir, perdemos!” Mas mesmo assim a gente não desistiu e no mesmo dia conhecemos um rapaz que nos ajudou. A Lady tem um amigo carioca que estava acampado lá, conversamos com ele e ele nos apresentou ao Marrom, que era do Chico Mendes, e disse que poderíamos ficar. Ganhamos um espaçosinho bem pequeno, compramos lona, passamos o dia todo para cavar três, quatro buracos! Ficamos desesperadas, quase chorando, tínhamos que terminar logo, senão o povo ia tomar nosso pedacinho de terra, aí graças a Deus conseguimos, conhecemos a maioria das pessoas da Militância, do Chico Mendes. Fiz amizade com todo mundo.

No dia que decidimos entrar na ocupação dissemos que não iríamos desistir! Decidimos que ficaríamos até o final, para ver o resultado e que não abandonaríamos nosso barraco em situação alguma, porque não adianta construir e deixar os outros cuidando. Graças a Deus estamos firmes na luta até hoje e nos casamos. Eu me casei com o Tonho, a Lady, com o Baiano e estamos vivendo em paz.

Esse terreno onde estamos aqui no Jardim Calú foi conquistado com muita luta, quase um mês de acorrentamento: Câmara, Prefeitura, Câmara, Prefeitura, chegamos inclusive a ir ao Palácio do Governo. Aconteceram tantas coisas que teve uma hora que eu entrei em desespero, comecei a chorar e falei: “Não vou agüentar mais isso, vou sair e não sei o quê...” Mas a Lady dizia: "Laura, tenha mais força porque a gente pode conseguir, a gente tem que ter força pra conseguir as coisas porque nada vem fácil!” As coisas aqui não são fáceis: alimentação, saúde, moradia, tudo é muito precário e somos nós que temos que cuidar de tudo porque não podemos ficar esperando pelos outros. Para cuidar de nossa saúde muitas vezes fazemos chás e acabamos acertando! Também produzimos nossa própria cultura: música, apresentações de teatro, dança. 
Sábado passado fizemos uma apresentação de dança afro que foi muito bem aceita. Tivemos apenas dois dias para ensaiar, então fizemos uma reunião, conversamos, conversamos. Quero agradecer a Michele, nossa instrutora. Ela disse: “Eu vou falar e vocês vão pensar!” A partir do que ela disse a gente conseguiu montar a apresentação. A partir das instruções seguimos em frente e não erramos um momento sequer! Dissemos que faríamos e fizemos. A gente tem que cumprir tudo o que fala!

A festa de sábado passado foi muito importante, porque era a comemoração da conquista desse terreno e das casas que serão construídas nele. Primeiro tivemos a Assembléia, onde essa notícia foi passada para todos. Todos aplaudiram e ficaram muito felizes! Depois da assembléia nosso grupo de dança fez a abertura da noite cultural. Dançamos duas músicas, todo mundo gostou, até hoje comentam. Nessa festa teve vários outros grupos de fora da comunidade, gente de Itapecerica, das outras ocupações, pessoas do Movimento, e até gente de Brasília. Cantamos, dançamos, não houve briga, não houve discussão, não choveu, só garoou um pouquinho, foi muito bonito, muito bonito! Não fiquei muito tempo porque vim dormir. Depois que fiquei “empolgada”, muito alegre, vim dormir, mas a festa foi da hora! Estamos aqui para o que der e vier e vamos alcançar nossos objetivos!

O dia que sair nossa casa vai ser o dia em que você vai me ver mais sorridente! Acho que vai ser apartamento, que vão construir prédios de apartamento, porque temos pouco espaço, mas preferia que fosse casa térrea, com quintalzinho, acho mais bonito. Não quero essa coisa de prédio, gente fechada em seus apartamentos, síndico chato. Acho que não pode ser assim, que cada um tem que ser responsável pela conservação do prédio, pela limpeza e que a solidariedade deve ser mantida. Vou querer ser vizinha da Lady. Conheço a Lady desde criança, nossas mães são comadres, mas às vezes elas discutiam por causa da gente, éramos terríveis! Íamos para todas as baladas juntas! Minha mãe achava que a Lady me levava para o "mau caminho". Como as brigas eram constantes e nós duas trabalhávamos, éramos maiores de idade, resolvemos alugar uma casa para nós, mas logo ficamos desempregadas e a coisa começou a apertar, até que um dia entramos na ocupação do Valo Velho, com o sonho de conseguirmos nossa casa, não só para gente, mas para nossas mães também, porque elas pagam aluguel.

O tempo que passamos no Valo Velho foi muito difícil, muitas vezes não tínhamos nem comida. A gente não tinha nada, nada, nada! Somente nossas roupas, então saíamos fazer o “corre”, procurávamos pessoas para nos apoiar, como meu padrasto, meu ex-padrasto e nossas amigas. Chegávamos já eram duas, duas e pouco da manhã, com um monte de bolsa, um monte de coisas. Íamos a pé de lá do Capão Redondo até o Valo Velho porque não tínhamos dinheiro para a condução. Foi uma época muito difícil e a Lady dizia: “Ai Laura, a gente tem que ganhar essa casa porque já não agüento mais andar!” 
Minha mãe não me apóia muito, no começo, principalmente, ela era bastante contra. Nunca foi no Valo Velho me ver, mas aqui na vila Calú ela já veio e disse: "Isso é lugar de doido! Você não precisa disso! Isso é um lugar de louco, você não tem medo de acontecer isso e isso com você?” Fica falando absurdos, não entende que minha luta não é só por mim, é por ela também. Venho lutando, estou lutando por causa dela e dessa luta não desisto, vou até o fim, pode dar o que der! Pode vir trator e nós estarmos aqui, pode vir Polícia, $\mathrm{GCM}^{44}$, pode dar o pau que der, nós estamos aqui e daqui não vamos sair, não importa o que a gente sofra!

Cresci com minha mãe, não conheci meu pai. Algumas vezes pensei em conhecê-lo, mas como ele não convivia comigo, foi impossível. Para mim era só minha mãe, ela era mãe e pai, sempre foi, e assim a gente foi convivendo.

Uma vez lá no Menininha teve uma ocupação da qual participei e me lembro claramente. Todo aquele povo que mora lá hoje é da época dessa ocupação. Eu tinha entre oito e nove anos, minha mãe trabalhava muito e mandou um homem construir um barraco para a gente, deu um temporal e o barraco caiu, porque era em um morro, nem deu tempo de tirar as coisas, foi geladeira, fogão, roupa, foi tudo. Só deu tempo de ela nos tirar, as coisas ficaram na lama, na inundação. Três vezes aconteceu isso no Menininha, a última vez quem fez o barraco foi minha mãe, e dessa vez ele não caiu mais, pode chover, chover, chover que não cai uma gota dentro do barraco. Assim a gente foi convivendo: minha mãe trabalhando muito, lutando muito para nos sustentar. Naquele tempo éramos cinco, agora somos sete, quatro mulheres e três homens. Começamos a estudar, mas eu, particularmente, dedicava a maior parte do tempo aos cuidados da casa e dos meus irmãos, apesar de ter uma irmã mais velha que também ajudava. Não tinha muita cabeça para estudar, tinha as preocupações com a casa, tinha que ajudar.

Assim a gente foi convivendo, até que minha mãe arrumou uma pessoa, o Barba, meu padrasto, a quem tenho muito amor. O apelido dele é Barba, mas o nome é Jazam. Ele foi o meu pai porque roupa era ele quem me dava, material de escola era ele quem me dava, carinho, amor, atenção era ele quem me dava. Tudo o que não tive desse pai que dizem ser meu pai o Jazam me deu. Meu pai biológico mora no Jardim Rosana, está tendo uma ocupação enfrente a casa dele. Tem uma favela enorme e mais para cima tem um terreno baldio, que ocuparam.

Na adolescência minha relação com minha mãe foi complicada. Minha mãe é... Ela é evangélica, muito rígida em seus valores e eu não tinha muito juízo. Era a época que havia aqueles conjuntos musicais com duas dançarinas, tipo É o Tcham, e meu sonho era ser uma dançarina como aquelas. Faltava aula na escola para ir dançar, ensaiava muito para um concurso que ia ter, fiz toda uma preparação, inclusive coloquei aplique nos meus cabelos, para parecer bem comprido e eu ficar mais bonita para o concurso. A menina que fosse escolhida ficaria

\footnotetext{
${ }^{44}$ Guarda Civil Metropolitana.
} 
famosa, dançaria em um conjunto importante, teria uma vida de princesa e aquele era o meu sonho.

No dia do meu grupo se apresentar minha mãe não me deixou ir ao salão de festas, fiquei desesperada, meus amigos ficaram desesperados e falei: “Ta bom, pode deixar!” Entrei no quarto chorando e fingi que ia dormir, depois saí de vagarzinho, olhei por uma frestinha da porta do quarto de minha mãe, vi que ela dormia e corri para o salão. Foi uma alegria conseguir chegar lá! Só que fiquei nos fundos, me concentrando, não fiquei dando voltas pelo salão, aí um amigo sentiu minha falta e a de meu irmão e foi em casa falar com minha mãe para que ela nos deixasse ir. Meu irmão ela tinha autorizado, mas eu não. Quando ela foi ao quarto e viu que eu não estava, deve ter ficado furiosa. Mandou esse meu amigo me avisar que ela estava indo me buscar de cinta! Mas aí eu já tinha dançado, me sentei e falei: “Quero ver!”. Em menos de cinco minutos foi avisado no alto-falante: "Laura, sua mãe ta aí fora, ela mandou dizer que ou você sai, ou ela entra”. Pensei comigo, ela vai entrar pela porta da frente e eu escapo pela dos fundos, chegando em casa a gente resolve isso, mas não vou passar vergonha na frente dos meus amigos nem na frente de estranhos, só que quando estava saindo ela estava me esperando, perto de umas motos. Tinha um monte de gente parada falando: “É hoje que a Laurinha apanha!” outras cochichando baixinho, tensas. Minha mãe não teve escrúpulo e me bateu até chegar em casa. Algumas pessoas diziam: “Isso mesmo Dona, desce a porrada!”.

Chegando a casa, achei que ela fosse parar com aquilo, mas não, me levou para o banheiro, trancou a porta e me bateu muito. Bati a cabeça no vaso sanitário, desmaiei, acordei, desmaiei de novo e ainda apanhando. Não sentia mais meu corpo, era tudo um inchaço e já nem sabia o que estava acontecendo, aí ela me colocou na cama para dormir e foi se deitar também. No outro dia cedo minha irmã chegou de uma festa e quando me viu, já no portão falou: “Quem foi? quem foi o filho da puta, animal que fez isso com você, que eu mato! Me fala quem fez isso com você, Laura, que eu mato!” Meus olhos estavam estourados de tanta porrada, eu mal conseguia enxergar, minha fronte estava cortada e o resto do meu corpo todo inchado, cheio de vergões e hematomas. Os vizinhos me olhavam e choravam, queriam chamar a Polícia e o Conselho Tutelar para levar minha mãe, mas não deixei. Apesar de tudo, não queria ver minha mãe presa. Quando falei para minha irmã que tinha sido nossa mãe que tinha feito aquilo em mim, ela me abraçou e começou a chorar e dizia que não era, que não podia ser, que nossa mãe nunca faria uma coisa daquelas.

Passei vários dias muito doente, sentindo muita dor e meu olho esquerdo até hoje é desse jeito: cheio de veias. Sofri muito, senti raiva, vergonha, mas nunca ódio. Perdoei minha mãe e sei que no fundo ela estava certa, que só queria o bem para mim, mas nunca consegui 
dizer isso para ela, mesmo passado todos esses anos nunca consegui sentar ao lado dela e conversar sobre o acontecido.

Nossa relação melhorou, ficou difícil de novo e a gota d’água foi quando coloquei um piercing no umbigo. Aí ela me tocou de casa, me mandou para a casa do meu pai, que eu nem conhecia, que tinha visto umas poucas vezes apenas.

Esses dias fui visitar umas amigas próximo a onde ele mora, vi o acampamento. Ele estava lá, a gente começou a conversar e soube que ele se separou da mulher e arrumou outra, só que assim: a gente nunca se deu, nunca! Em primeiro lugar: ele é “alemão”, tem os olhos verdes e um monte de preconceitos. Quando fui morar lá ele bebia e até sem estar bêbado dizia que não era filha dele porque sou negra. A família dele não aceita preto. Ele perguntava o que eu estava fazendo na casa dele, comendo no prato dele sem saber se era realmente filha. Não me aceitava, nunca me aceitou e vivia mandando eu pegar minhas coisas e sair fora. Para onde ir?

Mais uma vez relacionamento difícil: como chegar nele e dar um abraço do fundo do coração? Dizer para ele que o amo sem nem o conhecer? Sem nunca ter convivido com ele? Quando o conheci eu era novinha, tinha uns dez anos. De vez em quando ele ia lá em casa e nos dava dinheiro, só que assim: para a minha irmã mais velha, que é filha dele também, ele dava sempre R\$: 50, 00, para o meu irmão $\mathrm{R} \$$ : 50, 00 e quando chegava minha vez ele me dava apenas dez, não sei se é porque eu sou negra... Minha irmã é um pouco mais clara do que eu, meu irmão já puxou para ele, tem os olhos claros, entendeu? Mas isso é porque ele não se batia comigo, não gostava de mim e eu sempre soube disso, desde pequena. Sempre falava: "olha, ele não gosta de mim, me detesta, sou preta, ele é branco”.

Meu pai quer passar uma imagem de que é melhor do que eu, melhor do que a minha família, ele me detesta! Um dia cheguei a perguntar para a minha mãe se ele era mesmo meu pai, ela garantiu que sim. Fui conhecendo-o pouco a pouco, mas nunca gostei dele por causa do jeito de me tratar. Se ele me tratasse com amor da mesma forma iria tratá-lo, só que não, sempre fui rejeitada. Quando ele ia comprar roupa para a minha irmã, eu dava o número, porque eles nunca me levavam e eu também não fazia questão de ir porque não me sentia bem. Minha irmã comprava tudo do número dela, sapato, roupa, se arrumava todinha porque ele dava de tudo para ela, e para o meu irmão também. Para mim ele trazia o número do sapato menor, para não servir, trazia uma roupa que ficava caindo em mim, tudo para o meu irmão e irmã era certinho, nada de trocar, nunca precisou trocar.

Nunca senti que ele me deu nada com amor, sempre me pareceu uma obrigação. Fui convivendo com isso, sempre coloquei isso na cabeça e fiquei mais revoltada quando minha mãe me mandou para lá. Logo que lá cheguei, fazia as coisas, aqui está bagunçado, mas eu sempre gostei de tudo arrumado, tudo, tudo! Não gosto de ver nada fora do lugar, gosto de tudo bem 
arrumado, tudo limpo e cheiroso, e lá, no início, era a maior bagunça! Não tinha como conviver ali com um monte de gente e um monte de bagunça, então resolvi dar uma faxina enorme, arrumei tudo. Quando ele chegou do serviço falou assim para mim: “isso aqui é a minha casa?”

Não limpei para provocar a mulher dele e nem ninguém que morava lá dentro, limpei porque estava sujo demais. A mulher dele achava que eu estava fazendo aquilo para provocá-la, como quem dissesse “pô, você é porca!”. É do meu feitio fazer as coisas, andar arrumando e também aprendi a ser assim trabalhando em casa de família, tive uma patroa que me ensinou muitas coisas. Então, sentia-me incomodada com a forma como os serviços domésticos eram feitos na casa de meu pai. A mulher dele lavava as roupas junto com os panos de chão. Era galinha, era cachorro... Ela catava reciclagem, mas eu não sabia. Não tenho nada contra esse tipo de trabalho, mas acho que o que você pegar na rua tem que ter um lugar certinho para guardar, não pode deixar espalhado pelo quintal. Não sabia, peguei as reciclagens, joguei no lixo e o lixeiro passou. Quando ela chegou e sentiu falta das coisas começou a me xingar. Disse que eu estava fazendo aquilo para provocá-la, que ela não gostava de mim e que eu ia sofrer muito nas mãos dela porque ela sabe provocar mais ainda. Pedi desculpas, falei que não sabia, pois tinha acabado de chegar, tinha uma semana.

Limpava a casa, fazia comida sempre no mesmo horário, a casa estava sempre limpa e meu pai foi gostando daquilo, mas depois se mostrou quem realmente era. Passou uns quinze dias sem beber, quando voltou a beber começou a me rejeitar, colocava apelidos que eu não gostava, me machucava com várias coisas que falava. Pensei comigo: "Vou ter que arrumar um emprego de qualquer jeito porque seu eu tiver um emprego não vai ter como ele dizer que estou na casa dele de favor, comendo de uma comida que só ele coloca”. Aí comecei a trabalhar em feira, com meu cunhado, comecei a ganhar meu dinheirinho e tudo o que queria comprar, que pedia para a minha mãe e ela não podia me dar, eu comprei. O engraçado é que se minha irmã pedisse qualquer coisa ela dava, mas para mim não.

Minha mãe fez a festa de quinze anos dela, ela queria um aparelho de som da maior potência e ganhou. No dia do aniversário, depois da festa minha mãe chegou com o som. Quando fiz quatorze anos pedi essa festa para minha mãe, só que o meu desejo era ter uma prancha de cabelo e um celular, um dos dois ela teria que me dar de presente, foi uma coisa que ela foi enrolando e não me deu, mas por eu ter conseguido trabalhar na feira, lá no Rosana, pude comprar com meu próprio dinheiro. Inclusive comprei dois celulares, um depois do outro. Fui comprando tudo o que queria, arrumando meus cabelos, me cuidando, e assim fomos convivendo.

Trabalhava de segunda a segunda, nos finais de semana eu sempre chegava cedo, porque em final de semana a feira termina cedo. Cheguei em casa e encontrei meu pai bêbado, 
com uns amigos e ele falava: "Esse pau preto que vocês estão vendo aí diz que é minha filha. Parece comigo?” Os amigos dele disseram: “Ah, parece sim, apesar de morena...” Só que eles não falavam no mesmo tom que ele, em tom de raiva e escárnio. Falavam: “Apesar de ela ser morena, os olhos, as coisas assim parecem. Ela parece muito com você, sim”. Ele dizia: “Eu não acho, é preta, tenho nojo de preto, não gosto de preto”. E continuava: “Pega uma cerveja na geladeira minha escrava, você não é minha filha! Acho que você deveria ter vindo no tempo dos escravos, porque você merece ser uma escrava”. Falava isso para mim e quero deixar de ser eu se isso não for verdade, não quero ganhar nada de tudo o que lutei aqui dentro do acampamento se estiver mentindo!

Ele falava tudo isso para mim e um pouco mais. Teve uma vez que cheguei do emprego e as meninas me chamaram para sair, mas disse que não iria porque estava muito cansada, ele levantou bêbado no meio da noite e falou: "Levanta vagabunda, aqui não é para você morar, não quero você na minha casa!” Me jogou de cima do beliche, quando caí machuquei as costelas, que ficaram doloridas várias semanas e aconteceu uma coisa que jamais imaginei: brigar com uma pessoa que dizia ser meu pai! Ele me deu um soco, caí e ele foi me jogando para fora, me batendo, aí foi onde vi um cabo de vassoura e comecei a bater nele também. Falei: "Você não vai me bater porque o tempo que morei com minha mãe não vivi com você, mas agora você está demonstrando quem você é! Porque para você fazer isso com uma filha...” Aí ele falou: "Você não é minha filha, tenho nojo de você. Pega as suas coisas e fora da minha casa!”

Perguntei a mim mesma: “E agora, para onde vou? Para onde vou? Vou morar debaixo da ponte?” Para a casa da minha mãe não vou mais, porque sofri muito lá.

Depois de eu sair no tapa com meu pai ele foi deitar, mas antes me deu um soco na boca que fez sair sangue e meus olhos ficaram roxos por vários dias. Minhas coisas, do jeito que estavam no guarda-roupa, ele pegou e jogou no quintal sujo de lama. Tudo o que consegui comprar trabalhando ele jogou na lama. Fui pegando, chorando, revoltada da vida e me perguntava por que eu tinha nascido para sofrer tanto.

Nesse tempo eu tinha um namorado, para quem sempre contava como era minha vida na casa de meu pai, e ele dizia: “A partir do momento que você não agüentar mais você vem morar mais eu, minha mãe não vai ligar, ninguém vai ligar”. Nesse dia o procurei, comecei a chorar, falei que tinha brigado com o meu pai, falei tudo, só que ele tinha brigado com a mãe dele também, então não tinha como me levar para a casa dele. Fui para a casa de uma amiga, de madrugada. Ela era casada, tinha dois filhos e trabalhava fora, então fiquei cuidando das crianças para o casal. Depois de cinco meses minha mãe mandou meu irmão mais velho e a Lady me buscar porque saiu uma história lá no Piauí que eu estava grávida. De São Paulo ao Piauí, imagine a distância. Ela mandou me buscar só por causa do boato da gravidez, aí falei: "Uai, 
então vamos ao posto de saúde, vou fazer os exames e mostrar se estou ou não estou grávida”. Ela falou: "Você não vai mais para aquele lugar de vagabundos, aquele lugar que só tem nóias!” Chegou até ela comentários de que eu estava namorando com altos bandidos. Ela simplesmente não sabia o quanto eu estava sofrendo por morar com uma pessoa que...

Voltei a morar com ela, brigamos, retornei para a casa do meu pai e assim foi até o dia em que falei: “Estou trabalhando - naquela época eu trabalhava no farol - vou alugar uma casa!” Aí a Lady, minha vizinha, que também tinha problemas com a família, a mãe é alcoólatra, decidiu ir comigo. Moramos de aluguel por um tempo, enfrentamos várias barreiras, até que ficamos desempregadas e fomos para a ocupação do Valo Velho. Hoje, graças a Deus estamos aqui.

Houve um tempo em que morei no Piauí. Minha mãe vendeu a casa aqui do Jardim Menininha e a primeira coisa que fez foi comprar um terreno no Piaú, para construir uma outra. Havia, na verdade, dois terrenos, um para fazer a casa e outro para fazer plantações. O dinheiro não foi suficiente e a casa ficou construída pela metade. Ela teve que vir embora com a minha irmã caçula e nos deixou lá, com minha irmã que é casada, só que com o meu cunhado eu não me dava bem porque aconteciam “as coisas” debaixo do nariz da minha irmã, eu falava para ela e ela não acreditava, entendeu? Eu falava: “Olha, ele está te traindo, já cheguei a ver”. Ela virava para mim e falava: "Eu acho que você está a fim dele, você está mentindo! Por que você se preocupa tanto com ele?” “Eu não me preocupo com ele, me preocupo com você, porque estão acontecendo coisas que eu não quero que aconteçam com você”. E aí foi indo, foi indo, vai briga de novo!

Saí da casa de minha irmã e fui morar na que minha mãe havia deixado sem terminar. Havia as paredes, a metade estava sem telhado, não tinha portas e nem janelas. Peguei os móveis da minha mãe e levei para lá, coloquei um pano na porta, peguei meus irmãos e nos mudamos. Sem porta e sem janela, dia e noite vivendo naquilo, andando não sei quantos quilômetros, derrubando árvore, rachando lenha, carregando na cabeça. Sofri muito lá, sofri, sofri, sofri. Minha mãe mandava dinheiro na conta do meu cunhado, ele fazia compra, mas só nos dava o arroz, o feijão, fubá e óleo. Para eles iam os danones, as bolachas, coisa que faziam falta para nós, crianças. Meus irmãos eram mais crianças. A gente só comia cuscuz, arroz e feijão, cuscuz, arroz e feijão, não tinha outra coisa e fui convivendo com isso.

Arrumei uma pessoa lá, um homem casado, mas não sabia que era casado. Um ano e cinco meses depois, quando já estava de volta a São Paulo vim saber que a esposa dele era prima da minha mãe. Aconteceu o que aconteceu, sofri muito com ele lá, era completamente apaixonada, para mim era Deus no céu e ele na terra! 
Discuti com família, parei de falar com toda a minha família do Piauí, todo mundo começou a me odiar, a falar que eu não prestava, só que até então eu não entendia, nunca ninguém chegou e falou: “Olha, estou falando isso de você porque você está com tal pessoa que é assim, assim, assado”. Eu tinha acabado de chegar lá, bati os olhos nele e ele em mim e aconteceu o que aconteceu. Depois que soube que ele era casado sofri mais ainda. Chegou um tempo em que eu vivia bêbada, se chegasse alguém e falasse: "Laura, hoje você está boa para a gente conversar?” Eu dizia: “Não”. Não sei onde tinha arrumado dinheiro, de onde tinha saído a bebida, cheguei a ter ânsia de vômito, sujar o salão, quebrar tudo, a bagunçar tudo, sabe? Eu era uma pessoa que não prestava mais para nada, se o mundo acabasse eu podia ir junto, não prestava. E assim nós fomos convivendo.

Devido a esses problemas minha mãe mandou me buscar e foi onde aconteceu tudo isso com pai, com mãe, e eu fui vivendo, namorando, namorando, porque nunca achava uma pessoa que desse certo, que falasse assim: "Você vai acabar com tudo isso, você não vai sofrer mais porque eu to aqui. Agora você arrumou um homem, você não arrumou um vagabundo e nem um qualquer para fazer você sofrer”.

Graças a Deus o Tonho entrou na minha vida. A gente se conheceu no Valo Velho, brincávamos muito e ele vivia dizendo: "Eu te amo, eu te amo, eu quero ficar com você”, só que eu não acreditava, dava risada e falava: "Eu? Não meu irmão. Arruma outra pessoa porque eu não te quero não, te quero sim, como um grande amigo. Te considero como um irmão, então acho que não tem como”. Nunca aconteceu nada entre nós dois. No ato do Taboão, em frente à Prefeitura, bateram nele, machucaram e ele disse que ia embora, que estava cansado, aí comecei a chorar, só que não entendia o porquê daquele choro. Hoje penso que naquela época já sentia alguma coisa por ele. Falei: “Tonho, não vá, você é a única pessoa que tenho aqui, a única pessoa que considero. Eu gosto muito de você, se você for não vou ter mais ninguém aqui para me ajudar. Eu nem construí meu barraco ainda, nem tenho barraco”.

Tonho e eu fomos convivendo, convivendo, teve um dia que ele me ajudou a construir o barraco, mas eu não tinha todos os materiais e nós dormimos no relento, olhando para as estrelas. Ali foi onde tudo aconteceu e ele disse que queria viver comigo. Falei que não dava, mas de tanto ele insistir e a gente ir convivendo, percebi a pessoa boa que ele é, entendi que ele não ia se desfazer de mim, ficar comigo e sair falando, brincar com a minha cara. Ele tem 33 anos, eu tenho 19. Falei para mim mesma: “Bom, vou arriscar, vou colocar a mão no fogo mais uma vez”. Deu certo, estamos juntos até hoje, um chora, o outro chora, um empresta o ombro ao outro e assim nós fomos convivendo.

Deus soube colocar o Tonho na minha vida. Jamais pensei que fosse colocar uma pessoa que me aturasse do jeito que sou, bom, eu também o aturo do jeito que é e tenho esperança de 
que a gente vai viver juntos por muitos anos. Não quero saber o que os outros falam: “A, ele é velho, ai, como você tem coragem?” Porque já chegaram até mim e falaram: “Olha, você ta com ele sabe por quê? Porque ele te ajudou a fazer o barraco e está te sustentando. Você acha que vai conseguir ficar com ele? Ele é um alcoólatra! Laura, você é muito nova para isso, você não merece isso". Simplesmente virei para a pessoa que disse isso e falei: “Eu reconheço que o Tonho é uma pessoa boa e vou continuar lutando por ele. Se ele é alcoólatra, um dia vai parar de beber porque sou mulher suficiente para fazer isso!” Graças a Deus estou conseguindo.

Quando os apartamentos saírem vamos morar juntos. Cada um de nós tem um cadastro para pegar um apartamento, na época não nos conhecíamos, não sabíamos que íamos viver como casados. Talvez ele dê o apartamento dele para a mãe, mas não sei por que uma vez ele construiu uma casa para ela e ela não aceitou.

O Tonho e a família dele, assim como a minha, é do Piauí. A mãe dele o deixou ainda pequeno e veio para São Paulo tentar a vida. Tonho é de Teresina, já eu nasci aqui em São Paulo. Ele sofreu muito porque a mãe não dava atenção a ele, não dava carinho. Ele trabalhava muito na roça, depois começou a estudar, se inscreveu no Exército, começou a trabalhar, trabalhar, trabalhar, foi juntando dinheiro e mandando para a mãe. Ele tem três irmãos aqui e uma no Piauí, que mora sozinha. Tonho foi construindo casa, construindo coisas, mas nenhuma para ele e foi se sentindo uma pessoa revoltada, porque nunca teve a atenção da mãe. Ela nunca falou: "Filho, passei essa blusa aqui para você porque você está cansado, você trabalhou muito”, ou: “Fiz essa comida para você porque sei que você gosta”. Ele sempre se virou sozinho em tudo.

Hoje ele fala que sou a felicidade e a família dele. Um dia desses, ele estava chorando porque a mãe dele não liga para a gente, ninguém da família dele vem nos visitar e eu disse: “Já que você acha que não tem família da parte do seu sangue, eu estou aqui! A gente vai lutar, vai ter a nossa casa, vou trabalhar, você vai trabalhar e a gente vai ter esse filho, vai ter uma família! Já que você não tem família vou ser sua família e você vai ser pai. Não sei que dia, mas você vai ser pai, vai ter quantos filhos quiser, se é por falta de família que você está triste, vou ter muitos filhos para você e para mim”. Ele ficou muito feliz e graças a Deus vai tudo bem. Quanto à casa que ele construiu, ele a deixou para a irmã e veio para São Paulo. Trabalhou muito aqui, foi morando de aluguel, sofrendo, sozinho no mundo, mas nunca dependeu de ninguém. Ele dizia: “Não quero depender de família, tenho medo de família jogar as coisas na minha cara, só vou depender de mim mesmo”.

Depois ele conheceu o Movimento, se tornou militante, sofreu muito também com esse negócio de ocupação, mas está aí e é feliz ao meu lado. Tenho orgulho disso! Também sou muito feliz ao lado dele porque ele é uma pessoa maravilhosa! 


\section{Maria da Paixão}

\section{“Tenho muita saudade da minha terra e do meu povo"}

Acho importante esse tipo de trabalho baseado na história de vida de pessoas como eu, porque até hoje o que está na história, nos livros e é ensinado para os estudantes no colégio é que o Brasil foi construído por homens brancos de origem européia. Cadê as mulheres nessa história? Cadê os negros? Por que os índios não aparecem? Não somos a minoria - como eles falam e querem fazer a gente acreditar - e esse país foi feito com o nosso trabalho, com os nossos esforços e isso precisa ser conhecido e valorizado! A gente tem uma experiência de vida para contar, uma experiência de sobrevivência e trabalho. No meu caso não foi uma experiência muito boa.

Vim do “norte” há muitos anos, sou piauiense. Na primeira vez que vim para São Paulo eu tinha dez anos. Cheguei aqui, não conhecia nada, nada, nada. Fui morar na Vila Anastácio, com uma tia minha e comecei a trabalhar ajudando ela. Minha tia trabalhava para três empresas grandes, tinha uma pensão e servia refeições para 130 homens, empregados dessas empresas. A gente fornecia café da manhã e almoço. Para os que moravam na pensão também servíamos janta. Muitos daqueles rapazes moravam na pensão.

Era muito trabalho e era muito frio em São Paulo naquela época. De manhã cedo, quando você levantava caía gelo, a água da torneira ficava congelada. A gente levantava quatro ou cinco horas da manhã, e eu ainda era pequena, dez anos de idade. Assim fomos convivendo.

Nossa vida lá na roça também era muito difícil. Nós éramos muito pobres, morávamos em uma casinha coberta com palha de coco, mas não chovia dentro. Era uma casinha feita de varas, parecida com uma cabana de índio, e ali meu criou a nós todos, trabalhando na roça.

Quando peguei certa idade minha tia chegou e me convidou para vir para São Paulo, pediu para meu pai deixar-me vir trabalhar com ela. Fiquei ansiosa para conhecer São Paulo, porque ouvia falar muito sobre essa cidade pelo rádio. Naquela época não tinha televisão. Meu pai tinha um rádio velho, bem grande, que era ligado todos os dias às seis horas da tarde para a gente "assistir" a reza. Hoje, sou evangélica e não falo reza, falo oração. Meu pai ligava aquele rádio para ouvir as notícias também, para saber o que acontecia no mundo e aquele rádio velho falava, falava, falava até as oito horas da noite. Depois ele desligava, acendia uma fogueira lá fora e ali era a nossa convivência de todos os dias.

Vim para São Paulo com minha tia, morei com ela quatro anos da primeira vez, fiquei na pensão com ela, servindo comida àqueles rapazes, era tanta comida meu Deus, tanta carne, tanta coisa! Nós trabalhávamos dia a dia, de domingo a domingo, sem parar. Quando estava com os meus quatorze anos voltei para a roça, voltei para a casa dos meus pais e ali fiquei mais um ano e 
pouco. Depois que completei quinze anos minha tia me chamou de volta, porque estava precisando de mim para ajudar na pensão. Voltei novamente para São Paulo, desta vez mais madura, com um objetivo: assim que completar 18 anos arranjar um emprego remunerado e comprar uma casa para meu pai. Voltei e fiquei trabalhando com ela até completar dezoito anos, quando cheguei à maioridade falei: “Tia, agora sou maior de idade, vou tirar meus documentos porque preciso trabalhar. Já sei cozinhar, já sei limpar uma casa, agora preciso trabalhar para tirar minha mãe daquela situação em que ela está!” Ela disse: “Tudo bem, minha filha, eu não posso fazer nada, você já é maior, você sabe o que faz”. De Vila Anastácio, em Osasco, fui para o Campo Limpo, para a casa de uma irmã porque já tinha uma irmã que morava aqui. Ela me arrumou emprego em casa de família. Graças a Deus trabalhei bastante tempo e consegui dar a casa que o meu pai queria, construí a casa do meu pai, com sete cômodos, enorme, lá no Piauí, no sítio, na roça.

Eu mandava dinheiro para a construção da casa todo mês, e olha como era engraçado... Hoje nós temos Banco de toda a espécie para depositarmos um dinheiro, transferirmos para o número da conta desejado, automaticamente, mas naquela época não tinha. Naquela época a gente escrevia uma carta e mandava o dinheiro junto com ela, quando achava alguém para levar. Olha o que eu fazia: pegava um envelope, colocava uma quantia, nem me lembro mais que dinheiro era, porque hoje a gente trabalha com Real. Colocava uma cédula dentro do envelope, dobrava uma folha de caderno umas três, quatro vezes em cima daquela nota de dinheiro, colocava no envelope, ia aos Correios, registrava aquele envelope, colocava o destinatário para uma pessoa retirar, nos Correios, e levar até meu pai lá na roça! Era muito estranho, né? Hoje é diferente.

As pessoas eram muito solidárias, entregavam direitinho, não roubavam um centavo! Até hoje o povo do Nordeste tem muita honestidade. A palavra daqueles homens e daquelas mulheres da roça é rígida, não muda!

Quem recebia minhas cartas e entregava para meu pai era um senhor chamado José Barbosa, que infelizmente já faleceu. Ele recebia minhas correspondências e mandava aqueles açougueiros, que trabalhavam de cavalo, de jumento, lá para o interior e orientava-os: “Fala para o compadre Raimundo que tem uma carta de Paixão para ele aqui” Meu nome é Maria da Paixão, mas me chamam de Paixão. Seu José Barbosa ia aos Correios, recebia, assinava aquele envelope, achava que era uma carta comum, mas meu pai abria e era dinheiro, e eu mandava apenas duas palavras escritas: “Compre bloco”. Naquela época nós não chamávamos bloco, chamávamos adobe. Dizia para ele: “Compre o adobe para fazer a casa” e ele comprava. Quando terminei de mandar o dinheiro para comprar o material falei: “Agora arrume o pessoal para levantar a casa, que vou mandar o dinheiro para pagar a mão-de-obra”. Sabe como eu conseguia juntar esse 
dinheiro? Minha tia não me pagava nada, mas daqueles 130 homens que tinham naquela pensão, muitos, digamos que uns 30 ou 40 moravam na pensão, porque era uma pensão bem grande, tinha vários quartos e cada quarto tinha quatro camas, com beliche. Eu lavava roupa para eles. Aquele dinheiro que mandava para a construção da casa de meu pai, era de roupa que eu lavava. Aí, quando peguei minha idade e fui trabalhar fora comecei a mandar um pouco mais: “Agora choveu dinheiro, agora está melhor a situação!”. Minhas patroas me ajudavam muito, me davam roupas, davam roupas para eu mandar para eles e fui conseguindo. Devagarzinho aquela situação foi melhorando e assim fomos convivendo...

O meu pai, coitado... Lembro que a melhor roupa dele - que era de vestir para ir para a cidade - era uma camisa, só que do tecido dela mesmo havia bem pouco. Tinha vários e vários pedaços de outros panos que minha mãe colocava, vários remendos. Ele vestia aquela roupa e recebia muita crítica porque a família da minha mãe era melhor de vida. Criticavam minha mãe por ter se casado com meu pai. Meu pai era pobrezinho, vivia naquela situação e eles humilhavam muito a gente por causa disso. Ainda hoje tem um pouco disso, mas agora a gente cresceu, sabe se defender.

Minha mãe lavava aquela roupa para meu pai, aquela calça com um milhão de remendos, coitado, do tecido da calça só tinha mesmo o corredor e a costura, o resto era só remendo. Aquilo me angustiava muito, sofria muito com aquela situação! Quando comecei a trabalhar em casa de família, minhas patroas perguntavam como eram meus pais, minha família, e a gente começava a se tornar amiga. Elas ficavam com dó da situação e começavam a mandar coisas para minha mãe, para meu pai e meus irmãos, mandavam roupas. Somos oito ao todo, três mulheres e cinco homens. Sou a caçula.

Meu pai construiu a casinha, e quando estava pronta, de telha nova, disse: "Minha filha, não precisa mandar dinheiro para eu comprar cimento não, porque cimento é luxo. Vou aterrar ela”. Não tem aquelas casinhas de chão de terra, de barro? Fica bem firme. Nós fizemos um serviço desses esses dias, construí uma casa lá no Piauí esses tempos, de chão batido, bem firme, bem bonito. Meu pai falou: "Filha, não precisa mandar dinheiro para cimento, não, arruma dinheiro para você se cuidar porque eu já aterrei e está bom”. Mas falei: "Vou mandar sim porque mamãe não agüenta fazer o serviço sozinha, é muita coisa, não tem água, água é difícil e com piso de cimento, passou um paninho já tá limpo, não precisa ta varrendo toda hora”. Consegui mandar o dinheiro para meu pai fazer o pisinho da casa, ele fez, colocou o reboco - lá o reboco é feito de barro mesmo, e ficou bonitinha a casa da minha mãe. Em comparação com onde ela vivia, passou a morar em um palácio!

A casa somente eu ajudei a construir, meus irmãos que moravam aqui em São Paulo enviavam dinheiro para comprar outras coisas, como alimentos, porque às vezes não tem inverno 
e quando isso acontece, as pessoas do sertão do Piauí passam muita necessidade, até hoje. Lá eles vivem da agricultura, não tem firmas, não tem empresas, não tem emprego. Aqui em São Paulo a gente encontra um serviço de faxineira aqui, diarista lá, arrumadeira em casa de família, mas lá é muito difícil você encontrar um trabalho. As pessoas vivem das plantações, da lavoura. Se não tem inverno não tem colheita. Inverno que eu falo é chuva. Se não tem inverno, a lata de óleo passa a custar R\$: 4,00 ou R\$: 5,00, o feijão, o arroz, as coisas todas aumentam de preço. É um custo de vida alto e não se tem como pagar, fica difícil sobreviver. Quando não tinha inverno era uma situação muito difícil, era uma tristeza!

Meus irmãos José de Anchieta e Maria das Graças já eram casados nesta época, tinham a família deles para se preocupar, mas meu irmão que era solteiro ajudava muito meu pai. Meu pai falou: "Paixão já está mandando dinheiro para construir a casa, então vocês arrumam aí para outra parte”. Lá eles fazem as portinhas pela metade, é diferente daqui, só abre a parte de baixo.

Pensei: "Fiz a casa para minha mãe agora vou fazer a minha vida”. Continuei trabalhando e lá na casa do seu Miguel, em Pinheiros, encontrei um pedreiro. Ele estava trabalhando para o seu Miguel, em uma construção. Seu Miguel era advogado. Conheci esse pedreiro, gostei dele, ele de mim e juntamos os trapos. Fomos morar juntos. Nessas alturas já tinha meus 22, 23 anos, fui morar com ele e comecei a ter meus filhos. Falei: "Meu Deus, vou começar a ter minha família e me responsabilizar por alguma coisa na minha vida”. Tive, desse casamento, a Luciana, que foi a primeira, o Felipe, que está com 22 anos e a terceira foi a Laura.

Não deu certo, o pai deles não tinha juízo, era muito novo, não tinha responsabilidade. A vida dele era dançar em festa, saía sexta e só voltava segunda, com a camisa nas costas. Eu falava: “Genival, cadê o leite dos meninos?” E ele: “Só semana que vem”. Passar a semana inteira com fome para comer na próxima semana? É um tonto, né? Tive muita luta porque os meninos começaram a nascer e eu não tinha quem cuidasse. Precisava trabalhar, mas como Laura deu muito trabalho, era muito pequena, ninguém queria cuidar dela porque tinha medo. Era prematura, nasceu com menos de sete meses. Felizmente encontrei um trabalho em Pinheiros, na Avenida Deputado Lacerda Franco, em uma empresa chamada Construtora Ipê, e meus patrões eram cinco - montaram um quartinho em uma varanda, colocaram um bercinho e me deixaram ficar com Laura perto de mim. Todos os dias levava a Laura para trabalhar comigo, ela não chorava, o chora dela era um "hum” de tão fraquinha que era, e quando emitia esse som, parava tudo para cuidar dela. Muitas vezes os patrões iam embora e deixavam o escritório aberto para eu ficar até terminar o serviço e sair com Laura. Chegava à casa nove, dez horas da noite. Hoje, graças a Deus Laura está aí, com 19 anos, vai fazer 20 no dia quatro de Abril, e daí por diante minha luta foi essa: trabalhar e criar meus filhos. 
Tenho sete filhos, não me arrependi. Tenho também um neto de quatro anos que se chama Johnatan, está lá no Piauí, é o filho da minha filha mais velha. Tem Laura, que agora está grávida, mas os outros rapazes não têm filho.

Acho que sou uma mulher vencedora porque criei meus filhos. Depois de meu casamento com Genival tive mais qauatro filhos, que não são filhos dele: o Cássio, o Rodolfo, a Caroline e a Luana. A Luana é filha desse Barba que a Laura fala na entrevista, que considera como padrasto. Fui batalhando, tentando encontrar alguém para me ajudar a ser feliz, mas a sorte não bateu. Fui de um lado, de outro, arrumei um aqui, outro ali, não deu certo e acabei ficando sozinha. Mas os meus filhos estão aí, os meus filhos rapazes: o Felipe, o Rodolfo, o Cássio, tenho uma mocinha com 12 anos, que é a Luana e agora essa minha pimenta, que é a Carol, e que espero que seja a última, com fé em Jesus.

Estou lutando, no momento estou desempregada, procurando, mas se Deus quiser vou encontrar logo um emprego porque preciso trabalhar, preciso ajudar meus filhos. Minhas filhas estão casando, estão vindo os meus netos e preciso mostrar para eles que sou uma avó guerreira, e quero que minhas netas sejam como eu: trabalhadeiras, lutadoras, de uma moda sem prejudicar ninguém, honestas, decentes, pobres, mas dignas porque acho que o mais importante é você ter dignidade. Não importa o que você é, o importante é que você seja honesto, que você possa entrar e sair em qualquer lugar, sem deixar mancha em canto nenhum. A virtude é algo que ninguém tira, que vem de berço, vem de longe. Digo para eles todos os dias: "Quero que vocês sejam exatamente isso, não precisam ser mais, porque se você quiser ser mais do que isso não vai conseguir, vai atropelar lá na frente. Vocês têm que ser como são e do jeito que eu ensinar para vocês está bom, porque até aqui para mim foi ótimo”. Se eu passar daqui para lá acho que não vou conseguir. Até aqui foi ótimo, foi bom, foi maravilhoso!

É uma pena que perdi a minha mãe, vai fazer três anos. Mas é essa a vida, isso faz parte. Há três anos foi ela, depois vai ser outro, daqui a 10, 15 anos não sei, vai ser eu, vai ser nós, mas uma coisa eu digo: quando eu faltar nessa terra quero que meus filhos, meus netos e até a minha quarta geração... Não quero que falem: “minha avó, minha mãe, foi uma pessoa inútil”. Não, quero que eles falem: "Ela morreu, mas morreu lutando, morreu falando" Eu falo muito e quero que eles passem para os filhos deles e para os netos deles aquilo que ensino. E vão passar porque Jesus é bom.

Ensino também a outra parte do Evangelho. Costumo dizer para eles: “A primeira coisa que você tem que fazer quando abrir os olhos é se agarrar em Deus, porque ele é o nosso ontem, o nosso hoje e será para sempre. Sem Deus nada podemos fazer”. Tudo o que somos, tudo o que temos, tudo o que vivenciamos é permissão de Deus. Se hoje estou dando essa entrevista é porque tive permissão de Deus. Temos que agradecer a ele por todas as lutas, e já fazia isso 
mesmo quando era pequena, pobrezinha, que não tinha sequer um chinelo para por nos pés. Muitas vezes, quando meu pai podia comprar um chinelinho assim, de dedo, para a gente calçar, ficávamos tão orgulhosos que nem o calçávamos. Colocávamos nas mãos ou dentro de uma vasilha e íamos buscar água numa distância como daqui lá na avenida ou um pouco mais longe. A gente colocava dentro do balde para fazer inveja nas amiguinhas porque a gente tinha e elas não. Pisávamos no chão quente, mas não calçávamos os chinelo nos pés, para não sujar, para não estragar.

Hoje agradeço a Deus porque tenho meu guarda-roupa com roupas de vestir em casa, roupas de vestir na igreja, roupas de vestir no trabalho, roupas de sair. Naquela época a gente não tinha. Meus pais faziam roupa de saco de açúcar para a gente usar, fazia chinelo de couro de gado para nós calçarmos. As coisas melhoraram daquela época para cá e creio que daqui para frente é só vitória!

Falei para minha família que vou me casar de novo, que quero arranjar um companheiro para eu viver junto mais uns 20 anos! Não quero ficar sozinha porque eles vão todos casar, sair de casa, viver a vida deles. Acho que o Cássio já está namorando, está com uma cara de sapeca... Quero arrumar um companheiro, mas um companheiro de Deus, evangélico, porque aí ele não vai me trazer muitos problemas, como os que tive no passado. Se não for dessa forma também não quero. Estou bem abençoada sozinha, mas se vier um servo do senhor para me ajudar a aconselhar meus filhos quando eles precisarem, vou aceitar.

Sou da Igreja Deus é amor. Na igreja Deus é amor sou nova, tenho apenas cinco anos de caminhada, mas já faz dez anos que sou evangélica. Saí da igreja em que congregava, passei uns dois ou três meses sem congregação nenhuma, depois o Espírito Santo de Deus me guiou à igreja Deus é Amor. Dia 30 de Maio vai fazer cinco anos que me batizei e para a glória de Deus hoje sou pregadora da sua palavra. Não para a minha honra, mas para a honra do nosso Deus, e falo muito porque crente fala demais!

Costumo falar, falar, tenho essa coisa de falar e agradeço a Deus porque ele nos deu a boca, a língua para nós falarmos, se fosse para ficar mudo ele não tinha dado, não é verdade? Então, minha filha, essa é uma parte da minha história, uma história de luta, de vitórias e muita saudade da minha terra e do meu povo.

Quando morava no Piauí era muito bom! A gente buscava lenha no mato, a gente ia para a roça trabalhar, trabalhava na enxada e quando era uma base de umas cinco horas da tarde, cinco e pouco, meu pai falava: “Meus filhos, vão buscar lenha!” Aí agente ia paro o mato cortar lenha, eu já passava a mão no machado, porque era boa de machado, até hoje sou, porque o profissional não esquece sua profissão. A gente ia para o mato, trazia aquelas lenhas bonitas, colocava no terreiro. Terreiro aqui é coisa de macumba, mas lá, terreiro é a frente da casa, onde 
nós varríamos com aquelas vassouras de malva que eram uma bênção. Quando era noite o meu pai acendia aquela fogueira e se era época de inverno a gente ia assar milho, assar batata doce, se não era época de inverno o meu pai sentava ali com nós todos e começava a contar história. Mas era mentiroso, contava cada história! Eram lindas as histórias do meu pai!

Uma vez ele falou uma história que me deixou amedrontada, essa é uma história verdadeira, não é conto da carochinha, não. Foi um fato que aconteceu quando ele era rapaz, tinha entre os seus 15 e 18 anos. Ele não foi criado com o pai dele, o nosso avô a gente não chegou a conhecer. Foi criado em uma fazenda chamada Massapé, lá no interiorzão do Piauí, nem sei para onde fica.

Papai trabalhava de vaqueiro e para sair de uma fazenda para outra era muito longe, dois, três dias e viajem. Ele disse que ia com os vaqueiros levando um gado e que tinha um lugar em uma baixada... Quando estavam bem lá no alto, lá em cima, altas horas da noite, começaram a sentir sede. A água que eles lavavam naquelas cabacinhas tinha acabado. Meu pai falou: “E agora? Como é que a gente vai fazer? Não tem água!” Aí o colega dele disse: “Olha, Raimundo, lá em frente tem uma casa, vamos encostar o gado, ver se o companheiro lá tem curral para gente colocar o gado e pousar por lá até o dia amanhecer. Quando o dia amanhecer nós segue em frente com o gado".

De lá do alto eles viam uma luz naquela casa, como a chama de uma vela. Foram descendo para lá, mas quando chegaram bem perto da casa aquela velinha que estava lá se apagou. Ele disse que viu claramente aquela velinha lá fora, mas quando começaram a aboiar, ela se apagou. Chegando em frente da casa o cavalo começou a cismar, cismar, bater com as patas. Não queria encostar. Meu pai cravou a espora nele e conseguiu chegar, amedrontado. O gado ficou lá todo acampado, chamaram, mas ninguém saiu, ele disse que olhou para dentro: casa grande, aquelas casarões do Norte, e lá estava a velinha bem lá no fundo. Ele disse: “Deve ter um senhor bem velhinho aqui que não escuta direito”. Desceu do cavalo e entrou com farolete na mão e quando viu, não tinha ninguém na casa. "E agora?” Ele disse que os cabelos dele se arrepiaram, o gado se exaltou e ele gritou para o companheiro dele: "Companheiro, aqui não tem ninguém não!” E o companheiro respondeu: “Então volta, Raimundo”. Mas ele: “Não, já que estou aqui vou procurar um pote para a gente beber água”. Com aquele faroletezinho ele procurou, procurou, procurou, foi lá, foi cá, quando chegou à cozinha encontrou um pote, mas estava coberto de teias de aranha, tão velho que estava.

Naquela casa não morava ninguém há 20 anos! Não tinha ninguém, os donos da casa tinham morrido, a proprietária daquela fazenda era uma moça, filha única e devido os pais terem morrido ela foi embora e abandonou aquilo tudo. Meu pai falou: “Danou-se!” Tiveram que ficar 
lá fora e quando foi umas quatro horas da manhã levantaram com o gado e foram embora. Ainda tiveram até a tarde para chegar nessa fazenda onde iam entregar o gado.

Quando ele chegou lá na fazenda perguntou para o moço sobre aquela fazenda assim, em tal lugar, que não tinha ninguém, que parece que está abandonada. Contou que tinha uma vela lá, mas sumiu, e os peões disseram: “Olha, Raimundo, aquela baixada lá está amedrontada! Todos que passam por ali sempre vêem alguma coisa, só que vai, chama, não tem ninguém. Aquela fazenda foi abandonada há 20 anos quando fulano e fulana morreram. A filha deles, filha única abandonou, foi embora e naquilo ali não tem ninguém não”.

Na volta meu pai passou pela casa, estava tudo caído, tudo abandonado. Ele falou que era uma alma. Eles costumam falar que era uma alma, a alma dos velhos que estava ali, mas eu sei lá... Ele contava muitas histórias, é que hoje não me lembro mais, ele contava muita história bonita para nós, era um bom contador de histórias, até hoje ele senta com os meus filhos e começa a matar a gente de rir.

Hoje ele está com 80 e poucos anos. Quando estava muito quente, muito calor, a gente passava até altas horas no terreiro. A lua bonita, linda, linda, no céu, aí não precisava fazer fogueira. Nós colocávamos a esteira lá fora e ficávamos deitados escutando ele contar as mentiras dele. Minha mãe não contava história, gostava mais de ficar ouvindo e rir. A época mais feliz da minha vida foi aquela! Com toda a simplicidade, com as dificuldades, com tudo! A gente tinha prazer de levantar de manhã e ir para a roça. Na época de inverno era melancia, caju, manga, cana, abóbora, milho verde, feijão verde, imbu, cajá. Cajá é uma fruta aqui que o povo não conhece. Dá um suco muito bom!

Felizmente meus meninos ficaram um tempo lá no Piauí e conheceram um pouco dessas coisas, dessas frutas, dessas histórias. Quando eu morava no norte a época que a gente mais gostava era a das safras, porque tinha tudo o que a gente queria. Não era uma fruta de São Paulo, não era uma coisa de cidade grande, mas era o divertimento que nós tínhamos. Eu amo o meu norte, amo o meu nordeste, é muito seco, deserto, mas não pretendo morrer em São Paulo, pretendo voltar para minha cidade. Comprei uma propriedade lá, fiz uma casa já me preparando porque no dia em que eu não tiver mais condições de viver aqui volto para lá, vou plantar minha macaxeira, meu milho, meu feijão, criar minhas galinhas, vender bastante ovo. Passei cinco meses no norte e já tinha 35 cabeças de galinhas, deixei para meus meninos, quando eles ficaram lá, eles comeram tudo.

Acredito que com Deus na frente vou voltar para o meu norte, porque nunca esqueci do meu passado, da minha vivência. Tudo aquilo foi uma experiência para eu aprender a sobreviver. Se na cidade grande não der eu volto para a minha cidade, sei me movimentar, sei sobreviver e também ensinei isso a meus filhos. Ensinei-os a comer mandioca, cuscuz, farofa de ovo porque o 
dia que não tiver o pão eles sabem ir lá, pegar uns quatro, cinco ovos, estrelar numa frigideira, fazer uma farofa, tomar o seu café e ficar sossegado, porque foi assim que minha mãe fazia conosco, quando não tinha alguma outra coisa melhor. Lá no interior nunca teve pão com manteiga, nós fomos criados comendo beiju, que é essa tapioquinha que vendem aqui, com leite condensado, com coquinho. Na minha cidade não tinha com leite condensado não, era beiju mesmo, fazia desmancha de mandioca, tapioca, porque quando era rança de mandioca passava muita gente trabalhando, raspando mandioca, aquele motor roncando, coitado daqueles homens, sofriam, mas era um divertimento para eles, um trabalho muito bacana, e ali a gente comia beiju, batata doce, mandioca, abóbora, farofa, carne de porco. Era aquela bênção e vivíamos bem, não tinha enfermidade, não tinha doença, não tinha essa fraqueza que nós temos aqui na cidade grande. Lá o leite é puro, tirado do peito da vaca, aqui, o leite que nós bebemos é uma água, fora as químicas, a contaminação que tem...

Lá eu tiro leite purinho da cabra, da vaca, você vê que o gosto é diferente. Foi com isso que fui criado e por isso tenho disposição. Até hoje tenho uma disposição boa e não me troco por qualquer mocinha de 19 aninhos, não! Não tenho medo de enfrentar trabalho porque fui criada com coisas originais, coisas purificadas. Hoje, eles tomam café da manhã: pão, manteiga, leitinho, daqui a pouco falam: “Ai mãe, to morrendo de fome!”. A gente pegava na enxada e se fosse preciso virar virava o dia inteiro trabalhando na enxada, porque comíamos coisas originais, coisas boas.

Muitas vezes comi batata crua. A gente estava carpindo e tinha tanta batata que elas pulavam, vinham para cima da terra, a gente só fazia tirar a casquinha e comia. Depois vim saber que batatinha crua é boa para o estômago, para gastrite. O próprio Deus encaminha você na coisa certa, eu não sabia que aquele alimento servia como remédio. Existem coisas maravilhosas, experiências que a gente jamais esquece. Meus filhos viveram pouco tempo lá no norte, mas já deu para eles entenderem porque quero voltar para lá, voltar para minha casa e aqueles que quiserem me acompanhar serão bem recebidos.

Aqui em São Paulo sofri demais. Quando me separei do meu primeiro marido, que tinha a Luciana, a Laura e o Filipe pequenos foi muito duro, batalhava, batalhava, batalhava e não conseguia ter uma situação econômica tranqüila. O pai deles nunca me ajudou em nada, aí tive que levá-los para o Piaú, deixá-los com minha mãe, mas ela, coitada, foi mordida por uma cascavel há uns 30 anos. Ela estava buscando arroz na roça, colhendo os cachos de arroz e pisou em cima, então a serpente a picou. A partir desse momento não teve mais saúde. Não morreu, mas ficou doente, começou a perder a visão, começou a ter problema de batida no coração, as pernas começaram a manchar. Minha mãe não é escura que nem eu não, ela é bem clarinha, ficavam aquelas manchas, aquelas patacas correndo água do corpo dela, contaminou o corpo 
inteiro, inclusive o sangue, porque deu diabetes, e devido isso, ela tampouco pode me ajudar. Deixei os meninos com ela, mas ela não pode ficar, adoecia direto e meu pai tinha que levá-la para a capital, para ficar internada. Essa foi uma das partes piores da minha história: minha mãe enferma e eu sem ter com quem contar. Foi uma hora que não tive pai, não tive mãe, não tive irmão, não tive família, não tive nada. Fiquei assim: um ser humano em cima da terra que está ali por estar. Parece que todos se cegaram, ninguém conseguia enxergar e fiquei com minhas crianças para cuidar, desempregada.

Arrumei um companheiro, o companheiro foi embora com outra mulher, uma vizinha minha. Fiquei sozinha com meus filhos e nosso barraco caiu em cima de nós, de madrugada, no meio da tempestade. Olhei para um lado, olhei para o outro, meus filhos todos pequenininhos, só a Luciana que era maiorzinha, coitadinha. O Filipe não estava comigo, estava com meu pai lá no Piauí. Ainda bem porque só com eles três foi mais fácil de alguém me acolher, mas eu sofri muito! Fiquei morando com eles na casa de uma amiga.

Perdi tudo, tudo, tudo. Só fiquei com meus filhos porque Deus foi misericordioso: estava acordada por causa da chuva, mas se estivesse dormindo a gente tinha morrido. A Laura tinha na época uns cinco ou seis anos. E naquela época eu bebia, se tivesse bebido alguma coisa naquele dia... Minha bebida era diferente da dos outros, os outros bebem qualquer hora, eu, como já era escaldada, já tinha um compromisso na minha vida, só bebia final de semana quando estava com eles dentro de casa, segunda, terça, quarta, quinta, sexta e sábado eu trabalhava. Quando vinha do serviço, no sábado, passava em um bar de um amigo meu, chamado Lucas e falava: "Lucas, prepara para mim uma garrafa de rabo de galo”. Rabo de galo é Contine com Caninha 51.

Chegava em casa ia cuidar das crianças, limpar casa e levar roupa, ficava lavando roupa e tomando minha bebida. Isso, quando não acontecia no sábado acontecia no domingo. Ficava meio zonza da bebida, deitava e dormia tranqüila, já tinha dado almoço para eles, nunca os deixei abandonados. Sempre tive a responsabilidade de fazer tudo dentro de casa "a pronto e à hora” para que não chegasse ao ponto de chegar alguém e falar: "Olha, ela bebeu e deixou as crianças à toa”. Nunca! Aí eu dormia e eles: ‘Mãe, acorda que já é de noite”. Acordava, muitas vezes pensava que já era o outro dia, que tinha perdido a hora, mas não tinha não. Eles queriam comer e me acordavam. Aí na segunda-feira trabalho novamente.

Sei que eu cheguei a morar na casa de uma amiga minha, para você ver a situação... Tem coisas na vida das pessoas, que só Jesus mesmo... Essa minha amiga me acolheu depois do desabamento porque eu não tinha para onde ir, não tinha condições de alugar uma casa, não tinha experiência para alugar uma casa porque nunca tinha morado de aluguel, aí ela me acolheu, mas ô meu Deus, todo dia me mandava embora. E eu dizia: "Mas Maria, para onde eu vou com essas 
crianças? Você não tem juízo não? Eu to procurando um lugar!” Até que graças a Deus consegui vir morar para cá, no Menininha.

Estou aqui há 16 anos. Cheguei mediante um Movimento Social que tinha como uma de suas líderes Dona Tereza. Ela havia conseguido vários terrenos e me ofereceu um. Como já tinha uma amiga que morava aqui, a Vera, e que antes de vir morar aqui me trouxe para conhecer o Jardim Ângela, acabei ficando. Ela me apresentou para Alceu Viana, que cuidava do Movimento, não me lembro o nome, mas sei que esse movimento tinha um nome. O senhor Alceu Viana falou: “Não, pode deixar ela aqui que a gente vai ajeitar”. É o que Laura falou que eu paguei um homem para fazer o barraco... Ele falou: “tem madeira? Tem material?” eu falei “tem!”. Um amigo meu lá do Rosana me trouxe uma caminhonete cheia de material, porque do barraco antigo não deu para aproveitar nada. Trouxeram telha, folha de madeirite, um monte de coisas, seu Viana entrou com providência, chamou mais um moço e já levantou o barraco, um senhor barraco, bonito o meu barracão!

Graças a Deus entrei nesse barraco e passado uns tempos conheci o pai da Luana. Ele me ajudou a construir minha casa, construiu três cômodos de casa para mim. Comprei o material e ele começou a construir, é pedreiro e foi construindo.

Hoje pago aluguel, fui obrigada a vender a casa, porque tive um problema, mas como falei comprei um lote lá no Piauí e comecei a construir uma outra casa, com o dinheiro dessa que vendi. Não fiquei desabrigada, graças a Deus. A gente paga aluguel, o meu filho trabalha, a gente trabalha, pago aluguel, mas tenho a certeza de que a qualquer momento, qualquer dia que eu disser: "Quero ir embora para o norte”, tenho um lugar para morar, tenho um campo para cuidar, para eu trabalhar. Meu filho falou: "Mãe, porque a senhora não comprou uma casa aqui? Lá no norte é ruim, é seco, é isso, é aquilo”, mas eu não pretendo ficar aqui. Pretendo ir para a minha cidade, curtir minha velhice lá. Na casa dos meus pais não dá mais para eu ficar, tenho que ter o meu cantinho, então foi por isso que fui para lá, comprei o terreno e construí a minha casinha. Comprei a minha propriedade, para o dia que eu precisar, que não der mais certo em São Paulo, ter um lugar para ficar.

Não é minha vontade ver a Laura nesta ocupação, mas não posso proibi-la. Ela tem uma parte que puxou para mim, uma parte de teimosia. Sou teimosa, se quero uma coisa vou em frente, vou até o fim, e ela herdou isso de mim. Já passei por situação semelhante tempos atrás, já lutei muito para ter casa, mas hoje estou cansada, não tenho mais essa disposição para fazer o que ela está fazendo. Ela lutou muito, eles lutaram muito, passaram muito atropelo, muita fome nessas reuniões, chuva, frio. Laura ficou gripada, ficou doente e somado a isso, passou por muita humilhação, muita humilhação! Muitos apoiaram, mas muitos humilharam. É triste ver os filhos da gente acampados em barracos de lona, ver que chegamos a essa situação! 
Meu Deus, para gente ter uma moradia não precisava tanta coisa! Somos seres humanos, cada ser humano merece ter um teto para morar O que acho errado no nosso governador, é eles permitirem que tenha pessoas vivendo assim no nosso país e eles ainda são capazes de nos negar um lugar para viver. Ninguém aqui está querendo luxo, mansão, estão querendo um cantinho para morar porque não têm condições de pagar um aluguel, aluguel está difícil! Eu pago R\$: 220,00 de aluguel e só falto morrer, tem horas que falta o leite da Caroline, falta a fralda, falta o pão de cada dia dentro de casa, mas tenho que pagar o aluguel! O que estamos atrás é de uma moradia, não é de luxo, de mansão, de apartamento chique. Queremos simplesmente um lugar para viver. É necessário, todo ser humano precisa de uma moradia. Eu falei para Laura que não queria que ela estivesse aqui não, se dependesse de mim ela não estaria aqui, mas é o que eu te falei: ela é teimosa e é lutadora. E pessoas assim são vencedoras. Se eu não tivesse sido teimosa e lutadora como ela talvez meus filhos não estivessem comigo, teriam ido para adoção, para colégio interno, teriam sido criados sem pai e sem mãe, jogados por aí.

Disse a mim mesma: "Eu posso dormir sem comer...” Quantas vezes dormi sem comer para que não faltasse para eles amanhã? Vendi a minha roupa do corpo para dar comida para eles, chegou uma posição na minha vida que eu não tinha trabalho e não tinha o que dar para eles comerem, peguei uns dois blazeres importados, que eu tinha ganhado das minhas patroas - elas gostavam muito de mim e me davam roupas boas - e vendi. Abri o meu guarda-roupa e falei: “Senhor, não vai ter outro jeito, não vou deixar os meus filhos com fome”, peguei dois blazeres muito bonitos, saí e não tive vergonha de oferecer para minhas amigas: "to vendendo porque não tenho gás em casa e porque meus filhos estão sem comida”. E elas compraram? Não, elas pegaram o blazer, guardaram e me deram o dinheiro. Quando arrumei um emprego elas falaram: “Agora você me dê meu dinheiro e vá buscar seu blazer, que eu não usei, está lá guardado”. Ainda tenho um deles.

Ser vencedor é isso: é lutar, porque sem luta não tem vitória! E no final é que a gente consegue vitória, a gente luta, luta, pensa que está acabando, mas não, está vindo mais luta. Um soldado entra na guerra para batalhar e não entra na intenção de perder, não é verdade? Estamos aqui para lutar. Laura quer lutar no MTST, deixe-a lutar e vamos ver o que é que vai dar, se de repente ela chegar no fim e for vencedora vai cantar a bandeira da vitória e todos vamos ficar muito felizes. 


\section{Luana}

“Fica chato viver longe de uma pessoa que você gosta tanto”.

Desde pequena tenho vontade de ter mais tempo para poder estudar, porque gosto muito de estudar e queria me formar professora. Meu sonho é aprender a tocar violão. Sempre observo as pessoas tocando, até comecei a estudar, estavam me ensinando a tocar guitarra, só que com tantos afazeres não deu para eu aprender. Nessa época também tive que ir para o Norte. Se não me engano isso foi em 2003.

No Norte aprendi várias coisas legais, estudei muito porque lá é um lugar em que a gente é livre. Todo dia você pode fazer alguma coisa no meio da rua, pode passear, pode ir a todos os lugares que quiser, porque é tranqüilo, é um lugar que não tem bagunça, não tem essas coisas como tem aqui em São Paulo, e é muito legal. A professora trata a gente muito bem e lá tem umas coisas que a gente não aprendeu aqui. Lá tem uns tempos em que a gente vai matar passarinho, matar essas coisas, esses bichinhos que andam no ar... Aqui em São Paulo, não aprendemos muitas coisas como aprendemos lá. Foram dois anos que ficamos lá, mas nesse tempo aprendemos muita coisa, foi muito legal! Então meu sonho é aprender a tocar guitarra e voltar para o norte.

No Piauí morávamos no sítio do meu avô, um sitiozinho que está lá até hoje dando os frutos. Minha mãe comprou um terreno perto desse sítio e quem está cuidando é minha irmã Luciana, que mora lá. Ela praticamente nos criou, porque minha mãe não tinha tempo de cuidar de nós, trabalhava dia e noite. Era a Luciana quem cuidava da gente, dava banho, mandava para a escola. Era ela que convivia com a gente o dia inteiro, o tempo inteiro, e foi ela que me ensinou a ler, a escrever. Agora ela tem 24 anos.

Tenho muita vontade de voltar para o Piauí, só que não agora, porque tenho meu pai aqui e fica chato viver longe de uma pessoa que você gosta tanto. O nome do meu pai é Jasam da Silva Santos, mais conhecido como Barba, e meu nome é Luana Silva Santos. Se eu for para o norte vou estar com a minha mãe, mas não vou poder ter aquela coisa que tenho com o meu pai aqui. Meu pai não quer ir, ele tem a vida dele, minha mãe tem a vida dela, são separados, mas cada um segue seu caminho sem aquele negócio de um ficar implicando com o outro.

Lá no norte, quando a gente ia para a escola bagunçava muito! Eu gostava muito de bagunçar, a única coisa que não gostava de fazer era Educação Física, não gosto até hoje, e assim fomos convivendo.

As aulas que eu mais prestava atenção eram as de Matemática e História, mas éramos pequenos, não conseguíamos prestar atenção direito, ficávamos brincando, tinha vezes que tinha até briga dentro da sala, um ficava chutando o outro. Estudei a primeira série aqui, a segunda e a 
terceira lá. Eu era pequena. Aí, como lá no Norte é um professor só por turma, que ensina Português, Matemática, História, Ciências... Só não Inglês, porque Inglês é depois da quinta série, e esse professor era meu cunhado, era muita bagunça! Ele é um professor muito bom porque ensina o que a gente deve fazer e o que a gente não deve fazer. Os professores lá do Piaú são muito mais... Parece que têm muito mais cabeça do que os daqui, porque aprenderam do jeito deles e ensinam para nós de um jeito diferente, mais paciente, mais prático.

O Piauí, na minha opinião, é um lugar muito bom. Se eu fosse crescer aqui, passar a minha vida toda aqui... Não tenho vontade!

O pior defeito daqui é a matança e as confusões, roubo, briga... Não é a gente que faz, mas pode acontecer com qualquer um de nós, a gente é vítima. Pode acontecer com qualquer um que more em São Paulo. Não é que nos outros lugares não tenha morte, mas é difícil você ver, não acontece tanto como aqui.

São Paulo é um lugar terrível! Tenho medo, tenho muito medo e não saio de casa não, não vou à rua, não gosto de ficar na rua porque tenho que evitar os perigos para mim e para os outros também. Evitando para mim, posso evitar para alguma colega minha, porque se eu estiver na rua ela vai querer ficar comigo, mas não estando, ela também não vai estar.

O único ponto positivo de São Paulo, o único lugar bom que conheci até hoje é uma chácara que meu pai tem em Itapecerica da Serra. Cinco terrenos, um maior que o outro. Gostei de lá porque é um lugar fresco, que não tem muito movimento igual aqui e lá a gente pode conversar mais, sentir uns aos outros sem implicância. Tem árvore, tem frutas, tem cachoeira. Conheci esse lugar através do meu pai, ele mora lá. Como é distante daqui tem vezes que fico sem vê-lo, mas é muito legal lá, tem cachoeira, tem todas as frutas que dá lá no norte e que aqui é muito difícil de encontrar: cana-de-açúcar, caju, umbu, cajá. Você pode ir a uma banca de frutas, procurar umbu que muitas vezes os feirantes nem sabem o que é, e se tiver, é por um dia, dois dias e só.

Todas essas frutas existem no sítio do meu pai e vou lá com freqüência: uma vez por semana, às vezes duas vezes por mês, três, dependendo das folgas dele, porque não é todo dia que está em casa. Faz um serviço aqui, um serviço ali, só esse mês está com três serviços para fazer, ele trabalha de pedreiro. Está terminando um serviço, já vai entrar em outro, e depois no outro, e assim vai, não tem previdência para ele estar em casa. É muito difícil encontrá-lo em num sábado ou domingo.

Tenho três irmãos por parte de pai: o Gilmar, a Cleonice e a Cleide. Eles são muito legais comigo e nos relacionamos muito bem. Sou a caçula. Vai fazer uns três meses que não os vejo, mas quando meu pai vai lá é um mandando beijo para mim, é um mandando carta para 
mim, entendeu? A gente convive assim: eu aqui, eles lá, e graças a Deus nunca tivemos problema.

Por parte de mãe somos sete irmãos, e por parte de pai somos quatro. É tudo em paz, tanto lá quanto aqui. Tem vezes que de lá do Piauí a Luciana liga chorando, a gente fica preocupado, mas daqui a pouco já está tudo bem e assim vamos convivendo.

Tenho muito desejo de voltar para o Piauí porque lá é um lugar de muita paz, de muito amor. Coisa que você não aprende lá você aprende aqui, só que é muito mais difícil você aprender aqui. Lá fiquei uns dias sem estudar e quando retornei para cá tive que voltar para a mesma série. Nossa, lá a gente fazia muita bagunça na sala de aula, mas não me sinto envergonhada de contar isso, porque era criança e acho que cada um deve ter a sua infância enquanto é pequeno.

As pessoas gostam de brincar, de fazer piada, de inventar uma mentirinha. Dia da mentira lá é muito legal, muito legal mesmo! A gente bagunçava muito na sala, mas a coisa que não rolava lá era palavrão, porque a gente foi criado sem essa coisa de palavrão. E era uma bagunça depois que acabava a lição. Eu gosto muito de lá, porque a gente ia para o sítio, brincava de matar os bichos no alto, com baladeira, nós começávamos a brincar, brincávamos com os porcos, porque lá no meio do mato tem muito porco do mato, íamos tomar banho em um tanque que tinha lá perto, era muito bom! A gente cutucava os sapos, ficava brincando com eles, dava medo, mas era divertido e com fé em Deus vou voltar para lá.

Aqui em São Paulo do que mais brinquei foi de pular corda e andar de bicicleta, inclusive, quando fui para o Norte não sabia andar de bicicleta, foi aqui que vim aprender, e agora estou aprendendo a jogar vôlei e futebol. Também aprendi muitas coisas aqui.

Nunca gostei de brincar com boneca, nunca gostei de brincar de casinha com as minhas colegas. Gosto de brincadeiras mais agitadas, que desenvolvem nossas habilidades, mas também gosto de ursinho de pelúcia, de dormir com ursinho. Hoje brinco mais de vôlei, e sempre no meu quintal, não brinco na rua. Às vezes pulo corda. Agora tenho minha irmãzinha, arrumei mais uma companheira, a gente brinca, mas dessas outras brincadeiras eu não gosto mais de brincar. Não tenho boneca, agora minha irmã tem um monte. Tem ursinhos... A Carol adora brincar de boneca, já eu ...Tenho essa coisa comigo de gostar de atividades mais agitadas, então escondeesconde, pega-pega são coisas que já gosto, porque desenvolvem. Quando você está correndo parece que você cresce, estica, se desenvolve...

Moro ao lado da escola, é divertido. Quando quero brincar na escola é fácil e daqui da janela do quarto vejo a quadra poli esportiva. A escola é um lugar seguro para brincar, é melhor que ficar na rua. Morar perto da escola também não permite desculpas para chegar atrasada na aula, não dá para dizer: “ah, cheguei atrasada, o ônibus...” São cinco passos. 
Gosto muito de ler, e Português é uma coisa assim: que exige leitura, compreensão, por isso acho que é a primeira matéria que você tem que aprender. É a língua que a gente aprende a falar, e precisa também aprender a escrever, aí depois vem vindo as outras matérias. Agora Matemática é uma coisa muito boa, que gosto muito, porque se você fizer uma conta, mesmo que você quebre a cabeça, consegue entender e resolver aquela conta, é muito bom. Eu acho bom você levar um “Certo” no caderno, ter seu caderno em ordem. Se você levar um “certo” tem a confiança que aprendeu, que está no caminho correto e não vai errar mais.

História também é ler, é decifrar as palavras. Gosto muito de História. Como estou na quinta série não usamos mais livro, estudamos pelos textos que o professor passa na lousa. Acho bom copiar da louca porque se você ficar em dúvida quanto à grafia de uma palavra, você olha, conserta. No momento estamos estudando coisas contemporâneas, coisas do Brasil. Tem outra matéria que aprecio muito, que é Inglês. Tem umas palavras que você aprende ao falar e é muito legal: good morning, umas palavras que quando você está na primeira série você fala, mas não sabe o significado e agora, na quinta série, estamos aprendendo. Inglês é muito legal, agora das outras matérias não gosto muito. Queria ser professora de Inglês, esta é a única matéria que tenho vontade de ser professora mesmo. Às vezes ouço música em Inglês, porque minhas vizinhas ligam o aparelho de som em volume bem alto, mas ainda não consigo decifrar aquelas palavras, mas, gosto do som, da sonoridade da língua.

Gosto muito de música, estava indo para os ensaios na igreja. Estava aprendendo a cantar e tocar. Minha mãe é crente. Tinha uns tocadores que iam para lá ensaiar com a gente e estavam nos ensinando a tocar violão, ensinando como se pega na palheta, como se vai controlando as cordas, só que depois teve um reboliço na igreja e ficou muito difícil de a gente aprender, mas a minha vontade, o sonho que eu tenho é aprender a tocar violão. Meu pai disse que vai me colocar na Informática, primeiro, que é preciso primeiro aprender Informática. Minha mãe está procurando uma aula de violão para me colocar.

Na verdade, não é de música que gosto, é de hino, de Góspel, como os da Cassiane. Os hinos de criança... Escuto bastante hino, mas é muito difícil eu cantar, gosto mais de ouvir, porque você desenvolve mais no escutar, aprende as palavras direitinho. Músicas do tipo: Rock, Samba e Funk eu não gosto, gostava, mas a partir do dia que entrei para a igreja não participo mais dessas coisas, esqueci.

Participo da igreja Deus é Amor, junto com minha mãe. Lá na igreja é muito legal e as coisas que você aprende são para sempre. Lá tem grupo de crianças, você canta, ora e pode fazer muitas coisas, participar de congresso, estudar a Bíblia. Também tem encontro de jovens, estudo bíblico para jovens. É muito bom estudar a Bíblia porque você está aprendendo a ler também, 
você lendo a Bíblia ou você lendo um livro você está aprendendo a mesma coisa, está aprendendo a decifrar as palavras e está adquirindo conhecimento.

Quando eu crescer também quero ser cantora, porque é assim, sempre quando vou à igreja, quando vou louvar ao Senhor, as irmãs falam que vou ser cantora, que é para eu cantar, que é para eu pregar, entendeu? Elas estão tendo essas revelações. Na igreja vou me desenvolvendo mais e mais, vou aprendendo mais coisas e das coisas que aprendi até hoje, viver segundo o evangelho é a mais importante.

Na minha religião não podemos usar calça, short, blusinha de alcinha. Se você tiver uma blusinha de alcinha você pode usar, mas com uma jaquetinha por cima, mas claro que o pastor e que Deus sabem, estão vendo. Você vê o mundo de hoje: muito desenvolvido, muita matança, muita briga, muito roubo e se a pessoa não quiser conviver com essas coisas a única opção que ela tem é procurar uma igreja, porque no mundo de hoje o que você vai aprender é matar, roubar e essas coisas.

Tenho doze anos e ser evangélica não é fácil, às vezes as pessoas não entendem... Pelo menos na minha sala de aula e na minha escola nunca ninguém me criticou, com exceção de uma professora, quando eu estava na quarta série. Ela levantou a mão para mim e me chamou de crentinha e aí nós discutimos, ela falou em voz alta com a minha mãe, mas foi a única pessoa que me criticou.

Estudo na escola estadual Pastor Cícero Canutto de Lima, aqui no bairro ÂngelaMeniniha, porque é o encontro dos dois. Estamos bem na fronteira, por isso essa região é conhecida como Jardim Ângela-Menininha.

Moro aqui desde que nasci. Fui para o nordeste quando tinha seis, sete anos, fiquei um tempo lá e depois retornei. Agora estou com 12 anos, faço aniversário dia 25 de setembro, no meio do ano, mas é muito bom. Adoro festa de aniversário, por causa dos doces, dos salgadinhos, mas em dias normais, como qualquer coisa, não sou enjoada para comida, a única coisa que não gosto mesmo é de salada de maionese e de um feijão que eles fazem com cenoura, batata, misturado com carne, mas não é uma feijoada. Quando eu vim para cá fui a um almoço de aniversário que tinha esse prato feito com feijão, mas não gostei. Essas são as duas únicas coisas que não gosto, o resto como de tudo: fruta, verdura, pizza. As coisas que mais gosto são pizza e uva.

Adoro a comida da minha mãe. Ela tem um jeito de cozinhar e um tempero que acho muito bom. Todas as coisas: feijão, arroz, carne, sai daquele jeito que só ela sabe fazer. Ela cozinha muito bem, já trabalhou em casa de família, em pensão que servia alimentos. Às vezes ajudo minha mãe a fazer o almoço e já sei fazer alguns pratos: arroz, feijão, carne. 
Para ir para a escola me levanto às seis horas da manhã, me arrumo. Tem vezes que saio de casa as seis e quarenta, tem vezes que saio seis e meia, para poder chegar um pouquinho antes. Espero o portão abrir, para não ter aquela coisa de falarem que cheguei atrasada. Entro as sete e saio meio dia e vinte. Tem vezes que saio mais cedo, às onze e trinta. Minha rotina em casa, depois que chego da aula é arrumar a casa, caso minha mãe ainda não o tenha feito, e cuidar da Carol. Quando estou doente ela não me deixa trabalhar, agora quando estou bem arrumo, cuido da minha irmã, dou as mamadeiras do jeitinho que ela gosta, porque criança gosta de mamar. Aí, depois de arrumar a casa tem vezes que pego um livro e vou ler ou terminar minha lição.

Como a gente está estudando com jornal, tem coisas que a gente não termina na sala, porque tem que devolver os jornais, e é mito difícil a gente lembrar para poder copiar. Estudar com jornal é bem interessante porque o que a gente não aprendeu no livro a gente está aprendendo agora. Tem várias páginas legais, com desenhos. Gosto muito de desenhar, tem muitas coisas legais. Na hora que a gente chega à escola já começam a distribuir os jornais, aí a gente faz a lição e quando é meio dia e dez, meio dia e quinze a gente entrega os jornais e fica esperando dar doze e vinte. Esses jornais são diferentes dos que saem nas bancas, são cinza e branco também, mas são fornecidos pela Secretaria de Educação, com informações especiais para a escola.

Meu horário de dormir é nove ou dez horas da noite. Durmo tarde e acorde cedo. Meu horário de acordar quando não tenho aula são oito horas, mas tem vezes que acordo às sete, porque minha irmã me acorda para tomar mamadeira, aí dou a mamadeira para ela, deito, viro para um lado, viro para o outro e não consigo mais dormir.

Falei que quando estou doente minha mãe não me deixa fazer nada. Tenho um problema de saúde, acho que não é bem uma doença... Sofro de epilepsia. Já ia fazer sete meses que eu não tinha crise, e aí tive essa semana, tive que ir para o hospital, porque estava sentindo muita dor de cabeça e nas costas. Quando tenho crise minhas vistas embaralham, não consigo ver direito, fico vendo duas pessoas, três pessoas, entendeu? É esse tipo de doença que tenho, mas acho que não é uma doença, é uma coisa produzida pelo meu próprio cérebro.

Dessa última vez que passei mal fiquei com muito medo, furaram os meus dois braços, ai é horrível, horrível, horrível! Você pensa que... Sei lá, dá uma pressão em você que você pensa que vai ficar ali, você começa a chorar, você vê os outros em depressão e começa a ficar em depressão também, começa a sentir uma forte dor de cabeça. O médico passou remédio, Gardenal, e estou tomando direitinho, de sete em sete horas. Eu estava brincando com crianças pequenas, com a Amanda e com a minha irmãzinha, aqui no quintal, aí subi para casa porque me 
senti mal, comecei a ter dor de cabeça, a ver tudo embaralhado. Minha mãe me mandou pegar uma coisa e eu não sabia como pegar, aí falei: “Mãe, to passando mal”.

Minha irmãzinha é muito fofa e sapeca, tem vezes que ela fica com raiva da minha mãe, bate nela e corre para o meu lado. Fala que foi a mãe que bateu nela, sendo que ela que bateu na minha mãe. Vem correndo para o meu lado, com medo de apanhar, mas é criança. Amo todos os meus irmãos e tenho muita admiração pela Laura e pelo Cássio, que estão lutando no Movimento dos trabalhadores sem-teto. Eles estão em busca de algo melhor para a vida deles, para a nossa família. Acho que aquele povo merece a vitória porque viver naquela situação não é fácil.

Todo mundo deveria ter sua casa. Já vai fazer vários dias que eles estão ali, acho que já deve ter até ano. Começou no Valo Velho, depois vieram para cá, é uma luta, eles estão ali para ter a casa deles, muitos têm família, precisam de um lugar para morar. Não é todo mundo que tem coragem de lutar como eles lutam, enfrentar o que enfrentam. Eu tenho, e se precisar, um dia também participarei de uma ocupação, porque vou querer ter minha família, ter minha casa, entendeu? Ali eu posso construir uma casa para minha mãe, posso ajudar minha mãe, ter o meu cantinho e ela o dela.

Meus irmãos que estão nessa luta por moradia sofrem muito, muito mesmo. Se for parar para contar o que eles já passaram, vão muitas páginas. Sempre vou lá ficar com eles, ajudar a Laura. Eles são determinados, estão ali para conseguir mesmo, e se não fosse assim não estariam para receber os apartamentos. Se eu fosse adulta iria para lá e se eu fosse uma pessoa que tivesse posse, igual esses prefeitos, eles já teriam conseguido, aqueles apartamentos já estariam prontos. 


\section{Cássio}

\section{“Se eu for para o Piauí não volto para São Paulo mais não!”}

Meu nome completo é Cássio Rodrigues da Silva e tenho dezoito anos. Nem parece, mas já tenho 18 anos... Nasci em São Paulo, no Hospital Piratininga, no Campo Limpo e fui criado perto da minha mãe, das minhas irmãs e dos meus irmãos. Nunca saí de perto deles.

Quando eu era criança o que mais gostava de fazer era soltar pipa. Esta sempre foi minha brincadeira preferida. Soltava muita pipa, quebrava laje alheia, telha dos outros, tudo por causa de pipa. Não só empinava pipa como saía correndo para apanhar as que eram cortadas, só faltava perder os dedos no meio da avenida...

Bola eu joguei pouco, mas teve um tempo em que desejei ser jogador de futebol, goleiro, porque gosto mais de defender. Brincava de muitas coisas na minha infância, só não brincava de boneca. Boneca era brinquedo para minhas irmãs.

Do tempo de escola, nossa, não gosto nem de falar! Este ano minha mãe me matriculou, estou matriculado, mas ainda não fui para a aula um só dia sequer. Não sou muito de ir para a escola não, mas quando ia aprontava demais, os professores faltavam morrer. E o professor Pedro então! Mandou que me levassem para a roça porque não me suportava mais. Chegaram a me amarrar em uma mesa porque não me agüentavam mais na escola. Foi muito engraçado! A única matéria que eu gostava era Educação Física, que consistia em ir para a quadra jogar bola.

Depois fui para o Piauí, e foi muito legal. Lá eu ficava matando pomba, rolinha, preá, era da hora! Tenho vontade de voltar para lá, hora que minha mãe decidir ir, vou atrás! Em 2003 eu e minha família nos mudamos para o Piauí, permanecemos por quase dois anos, depois voltamos para São Paulo. Em 2005 ou 2006 voltei para lá e passei mais uma temporada, cheguei esse ano e vou voltar para lá novamente. Lá eu morava com minha irmã mais velha, que é casada, mas sempre ia para o sítio dos meus avós. Minha diversão era ficar matando siri, naquele sol do caramba, mas era gostoso.

Quando cheguei aqui comecei a despelar, minha pele descascou toda. Agora se eu for para lá não volto para cá mais não! Gosto muito daquele lugar e gosto muito do meu avô, a gente sempre se deu muito bem. Sentávamos na frente de casa e ele começava a contar histórias, eu já até puxava um banco, escorava bem escorado para ficar lá assistindo as histórias do meu avô, sempre muito interessantes.

Também gostava de ir para a roça e de ir para a escola, a escola de lá é ótima, muito melhor do que as daqui. Você vê que é diferente, as salas de aula limpinhas, o pessoal não rabisca as paredes, os professores são mais pacientes, até o sotaque é diferente. Lá eu gostava de 
estudar. Minha mãe falou que a escola na qual eu estudava lá é a mesma em que ela estudou quando era criança, só que foi toda reformada. Lá as festas juninas eram muito boas, tinha muita Quadrilha e eu dancei muito. Lá eu estudava, ia para roça, cuidava dos bichos e também ia para a cidade fazer compras quando minha mãe mandava dinheiro. Era bom, nós íamos de moto, de carro, muitas vezes o carro quebrava no meio da ladeira, ainda bem que ficava parado, porque e se esse carro descesse? Lá eu dirigia, a cidade é calma e as pessoas são tranqüilas, não tem essa violência que tem aqui, não tem esse tanto de acidente. A gente podia soltar pipa sem medo, andar de moto, andar de carro, sair para passear sem medo, porque não tinha essas complicações daqui.

Agora estou morando na Vila Calú, nessa ocupação do MTST com minha irmã e meu cunhado, mas acho chato. Estou aqui há uma semana e conheço poucas pessoas. Que tenho amizade mesmo é só com a Lady, que já tinha sido minha vizinha lá no Jardim Menininha e com o Baiano, o namorado dela. Lady eu conheço desde minha infância.

Não posso dizer que gosto daqui, primeiro porque cheguei faz pouco tempo, segundo porque aqui a vida é muito difícil e tem todos os problemas que você pode imaginar. Ontem mesmo a Laura falou: "Vamos para o Piauí?”, e eu disse: "bora! Se eu começar a trabalhar vou juntar dinheiro e vamos para lá”.

Acho que vou conseguir um emprego de ajudante de pedreiro em uma firma, estou esperando o rapaz me chamar, ele vai me chamar aqui, por isso tenho que ficar morando nesta ocupação. Tenho experiência como ajudante de pedreiro porque trabalhava com o meu padrasto, que é um bom pedreiro. Trabalhei muito por aí, desde os dezesseis anos que trabalho, mas agora gostaria de ter um emprego fixo, com carteira registrada e é isso que estou tentando conseguir no momento. 


\section{Filipe}

\section{"A gente perde muita coisa quando vai crescendo"}

Moro nessa região do Jardim Ângela desde pequeno, acerca de uns 12 anos. Agora estou com 22. Quando minha família se mudou para o Piauí fui o que menos ficou lá, apenas dois meses. Percebi que lá não era um bom lugar para mim, para o meu futuro profissional, então falei comigo mesmo: “não, aqui não dá, vou arrumar outra coisa para fazer porque aqui está ruim”. Voltei e fui morar com meu padrasto. Até que gostei de lá, mas meu negócio é onde se ganha dinheiro, você tem que trabalhar e ganhar dinheiro. Não vou trabalhar na roça para ganhar R\$: 7,00 por dia, não estou morrendo. Vim porque para mim não tinha futuro ficar lá. Ficar fazendo o quê? Cortando mato?

De certa forma fui criado no Piaú, pois morei lá com meus avós até os meus sete anos de idade, mas até então era pequeno, não entendia muito bem as coisas. Desta segunda vez que fui para lá, com minha mãe e irmãos já percebia as coisas de modo diferente.

Antes de ir para o Nordeste eu trabalhava em casa de show, era técnico de palco, ofício que desenvolvo até hoje. Quando retornei continuei a fazer esse tipo de trabalho, mas em outra localidade. Um técnico de palco faz uma parte de cada coisa para que o show possa acontecer: iluminação, som, cenário, entre outras coisas. Fiz um monte de shows legais, mas o principal acho que foi o do Marcelo D2 com Jorge Aragão, no Anhembi. Aquele dia foi divertido! Não gosto de rap, prefiro rock, samba, pagode, sertanejo...

Meu celular deve ter umas 40 músicas de Bruno e Marrone. O estilo Marcelo D2 é diferente, é um rap com samba, mas de rap mesmo não gosto, é muita “maloqueragem”, coisa para doido, musiquinha sem letra, não gosto não! Agora um samba, um pagode, um sertanejo aprecio bastante. Não sou um colecionador de letras de músicas nem um grande entendido no assunto, mas escuto música freqüentemente no celular, às vezes o dia inteiro. Se estiver com o celular estou ouvindo música. Baixo do computador. O motivo pelo qual ouço música com freqüência é a bateria, adoro bateria e cheguei a tocar por uns tempos, aprendi algumas coisas, mas não sou músico. Ao ouvir música presto atenção no toque de bateria, a música para mim tanto faz, tanto fez, o que quero é saber se o baterista toca bem, se ele é rápido como os outros que vi tocar. Um dia vou fazer como eles.

Estava estudando, mas tive que trancar minha matrícula por causa do trabalho. Trabalho com teatro, viajando de um lado para outro, de um lado para outro, então como é que vou estudar? Não tem como. O estudo agora é como se fosse uma refeição fora do cardápio, mas um dia pretendo continuar. Parei no segundo ano do Ensino Médio, faltava o terceiro, depois eu podia fazer alguma faculdade, mas o tempo agora não permite. Outra coisa que aprecio além da 
bateria e do estudo é desenho, mas agora é como se eu estivesse fora de forma, acima do peso, porque não tenho tempo de exercitar, de me aperfeiçoar, mas quando tinha por volta de seis, sete anos eu desenhava muito, acho que o meu dia inteiro. Desenhava muitas coisas, inclusive as figurinhas do Looney Tunes e tinha uma pasta onde deixava os meus desenhos guardados, aí do nada parei, minha rotina de vida foi mudando, esqueci o desenho, deixei para lá.

Agora estou trabalhando com teatro, sou técnico de palco e maquinista. A diferença do teatro para o show é que você tem que montar o cenário, cuidar para que não aconteçam problemas durante o espetáculo, se tiver intervalo você tem que ir lá rápido, fazer as mudanças de cenário, tem que estar atento a tudo, saber onde pode quebrar e onde não pode quebrar. Se quebrar você sabe: "Pô, quebrou ali”, ai você vai lá rapidinho e troca. Fazemos peças para crianças, como musicais do Barney, da Moranguinho, Yu ghi yo. Essas peças são apresentadas em tudo quanto é canto: aqui, no Rio, em BH.

No final do ano passado tivemos um problema: um menino que trabalha comigo há nove anos brigou com um dos diretores então a gente fez uma separação. Por causa disso estou cuidando dos espetáculos aqui e no Rio de Janeiro, junto com um menino que iniciou nesse trabalho recentemente e esse meu colega está cuidando em Belo Horizonte, Goiás e Mato Grosso, com um outro garoto. Estamos apresentando duas peças. Minha rotina agora é daqui para o Rio, do Rio para cá. A confusão se deu entre ele e um diretor: discutiram, quase se agrediram e para ninguém ficar no "disse me disse” resolveram que um vai para um lado e o outro vai para o outro. Eu trabalhava com Barney, então tive que fazer essa ponte para ele vir para a Barney, porque o diretor de Barney a gente já conhece também há nove anos e é uma pessoa tranqüila. Tive que fazer essa troca porque se não ele ficaria desempregado, e isso não é coisa que se faça com alguém que trabalha contigo há nove anos.

Teatro é tranqüilo, mas não gosto de assistir, não tenho paciência. Assisti uma vez aqui no Credicard Hall ... Eu trampei no Peter Pan e no último dia a gente foi assistir à peça, rolou aquele vídeo no telão enorme e eu não tive paciência. Enquanto está rolando a peça não, é rapidão. Assisti ao Fantasma da Ópera também, pelo amor de Deus, não conseguia parar sentado, ia, voltava e aquilo parecia que nunca acabava. Não tenho paciência para sentar e ficar ali, assistindo, assistindo. Nem de televisão eu gosto, me incomoda esse tempo de ficar parado, mas acho que o pessoal gosta, porque lota, tem gente que vai três, quatro vezes assistir a mesma peça.

Ao contrário de show, que é um dia, em teatro a gente vira uma semana, duas semanas no mesmo lugar, aí muda para outro lugar e assim vai levando a vida, mas me atrapalha estudar. Quando tiver umas folguinhas quero fazer um curso de bateria, comprar uma bateria e treinar bastante, porque partiu para cordas pode esquecer, não tenho coordenação motora para tocar 
instrumento de cordas, sou totalmente esquisito para cavaquinho, guitarra, violão, agora pandeiro, essas coisas eu já entendo.

A Luana estava estudando violão na igreja, é talentosa, tem interesse, só não sei por que interromperam as aulas na igreja. Tem que arrumar algum curso, alguma coisa para ela fazer depois da escola, para não ficar aí desocupada. O Cássio não quer saber de nada, o negócio dele é fazer palhaçada. Já falei para ele que vou colocá-lo numa aula de teatro, porque ele é palhaço. Quando estávamos reunidos na casa do meu avô ele fazia todo mundo rir, é bem palhaço, mas não quer nada. O pai dele toca guitarra e violão há muito tempo, mas ele não quer nem saber. Sempre quis as coisas diferentes: eu desenhava, ele soltava pipa. Soltei pipa também quando tinha uns oito, nove anos, depois parei. Eu jogava uma bola, soltava pipa, andava de carrinho rolimã, essas tranqueiras todas que tinham quando a gente era pequena, mas não gostava muito, não era muito fã, meu negócio eram coisas mais sossegadas.

Não brincava muito porque o desenho não deixava. Minha parte na brincadeira era no máximo duas horas, eu passava o dia inteiro desenhando, pegava uma folha e começava a desenhar, esquecia do almoço, esquecia de tudo. Desenhava e pintava com lápis de cor, giz de cera, ficava bom, mais ou menos bom, era moleque...

Pena que não tenho esses desenhos guardados, nem sei o que fiz com ele. Quem tinha, que eu me lembro, era esse menino que pintava comigo. Há uns quatro, cinco anos atrás ele tinha uma pasta com desenhos e a gente ficava comparando: “Ah, você pintava melhor do que eu. Não, você pintava melhor!” Ele morreu e não sei o que fizeram com as coisas. Mas ele e eu passávamos o dia inteiro desenhando, perdíamos a noção do tempo. O tempo passava muito rápido. A gente fazia três, quatro desenhos completos por dia. Nossa rotina era desenhar, depois que chegávamos da escola. Depois parei, passou o tempo, cresci, vieram as responsabilidades. A gente perde muita coisa quando vai crescendo...

Agora o mundo é outro. Estou trabalhando, tenho que ficar estudando o cronograma de noite, trabalhar de dia, tenho que diminuir a porcentagem de erros, eu opero canhão também. Canhão é uma máquina de mais ou menos um metro e vinte, um metro e meio, mas um canhão antigo - os melhores canhões que têm são os mais antigos - devem ter por volta de dois metros. É aquela luz, aquela claridade que fica no cantor, no ator, em qualquer um que esteja em cima do palco, que seja a pessoa principal de uma banda, de uma peça. A gente tem que operar aquela luz de uns 20 metros de altura, às vezes pendurado. Com aquela luz você vai seguindo a pessoa. Hoje em dia, na linguagem moderna, se chama "seguidor”, mas é “operador de canhão” a pessoa que trabalha com essa máquina. Quando é uma peça que tem que operar canhão é mais complicado, às vezes tenho que operar um único canhão, fazer a troca para três atores, e isso exige toda uma coordenação de dedos e concentração total. Fico a noite inteira estudando aquilo, 
perco a noção do tempo e a vida vai passando, você está concentrado em uma coisa e o mundo está andando para frente.

Fiz esse trabalho muito tempo, fiz de tudo um pouco. Estava aprendendo também a mexer com som, trabalhei com isso uns quatro meses, nessa casa de show que eu trabalhava, onde briguei com o cara porque ele me chamou de filho da puta. Estava nervoso, perdi todos os direitos. Bati nele e fui embora, não voltei mais. Era lá que eu estava aprendendo, lá foi a porta para os outros serviços. Quando comecei a trabalhar lá era carregador - carregador é o cara que é pago para se foder, o mundo não está nem aí para ele, é como se fosse assim: Jesus virou as costas para aquele cara ali, ele tem que se foder, é problema dele. Com o tempo fui mudando de função, até que cheguei a técnico de palco, fiz minha primeira peça: Moranguinho, em 2001 e 2002, e depois disso nunca mais parei, tanto que minha atual patroa é a exata pessoa com quem fiz essa peça em 2001.

Naquela época eu tinha muito conceito, todo mundo gostava de mim. Eu era novinho, não tinha problema com ninguém. Apresentamos a peça da Moranguinho no Procópio Ferreira, e aí ela foi e falou para o meu patrão que ia me tirar de lá, ia me levar, juntamente com o Diego, para trabalhar com ela. Ele nos liberou, mas disse: "ó, qualquer coisa você vem aqui de noite, cobre alguma coisa para mim”. Eu ficava nesse vai-e-vem, não tinha tempo para nada. Ia de manhã para o teatro, saía do teatro, ia para lá a noite, lá mesmo dormia, nos camarins, saía de manhã, ia para o teatro, era a semana inteira assim: corrida. Foi rolando até que a gente foi brigando, brigando, acumulou, acumulou, teve uma hora que não deu, rolou umas agressõezinhas pequenas das duas partes e eu saí. O cara falou que ia me mandar embora, o Diego falou: “Se você vai também vou!”, “Então vamos os dois juntos” e aí passou um mês e 18 dias e a gente já estava juntos trabalhando de novo, com essa pessoa que a gente está até hoje. É uma coisa boa. É complicada, mas é legal, chega a ser divertido. É como em uma família...

Por falar em família, minha relação com a minha mãe é tranqüila, com meu pai não converso, acho que tem uns oito anos que não dou “bom dia” para ele, já com meu padrasto é totalmente diferente. Meu padrasto, o Barba, é o cara que ajudou minha mãe quando éramos pequenos, ao contrário do meu pai, que nunca apareceu nem para dar bom dia. Sei onde ele mora, fui uma ou duas vezes na casa dele, depois não fui mais, não dá liga entre eu e ele, é melhor ele ficar lá e eu aqui, porque a pessoa quando põe filho no mundo, seja lá por querer ou sem querer, tem que assumir, tem que ser responsável. Meu pai nunca fez porra nenhuma, minha mãe sempre trabalhou, teve que pagar gente para cuidar de mim, das minhas irmãs que também eram pequenas.

O Barba é bem-vindo na minha casa, é uma pessoa que está comigo direto, sempre que eu vou lá, que preciso, ele estende a mão. Às vezes ele vem aqui, estendo a mão para ele também 
e nos damos muito bem. Agora com relação a meu pai, não posso ficar perto dele nem cinco segundos, que eu acho que dá briga. Quero Genivaldo Sousa Santos bem longe de mim, a quilômetros de distância! Ele trabalha, tenho irmão e irmã que moram com ele e não recebem ajuda alguma. Agora parece que ele saiu de casa, sei lá o que aquele sujeito está fazendo da vida. Ele é um baiano bem seguro, mão fechada, não dá o braço a torcer nem para os que moravam com ele lá, imagina para nós aqui. Não tenho nenhuma lembrança boa dele.

Meu pai morou comigo até quando eu tinha dois, três anos, aí minha mãe deu uma surra nele e ele foi embora e não voltou mais. Deu uma surra porque ele tentou bater nela. Depois disso, só voltei a ter contato com ele quando já estava com meus 12, 13 anos, por aí. Não lembro de nada dele, ele nunca morou comigo, não teve participação em nada.

Minha mãe fez o papel dos dois, foi mãe e pai um bom tempo, até meu padrasto aparecer, tanto que o chamo de pai hoje. Às vezes grito: “Ô velho, ô pai!”, mas é diferente. Acho que se meu pai visse isso não iria gostar, mas ele não tem que gostar ou desgostar porque nunca participou de nada, nunca comprou um remédio, minha mãe se virou sozinha. Ele fica sem direito, é complicado para o lado dele. Para mim ele tem que viver longe. Minhas irmãs sempre iam lá, mas nunca tive vontade de ir, fui apenas duas vezes, contra a minha vontade. Às vezes minhas irmãs ligavam para ele, ele dizia que queria falar comigo, mas pô, ele sabia onde eu morava - agora ele não sabe mais - poderia vir se quisesse mesmo falar comigo. Se ele vier para cá também ele bebe, fica bêbado, enche o saco da minha mãe, então é melhor ele lá na vida dele e eu e minha mãe aqui. A Laura é quem liga para ele de vez em quando, porque morou lá.

Dos filhos homens de minha mãe sou o mais velho, depois vem o Cássio e em seguida o Rodolfo. O Rodolfo é o caçula dos homens e a Carol, a caçula das mulheres. Minha irmã mais velha se chama Luciana e faz tempo que não a vejo. Depois dela veio a Laura, que é muito teimosa. Agora está menos teimosa, mas quando era mais nova era terrível, só queria saber de festa. Minha mãe nunca nos proibiu de ir a festas, participar de baladinhas, essas coisas, só que ela falava para a Laura: "Laura, você vai para o salão hoje, só que em tal hora você esteja em casa porque amanhã cedo tenho que trabalhar e você tem que olhar os seus irmãos”. Ela só aparecia quatro horas depois do horário combinado, isso foi irritando minha mãe, até que um dia ela chegou no limite e cortou as diversões da Laura. Fez a Laura ir morar com o nosso pai. E só ela mesmo para conseguir morar com ele...

Não penso em me casar, acho que esse negócio não é para mim, mas quero sim constituir família. Quando eu estiver com uns 32 penso em adotar um filho. Queria mesmo uns três, quatro, de preferência já grandes, porque dá menos trabalho, já entendem as coisas quando a gente fala. Acho que ter família é normal, vai chegar uma hora que vai ter que acontecer, vai ter uma hora que me ajunto com uma doida aí. Morar juntos é bem melhor do que casar porque se 
não der certo cada um pega suas coisas e procura seu rumo. Não acho muita graça em casar, não. Até porque esse meu amigo Diego se casou tem quatro meses e já brigou, já deu tiro na mulher, uma guerra. Dessa guerra do casamento pretendo ficar fora por um bom tempo, até porque a mulher que estiver esperando casar comigo na igreja vai se aposentar. Quando duas pessoas se gostam se juntam e pronto, penso assim. Não sei se é porque não gosto de casamento, dessas coisas...

Gosto de criança pequena, dos outros. É legal criança pequena, a Caroline, puxa, é legal até demais! Ela faz uma baguncinha por umas cinco crianças. Ter filho também, acho que no máximo um, dois, já estaria bom, porque veja bem: se eu tivesse um filho agora ele iria ser criado como? Como eu fui criado? Eu trabalho, viajo muito, nem sempre estou aqui, ia ficar complicado para o lado da criança, então acho que quando eu estiver com uns 32 anos pode ser, ai tenho dois, adoto uns três, quatro. Seis filhos está bom. Fabrico dois e adoto o resto, é bem melhor adotar do que fazer, tem muita criança esperando adoção, esperando pai e mãe, se bem que para adotar é uma complicação danada, mas em todo o caso daria mais futuro. Pegar uma criança que não tem família, não tem pai, não tem mãe, não tem ninguém. Essa criança não tem praticamente nada e você dá tudo, torna tudo diferente. Você pode pensar em ter seu filho, um filho que é seu e tudo, mas uma criança adotada também é seu filho. Você adotou, pegou os documentos todos, é seu filho, não tem mais como voltar atrás. Acho que dá mais futuro adotar uma criança do que fazer um filho, agora se acontecer um acidente, a menina engravidar, aí tranqüilo, tem que assumir e pronto. Queria construir uma casa grande com um quarto para cada um, encher de brinquedo que aí pelo menos quando eu estiver trabalhando ninguém sente a minha falta.

Acho que não senti muita falta do meu pai, porque tive meu avô, minha avó. Éramos uma família no Piauí. Morei lá dos meus quatro aos sete anos e do meu pai nunca senti falta de modo algum! Sem chance! Nunca me bate saudade dele, tanto é que se alguém tocar no assunto eu lembro, mas se não nem lembro que ele existe. Acho que ele passa batido. Da minha mãe sinto saudade quando estou trabalhando, uma, duas semanas viajando por aí já me deixa com saudade. Também sinto saudade dos meus irmãos, da Carol principalmente, porque todo dia quando saio, ela chora pra caramba e quando volto é ela quem abre a porta para mim. Tenho saudade deles, agora do meu pai nem um pouco. Ele é meu pai porque assim: por causa dele eu estou aqui, dele e da minha mãe, mas ele é meu pai só porque me fez. Do resto não participou de nada, ele não sabem nem que um dia eu tive dor de dente, acho que ele não sabe nem a data do meu aniversário, que é primeiro de Março.

Tenho saudades da Laura também, mas é bem mais fácil, a gente se vê com freqüência. Fui uma vez lá na ocupação. Acho que não chega nem a ser saudade porque a gente está 
relativamente perto um do outro. Dá mais saudade da Luciana, que está longe e já tem uns três, quatro anos que não vejo. Tenho que ligar para ela sempre, ligo em dia de aniversário, feriado, final de semana. Ligo mais nos finais de semana e esse ano vou para lá de qualquer jeito, meu último trabalho é dia 12 de Dezembro, acabou, pego um avião, embarco e vou para lá porque tem uns quatro, cinco anos que não a vejo. Ela teve um filho. Tenho um sobrinho que ainda nem conheço.

Cada um tem uma opinião, do meu ponto de vista a militância da minha irmã Laura e do meu cunhado Tonho é uma perda de tempo, mas sei que nem todo mundo pensa assim. Você fica correndo o tempo todo de um lado para o outro, vai em prefeitura daqui, prefeitura dali e ninguém está nem aí para você, ninguém está se preocupando com você estar lá acampado, sem recursos. Acho isso uma bagunça, se fosse uma coisa mais organizada, mais pé firme... Então para mim tanto faz, tanto fez. Não concordo com isso de você ter que morar em cabana, em barraco, essas coisas de lona, Deus me livre! Posso um dia chegar a precisar, estar em uma situação assim, mas acho que a saída é o trabalho. Ela pode muito bem arrumar um emprego e alugar uma casa. Já tem uns dois anos que a Laura está atrás disso e nunca saiu do mesmo lugar, não deu um passo à frente ainda, então acho que é perda de tempo. Sinceramente, não daria um dia do meu tempo para estar correndo atrás disso sem ter certeza que dali tiraria algo útil para mim e para todos.

Sei que a falta de habitação é um problema político - e esse é o problema... Político, no meu ponto de vista é tudo safado. Você tenta votar em um fulano de tal achando que vai ser legal, chega lá o cara vira. Muitos votaram no Serra, eu não votei no Serra, ele saiu antes de completar um ano e colocou o Cassab no lugar, que está ferrando com todo mundo, principalmente comigo, que preciso trabalhar, que dependo de transporte público, como é o caso dessa situação do bilhete único e essa coisa toda que ele anda movimentado aí. Para mim isso é coisa de quem não tem o que fazer. Ele é outro que não tem o que fazer, que ganha dinheiro para ficar sentado. Político para mim... Você tenta confiar em alguém, mas não sabe em quem. Já cheguei a pensar: “A, vou lá e vou votar em qualquer um que aparecer, qualquer um vai ganhar mesmo”. Todos roubam do mesmo jeito, todos complicam do mesmo jeito, então eu não...

Nem sei muito falar de política, porque para mim são todos farinha do mesmo saco. A melhorzinha que vi fazendo alguma coisa foi a Marta, que passou quatro anos. Sou até meio fora desses assuntos, não costumo acompanhar essas coisas: o que os políticos estão fazendo, não me interesso muito por isso porque o que estão fazendo não está me adiantando em nada. O que a Marta fez me adiantou: um corredor de ônibus porque agora não pego mais tanto trânsito para ir trabalhar, mas o resto que eles estão fazendo, derrubando, medindo rua, construindo sei lá o que... Vão construir um mercado logo mais aí na frente, não é nada do meu interesse. Se eles 
estivessem fazendo casas: “A, vão derrubar a favela e construir casas, construir apartamentozinhos e dar para as pessoas”, seria uma coisa interessante, mas político não pensa em pobre, político pensa em dinheiro e no seu voto, é claro.

No tempo de eleições são mil e uma histórias, o cara conta que o Papa vai vir para o Brasil, que o bispo não morreu, inventa mil e uma histórias, você vota, e depois que vota é complicado. Votou não tem como correr atrás, aí complica toda a situação e a cidade fica cada vez mais um caos.

Gosto de São Paulo, mas não desfruto porque não tenho muito tempo e é raro eu estar por aqui. Gosto mais do Rio de Janeiro, porque quando vou para lá, que tenho um, dois dias de folga entre uma apresentação e outra, passeio muito. Acho o Rio mais interessante, mais marcante, você anda de bondinho, vai ao Cristo, ao Pão de Açúcar, tem outras opções. Aqui também tem bastante opção, mas o tempo é mais curto. Você tem que correr, resolver um assunto de trabalho aqui, outro ali, acaba perdendo o dia. Meu dia aqui é só para resolver assunto de trabalho e mais nada, mas quando estou viajando gosto de ir a muitos lugares, desbravar, revirar a cidade de cabeça para baixo.

Morei em Jangadeiro, um bairro que tem logo ali embaixo, uma região de Capão Redondo. Jangadeiro foi o lugar onde cresci, praticamente. O pessoal fala que o Capão Redondo é perigoso, que Jardim Ângela é perigoso, mas me criei aqui e estou vivo até hoje, então não é o lugar que é perigoso, são as pessoas que o tornam perigoso, as pessoas incorretas. A escola onde estudei é aqui atrás de casa.

Tenho muitos amigos da época em que morei no Jangadeiro e quando não estou aqui estou lá. Aqui conheço bastante gente, mas quando não estou trabalhando vou para lá, passo o dia inteiro, só venho para cá de noite. Ali é um lugar especial porque foi onde me criei.

Meu lugar favorito em São Paulo é o Parque do Ibirapuera, mas já tem uns dois anos que não o visito. Antigamente freqüentava bastante, achava legal, batia uma bolinha lá toda tarde, mas isso também há dois anos, quando peguei dois meses de férias. Também aprecio essa região do Ângela, do Capão Redondo porque foi aqui me criei. Uso esse boné azul escrito “Capão Redondo” porque ele é um símbolo da nossa comunidade. Tem umas trezentas e poucas pessoas que usam bonés iguais a esse, e logo mais vai sair moletom, camiseta e essas tranqueiradas todas.

Faço parte do grupo denominado “Os Perturbados”, mas há outros, como "Família Veiga”, “Os Perversos”, e a cada dia aparecem novos grupos. A coisa de fazer o boné para nos identificarmos surgiu em uma roda de amigos, a gente estava conversando em uns oito, nove e chegamos ao assunto de fazer boné bordado, fomos pensando, pensando, levou uns dias, aí os 
caras foram fazer desenho, o próximo que está para sair tem o logotipo. Cada um apresentava uma proposta e até escolher o desenho levou um tempo. Adoro boné, eu durmo de boné!

Meu diretor fala que somos uma gang, realmente é como se fosse uma gang, mas no bom sentido. É uma comunidade. Uma gang no lado bom, não no lado negativo. No mesmo bairro tem três grupos diferentes, que são Os Perturbados, que nasceu no mesmo dia que a Família Veiga, e agora tem também Os Perversos.

Não há briga entre esses grupos porque são todos do mesmo lugar, um respeita o outro. A gente faz festa envolvendo as três partes sem problema algum, não é uma gang para bater em outra, é normal, é apenas uma forma de expressão de identidade: “Eu sou de tal grupo”, “Eu sou de tal grupo”, "Eu sou de tal grupo”, mas gente se envolve na bagunça sem problema algum e nunca essa coisa de segregação, de violência. Nunca tivemos problema. Tenho esse boné há uns sete meses, mas já deve ter uns dois anos que isso está rolando. Ainda não sei como vai ser o desenho, o logotipo, não tive a oportunidade de ver, mas estou curioso. O menino que fez esse desenho é lá do Independência. Estavam em três, um do Independência, um do Ângela e um de Itapecerica da Serra. Eu achava o logotipo daqui mais bonito, mas não tive oportunidade de ver ainda o que foi escolhido porque o salão onde a gente coloca as coisas e senta para conversar, tomar as decisões, está fechado. Logo nossas camisetas vão ficar prontas, vamos ver se vão ficar legais, se vão ficar bonitinhas. É uma coisa que a gente faz para a gente mesmo, e não na intenção de ganhar dinheiro, vender. É uma forma de expressarmos nossas idéias, colocar em prática e ver como é que fica.

O trabalho de confecção é feito por uma mulher lá no centro da cidade, conhecida de um colega do grupo. Ele faz a compra do material de acordo com os pedidos e leva para ela bordar. Esse trabalho da bordadeira tem um custo, para ele comprar também tem um custo, então a gente colabora. Paguei R\$: 25,00 nesse, então suponhamos que saia há R\$: 12,50 para cada parte: para a mulher que borda e que tem todo aquele tempo despendido para bordar 40, 50 bonés todo dia, na máquina - uma coisa que deve ser muito cansativa, e o trabalho dele, o tempo gasto nas compras, no ir levar para a bordadeira, a condução, o almoço - porque ele tem que almoçar, não tem como passar o dia inteiro na rua sem comer - então a gente tem que concordar com todas as partes. O cara tem que almoçar, tem que pagar o transporte, a mulher tem o custo dela para bordar, o cara que vai comprar o boné tem que negociar, é longe pra caramba, então a gente bota a mão no bolso, cada um dá 25, 30 e vai rolando o negócio.

A cor original dos bonés era azul bebê, esse meu azul não é o original. Cada um escolhe a cor que quer, mas tem que ter um original. Não tenho ainda, não comprei, mas vou comprar na próxima semana. Você pode variar nas cores, é só escolher, tirar a medida e encomendar. Pode colocar um preto, vermelho com letras azuis... A encomenda fica pronta em três dias. 
Nossa família está crescendo, tem mais ou menos umas trezentas pessoas, e nossos símbolos também: agora já tem até adesivo para colar no vidro do carro. Se estou trabalhando, quem está em casa vai lá, negocia, vê quanto custa, traz as opções de letras, a gente entra em um acordo, vê qual é a melhor e vai fazendo. Agora que saiu o adesivo vai sair o moletom, para o próximo mês vai estar pronto. É divertido, a gente se distrai um pouco. Nossa família está crescendo e acho que isso vai longe, que vamos ter muitas histórias para contar.

Minha vida é assim: trabalho e diversão. Acho que não contei que trabalhei em casa de show, né? Foi uma temporada curta, três ou quatro meses, ma foi bom porque fui aprendendo a mexer com som, com luz. Trabalho e música são tão importantes na minha vida como comida. E por falar em comida, adoro miojo e pão, se eu pudesse comeria miojo e pão o dia inteiro! Esses dois alimentos são fundamentais para mim.

Tem muita coisa que não gosto de comer: feijão preto, cebola, não como nada que tem cebola. Gosto de alho, comida com alho é bom, agora não gosto de feijão preto, feijão preto para mim não desce em hipótese alguma, se for uma feijoada eu até como se for um dia só. Pense bem, na última vez que fui ao Rio de Janeiro passei 12 dias, lá não se come feijão branco, então complica a situação. Acarajé, essas comidas assim eu não gosto. Comidas da Bahia raramente consumo. Não sou vegetariano, mas gosto muito de alface. Se tivesse alface para comer todo dia acho que não comeria feijão todo dia. Não como arroz com feijão apenas nem brincando, Deus que me perdoe. Prefiro comer macarrão, se não tiver mistura para eu comer faço macarrão, se não tiver macarrão eu não como, vou para a casa do Diego e como lá, porque a mãe dele faz macarrão todos os dias, mas feijão e arroz puros eu não como, não desce, não dá liga, agora miojo como a qualquer hora, porque é prático, rápido.

Gosto muito de vinho, whisky, cerveja, vodka, só não gosto de 51, essas cachaças puras... De frutas gosto de maçã, abacaxi, raramente como banana e não aprecio uva. Consumo frutas de vez em quando.

Lá no Piauí alimentação era um problema porque a comida é toda diferente, lá tem carne suína direto, animais matados na hora, mas tirando o feijão com gostinho de terra eu comia de tudo, sem problema algum. Foi tranqüilo, não sei se porque passei pouco tempo... Tirando o feijão de lá que eu não gosto... Mas também não gosto do feijão daqui, então não dava muita importância. Lá a gente comia muito cuscuz, muita carne de porco. Como qualquer coisa com carne de porco, se possível até pãozinho com carne de porco, gosto dela frita, torrada, assada, de qualquer forma, menos crua. Ah, outra coisinha que não como nem brincando é carne de cabra, bode, porque têm cheiro de mijo, é horrível, não desce! Sou meio enjoado para comer, se eu ver que não está muito bem não como. Se eu perceber que a mãe colocou cebola na comida, fuço a comida todinha até tirar todos os pedacinhos de cebola, maionese, se for caseira também não 
gosto, agora se for uma maionese tradicional, sem muita tranqueira até gosto. Partiu para essas coisas muito complicadas feitas em casa já fico receoso, no mínimo deve ter cebola. 


\section{Marcos}

\section{“É importante saber se olhar no espelho, reconhecer a própria imagem, os erros e as virtudes"}

Meu nome é Marcos, mas todos me conhecem por Boi, Boi Bandido e essa é uma longa história que prefiro contar depois. Estou no MTST desde a época da ocupação Chico Mendes, que desencadeou uma luta muito grande por reforma urbana nessa região de Taboão da Serra, Itapecerica da Serra.

Iniciamos a ocupação do terreno do Jardim Helena de madrugada, iluminados apenas por tochas que improvisamos. O “dono" desse terreno pretendia fazer lá um golf club e os prédios inacabados ao lado pertenciam a uma construtora que abriu falência e não devolveu o dinheiro que os compradores dos apartamentos investiram, estão em uma luta judicial. O fato é que o "dono" daquele terreno devia milhares de reais em impostos para a Prefeitura, porque na vida do pobre é assim: se dever cinco anos de imposto a Prefeitura vai lá e toma o imóvel, mas o rico não! Como o proprietário não pagava imposto há muitos anos, aquele terreno deveria pertencer à Prefeitura de Taboão da Serra e nessa cidade existe uma lei que diz que não pode ter morador de rua, então porque não poderíamos ocupar?

Sou contra a palavra invasão, não fazemos invasões, fazemos ocupações de terrenos que estão desocupados e não cumprem sua função social. Entramos em uma coisa da Prefeitura, que tem que cumprir seu papel, fornecendo, neste caso, bolsa aluguel, casa popular, e é uma coisa que não faz!

O estereótipo de que sem-teto é vagabundo é comum, eu mesmo, pouco antes de entrar no Chico Mendes falava: “Bando de vagabundo!” Mas quando entrei meu conceito mudou. Para mim aquilo era sinônimo de vagabundagem, hoje é de luta! Comecei a conviver com as pessoas, vivemos lá nove meses, lutamos muito, sem água, sem luz, sem isso, sem aquilo, debaixo de lona preta porque lá não podia fazer barraco de tábua, o prefeito, os vereadores, os deputados desfazendo da nossa pessoa, chamando a gente de vagabundo, mas na verdade vagabundo são eles, porque recebem o salário que pagamos e não fazem nada por nós!

De lá fomos para o Valo Velho. Muitas pessoas do Chico Mendes, pessoas lutadoras foram para a ocupação de lá, chamada Comunidade João Cândido e nela conheci pessoas maravilhosas como a Lady, a Laura e a Michele, que estão ao meu lado neste momento.

No Chico Mendes havia aqueles prédios abandonados ao lado, mas não os ocupamos. Ele servia apenas para os crimes cometidos na cidade: desova de corpos, depósito de carros e motos roubadas, policiais matando pessoas inocentes que confundiam com criminosas, mendigos, eu mesmo já apanhei lá dentro, e deixo claro que não tenho passagem pela Polícia. 
Meu carro poderia ser desmontado lá, minha filha poderia ser estuprada lá dentro, mas eu não podia ocupar para morar se eu não posso pagar o aluguel? Isso a Justiça não vê! Aqueles prédios não têm estrutura, não seguram o número de andares que possuem, pois é uma mina d’água. Ali do lado tem uma mina que comprova isso, água contaminada, inclusive, que crianças de rua bebem, por isso que tem muita doença em Taboão da Serra.

Fazíamos a organização do Chico Mendes da seguinte maneira: tínhamos três portarias, então a gente se revezava, chamava três companheiros, que acampavam para cuidar da portaria das seis da noite às seis da manhã, e outros companheiros cuidavam das seis da manhã às seis da noite. Para que isso? Porque na Polícia infelizmente há alguns que são folgados, queriam entrar, bater, então tínhamos que fazer nossa própria segurança. Não entrava carro a partir de certo horário, para não entrar carro roubado, moto roubada. Além da portaria tínhamos a Ronda. Nosso pessoal fazia a ronda entre os barracos, para evitar, por exemplo, que o cara mate a esposa dentro do barraco, porque tem homem que é folgado e tem mulher também que é folgada! A gente evitava aquilo: “Ó, péra aí companheiro, não é assim que funciona, aqui é uma comunidade de paz. Aqui dentro não, lá fora você faz o que você quiser, agora aqui dentro tem que ter respeito!”

Tivemos muito problema de violência doméstica, mas sempre conseguimos contornar e evitar que desgraças acontecessem. Tínhamos também uma lei de horário: dez horas da noite som desligado, sem bagunça nas ruas, porque de repente não vou trabalhar amanhã, mas meu vizinho do lado vai, então tenho que respeitá-lo e respeitar seu horário, pois ele tem que descansar! Era uma regra nossa.

Pregadores a gente não aceitava lá dentro: "Quer conversar, chama a Militância”. Bebida era liberada sexta e sábado à noite, porque a gente também precisa se divertir, mas no resto dos dias não, quer beber, faça dentro do seu barraco, mas na rua, não! No seu barraco você pode beber, cair, fazer o que quiser, mas na rua dos acampamentos não, tem que respeitar! As bocas $^{45}$ que tinham... Aproximamos-nos dos homens e conversamos. Tinha os playboys que vinham de fora para comprar lá dentro e dissemos a eles: “Óh, é o seguinte: quer comprar, não tenho nada a ver com a sua vida, mas fumar aqui não! Na frente de criança e senhora não vai fumar, não vai fazer xixi, não vai puxar arma, aqui tem que ter respeito!”. Infelizmente não podemos evitar essas coisas, não tem como evitar, mas tem como controlar, e eles respeitam isso.

Somos um Movimento sério, muito sério mesmo! Somos contra quebrar cerca, então nós não vamos fazer cerca... Domingo passado um cara falou: “O time da favela ta jogando bem!” Eu falei: “Time da favela, não! Comunidade João Cândido! Não é favela, a gente já luta para acabar com favela, não vou aceitar essa palavra! É Comunidade João Cândido, periferia, que é diferente!” Prefiro estar aqui dentro e ver a vida de cada um do que estar dentro do meu

\footnotetext{
${ }^{45}$ Bocas de Fumo.
} 
carro ou do meu apartamento isolado, com medo de sair na rua, porque os presos hoje são as classes média e rica, que ficam trancadas em suas casas, em seus condomínios, com medo de sair para comprar um pão, comprar crédito para o celular, nós não! Tenho medo sim, da Polícia, porque me bateram, me cataram na rua aqui e desceram o pau! Foi em um dia que estava tendo ato e também Rodeio de Itapecerica, a viatura da Tática parou ao meu lado, dela desceram quatro homens e ó: cacete comeu, cacete comeu mesmo! Cheguei aqui todo quebrado, quem cuidou de mim foi a Fran, o Rodrigo e a Bárbara. O que fazer depois disso? Registrar ocorrência para quem? Apanhando não consegui ver a placa, não consegui ver o número da viatura, só vi os homens e eles sabem bater, não deixam marca, isso foi numa sexta-feira, aí vou esperar até segunda para fazer um exame de corpo de delito? Não adianta, então a Polícia para mim é uma merda, isso é que é a verdade!

Estar no Movimento não é fácil, mas nossa vida não é só luta e sofrimento, temos cultura também, culturas bonitas! Aqui por exemplo, montamos as $\mathrm{MDs}^{46}$, montamos nossos saraus, nos quais representamos a luta de companheiros como Zumbi dos Palmares, Maria Bonita, pessoas que lutaram mesmo. A gente tem diversão também, mas essa diversão é feita por nós mesmos porque quem tem dinheiro aqui para pagar dez reais e ir ao cinema assistir um filme de uma hora? Ninguém tem, então fazemos nosso sarau, nosso cinema, os documentários de nossa história e organizamos atividades com as crianças.

A Ciranda é quem cuida das atividades com as crianças. Não está funcionando no momento porque nossos professores e voluntários estão em outras atividades, mas temos aqui uma Ciranda, onde se dá aula para as crianças, não tem vaga lá na Escola, mas aqui no acampamento tem! Temos professores para ensinar a ler e escrever, a falar e escrever poesia e isso é muito legal! Temos uma cozinha comunitária, a gente ganha doação, mas não a enviamos para os barracos individuais, pois preferimos utilizá-la coletivamente. Se uma pessoa está sem gás para cozinhar no seu barraco, pode usar o fogão da cozinha coletiva, se está sem feijão, pode comer o feijão preparado nesta cozinha e todos são responsáveis por ela, ou pelo menos deveriam ser. Estou aqui com pomadas para assadura de crianças, quem pode traz esse tipo de doação porque nem todo mundo pode comprar hipoglós e se a gente for depender do Governo, da Saúde, da Polícia, a gente ta tudo fodido!

Nós mesmos cuidamos de nossa saúde com uma medicina doméstica, com chás, com plantas, não sabemos direito como funciona, mas fazemos e acaba dando certo! Esse ânimo de fazer as coisas, mesmo com pouco é o que nos mantém vivos, o Tonho, por exemplo - que chamo de paisinho, porque é meu pai dentro do Movimento, é quem me orientou - fala: "Vai ter o sarau, não tem ninguém, mas vamos fazer assim mesmo! Se colher uma pessoa já ta bom e o

\footnotetext{
${ }^{46}$ Meninas Dançarinas, nome de um grupo de danças composto por moças da Ocupação João Cândido.
} 
sarau vai ter que acontecer!” Todo o sábado temos sarau. Se você sabe falar uma poesia, você vai lá à frente e fala, se sabe tocar um violão errado que nem eu, vai lá e toca, é assim que funciona.

É preciso mostrar nossas habilidades e vencer nosso medo interior. Você, na sua casa tem vergonha de falar com a sua mãe que você sabe fazer uma poesia, mas para os outros não, você vem e mostra o que sabe fazer. Nós gravamos um CD: Inimigos do Ritmo. Temos um CD gravado, sem-teto fez isso! Por que só os ricos podem fazer? Nós temos talento! E precisamos cada vez mais aprender a por esse talento para fora, e é o que está acontecendo!

Aqui ao meu lado estão a Michele, a Laura, minha "mainha” e a Lady. Estas meninas dançam muito bem! Foi uma luta para montarem o grupo de dança, mas quando as viram dançando, pagaram um pau, porque elas têm talento! Em dois dias e meio ensaiaram uma dança afro e apresentaram na comemoração dos seis meses dessa ocupação de modo que mexeu com todo mundo! Fui uma das pessoas que as criticaram antes de ver a apresentação, errei porque sou muito rígido, sou rígido mesmo. Não sei dançar, não sei cantar, não sei fazer porra nenhuma, o que sei é pegar no pé! Fui ignorante com as meninas diversas vezes, uma vez até tive que pedir desculpa para elas de tão ignorante que fui, mas penso que pela minha ignorância, pela minha exigência e as cobranças que fiz, vi esse resultado tão bom. Essas meninas são dez! São competentes e essa é uma cultura que nasceu dentro do Movimento, não foi lá fora, foi aqui dentro.

Não estou muito presente no acampamento nos últimos dias porque preciso trabalhar. Conquistamos esse terreno para a construção das moradias, mas não sabemos como vai ficar, quando vai ser a construção, onde essas pessoas vão ficar nesse tempo, se vai ter bolsa-aluguel, alojamento, ainda não sabemos nada, mas a expectativa é muito grande! Algumas pessoas fazem a pergunta: “O que você acha melhor: prédio ou casa?” Acho melhor prédio porque aproveita mais o espaço. Penso o seguinte: tem esse barraco aqui, certo? Eu moro aqui, em cima vai ter uma outra família, em cima dela vai ter uma outra família. Lá no Valo Velho havia três mil famílias, aí sai aqui quinhentas casinhas, quinhentas vezes três dá mil e quinhentos, vezes seis dá três mil casas. Se for prédio dá para abrigar todas essas famílias, se for casa o espaço é insuficiente e o importante é tirar as pessoas da rua. Sou a favor de fazer prédios de andares, que são de cinco no mínimo e cada andar tem pelo menos três apartamentos.

Moro em apartamento, detesto, só que no nosso caso acho melhor porque em vez de você abrigar uma família, você agrupa quatro. Quanto à questão da limpeza, vai ter uma pessoa responsável embora todos devam zelar por isso.

Teve uma reunião comigo aqui porque cheguei e vi neguinho colocando saco de lixo na porta, então saí pelo acampamento e falei: “Esse acampamento está um lixo!” Não fiz isso por 
maldade, fiz por realidade! Não vai quebrar a mão a pessoa pegar uma porcaria de um saco de lixo e levar lá em cima na lixeira, mas tem que deixar aqui na porta? Não! Não pode fazer isso!

A vida é assim: a gente nunca sabe o que está à nossa frente, o que nos espera. O Movimento para mim era um bando de vagabundo, um bando de cachaceiros. Quando entrei já tinha virado cachaceiro, essa que é verdade, eu era um tremendo de um cachaceiro que só sabia criticar, mas hoje dou a minha vida pelo Movimento! Tem gente que fala que estou aqui pela cachaça, fala brincando, né? Tenho casa, estou aqui pelo Movimento, pelas pessoas que aprendi a amar, não é pela cachaça, porque cachaça bebo em casa.

Certa vez, lá no Chico Mendes, tirei o Gabriel das mãos da Polícia, hoje nem consigo imaginar como fiz aquilo, mas fiz! O soldado Nóia o pegou e eu fui em cima, o empurrei e puxei o Gabriel, mas um dos pés do tênis dele ficou lá, e ele disse: "Pô, eu só tenho aquele tênis!" Voltei para buscar o tênis do menino.

No dia do Rodeio a Tática me parou em uma rua de terra aqui perto, encostou: "E aí porra, você não tava folgando lá? Você não tava lendo um livro?”. Inclusive o livro está até aqui. Me bateram muito porque estava carregando um livro! Se eu tivesse medo não voltava aqui. Medo eu tenho, mas tenho coragem também! Quantas vezes não puxaram faca para mim, não puxaram arma: “Agora você vai ter que sair porque você é folgado, você é isso, você é aquilo”, mas não é questão de ser folgado, é questão de ver a realidade e querer o melhor para a pessoa. Qual é a mãe que não puxa a orelha de um filho e não dói nela? Se a pessoa for mãe dói, então esse é o nosso Movimento!

Uma vez apanhei da minha mãe porque ela tinha me dado um moletom novo de presente e chegando à ocupação Chico Mendes vi uma senhora com frio e dei minha roupa para ela. Minha mãe ficou zangada, disse que nunca mais me daria nada, e me sovou. Mãe é mãe!

Muitas coisas que procuramos ao longo da vida, só encontramos depois de luta. Depois você vê, entende. Criticar uma pessoa é muito fácil, mas reconhecer os próprios defeitos não é.

Conheço uma brincadeira, uma mística que ajuda muito na autocrítica. Você pega uma caixinha, coloca um espelho dentro e coloca também papeizinhos com os nomes das pessoas presentes. Aí cada pessoa vai tirar um papelzinho e falar a principal qualidade e o principal defeito da pessoa cujo nome está escrito nele, mas se esquece do espelho que está dentro da caixa e reflete sua própria imagem! Todo mundo acha que está falando sobre o outro, mas não! Na verdade, está falando de si próprio, de seus defeitos e qualidades, está se olhando no espelho. É importante saber se olhar no espelho, reconhecer a própria imagem, os erros e as virtudes, é preciso ver as virtudes também, ver a beleza. Não podemos ficar nos menosprezando, assim como não podemos ficar projetando nossos defeitos nos outros, criticando os outros. É preciso se 
enxergar! Como vou te criticar se também estou errado? Agora se não tiver um espelho para me olhar, vou te criticar a vida inteira e achar que estou sempre certo!

Aprendi essa mística na vida. Morava no Rio de Janeiro com um cara que vivia me criticando, apontando meus defeitos, meus erros, me humilhando mesmo, até que um dia cheguei em casa e vi que ele estava chorando na frente do espelho e conversando com sua própria imagem. Ele dizia para si mesmo: "Isso que você fala sobre o Marcos é um problema seu e não dele. Esse erro é você que comete, esse defeito é seu mesmo”. Mas comecei a ver que ele só confessava os defeitos dele ao espelho e depois continuava nos cobrando pelos erros que ele cometia, então falei: “Não, não pode ser assim, vamos fazer diferente a mística!”. Achei aquilo muito interessante e comecei a refletir sobre como criticamos os outros, temos dificuldade em reconhecer nossos próprios defeitos, os projetamos nos outros e os culpamos por tudo. Trouxe essa experiência para o Movimento, fizemos muitas vezes, sempre temos uma caixinha e um espelho por perto. O MTST é isso: cultura, luta, ensinamento! 


\section{Lady}

\section{“Minha filha é minha vida”}

Antes de entrar na ocupação do Valo Velho eu morava com minha mãe, no terreno da casa dela. Tinha alguma liberdade, só que tenho uma filha e minha mãe é muito chata! Pelo fato de a casa ser dela eu não podia receber todos os meus amigos. Minha mãe implicava comigo e minha madrinha também. Minha madrinha é mãe da Laura, minha melhor amiga, com quem ingressei no MTST.

Como sou mais velha que a Laura, a mãe dela achava que eu a arrastava para o mau caminho, aquela coisa: sou mais velha, já tinha uma filha... Mas na verdade ninguém arrastava ninguém, a gente simplesmente combinava de sair. Sempre tive responsabilidade com minha filha, mas minha mãe falava assim: "É, qualquer hora você vai sair você vai ver, não vou nem falar nada!” Quando a Laura chegava ela começava a xingar aí eu falei: “Laura, sabe de uma coisa, a gente trabalha, vamos sair daqui? Vamos alugar uma casa e vamos embora!” Fizemos isso, levei minha filha comigo e enquanto estávamos trabalhando estava tudo bem, mas depois ficamos desempregadas e passamos a morar um tempo com amigos. Em seguida moramos com a nossa família novamente.

A relação com minha mãe estava difícil, eu estava meio sem noção do que fazer. Quando ia para a casa dela, ela dizia: “Ah, deixa a menina aqui comigo e não sei o que!” Um dia me arrumei, fui para lá e ela me disse: “Oh, Lady, você ficou sabendo que tão invadindo um terreno lá no Valo Velho? Por que você não vai lá ver se arruma um lote pra você? Melhor do que ficar pagando aluguel!” Eu disse: “Ai, vou lá sozinha? Vou ver com as meninas” As meninas eram a Laura e a Paloma. A única que estava trabalhando ainda era a Paloma. Eu falei: “Ah! Vamos!” Para não irmos sozinhas, passei em casa e chamei meu irmão mais velho. Fomos morrendo de medo porque era algo novo na nossa vida. Chegando lá vimos aquele mundo...

Primeiro ficamos emocionadas! A gente não sabia o que era aquilo, nunca tinha imaginado uma coisa daquelas! Um monte de lona, muitas pessoas chegando com bambu, com lona, uma movimentação incrível! Mas a gente não conhecia ninguém. Eu achava que a gente não conhecia ninguém naquela ocupação, fui andando, andando, andando, aí quando chegou lá no G25: um monte de amigos meus, um monte mesmo! Tudo de onde eu morava! Um deles falou: “E aí Lady? E aí loira, e aí loira?” Aí falei: “Aqui não vou ficar não!” Fui subindo e encontrei um amigo que é do Rio de Janeiro, veio passar uns tempos aqui em São Paulo, ficou sabendo da ocupação e foi para lá também. Foi através dele que conheci todos do Chico Mendes. Ficamos justamente no G2, que era bem na entrada, bem no comecinho. Todos dali eram do Chico Mendes, e nos apoiaram muito, nos acolheram como filhos mais novos. Eles falavam: 
“Ah, pessoal, não desiste não! Vocês não vão desistir, não é?” E a gente dizia: “Não vamos desistir não!” Mas era difícil. E para eu ver minha filha? Só podia vê-la de quinze em quinze dias, era um desespero ficar longe dela. Às vezes eu ficava chorando, o pessoal vinha: “O que você tem, Lady?” "Eu quero ir embora, eu quero ir embora, quero ver minha filha, não agüento mais ficar aqui!” Ia para casa, ficava dois dias com ela depois tinha que voltar, senão perderia minha identificação de acampada e as pessoas começariam a me chamar de andorinha. Sempre quando uma ia a outra ficava, uma ia a outra ficava cuidando para ninguém tirar a lona.

Laura e eu demoramos em nos decidir a ir para lá, mas quando nos decidimos, dissemos que não desistiríamos por motivo algum desse mundo, e é o que fizemos!

Passamos por muitas dificuldades na Ocupação: para começar a falta de experiência em construir nosso barraco, não sabíamos cavar buraco, pregar lona, nem nada disso, depois as dificuldades de nos mantermos lá: falta de recursos. Estávamos desempregadas e não recebíamos muito auxílio de nossa família, apesar de ter sido minha mãe que sugeriu que eu fosse para lá. Deixei minha filha morando com ela, não tinha como levá-la comigo, porque lá faltava água, luz, alimentos. Ficar longe da Maira - minha filha se chama Maira e tem três aninhos _ foi a coisa mais difícil que enfrentei.

Agora conquistamos esse terreno e nossas casas serão construídas, ainda não sabemos quando vai começar, mas esse foi um passo importante. Quando tiver minha casa vou poder realizar meu sonho, que é trazer minha filha para morar comigo. Ela está com a minha mãe, vem me visitar de vez em quando, passa o final de semana aqui. Ela fala que vai querer um quarto só para ela e uma televisão!

A gente não sabe ainda se vão construir casas ou prédios, mas prefiro que sejam casas porque em apartamento você não pode fazer bagunça, não pode fazer festa, tem menos liberdade e assim como a Laura, não gosto dessa idéia de ter um síndico chato chamando a atenção, acho que cada um tem que ser responsável por sua vida. Se for apartamento não vou querer ser vizinha nem do Boi nem da Laura porque eles não deixam ninguém dormir, adoram chegar de madrugada fazendo bagunça! Ele e a Laura são o fim!

Viver em uma ocupação, dentro de um barraco de lona é muito difícil, Laura e eu já passamos por poucas e boas. Teve vez de não termos dinheiro para condução e andarmos a pé vinte, trinta quilômetros. Muitas vezes falava para ela: “Ai Laura, a gente tem que ganhar essa casa porque já não agüento mais andar!” Hoje sou super preguiçosa, se me chamam para ir ali em cima ao metrô do Capão Redondo, sinto preguiça, mas para as passeatas e marchas eu vou, não costumo faltar. Fico imaginando o tanto que já andei em minha vida e sei que ainda tenho muito caminho pela frente! 
Estou na luta mais pela minha filha, por ela faço qualquer coisa. Ela mora com a minha mãe, minha mãe não a deixa aqui, mas me apóia, o que eu preciso posso ir até a casa dela e buscar, meus irmãos também me apóiam e nunca foram contra. Eles sabem que estou lutando por uma coisa certa, mas têm muito ciúme de minha filha e não querem que ela venha mais para cá. Tenho fotos dela aqui, depois mostro. Ela é a minha vida! Quando chego lá ela pergunta: “Mamãe, você vai voltar de novo para aqueles sem-teto?” As minhas amigas chegam lá, perguntam sobre mim e ela fala: “Mamãe ta morando lá no sem-teto”. “Ah e você?” "Eu não vou pá lá não!” Mas ela vem, passa aqui dois, três dias e quer voltar. Desculpe, estou muito emocionada. 


\section{Bárbara}

\section{“Queremos uma vida melhor para nossos filhos e para nossos pais, que já não agüentam mais trabalhar”}

Meu nome é Bárbara Teixeira de Sampaio, completei 23 anos ontem, dia 29 de Novembro. Estou nessa ocupação há mais de oito meses. Comecei lá no Valo Velho. Tudo começou com um amigo que estava acampado e pediu o meu auxílio. Ele precisava de alguém que tivesse os documentos em dia para poder fazer o cadastro e conquistar o espaço que ele desejava. Também tinha algumas amigas acampadas, com barraco pronto e tudo, e sempre ia lá para dar uma força a elas. De tanto participar de reuniões e assembléias fui me inteirando da vida naquele lugar, do projeto político do MTST e acabei me tornando uma acampada. Curiosamente, esse meu amigo desistiu.

Quando estávamos no Valo Velho fomos para o Palácio do Governo todos juntos, em marcha, organizadamente, foi lindo! Hoje, quando assisto ao DVD, não consigo conter a emoção e choro. Foi naquela marcha que me apaixonei pelo Movimento, comecei a participar intensamente, a devorar as cartilhas, os livros. As Assembléias eram importantíssimas porque por meio delas ficávamos sabendo o que estava acontecendo, o que deveríamos fazer e como seria o futuro de nossa luta. Nosso objetivo era claro: casa, moradia, mas também respeito, melhores condições de vida, saneamento básico, luz, parques, escolas, enfim, ter tudo o que qualquer trabalhador merece ter. Somos trabalhadores sem-teto, sem casa, sem oportunidade.

O Movimento deseja uma cidade melhor, inclusive, aqui não é mais um acampamento, aqui já é uma civilização. O que nos diferencia das outras pessoas lá fora é que saímos para lutar, reivindicar os nossos desejos e os nossos direitos. Queremos uma vida melhor para nossos filhos, para nossos pais que já não agüentam mais trabalhar, para os que não tiveram condições de estudar e hoje são marginalizados do mercado de trabalho porque não têm a formação necessária. A gente luta pelos pais que já trabalharam muito nessa vida, que estão em idade avançada e hoje não conseguem mais pregar uma madeira. Temos que cuidar deles porque afinal, eles cuidaram da gente.

No meu caso, não recebi muitos cuidados paternos, cresci dentro de um colégio interno no Jardim Olinda, no Campo Limpo: Colégio Batista. Entrei lá com dois aninhos, saí com nove. Apesar de ter estudado nesse colégio, minha família e eu somos católicas. Quando bebê, fui batizada na Igreja Católica, acredito também no Espiritismo, é meio complicado... Não me envolvo com nada, porém, acho que devo respeitar todas as religiões que são de louvor a Deus. 
Antes de eu vir para cá, de tomar esse lugar como acampada, morava na casa de minha mãe. Depois que conheci o acampamento João Cândido passei a praticamente morar lá: dormia, cozinhava, buscava lenha, fiz família! Nem falo amigos porque com amigos a relação é mais formal, a gente se vê por pouco tempo, não convive o tempo todo. Falo que fiz uma família aqui no Movimento porque moramos lado a lado, convivemos, tomamos café da manhã, almoçamos, jantamos juntos. Lá no Valo Velho eu cozinhava, buscava lenha, buscava água, fazia tremer mesmo! Cantava, ia para os atos com aquele orgulho, nunca tive preguiça. Ia a pé, cantando e voltava feliz! Fui de cabeça, porque o que faço na minha vida, não faço pela metade, faço de cabeça!

Raramente alguma família aceita ver os filhos em um acampamento, por mais que a vida lá fora também seja dura. Minha família não entende que estou lutando por uma coisa muito importante e que habitação é um direito de todos! Todo mundo deveria ter uma casa e um emprego, mas lá fora eles não entendem isso, tem gente debaixo da ponte, isso é vida? Será que é isso que está para o ser humano? Pobreza, doenças físicas e mentais e cadê o Governo em tudo isso? Não vou dizer que é culpa dele, mas é culpa dele não querer ajudar, não fazer por onde e tapar o sol com a peneira.

Nunca assumi papel de coordenadora, apenas ajudava, mas sempre fui para as reuniões da Coordenadoria e aprendi muito lá. Tenho os meus cadernos com tudo anotado e o que aprendi não é para eu ser ou deixar de ser alguma coisa. Foi uma aprendizagem, uma coisa boa para mim. Todos eram coordenadores porque todos tinham capacidade para isso.

Cheguei a esse acampamento como acampada e resolvi dar o último passo para fora da casa de minha mãe pelo fato de eu não aceitar meu padrasto, que é alcoólatra e está sempre querendo bater, querendo matar. Fiquei pensando: "sou uma pessoa que trabalha, se esforça, estuda, não tenho que ficar ouvindo essas coisas e passando por essas humilhações”. Não aceitei aquela situação, nunca me dei bem com ele mesmo, agora com minha mãe sim, graças a Deus a gente sempre se deu bem! Apesar de ter ido para o colégio interno, não a culpo. Sou ressentida, rancorosa em relação a isso sim, porém, não vou meter os pés pelas mãos.

Não é porque virei sem-teto que sou uma pessoa sem noção, muito pelo contrário: tornei-me muito mais consciente do que já era! Sinto-me orgulhosa de fazer parte dessa organização, que como diz a palavra, é uma organização mesmo, aqui a gente tem o sarau aos sábados... Uma diferença da vida de fora é que todos aqui se dão, são companheiros, né? Aqui a gente cria uma família, a família é o sem-teto todo! Aconteceu alguma coisa comigo lá fora eles correm para lá. Aqui dentro é civilizado, todo mundo brinca, todo mundo se diverte, sofre também, mas está todo mundo unido. Tem ato? Vamos! A luta é para valer! 
A gente está aqui hoje na casa da Laura porque ela se tornou minha família, e não tenho só ela, tenho a Silvana, a Márcia, o Araketo. Somos uma família.

Em qualquer lugar, em qualquer circunstância da sua vida vai haver dificuldades, mas o legal, o lindo nisso tudo é ter com quem contar e a gente tem os sem-teto. O Movimento nasce daí, de pessoas comuns como eu.

Tenho meu barraco, moro só, mas o fato de morar dentro de um barraco sozinha, não quer dizer que viva sozinha. Se eu tiver de levantar duas horas da manhã para ir a um ato, tenho com quem ir, vai o grupo, vai todo mundo junto porque para a gente ter voz ela tem que ser bem alta. É um absurdo, né? Tanto sacrifício para a gente conquistar um pedaço de terra, mas não importa, o absurdo se fez lindo!

Tenho três irmãos homens do primeiro casamento da minha mãe, que na verdade foi apenas um “juntar-se”. O segundo casamento foi de papel passado, em igreja e tudo, com o meu pai. Esses três filhos dela acabaram ficando com o pai deles. Logo depois de casada minha mãe engravidou da minha irmã, na verdade de gêmeas, mas infelizmente uma das meninas acabou morrendo na bolsa mesmo e nasceu a minha irmã com problema, com desvio mental. Meus pais sofreram muito. Essa minha irmã hoje tem 27 anos. Depois dela veio eu. A vida da minha mãe era uma barra para conseguir cuidar das duas filhas, ela era inexperiente, despreparada, não tinha apoio da família, de nada. Antes de ela nos ter, dormia em rua e tudo. Depois que a gente nasceu arrumou uma casa, alugou, começou a trabalhar de cobradora de ônibus. Quando completei onze meses de vida meu pai, por não aceitar eu ter nascido mulher, me jogou em uma lata de lixo. Quem me salvou e ficou comigo foi minha mãe, e sempre naquela vida: em toda a casa que eles iam morar meu pai fazia bagunça e o dono pedia para a gente sair. Eles ganharam uma casa de presente de casamento, da minha falecida avó, que eu não conheci, mas ele fez minha mãe vender e sobrou apenas um dinheirinho, para eles poderem ficar alugando, então pensa: você está com duas filhas pequenas, uma de colo, uma de mão, você aluga uma casa para morar, seu marido vai lá, bebe, faz aquele fudurço e o dono pede a casa, cansou de dar polícia, cansei de ficar nos braços da minha mãe em Delegacia. Essa vida conheço desde pequena.

Minha mãe não suportou as atitudes de meu pai, tentou empurrar até os meus dois anos, todo mundo da família dele fala isso, mas na hora de culpar, logicamente, a corda arrebenta do lado mais fraco e a culpa pelo fim do casamento cai nas costas dela. Ela me colocou em colégio interno e ficou apenas com minha irmã, que tem problema. Meu pai começou uma perseguição, ela não agüentou e colocou as duas, mas foi combinado com a direção do colégio que ela nos buscaria mais tarde, que nós não estávamos para adoção.

Mamãe sempre nos buscava para passar natal, virada de ano, dia das crianças. Quando podia ela nos buscava. A gente tinha um contato com a nossa mãe, sabia quem era ela. Quase fui 
adotada, ela não deixou. A dona do colégio interno, inclusive, queria adotar a mim e à minha irmã. Lá a gente sofria muitos maus-tratos, eram as maiores cuidando das menores e aconteceu de tudo comigo, inclusive acabei perdendo a audição esquerda, foi triste! Como éramos reprimidas, nem sabíamos como nos abrir com nossa mãe, eu nem sabia o que era apanhar na época. Quando saí de lá conheci meu pai.

Dizem que ainda no tempo de internato ele tentou me roubar, atormentar minha mãe na verdade, mas não lembro disso, nunca vi. Quando ele se separou da minha mãe acabou arrumando outra mulher, teve uma filha com ela e dizem... O que foi realmente comprovado é que ele mexeu com a filha da mulher, de 11 anos. Quando completei dez anos de idade o conheci na porta da escola. Abraçou-me e pediu-me perdão. É estranho você conversar com uma pessoa e não saber por que ela está te pedindo perdão, aí eu perguntei para a família, tudo, fiquei sabendo. Conheço o lado da família dele, mas não posso contar com ninguém, são pessoas que gostam apenas de fazer comentários, não de ajudar, não tenho ninguém para contar.

Agora a minha mãe não, ela sempre foi por nós, mas, a partir do momento que entrei para os sem-teto e falei: “Estou saindo de casa porque não sou obrigada a aturar seu marido”, ela não aceitou! Por isso não me ajuda, se eu quiser sobreviver tenho que trabalhar, trabalho no farol nos finais de semana, já trabalhei de garçonete, mas por ser em Osasco, difícil acesso, perigoso, comecei a ficar apenas no farol. Se Deus quiser vou conseguir emprego em uma padaria de um conhecido meu, aqui perto.

Estudei até o terceiro colegial, ficou faltando três meses para me formar, porque eu faltava demais para resolver problemas e sempre tendo que ir para atos, ir para isso, ir para aquilo, mas não me arrependo porque posso muito bem voltar e ainda conseguir uma bolsa se eu lutar bastante. E lutar para mim é algo que não me causa medo, é uma coisa que faz parte do meu cotidiano e de mim mesma.

Já morei em colégio interno, já morei em muitas casas, mas quando me vi na ocupação, no Valo Velho, no meio de três mil barracos, me apaixonei, me apaixonei de verdade pelo Movimento porque a diferença de estar morando em uma ocupação e ter morado com a minha mãe, ter morado no colégio interno é que no colégio interno a gente apanhava das outras meninas, sofria violência, sofria tudo lá dentro. Eu era largada. Você está morando com meninas de rua, que estão acostumadas a fazer coisas terríveis, e você se vê... Pessoas querendo te adotar porque você é pequenininha, bonitinha, e as crianças não gostavam disso, sentiam inveja, iam lá e batiam em mim! Cresci assim.

Quando fui morar com minha mãe também não a tinha muito do meu lado porque a coitada só trabalhava, só trabalhava. Vai fazer 25 anos de creche. Trabalhava e estudava para poder dar um futuro melhor para a gente, e sempre de aluguel, sempre de aluguel, e ninguém 
para ajudar, só para atrapalhar. Fui crescendo nisso, minha cabeça foi se formando e te falo que é muito difícil, muito perturbador viver como vivi.

Tenho crises de choro, me magôo com qualquer coisa, tenho firmeza com as pessoas, com tudo, mas quer ver eu cair de cama é você falar “isso” para mim. É complicado, as pessoas olham para mim e não acreditam nisso, mas não tem como comprovar a minha verdade, a minha vida, é minha vida, entende? Mas convivo aqui, a diferença é que aqui dentro você acorda, vê um sorriso novo, ouve alguém gritando o seu nome, “oh, to aqui, ta precisando de alguma coisa?” Apesar de não ser como no outro acampamento, que era tudo no coletivo, aqui é cada um no seu barraco, nós somos família ainda, somos amigos ainda. É difícil conviver com 300 pessoas diferentes, mas o diferente é lindo, o que torna tudo perfeito é a imperfeição, o que torna o jogo divertido são as peças que se encaixam de forma inacreditável!

Eu amo tudo isso: amo esse acampamento, amo cada pedaço desse solo e amo essas pessoas, porque cada uma delas é guerreira, é muito guerreira mesmo!

Participei de todos os atos que tiveram depois que entrei, os de Itapecerica foram lindos! Passava a madrugada dançando, gritando, cantando. Passava o ato lá, na madrugada, a gente não podia montar barraco até então, mas era maravilhoso, tomava banho de... Não me acorrentei, só dei uma força. Lá estava a nossa família, se acontecesse alguma coisa com um todo mundo chorava. Se um apanhar vão todos para cima do agressor. Cheguei a entrar na Câmara Municipal uma vez, em um protesto que fizemos, tomei spray de pimenta na cara como todo mundo e não me arrependo, faria tudo de novo porque não é fácil empurrar um acampamento adiante. Sobreviver a tudo isso é um milagre.

Quando estávamos ameaçados de despejo foi choro para todos os lados!Vi uma mulher com aquele monte de filhos, passando a mão nos cabelos e chorando, pensando no que seria dela, olhando aquele acampamento lindo... As correntes no chão, foi essa a visão que tive. Foi muito triste, nossa, quando a vi chorando não agüentei. Ela se perguntava: “o que vai ser agora?” Aí eu pensei: “A gente está unido, não está? Não importa para onde a gente for, com a nossa união iremos longe”. Chorei sim, fiquei tensa sim, corri para um lado, corri para o outro, tentei colocar minhas coisas em um lugar para poder ir trabalhar, porque tinha que ir trabalhar e fiquei muito preocupada com onde a gente iria, como iríamos nos virar. Até mesmo o pessoal que estava correndo atrás de tudo isso para nós, ficou tenso. Foi choradeira para tudo o que é lado, foi péssimo! Mas não perco a esperança de forma nenhuma! Não senti aquilo como uma derrota, não senti nada disso e na mesma hora ali, parada, olhando para aquelas pessoas que teriam a resposta certa para nós, eu vi saindo: “é nosso!”. Dali fui até o ponto para poder ir trabalhar, mas voltei correndo para abraçar todo mundo, a felicidade foi demais! Foi um momento assim: de emoção pura, nunca vou esquecer aquele dia. 
O acampamento João Cândido existe desde o Valo Velho, foi batizado com esse nome lá e a gente pode mudar para o lugar que for que esse nome permanecerá. Graças a Deus não precisamos mais nos mudar, o João Cândido venceu, mas claro que a luta continua para apoiar outras famílias carentes, né? Carentes de atenção, de oportunidade, de amizade, de família, de cultura, de tudo. Acho que a vida é assim: o que sei tenho que ensinar para quem não sabe.

Quando sair minha casa vai ser festa. Vão ser trezentos apartamentos, trezentas festas, uma em cada dia, muitas raves. Depois disso a luta vai continuar sim porque tem muitas outras famílias sem-teto nesse Estado e nesse país.

Hoje temos energia elétrica dentro de nossos barracos e nos viramos com água, com comida, nos viramos para viver. Sobreviver a essa vida não é para qualquer um, para uma pessoa estar aqui e dizer: "Eu quero, eu vou" tem que ser muito otimista, muito determinada e acreditar na verdade, na justiça, na paz, no amor.

Nossa casa vai ser uma vitória linda, um troféu como nunca ninguém jamais teve, e não vai ser um troféu para ficar guardado, vai ser um troféu para ser utilizado pelos nossos filhos, netos, bisnetos, e você pode ter certeza que meu filho vai lutar. Quando tiver um filho ele vai ter que lutar também, vai saber a história do lugar onde vive, como consegui a casa dele. Lá pelos meus 27 anos pretendo ter um filho. Por que não?

Quando sair minha casa, se minha mãe quiser morar comigo e não trouxer o marido, a receberei de bom grado, mas estou pensando mesmo em convidar minha irmã porque a amo demais. Ela é uma pessoa que não incomoda em nada, é especial, mas trabalha, estuda, é muito esforçada e tem mais juízo que eu! Tem 27 anos e nunca teve um namorado.

Como falei, minha oportunidade foi mínima, a minha vida... Tenho crises de choro, mas minha cabeça é feita. Só por Deus mesmo. Amo demais a minha mãe, não odeio o meu pai, mas não criei vínculo com ele, não quero porque nunca precisei dele. Dizem que ele está em Tiradentes, mas não sei e não quero saber, não vai fazer diferença agora. Deus me livre e guarde, mas é uma pessoa que se estiver precisando, mendigando na rua, abro os meus braços, não me importo, porque tudo na vida é uma preparação para você chegar a um ponto mais alto... Mas é doloroso, não agüento ver pais com filhos que eu choro. Não gosto de dia dos pais, não gosto de natal, não gosto de ano novo, mas não é por isso que vou me trancar dentro do meu barraco, me fechar para a vida e para o mundo e falar: “acabou, não quero saber de ninguém nem de nada”. Não! Vou levar o que tenho de melhor às pessoas porque o melhor presente que podemos receber é o sorriso, o abraço, o olhar de carinho e as palavras das pessoas que amamos. Isso não tem dinheiro no mundo que consiga comprar. A dignidade de uma pessoa, a honra, a alegria é tudo do coração e tem que brilhar de dentro para fora. O que vem de fora para dentro é o que você recebe de mais lindo: a amizade. Isso é tudo. 
Tem uma música que me marca muito, que de certa forma fala um pouco de minha personalidade: Garganta, de Ana Carolina. “Minha garganta estranha quando não te vejo, me vem um desejo doido de gritar, minha garganta arranha tinta e azulejos do teu quarto, da cozinha e da sala de estar. Mas não sou beata, me criei na rua e não mudo minha postura só pra te agradar. Aprendi a me virar sozinha e se to te dando linha é pra depois te abandonar. Sei que não sou santa, às vezes vou na cara dura, às vezes ajo com candura só pra te conquistar. Aprendi a me virar sozinha e se to te dando linha é pra depois te abandonar”.

Nunca pensei em ganhar dinheiro cantando. Gosto de cantar para ser feliz e animar as pessoas, dinheiro é uma coisa que prefiro trabalhar e conquistar. Essa música fala um pouco de minha história, porque me criei praticamente na rua, aprendi a me virar sozinha, não consigo ter um relacionamento duradouro, ficar com ninguém, falar: “poxa, estou casada!”, consigo me apaixonar pelo Movimento, pelas pessoas, por um ideal, um objetivo, agora por um homem não garanto não, nem por uma mulher. Sou apaixonada por minha mãe, minhas amigas e pela vida! A vida é uma mulher.

Gosto de me arrumar, de me cuidar. Minha avó deixou um dinheiro na casa da minha mãe para que eu comprasse meu presente de aniversário e comprei dois pares de brincos, um para a minha mãe, porque o aniversário dela passou batido e não tive como dar nada. Os brincos dela ficaram lindos, têm uns detalhes cor de rosa. Ganhei presente da minha mãe e da minha madrinha. Da minha mãe foi um sabonete líquido de morango e da minha madrinha foi dinheiro, aí acabei fazendo uma escova no cabelo.

Sempre vou à casa de minha mãe, mas estou morando aqui, mesmo sem ter minha cozinha. A gente vai fazendo isso, vai fazendo aquilo... Nunca fui boa em guardar dinheiro, nunca fui boa em administrar dinheiro. Vou falar a verdade: sou uma consumista nata! Não paro para pensar. Gosto de comer bem, tomar sorvete, comer pizza, não me preocupo com regime não, porque queimo tudo no ato, na passeata. Quero montar minha cozinha e fazer um almoço para a minha família. Sou uma boa cozinheira. Como tive que me virar desde pequena, sei fazer arroz, feijão, picadinho, assados, bolo, torta, pizza de liquidificador, suflê, saladas, batidas. Tem muita coisa que vou lá e faço, acho uma receita diferente, vou lá e experimento, sou muito de inovar, de inventar, então para mim culinária é isso: é arte.

Eu trabalhava de garçonete, já trabalhei muito de garçonete: a bandeja nessa mão direita e o balde de cerveja na esquerda, a noite toda no salto, mantendo a pose, sem deixar cair um copo! Mentira que já deixei cair sim. Nossa, é difícil, você está a noite toda lá, se equilibrando, cansada, alguém esbarra e você derruba mesmo, mas ninguém leva a mal, porque estão tranqüilos, se divertindo e até onde sei nunca foi descontado do meu salário. Derrubei apenas uma vez, não era desastrada. Toda a pessoa desastrada quando começa a treinar vai vencendo 
pela prática, fica perita naquilo. É que nem cozinhar. Eu era um desastre, meu arroz você podia jogar na parede para rebocar, aí comecei a fazer e agora acho ótimo. Se Deus quiser logo vou ter minha cozinha, estou trabalhando para isso. Tenho que comprar tudo, só estou com um fogão de duas bocas. Quando a cozinha estiver pronta farei uma lasanha para comemorarmos. Acho que já falei tudo. 
Narrativas de uma família de Porto Velho 


\section{Junior}

\section{"Minha intenção maior é conseguir um terreno, construir uma casa para poder constituir minha família.”}

Desde que me entendo por gente procurei ter um objetivo na vida. Meu pai e minha mãe sempre me mostraram isso. Sempre quis fazer uma faculdade de Direito, me formar, ter filhos, casar com a Carol.

Nasci aqui em Porto Velho em 19 de Outubro de 1985, vivi um tempo aqui, um tempo no Ceará, onde meu pai nasceu e um tempo em Ariquemes, acho que uns três, quatro anos. Para o Ceará a gente ia constantemente porque meu pai tinha uma fazenda lá. Ele vivia viajando e às vezes levava a gente, depois trazia de volta. Acho que dos cinco, seis anos estou o tempo todinho aqui em Porto Velho. Meu pai é nordestino, minha mãe é de Porto Velho mesmo, daqui da terra

de Rondônia. É uma rondoniense de muita garra e determinação, nunca nos deixou faltar nada. Meu pai é um cearense "casca grossa”, rígido com as coisas, arretado, afoito com tudo, às vezes ignorante... É muito difícil ele ser paciente com a gente dentro de casa, mas graças a Deus não tive uma adolescência complicada. Minha infância, minha adolescência foram tranqüilas, com muito carinho do pai e da mãe. Eles nunca foram agressivos com a gente, e sempre tentamos conversar para depois agir, não se precipitar e agir de forma errada.

Na minha infância eu fazia estradinha em frente de casa, na areia, e brincava com tampinha de garrafa, fazia corrida de tampinhas de garrafa, brincava de fazer estilingue com liga de pneu para brincar com as tampinhas, brincava com muita coisa, brincava de futebol, de carrinho, de esconde-esconde e aquelas brincadeiras todas da infância. A Patrícia estava sempre junto nas brincadeiras e as meninas da rua também, as meninas e os meninos. Tinha vezes que elas jogavam bola com a gente. Ainda vejo alguns amigos daquela época, cumprimento. Estava viajando para Ariquemes esses dias e encontrei um amigo que mora lá e aqui, porque os pais dele moram aqui...

O início da minha vida escolar foi difícil porque não gostava de ir para a escola. Quando estava fazendo acho que a primeira série, não gostava nem de entrar na sala de aula! Saía, falava para a mamãe que não teve aula. Minha mãe pedia até para a minha irmã me vigiar, porque eu mentia que todo dia não tinha aula para mim. Ela teve que me vigiar lá na porta da sala.

Não gostava porque eu estudava de manhã, não gostava de acordar cedo. Tinha que acordar cedo demais para ir para a aula, depois vinha o sol e me dava vontade de brincar, então eu saia da escola, pegava o ônibus e ia embora para casa. Mas só na primeira série mesmo, porque o restante... Estudei cerca de nove anos no Colégio Rio Branco, do pré-escolar até a sexta 
série. Era uma ótima escola, não sei como está agora. Minha matéria favorita era a Matemática, nunca fui ruim em matemática, me dava bem com os números, agora em Português e Física era meio fraco. Em Química também eu era bom e o restante eu achava tudo fácil, não sentia dificuldade em aprender. Gostava muito de Educação Física! A gente conversava com a professora para fazer torneio entre os turnos da manhã, da tarde e da noite, fazíamos torneio valendo premiação em dinheiro para o primeiro e o segundo lugar, era muito bom e sempre participei.

Saí do colégio Rio Branco na sexta série e fui para o Padre Moretti, concluí meu ensino fundamental e médio lá, no supletivo. Lá a gente também incentivava a professora a fazer torneio valendo dinheiro, premiação e foi lá também que conheci uma pessoa muito especial, a Carolina, minha noiva. Ela estudava na minha sala. Nos conhecemos no terceiro ano, mas ela não dava muito moral para mim não. Foi difícil conseguir namorar com ela, só consegui no outro ano, quando a encontrei no cursinho para o vestibular. Eu estava trabalhando, tive que passar para a noite, antes eu fazia cursinho de tarde. Passei para a turma da noite e a vi, junto com a irmã dela, minha cunhada. Aí fiquei conversando, conversando, conversando e a Nélia, uma amiga nossa deu um toque para ela, falou que eu gostava dela, mas ela disse que eu não tinha iniciativa, era complicado. Até que teve um dia que a gente teve só os dois primeiros tempos de aula, saímos mais cedo e fomos para a casa dela, eu e a Nélia. Ela ia sair com a avó para jantar, mas me chamou em um canto e disse: "Queria falar contigo... Você é um menino legal, um rapaz legal, mas nós vamos ficar só na amizade”. Perguntei: “Você tem certeza?”. Perguntei três vezes, na terceira vez que perguntei e ela respondeu que tinha certeza que ia ser só amizade falei: “Então ta”, mas aí ela me puxou e me deu um beijo. Daí em diante começamos a namorar. Fez três anos e um mês agora dia doze de Maio.

Noivamos em Fevereiro, mas só vamos nos casar mais para frente. Temos que estudar bastante para prestar um concurso, arrumar um emprego. Espero que dê tudo certo. Vamos fazer uma economia, juntar um dinheirinho para poder casar, por isso estamos correndo aí na batalha, atrás de um pedaço de terra, de uma casa para nós, e dando tudo certo, ela terminando a faculdade a gente se casa. Vou estudar também para passar em um concurso, para gente ter nossa casinha, nosso carro, nossa vidinha. Foi por isso que vim para esta ocupação. Minha intenção maior é essa: conseguir um terreno, construir uma casa para poder constituir minha família.

Já vi outras ocupações, mas nunca tinha participado, esta é a primeira vez e espero que dê certo. Meu pai nunca gostou disso, mas veio para tentar segurar um terreno para o meu irmão, que está precisando. Espero que dê tudo certo para gente conseguir construir nossa casa ou então, segurar por um bom tempo e quando valorizar dar de entrada para comprar uma casa em um lugar melhor. Acho que tem muito malandro por aqui, nessa região, não sei se é seguro viver 
aqui, só dá para saber mesmo morando. Onde meus pais moram no inicio também era um pouquinho barra pesada. O nome daquele bairro é Jardim Ipanema, mas no mapa aparece como bairro Igarapé. Não sei por que esse nome, não tem nenhum igarapé - a menos que esteja canalizado - nunca vi nenhum movimento de água. A gente mora naquela casa já tem oito anos, meu pai comprou o lote do advogado dele e construiu, saímos do aluguel. A gente tinha uma vida boa antes, mas meu pai não soube aproveitar. Todo o tempo nas amizades, que nem minha mãe fala: "com as quengas por aí”, amizade, amizade, amizade e foi se acabando o dinheiro, ele não soube segurar e acabou torrando tudo. A gente morava no centro, perto do Rio Shopping, na Getúlio Vargas, tivemos que vender nossa casa, fomos para o Ceará, ficamos um tempo lá, acho que uns dois anos e depois voltamos porque minha mãe não quis ficar. Depois disso daí vivemos só pagando aluguel, pagando aluguel, até que ele conseguiu comprar aquele terreno e construir.

Gosto da casa dos meus pais e daquele lugar, não acho ruim não, mas não tenho muita amizade, não conheço quase ninguém, conheço só o pessoal da rua, a Nélia, que é amiga desde a infância, algum vizinho que vai até nossa casa pedir alguma coisa ou contratar algum serviço do meu pai. Ele é técnico de refrigeração, faz manutenção em ar condicionado, freezer, central de ar, geladeira, balcão, frigorífico.

Gosto também desta cidade, Porto Velho, que agora está crescendo, se desenvolvendo e vai proporcionar bastante emprego para algumas pessoas com essas hidrelétricas de Furnas e essa construção de shoppings. Nela há dois lugares que para mim são especiais: a Estrada de Ferro Madeira-Mamoré e a Praça Aluízio Ferreira, a praça da pista de skate. Tenho boas lembranças desses lugares e eles continuam presentes em minha vida, pois são os lugares onde passeio com a Carol. A gente fica na beira do rio tomando água de coco, conversando com o pessoal.

Porto Velho é bom para se morar, para educar, porque aqui tem ótimas escolas, mas na parte da habitação e da saúde não está boa não, tem que dar uma melhorada grande. Se for depender da saúde pública muitas vezes a pessoa morre e nem sabe por que, como foi o caso de um amigo do meu pai, que morreu e ninguém soube a causa. Ficou internado no CEMETRON e morreu. Estava tendo ataques de epilepsia aí uns dois dias antes de morrer, caiu, bateu a cabeça no chão e não teve ninguém para socorrê-lo, nem um enfermeiro, nem nada. Somente no outro dia, quando meu pai foi visitá-lo viu que tinha uma poça de sangue no chão e que ele tinha quebrado a cabeça. Nenhum enfermeiro, nenhum médico viu isso antes! É um estado crítico. Fico pensando... Até questionei com o meu pai. Antes de esse amigo nosso morrer... Ele era amigão, trabalhava junto com meu pai e sempre pedia para ele ficar perto dele, gostava que só do meu pai, aí no dia que meu pai foi visitá-lo ele estava caído no chão, com uma poça de sangue ao redor. 
A Educação aqui não está ruim, mas a Saúde está péssima. Me preocupo com a saúde, porque a parte da família da minha mãe é cardíaca, do meu pai eu não sei, nunca teve nada hereditário agora da minha mãe: meu avô morreu do coração, minha avó morreu do coração, a maioria morre de ataque cardíaco. Por parte do meu pai tenho só um tio que morreu de câncer, mas também porque ele mexia muito com veneno, tinha uma fazenda em Ariquemes, passava veneno e não usava nenhum tipo de proteção, passava sem máscara, sem nada. Todo mundo fala que deve ter sido por causa do veneno que ele passava nas plantas.

Com relação a esta luta por moradia, acho que o pessoal que está aqui realmente precisa de casa. Pelo menos aparentemente todos precisam. Se você olhar, é um estado de necessidade mesmo, estava conversando com uns aqui... Uns moram na casa da sogra, outros moram na casa da mãe ainda, com mulher e filhos, uns pagam aluguel, outros estão desempregados, então se esse acampamento vigorar, se os lotes forem legalizados e vier pelo menos um auxílio para a construção de casas populares vai ser ótimo. Em vez de pagar aluguel essas pessoas vão construir algo que é de fato delas. Acho que para se resolver essa situação de extrema desigualdade social, que se reflete no problema da habitação, tem que ter uma atitude do governo, mas também a organização do povo para reivindicar seus direitos. Tem muito sem teto, tem muita gente pagando aluguel, morando em área de risco, em zona ribeirinha, nas ruas, na beira das estradas, debaixo dos viadutos, em barracos e tem muito terreno que nem este: desocupado, baldio, que poderia abrigar essas pessoas.

Tem que vir uma atitude do governo, da Prefeitura, para tirar essas pessoas desse estado, que é muito crítico. Tem muitas pessoas morando mal e tem muito espaço que os ditos donos não ocupam e não deixam ninguém ocupar. Acho que essas terras deveriam ser doadas ou financiadas para a gente pagar conforme pode, a fim de termos um teto. Às vezes a terra está parada há muitos anos, o pessoal vai, invade, limpa, constrói, depois de construído o dono do terreno vai lá e destrói tudo, manda passar o trator, e as pessoas ficam ao deus dará de novo.

Este terreno de 10 metros de frente por 25 de fundo significa para mim a possibilidade de um lar, um lar onde eu possa morar com minha mulher, criar meus filhos, onde possa descansar depois de um dia de trabalho. Seria uma superação para mim, uma vitória. Se conseguirmos não terá sido sem esforço, sem trabalho, porque tem o esforço de estar aqui todos os dias, limpando, roçando, matando cobra, correndo atrás de madeira para construir o barraco. Por enquanto só podemos construir de madeira, porque se construirmos de alvenaria e vier ordem de despejo a gente vai perder todo o material.

Felizmente tenho o apoio da minha família para estar aqui. Minha família é constituída por pai, mãe e três irmãos, na realidade quatro: uma irmã fora do casamento, só por parte de pai. São dois rapazes e uma moça, porque com essa outra irmã nós não temos contato. O William é o 
mais velho, depois vem a Patrícia, em seguida essa minha irmã por parte de pai, o Luciano e por último eu. Sou o caçula. Minha irmã fora do casamento tem quase a mesma idade da Patrícia e se chama Messiane. A gente não tem contato com ela, mas sei que já foi casada e acho que agora está separada. Messiane porque o nome do meu pai é Manoel Messias. O nome da minha mãe é Odália. Ela faz bolos, tortas, faz tudo, mas a profissão dela é manicure, pedicure, depilação e arrisca também esses negócios de pintura, corte de cabelo... Mas o talento maior dela está na culinária, ela é uma cozinheira de mão cheia, cozinha muito bem!

Gosto de comer de tudo, tudo o que minha mãe faz para mim está bom, só tem uma coisa que não gosto: jiló, jiló eu odeio! Do que mais gosto é do bolo de chocolate que ela faz, da surpresa de morango, do empadão, da torta de frango. Tem várias coisas que ela faz que são deliciosas, como pudim vaporoso de ameixa, que é muito bom! Gosto de doces e de salgados, mas prefiro que venham primeiro os doces. Não sou tão bom como minha mãe, mas arrisco cozinhar um pouco. Sei fazer arroz, feijão, carne, frango, omelete. O prato que mais gosto de fazer é omelete, bem preparado, com bastante cebola. Da última vez que fiz coloquei sardinha, cortei salsicha, misturei bem e ficou ótimo. 


\section{Carla}

“Meu pai foi um guerreiro!”

Venho de uma família de dez irmãos, sou filha de pai nordestino e mãe mato-grossense. Meu pai veio para cá na época da Segunda Guerra Mundial, em 1945, porque os nordestinos que não quisessem ir para a guerra tinham que vir para a Amazônia cortar seringa.

As histórias que meu pai contava nos marcaram muito - a mim e a meus irmãos - porque ele contava e se emocionava. Ele e os amigos, as pessoas que vieram com ele, de navio, do Nordeste para cá vieram em busca de um sonho, mas este sonho foi ficando pelo meio do caminho. Meu pai dizia que a maior tristeza dele era ver os amigos morrendo pouco a pouco chegou a ter 35 pessoas mortas por dia nessa viagem para a Amazônia, e quando chegaram a essa terra, que foram trabalhar nos seringais, morriam mais de cem homens por dia, vítimas de malária, hepatite, picada de cobra. O Estado trazia as pessoas como trazia animais, sem a menor condição de vida. Isso faz a gente lembrar do sacrifício das pessoas, dos desbravadores que vieram em busca de sonhos, em busca de uma terra prometida, de riquezas, para um dia poder buscar a família. Sonhos que foram interrompidos, talvez por falta de conhecimento, de ajuda dos governantes.

Percebo que as pessoas que vieram na época da Segunda Guerra, vieram praticamente como escravas, porque morreram sem direito a nada, sem direito a sequer um funeral digno. Morte injusta diante de todo o esforço que fizeram. Os mortos eram enrolados em lençóis e enterrados na beira das estradas ou na margem dos rios. A gente cresceu vendo isso.

Daquela época para cá muitas coisas mudaram, mas ainda existem muitas restrições de direitos. Muitos direitos e necessidades não são respeitados, como o direito/necessidade de ter um lar, uma casa, um emprego e isso acaba refletindo negativamente na sociedade. Por falta de um lar para morar, por falta de um emprego, o índice de marginalização tem crescido cada vez mais, e como conseqüência disso, a violência. Em se tratando desta matéria, a gente observa que pouca coisa mudou, não houve muita diferença. A única diferença é que hoje as coisas se tornaram mais fáceis, mais acessíveis por conta do desenvolvimento. Hoje temos estradas, transporte mais fácil, acesso à cidade, enquanto antigamente não, e por causa disso muitos morriam à míngua no meio do caminho, por falta de assistência médica, de medicação.

Meu pai contava muitas histórias, ficcionais e verdadeiras, e foram esses momentos de ouvir as histórias narradas por ele que mais me marcaram.

Penso que meu pai foi um guerreiro vencedor, por ter conseguido superar todas as barreiras, ter conseguido construir família e formar os filhos, mas não conseguiu usufruir as 
conquistas dessa batalha. Quando chegou o momento de ele usufruir de toda essa luta, aos seus 64 anos de idade, vieram as conseqüências da batalha. Meu pai faleceu em 1990, em conseqüência das doenças tropicais que contraiu. Conseguiu sobreviver por muito tempo, mas na velhice essas marcas “de guerra” apareceram: de tanta malária que pegou terminou desenvolvendo uma cirrose fatal.

O encontro de meu pai com minha mãe é uma coisa engraçada. Quando meu pai chegou a Rondônia, ainda nem era Estado, era Território Federal e tudo o que havia eram seringais. Não tinha polícia, mas alguns anos depois, em 1949, se não me falha a memória, foi criada a Guarda Territorial, onde muitos desses arigós foram recrutados para compô-la. Meu pai foi um deles. Ele foi destacado para uma localidade chamada Tabajara, descendo o Rio Machado, onde hoje é a cidade de Ji-paraná. Descendo o rio nesse barco, conheceu minha mãe. Ele, solteiro, ela, separada do primeiro marido. Simpatizaram-se e na conversa ele perguntou se ela queria morar com ele. Ela foi, viveram juntos por 35 anos, até que a morte os separou. Tiveram dez filhos. Acho uma história muito bonita porque é muito difícil hoje em dia você manter um relacionamento de 35 anos dessa forma. As pessoas hoje em dia se "conhecem”, namoram, se casam - se "conhecem” antes de casar - e muitas vezes o relacionamento não dá certo. O deles deu certo, talvez por carência, porque estavam longe da família, da terra natal. Talvez isso tenha contribuído para que o casamento deles durasse tanto tempo.

A história de como meu pai chegou, de como conheceu minha mãe e de como construíram juntos uma família são coisas que marcaram minha história de vida. Vejo os dois como guerreiros que batalharam e conseguiram vencer, agora ele, infelizmente, não conseguiu desfrutar as coisas que construiu, mas deixou para alguém, para os filhos, para a esposa.

Minha vida em família, minha convivência com os irmãos posso dizer que foi muito boa, porque antigamente os pais tinham outra maneira de educar os filhos e estes, sabiam respeitá-los. Antigamente bastava um olhar dos pais para os filhos entenderem o que estavam querendo falar. Era bem legal porque não existia ciúme entre irmãos, não existia intriga entre irmãos. Apesar de todo o sacrifício e dificuldades financeiras da época, conseguíamos nos relacionar bem. Todos sabiam partilhar. Partilhavam roupas, alimentos, coisa que a gente não vê hoje em dia, talvez até por causa do progresso... Hoje está tudo muito avançado... Antes a mãe ficava em casa, era dona de casa, seu trabalho era cuidar dos filhos e do lar. Hoje os pais deixam seus filhos na mão de terceiros, e por este motivo, acho que fica faltando um pouco daquele amor paternal, maternal, que os filhos tanto precisam. Muitos pais têm substituído o amor e o cuidado por coisas materiais, tentando suprir essa falta de reunião da família, de comunicação, de diálogo.

Antigamente as famílias se reuniam, sentavam, conversavam. Não tinha televisão. Hoje, devido ao desenvolvimento as coisas ficaram bem diferentes. 
Lembro de coisas que a gente não vê mais, como festas juninas, reuniões de família. No meu tempo de menina as famílias se reuniam, chamavam os vizinhos e em época de festa junina faziam fogueira, contribuíam uns com os outros para fazer a festa. Era um lazer! Festas natalinas eram a mesma coisa, aconteciam do mesmo modo, e hoje está diferente. As pessoas não valorizam mais essas datas comemorativas. Hoje, se você quer participar de uma festa junina tem que ir aos arraiais de comunidades religiosas, empresas, instituições, mas nesses arraiais há competição e aglomeração de estranhos, não existe mais aquela coisa familiar. O mesmo ocorre com as festas de final de ano, as festas natalinas. Antigamente toda a família se reunia, comemorava-se em família, hoje não, pois chega essa época e as pessoas se preparam para ir aos clubes, se esquecem da confraternização e do que significa aquilo.

Nessas festas aqui em Porto Velho a gente comia coisas da região. Mingau de milho, que lá para o Sul chamam de canjica, aqui chamamos de "mingau de milho ou mungunzá". Comíamos macaxeira, milho assado na fogueira, banana assada na fogueira, batata doce, esse tipo de coisas. No Natal comíamos o tradicional vatapá, maionese, arroz e galinha assada, que não poderia faltar. O Natal, hoje em dia está mais sofisticado, com comidas de luxo, coisas que a gente não vê na mesa das pessoas humildes. Aí é quando esse tipo de festa perde a essência, perde o significado, porque se vê tanta coisa na mesa de quem tem poder, e na mesa de quem não o tem muitas vezes não há sequer o que comer. Conheço casos de amigas minhas que na época do Natal não tinham o que comer, enquanto na casa ao lado estava tento festa, muita comida, bebida. Estavam festejando o Natal, mas perdeu-se a essência quando você esqueceu que seu amigo do lado não tem o que comer. Você está festejando o Natal hoje, comendo, bebendo, mas está esquecendo que do teu lado tem alguém que não tem nem o que comer. E que adianta comemorar desta forma? Será que se tira proveito disso? Não sei.

Em dias normais gosto de comer muita besteira. Penso que essas coisas que tanto gosto de comer hoje, gosto porque foram coisas que não pude comer na infância. Como hoje eu trabalho, tenho condições de comprar, me alimento disso, mas na minha infância muitas vezes a gente tinha vontade de comer um bolo, de comer um biscoito recheado, chocolate, refrigerante, e não tpodíamos, porque não tínhamos condição financeira. Hoje, em termos de alimentação - vou ser bem sincera - não sou chegada a comer comidas salgadas, carnes, frango como muito pouco, gosto de frutas. De frutas continuo gostando, talvez porque na minha infância, por ter vivido nessa região amazônica, tinha muitas frutas. Em cada quintal tinha um pé de manga, de banana, de laranja, e assim por diante. A gente tinha o costume de comer fruta, mas as outras coisas eram meio difícil, porque tinha que comprar. Então, hoje, adoro chocolate, biscoito, refrigerante, bolo, talvez porque tenham me faltado na infância, e isso fica no subconsciente da gente. Não sei, penso eu que sim. 
Falei que hoje trabalho e posso comprar as coisas que gosto de comer, mas falta falar um pouco sobre o meu ofício. Trabalho como orientadora educacional, tenho graduação em Pedagogia, pós-graduação em Atuação Profissional na Escola, que abrange as áreas: administração, orientação e supervisão. Essa foi uma pós que paguei para fazer, mas fiz também uma gratuita, em Gestão Escolar, concedida pelo Governo Federal, que também abrange essas três áreas, e agora estou fazendo uma particular, em Libras. Por que a pós em Libras? Porque trabalho em uma instituição que atende estudantes surdos, é uma escola que tem surdos inclusos, mas é muito carente. Uma escola de Ensino Fundamental, de primeira a oitava série, que atende alunos ouvintes e não-ouvintes e tem apenas três intérpretes, é difícil.

A gente sabe que até os "normais” têm problemas de aprendizagem, quanto mais eles, que não ouvem e não falam. Esses alunos surdos são muito estressados, então acontecem muitos problemas na escola, e muitas vezes era preciso interromper a aula para que o intérprete pudesse interpretar os problemas corriqueiros do dia, que aconteciam no ambiente escolar, mas fora da sala de aula. O professor continuava ministrando sua aula, os alunos ouvintes continuavam aprendendo, e os surdos ficavam prejudicados. Observei então a necessidade de aprender a língua. Aprendi, gosto de trabalhar com eles, amo trabalhar com eles e por conta disso estou fazendo essa especialização. Meu objetivo, quando me aposentar, daqui a cinco anos, é trabalhar voluntariamente com eles. Trabalho, desta forma, no setor específico de orientação educacional para surdos.

É muito triste porque até dentro da escola há preconceito. O setor pedagógico que trabalha com Ensino Especial tem pouco apoio da administração escolar, porque o surdo é visto como uma pessoa deficiente, e ele não é deficiente, apenas não fala porque não escuta, mas é uma pessoa normal: pensa, raciocina, sente, sabe o que é bom, o que é ruim, mas a gente encontra muita dificuldade dentro da escola. Às vezes a gente quer fazer um trabalho de valorização, mas não tem apoio. Os projetos que conseguimos desenvolver são feitos mediante parcerias. Algumas vezes a gente encontra apoio na SEDUC, outras não, por questões financeiras, e a gente sabe que um projeto requer recursos financeiros. Ano passado montamos um projeto de ensino de língua de sinais para atender pessoas interessadas e até mesmo para atender a família dos surdos, porque é primordial que a família tenha conhecimento da língua, para saber lidar com as situações. Projetamos um curso de um ano, a ser ministrado pela Coordenação Pedagógica do Ensino Especial, que teve a professora Cecília e eu como orientadoras e autoras do projeto. Esse projeto funcionou muito bem dentro da escola, com certificação e tudo, teve bom aproveitamento. Mães que não sabiam Libras hoje se comunicam com seus filhos, conseguem expressar suas ansiedades, seus desejos. Quisemos esse ano continuar com esse curso, mas fomos interrompidos porque a SEDUC alegou que não recebeu o 
projeto, e, portanto, que ele não pode ser desenvolvido. Se é um projeto feito pela escola, para ser desenvolvido dentro dela, envolvendo funcionários que compõem seu quadro, e que tiveram eles mesmos que colocar a mão no bolso para custear esse projeto, comprar todo o material de papelaria, tirar fotocópias das apostilas, sem receber nenhuma contribuição do Governo, porque teríamos que comunicar a SEDUC? Muitas vezes a comunicamos sobre várias coisas, apresentamos várias iniciativas e não tivemos apoio.

Segundo a SEDUC houve uma denúncia de que o curso aconteceu durante um ano sem ela ter sido comunicada, e por causa disso o projeto está parado. Tem várias inscrições já feitas, inclusive de acadêmicos da área de Pedagogia, e estamos esperando a liberação para poder dar continuidade, agora a gente acha muito triste batalhar por uma coisa, elevar o nome da escola e outro ficar com o mérito. O projeto não é da Secretaria de Educação, é da escola. Estamos esperando a liberação, mas se não vier vamos buscar parceria fora e fazer com que o curso funcione fora do ambiente escolar, fora dessa comunidade.

Como projeto pessoal, tenho vontade de fazer um curso de Direito, me especializar na área para defender os direitos da mulher, as causas da mulher. A mulher tem muitas necessidades... Muitas vezes é mal-interpretada, mal-recebida, mal-vista, desvalorizada, violentada, então quero fazer Direito para trabalhar nestas causas.

Me envolvi em um outro projeto, que é simultaneamente familiar e político: a ocupação Chico Mendes. Comecei a participar daquela ocupação e contribuir da maneira que me era possível: motivando as pessoas, entrando em contato com advogados, elaborando cadastros. Fiz isso porque vi a necessidade daquelas pessoas de terem um lar, terem um teto. Há pessoas que realmente necessitam e há aquelas que estão lá para tirar proveito. Tem pessoas que tomam a frente porque querem realmente ajudar, e tem aquelas que tomam a frente para tirar proveito em benefício próprio, foi isso que observei na associação Chico Mendes. Havia ali uma disputa de poder, as lideranças não estavam preocupadas com as pessoas necessitadas, mas sim com questões de autonomia, poder, autoridade, querendo ver quem manda mais, e isso acabou prejudicando o trabalho, a luta social por moradia. O que mais percebi lá foram pessoas da liderança com interesses político-partidários, tentando se promover, fazendo campanha eleitoral. Embora elas fizessem de tudo para não deixar isso transparecer, nas entrelinhas foi isso que observei, tanto que a comunidade Chico Mendes não foi para frente. Não foi para frente porque não houve interesse das pessoas que estavam à frente de buscar o bem-estar do outro, buscar satisfazer as reais necessidades do outro. Houve interesse apenas de satisfazer os interesses próprios, de se beneficiar. 


\section{Carolina}

\section{“Sou do tipo que não mexe com ninguém, mas não venha mexer comigo, entendeu?"}

Não recordo muita coisa da minha infância, mas minha mãe me contou que alguns meses antes de eu nascer peguei catapora. A barriga dela ficou cheia de bolhas. Conforme fui crescendo vi que as crianças de minha convivência pegavam catapora e eu, apesar de ter contato com elas, nunca pegava, aí perguntei para minha mãe o porquê e ela explicou que eu já tinha pego quando estava na barriga dela. Vai saber, né? Minha infância foi bacana, não foi infância de criança triste, sofrida. Meu irmão e eu vivíamos 24 horas na rua empinando papagaio e jogando peteca. Para estudar era um sacrifício, minha mãe tinha que chegar do trabalho e correr atrás da gente, colocar a gente para dentro de casa para tomar banho e ir para a escola. Muitas vezes eu inventava que estava com dor de cabeça ou então, quando ela ligava para saber se a gente tinha ido eu dizia que estava chovendo, e ia brincar.

Minha mãe ia trabalhar e deixava a gente sozinha. Uma vez levamos uma pisa porque quando ela chegou a vizinha contou que a gente estava com um monte de papel, tacando fogo na área da frente de casa. A casa era de madeira.

Meu irmão tinha a maior raiva de mim porque ele já era homenzinho, queria estar com os colegas, conversando, mas eu vivia atrás dele, não deixava. Às vezes ele me expulsava, mas eu não tinha vergonha e logo ia atrás dele de novo. Apesar disso, sempre me dei melhor com ele do que com minha irmã.

Na minha infância tive duas casas e duas mães e até hoje chamo minha avó materna de mamãe. Recordo que meu pai saía para trabalhar seis horas da manhã, nos acordava, muitas vezes nos colocava ainda dormindo dentro do carro e largava a gente na casa da mamãe. Aqui a gente tomava café, almoçava, daqui ia para a escola, da escola vinha para cá de novo, e só de madrugada, umas três horas da manhã que meu pai buscava a gente e levava para casa. Fomos criados mais na casa da minha avó do que na nossa casa, que servia apenas para dormir e brincar.

A casa da minha avó sempre foi cheia de gente, sempre teve muita comida, muita festa, muita briga. Éramos pequenos e levávamos muita bronca de tio, não gostávamos, ficávamos chateados, com raiva. Lembro que uma vez meu tio Francisco veio para cá e trouxe a família: a filha, o filho e a mulher. Eu tinha uns doze anos, a filha dele também tinha mais ou menos a minha idade, e não sei por que começamos a brigar. Ela era filha adotiva, mas ainda não sabia e eu, com raiva, acabei contando. Discuti, a chamei de palhaça, alguma coisa assim... Ela disse que quebrava meu dedo: “Uma vez eu quebrei o dedo de um menino lá na escola porque ele me 
chamou de palhaça, me chama de palhaça para ver!” Contei que ela era adotiva, que não sei o que lá. Eu estava sentada à mesa e o pai dela me puxou, abaixei a cabeça, e ele disse: “A próxima vez que eu te pegar falando besteira eu corto a sua língua!” Os dois filhos eram adotivos, ele tinha criado desde bebezinhos, como se fossem filhos legítimos. Dei a notícia da pior maneira possível, mas acho que ela não levou muito em consideração não, porque ele foi conversar com ela e só depois, aos poucos foi que ela foi saber mesmo.

Segui meus estudos vivendo na casa da minha avó, indo para casa dos meus pais só para dormir. Até a oitava série estudei no Carmela Dutra, uma escola tradicional daqui de Porto Velho, antigamente uma escola só para meninas. Saí de lá por causa da idade. Acho que estava com dezesseis anos ainda na oitava série. Fui estudar no Padre Moretti, só que era muito distante da casa dos meus pais, então vim morar de vez aqui na casa da mamãe. Essa escola era supletiva, você fazia uma série em um semestre. Foi nela que conheci o Junior, mas a história vocês já sabem, ele já contou na entrevista dele.

Terminei os estudos e continuei morando com a mamãe. Iniciei a faculdade. Quando estava no segundo período da faculdade fui embora, por causa de desavenças, de brigas, porque sou assim: se eu não falo com uma pessoa dentro de um ambiente, prefiro não ficar ali. Tem pessoas que não se incomodam, mas eu me incomodo. Voltei para a casa de minha mãe, aí lá de novo desavenças, e acabei retornando para cá. Continuo fazendo minha faculdade, batalhando para vencer na vida, estudando, porque tenho a meta de passar em um concurso e quem sabe, depois disso, casar e ter filhos.

Quero ter minha própria casa para não ter que ficar de um lado para o outro. Por mais que seja sua mãe, sua avó, você não é mais criança, já sabe o que quer para sua vida e não se sente à vontade em estar dependendo das pessoas. Por mais que não joguem nada na sua cara, é ruim, você prefere ter as suas coisinhas independentes. Até chegar lá a gente vai levando a vida da maneira que é possível. Por causa desse desejo de ter minha casa, fui participar da ocupação Chico Mendes. Nunca tinha me imaginado fazendo isso e conheci a ocupação meio que por acaso. Um amigo do Junior, meu noivo, que trabalha com ele estava passeando com a esposa por aquela região, viu a ocupação, parou e perguntou aí o pessoal falou que era uma invasão, que tinham acabado de fazer aquela invasão. Ele foi até a casa do Junior e o avisou. O Junior falou para mim e fomos para lá. Ele pegou terreno para ele, para o pai dele e para o irmão, que está em prisão condicional. Depois de uma semana falei para o pessoal daqui de casa e para outras pessoas que conheço. Todo mundo quer um pedacinho de terra para morar.

Fiquei três meses direto lá na ocupação, agora estou meio afastada por causa dos estudos e porque estou morando longe, sem transporte. Estou estudando à tarde e à noite, não estou mais lá todo o tempo, então não sei como está a negociação daquelas terras, nem sei se vai 
vingar. A torcida é para vingar, para dar certo, agora não sei. Deus queira que sim, porque estou na expectativa. Mas não basta ganharmos o terreno, precisamos de um auxílio para construir as moradias. A questão não é querer morar ali, é ter condições para construir. Como estou desempregada, para mim é difícil, então estou pensando se seguro o terreno até ter condições de construir ou se vou doar para outro, passar para frente, porque é melhor passar para uma pessoa conhecida do que perder. Já que não estou em condições de estar ali no momento acho que talvez seja melhor passar para alguém que esteja precisando mais do que eu, e que tenha condições de fazer logo um barraco. Não tenho como comprar material de construção.

Enquanto não se resolve a vida da ocupação, continuo meus estudos, porque não posso reprovar em nenhuma disciplina. É ralado você ter que pagar faculdade todo mês e ainda ter que pagar matéria. Tenho que me desdobrar para não reprovar em nenhuma. Faço faculdade de Processamento de Dados, estou no terceiro período, no final do ano que vem termino. É um curso que estou gostando, apesar de não ter aprendido muita coisa ainda. Você só vê teoria, não aprende na prática. Escolhi esse curso por que hoje em dia, para você trabalhar em qualquer lugar que seja do mundo, tem que ter uma noção de informática. Se não souber como vai trabalhar nesse sistema? Não é preciso ser formado em Informática para ter um computador em casa, ou acessar a internet, você pode fazer isso de uma lan house. Hoje muita gente tem a oportunidade de contar com essas tecnologias, é uma coisa que está se popularizando, mas quando se trata de inserção no mercado de trabalho, é preciso saber mais do que o básico.

Outra coisa importante da minha vida que gostaria de contar é sobre meu noivado com o Junior. Esse momento eu considero muito especial porque depois de três anos de namoro eu adoeci, me internaram, estive muito mal mesmo e o Junior comprou nossas alianças. Quando saí do hospital, que fui para casa, ele aproveitou a oportunidade que meu pai estava lá e conversou com ele. Meu pai ficou pensativo, falou umas coisas para a gente, deu uns conselhos e ficamos noivos, mas ainda não conseguimos nos casar porque não temos emprego nem casa. A felicidade nunca é completa, nem tudo é um mar de rosas, tem que saber levar, tirar proveito de tudo, separar as coisas boas das ruins e seguir a diante.

Com minha família nunca tive problemas, mas é claro que é normal acontecerem algumas desavenças de vez em quando, um falar uma coisa, você não gostar. Isso já me aconteceu, mas nada de brigar com alguém e ficar sem se falar o resto da vida. Já tive desavença com uma tia minha, a gente ficou um tempo sem se falar, depois voltamos. Com um tio meu também, porque ele é agressivo, falava as coisas para as pessoas sem pensar, agredia, ofendia, mas a pessoa com quem fiquei mais tempo sem falar foi um outro tio meu. Foi na época em que a mamãe recebia a pensão do papai integral, sozinha, e viajava bastante, curtia a vida, mas sempre com muita responsabilidade e tudo o que as minhas tias queriam ela comprava. Quando o 
papai faleceu ficaram duas tias minhas menores de idade, a Andréa e a Adriana, por isso elas tinham direito à pensão. A mamãe fazia tudo o que elas queriam, comprava tudo o que elas queriam, até para os namorados delas era tudo do bom e do melhor, mas num belo tempo elas começaram a achar que não estava bom, conversaram com esse meu tio, não sei se ele fez a cabeça delas... Só sei que quando a mamãe chegou a confusão já estava armada. Ela estava viajando para o Nordeste nesta época. Elas se juntaram e falaram que a mamãe estava gastando a pensão delas toda, que estava só passeando,viajando e elas aqui só chupando dedo, falaram isso na frente da minha mãe, junto com esse meu tio, e ele só incentivando elas a desmembrarem a pensão, aí minha mãe foi defender a mãe dela, dizer que elas estavam sendo injustas porque sempre tiveram tudo do bom e do melhor.

A mamãe nunca negou nada para elas, se queriam fazer curso, faziam, se queriam viajar, viajavam, levavam dinheiro, tudo o que elas queriam comprar de presente para os namorados elas compravam, presentes caros, roupas de marca, mas para elas não estava bom, e em vez de chegarem para mamãe e pedir para desmembrar ficaram falando que ela estava só torrando o dinheiro.

Quando a mamãe chegou minha mãe contou para ela. Aí se voltaram contra a minha mãe, ficaram com raiva. A Andréa chegou até a xingá-la e fechar a porta na cara dela, pararam de falar com ela. Minha mãe ficava do lado de fora, chorando e a gente já era adolescente, já entendia melhor as coisas e qual filho gosta de ver as pessoas humilhando sua mãe, destratando, desfazendo da sua mãe? Tomei sim as dores dela porque via seu sofrimento, via ela todo o tempo chorando, via baterem a porta na cara dela, jogarem coisas sobre ela. Esse meu tio, quando passava por ela cuspia no chão e se ela chegasse, saía, dizia que estava fedendo, que estava podre, coisas desse tipo assim, aí eu fiquei chateada e passei a não falar mais com ele. A mamãe chamava a atenção dele, mas não resolvia.

Muitas vezes me meti, falei para ele se colocar no lugar e que antes de ele vir gritar com ela que fosse ter moral dentro da casa dele, com a família dele, porque ele não tinha moral com nenhum dos filhos e queria ter moral com a gente, gritar com a gente. Isso eu não admitia! Fiquei uns cinco anos sem falar com ele, só voltei a falar a uns dois anos atrás. Antes a gente convivia bastante, ia a festas, comprava roupas da esposa dele. Aos pouquinhos a gente foi voltando, freqüentando a casa deles, esquecendo o que passou e hoje conversamos normalmente. Não estou falando isso para acusar os meus parentes, denegrir a imagem deles, mas para ressaltar a situação e esclarecer porque a gente ficou sem se falar. Não quero que leiam e achem que estou falando mal deles.

Problema com família assim acho que só foi esse, agora lá de casa, dos três irmãos, quem sempre se deu bem foi eu e o Caio, desde pequeninho o Caio não se dava bem com a 
Camila, eu não me dava bem com a Camila, mas a gente ia se aturando. Agora mesmo estamos brigadas porque ela estava querendo me sacanear, falando mal de mim para minha mãe, mas sobre essas coisas é melhor a gente nem entrar em detalhe, para depois não gerar confusão. Nem comento mais, deixo para lá. Sou do tipo assim que não mexe com ninguém, mas não venha mexer comigo, entendeu? Relevo muita coisa, tolero muita coisa, às vezes o pessoal fala piadinha, eu não gosto, mas fico na minha. Vou fazer confusão por causa disso? Agora quando vejo que está demais tento colocar a pessoa no lugar dela, mas como algumas pessoas aqui de casa não sabem conversar, são muito ignorantes, você não pode falar nada que já gera uma briga. Só elas podem falar, mas se você falar qualquer coisa para elas, não aceitam. É assim que funciona.

Percebo uma relação de poder, de autoridade nisso tudo. Você vive em um ambiente, às vezes tem vontade de falar as coisas e não pode, você agüenta tudo calada para evitar confusão porque aqui na mamãe, por mais que os filhos dela estejam errados, são filhos dela, entendeu? Ela jamais vai ir contra eles, ficar imparcial, ver quem está certo e quem está errado. Sempre esteve na defensiva dos filhos, então, se vejo que alguma coisa está errada, se alguém faz uma piada para mim ou fala alguma coisa, prefiro tirar por menos e ficar calada porque se eu for fazer a minha defensiva vou ficar como se eu tivesse gerado a confusão, como se eu fosse encrenqueira. Prefiro não falar nada.

Sei que as coisas mudam, mas não quero, quando eu crescer na vida, jogar na cara tudo o que fizeram comigo. No dia que eu vencer na vida jamais vou fazer o que eles fazem hoje, vou apenas mudar de situação. Não vou virar a cara para ninguém só porque estou bem, não vou deixar de falar com a minha família nem jogar na cara o que fizeram comigo no passado, que até hoje não esqueci, porque às vezes você não esquece... Tem algumas coisas que você deixa para lá se você não for do tipo de ficar jogando na cara... Eu guardo para mim, não falo nada. Às vezes as pessoas jogam na sua cara alguma coisa, mas eu não tenho coragem de falar nada, sou assim: guardo porque sei que não vai valer a pena falar, só irei me rebaixar mais. Prefiro me redimir e entregar para Deus.

Penso em constituir família, ter minha casa e uma vida boa aqui em Porto Velho mesmo. Sou índia, nunca saí daqui, só conheço Porto Velho e alguns de seus distritos, então não tenho uma cidade preferida. Ao contrário de meus irmãos, nunca viajei, não conheço nenhuma metrópole. Sou a índia da Amazônia.

Não tenho nada contra Porto Velho porque foi aqui que nasci, que me criei, tenho até certo carinho pela cidade, mas sei que ela não tem muita coisa a oferecer. O lugar dessa cidade que mais é presente em minha memória é a rua daqui da casa da mamãe, esse bairro, porque a gente era pequena e brincava muito na rua. Sempre fui muito sapeca, muito moleca. Nunca soube 
o que era brincar de boneca. Minha irmã gostava, brincava de boneca, eu nunca gostei, agora de tudo que era brinquedo de menino eu brincava. Acho que até os meus treze anos vivia na rua empinando papagaio.

Eu andava que nem menino... Certa vez, lá na Vila, eu estava de short de lycra bem curtinho, tipo de banho, sem blusa e descalça, acho que devia ter uns nove anos, dez anos e não estava nem aí para o que os outros pudessem falar. Saí daquele jeito. Na época tinha uma padaria e um mercadinho ali onde é o Nerikas agora, fui correndo até esse mercadinho comprar farinha para minha mãe e voltei também correndo, aí um policial que morava na Vila, na primeira rua, me viu correndo com o saco de farinha na mão, descalça, sem blusa, neguinha, e me parou, achou que eu fosse alguma trombadinha que estava indo roubar. Imagine: neguinha, descalça, sem blusa e correndo. Ele deve ter pensado: “Oxente, essa daí é uma favelada, deve estar roubando”. Aí fui explicar que tinha ido comprar farinha, que minha mãe tinha mandado.

Hoje não gosto mais de comer farinha, parece que meus dentes são sensíveis, se mastigo coisas duras eles doem, não sei se é por causa do aparelho que meus dentes ficaram assim. Antes eu comia farinha seca. Gosto de fritas, bife a milanesa. Sou fã mesmo de batata frita, macarronada, lasanha. Não tenho muita frescura para comer, como de tudo, com exceção de beterraba batida no liquidificador e mastruz com leite. Lembro que as meninas faziam quando eu era mais novinha e não tinha quem me fizesse tomar, se eu tomasse vomitava, mas comer, como de tudo. Das comidas regionais a que mais gosto é de Tacacá, gosto da sensação da folhinha do jambú, que deixa a boca tremendo.

Quanto a meus dotes culinários, acho que não deixam a desejar. Quando pequena morria de vontade de aprender a cozinhar. Via meu pai cozinhando - era ele quem mais gostava de cozinhar lá em casa - ficava observando cada gesto. Certa vez, quando ele estava com paciência, me ensinou a fazer arroz, daí eu mesma, sozinha, fui observando as pessoas e aprendendo a fazer as outras coisas. Hoje me viro como posso.

O básico da cozinha sei fazer: bife, galinha, peixe assado, cozido, frito, sei fritar ovo, me viro num miojo quando estou com preguiça de fazer um almoço, ou uma janta. De sobremesa só sei fazer mousse, pavê e gelatina. Aprendi a fazer bolo quando tinha uns 15 anos, lá em Ariquemes. Eu e meus irmãos fomos passar um final de semana lá, com uma tia nossa, e ela me ensinou a fazer. Daí falou: “Agora você faz!” Fiz um bolo belezinha, mas esqueci de colocar o trigo, então não cresceu, ficou gostoso, mas não cresceu, ficou parecendo gelatina. Nessas férias que a gente passou em Ariquemes, meu tio inventou de cortar o cabelo do meu irmão, corte militar, na máquina zero. Meu irmão ficou muito puto, começou a chorar aí fui bagunçar com ele, falei: “Parece que você é gay, fica chorando”, ele virou o bicho correndo atrás de mim, querendo me bater. Tiveram que segurá-lo. 
Anos depois, quando o Caio passou no vestibular uma cena como aquela das férias se repetiu. Peguei uma máquina que tinha lá em casa, profissional, e fui cortar o cabelo dele, fiz um buraco e para sacanear passei o zero: “Agora vai ter que passar o zero em tudo” e ele: "Carol, você é muito filha da mãe!” Comecei a passar a máquina e ela quebrou, fez aquele maior barulho. Sei que a cabeça dele ficou cheia de buracos, aí esperamos o meu pai chegar para leválo ao salão e raspar todo o cabelo. Esse foi o nosso trote para ele. Em faculdade particular essa coisa de trote quase não existe, agora na UNIR, em universidade federal é inevitável. Cortam o cabelo, pintam o corpo, melam você de maionese e essas coisas todas. Em faculdade particular nunca vi o pessoal dando valor para trote. Onde estudo nem tem essas coisas.

Essas são as minhas lembranças. Só brincava com menino, era difícil brincar com menina porque as meninas da minha época só gostavam de boneca, essas coisas, e eu não, só gostava de carrinho. Preferia brincar com o meu irmão e com os amigos dele, era muito encrenqueira, mexia com os meninos, ficava encrencando. Lembro que tinha o Alexandre lá na Vila, a gente zoava com aquele menino! Éramos vizinhos. Ele morava do lado de lá da caixa d’água e a gente morava do lado de cá. Ele ia lá para casa direto e a gente ficava bagunçado porque quando ele falava, ficava uma babinha assim no canto da boca, dava um nojo. A gente dizia: “Alexandre, pega lá um jambo que quando você chegar a gente te dá um beijo”, aí o bichinho ia lá, pegava o jambo, mas quando chegava a gente estava chupando laranja, e dizia: “Te enganei!”.Ele dava as costas, montava na bicicleta, a gente puxava as calças dele e jogava o bagaço da laranja dentro. Minha irmã e eu éramos más quando pequenas.

Fora a época do papagaio, que eu era gaiata. Às vezes os meninos estavam com papagaio na mão, brincando na rua, eu ia lá, tomava e corria com tudo para casa. Não tinha quem me pegasse na corrida! Só ficava menino batendo lá na porta de casa, pedindo para eu devolver o papagaio. Uma vez passou um menino por mim, de bicicleta - era um colega nosso - aí eu sentei um tapa nas costas dele, e falei: “Ei colega!” Sentei um tapa que ficou marcado, vermelho, aí a mãe dele foi lá em casa brigar: “Sua filha bateu no meu filho, porque não sei o que lá...” Minha mãe falou: “Carolina está aqui em casa, ela falou que não bateu no seu filho, que nem conhece o seu filho”. Ela me defendeu porque falei que não tinha batido, que era mentira e que era ele quem sempre vinha mexer comigo. Uns tempos atrás, depois que eu já era adulta ela se lembrou desse episódio e veio me falar, eu disse que tinha batido mesmo nas costas dele. Ela falou: "É né, você é sem vergonha, me fez brigar com a mulher, chamar a mulher de mentirosa e você realmente tinha batido no menino!”

Os colegas do Caio iam lá em casa, eu pegava o cinto e ficava na porta querendo bater neles. Lembro do Léo, irmão da Raquel, que uma vez disse: "Se você encostar esse cinto em mim vou te dar uma porrada!”. Fazia isso por besteira, por gaiatice, gostava de mexer com os 
meninos para eles ficarem com raiva de mim. Tinha um menino baixinho que lutava judô, sempre estava de quimono, aí uma vez fui mexer com ele, falei: "Esse quimono não está com nada, eu duvido se você não apanha de mim!”, ele já lutava e eu fiquei empurrando ele: “Então vamos lutar aqui”, puxei o quimono e ele me jogou no chão, ai também não mexi mais com ele, parei, quase levo um golpe. Era gaiata quando pequena, aí, quando cresci virei uma pomba lesa, não mexo mais com nem uma mosca. Sou tímida, e já fui ainda mais há uns quatro anos atrás.

Lembro também que não parava empregada em casa porque éramos muito sapecas, infernizávamos a vida delas. Uma vez a empregada estava trabalhando dentro de casa e a filha dela levou uma boneca daquelas que por dentro são cheias de bolinhas de isopor, aí tomamos a boneca da menina, penduramos em uma coluna de madeira, e tacamos fogo. A menina ficou chorando: “A minha boneca!” e a boneca queimando, aí veio a mãe dela apressada, irritada, com um cinco para bater na gente, mas quem disse que nos pegava? Quando a Carla chegava a gente contava tudo para ela segundo a nossa versão e falava que era mentira a versão das outras pessoas, claro que ela brigava que só com a gente, tentando nos educar e nem sempre acreditava na gente. Essa empregada foi embora lá de casa, com raiva.

Em outra ocasião tivemos uma empregada que dava chá de cascas de árvores para o meu irmão tomar. Minha mãe chegava e ele estava com o bucho inchado, não sabia o que ele tinha, porque ele não falava nada, até que um dia falou, ou ela descobriu, não sei, que a empregada estava fazendo chá de coisas estranhas e dando para ele tomar. Ela tirava a casca de uma árvore velha que tinha em frente de casa e dava para a gente tomar, aí a gente passava mal, ficava ruim, com a barriga estufada de tanto tomar chá velho. Ela foi mandada embora.

Passou muita empregada pela nossa casa quando a gente era criança. Teve uma que era amarelada e inchada de tanta anemia. Só comia ovo, só ovo, ovo, ovo. Perguntei por que ela não comia arroz, feijão, e ela disse que era porque uma vez foi comer feijão e uma casquinha entrou do dente dela, ela ficou com nojo e nunca mais comeu. Uma leseira a desculpa da menina.

Minha mãe ficava preocupada com essa nossa ajudante, tinha medo de ela morrer, ir parar no hospital, ter que pagar uma indenização porque ela não se alimentava direito e era anêmica que só. Não sei o que foi que aconteceu que ela foi embora, mas em vez de falar que não queria mais trabalhar e receber os direitos dela: décimo terceiro salário e tudo, simplesmente foi embora! Num belo dia, quando amanheceu, fomos para a varanda e vimos que tinha dois espetos de churrasco escorados na porta, e que esta estava aberta. Tinha algumas coisas dela que ficavam no quartinho que dava para essa varanda, ela foi lá de madrugada, a gente não sabe como que ela entrou, se ela pulou, a chave ficava na porta pelo lado de dentro, ela abriu a porta, catou umas coisinhas dela que tinha lá no quartinho, acho que ainda pegou alguma coisa nossa, foi embora e deixou dois espetos escorados na porta. Tipo assim: se alguém acordasse, ela estava 
protegida, estava armada, entendeu? Até hoje a gente não sabe o que aconteceu. Minha mãe foi na casa dela, conversou, falou que ela não precisava ter feito aquilo, que ela escapou porque a gente poderia ter chamado a polícia e ela poderia ter ido presa. Algumas aventuras de empregada.

A última empregada que tivemos foi a Mara, que morou com a gente dos meus sete aos dez anos. Quando completei dez anos ela faleceu na cachoeira. Ela dormia em casa, fazia comida para a gente, levava a gente para a escola, buscava. E minha irmã a acompanhava em sua rotina, acordava cinco horas da manhã, junto com ela e ia para a cozinha, vê-la preparando o café, arrumando a mesa. Lembro que quando a Mara faleceu a Camila continuou acordando cinco horas da manhã, perambulando sozinha pela casa, não conseguia dormir.

Lembro do dia da morte de Mara como se fosse hoje: ela estava sentada naquela muretinha, tinha uma prima dela que estava morando na casa aqui da esquina, do seu Raimundinho e veio chamá-la para ir para um banho em Fortaleza do Abunã. Insistiu tanto que a Mara acabou aceitando. Depois fiquei sabendo que ela e essa prima tinham sido inimigas mortais e que acharam uma agenda atrás do armário da Mara, escrito: "Vera eu te odeio, Vera eu te odeio” a agenda inteirinha assim. Vera é o nome dessa prima dela. A Mara teve um filho, esse filho faleceu e não sei por que elas tinham uma mágoa uma da outra. Acho que tinha alguma coisa a ver com essa criança.

A Mara estava com a minha família em Fortaleza do Abunã, aí a Vera chegou com uns caras em uma canoa, uns caras que ela conheceu por lá e a chamaram para dar uma volta pelo rio. Canoa não, voadeira. Chamaram a Mara para ir passear com eles e ela aceitou, foram em direção ao tombo da cachoeira, sentaram-se em uma pedra e não sei o que aconteceu que a Vera caiu, a Mara foi puxá-la pela mão e não se sabe quem puxou quem, se foi acidental, se foi proposital, só sabemos que a Mara desapareceu. Ficamos pensando mil e uma coisas. Elas eram inimigas mortais, de repente ficam amigas, vão para a cachoeira, quem cai é a Vera, a Mara vai salvá-la e morre. Essa é versão da Vera e dos rapazes. Eles a viram afundando, mas não conseguiram salvá-la. Até hoje o corpo não foi encontrado para ser velado. Mara foi a melhor empregada que a gente teve em casa e gostávamos muito dela.

Bem, falei dos meus dotes culinários, do desejo de construir família, da importância da minha família, de minha experiência na ocupação Chico Mendes, de minhas travessuras de criança, mas falta uma coisa: minha paixão por ouro. Desde pequena que gosto de ouro, que nem naquela novela O Clone: ixalá! Tem umas fotos em casa de eu bebezinho, usando um colar de ouro grossão. Naquela época ouro não era tão caro por aqui, por causa do garimpo. Agora, depois de grande, me desfiz das minhas jóias. Está tudo empenhorado na Caixa Econômico, mas eu era cheia de ouro, eram três pulseiras em um braço, anel por cima de anel, cordão. O pessoal 
me chamava de garimpeira. Tinha cordão grosso com meu nome, com pingente, mas tive que me desfazer de tudo, eu não, minha mãe.

Hoje, parece que estou nua, sem pulseira, sem cordão, estava tão acostumada com brinco... Quando tirei meu cordão e penhorei, me senti nua e feia. Parece que o que me fazia ficar bonita era meu cordão, meus brincos, a pulseira, o anel. Sempre fui muito ligada a ouro, ficava com um dó quando tinha que penhorar alguma coisa. Agora só tenho um anel de ouro, essa pulseira que estou usando é de metal comum. Só conservei este anel porque gosto muito dele, ele era um brinco da Madona, pertencia à minha mãe, aí ela perdeu um lado, mandou derreter o que ficou e fez dele um anel para usar no dedo mindinho. Quando ela o tirou da Caixa eu o juntei com um pedaço de pepita que tinha em casa, mandei aumentar e agora uso no dedo anelar. É o único que me restou. 


\section{Camila}

“Se eu precisar me casar, abrigar um filho não vou ter um lugar que seja meu.”

Não tenho muito o que falar... Acho difícil falar sobre mim porque isso não é algo que esteja acostumada a fazer...

Meu nome é Camila, nasci em Porto Velho em 20 de Fevereiro de 1987, e desde então resido aqui. Não tenho muitas lembranças de minha infância nem da cidade. Lembro apenas que a cidade, para mim, era um matagal, alguma coisa jogada... Recordo também que na escola a gente fazia piquenique. Levávamos lanche, uma toalha xadrez e a estendíamos no chão, sobre uns matinhos. Na hora do intervalo a gente se sentava para lanchar. Nessa época acho que tinha uns dez anos.

Hoje a cidade deu uma transformada, mas pouca, por causa da corrupção. Os políticos que roubam prejudicam muito o desenvolvimento da cidade e da população. Eles falam que vão fazer as coisas e não fazem. Corrupção é um dos problemas mais sérios de Porto Velho, porque geram outros.

Apesar de ter me criado aqui, não acho essa cidade especial, não me lembro de nada muito significativo que tenha vivenciado nela, e seu único lugar que aprecio é o porto. Gosto de ir para lá, olhar o rio Madeira, ver o pôr-do-sol. É um lugar bom para ir com a família, apesar de estar abandonado pelo Poder Público.

Tive uma experiência política na comunidade Chico Mendes, mais por apoio a meus irmãos do que por convicção de que aquela ocupação fosse vigorar. Fui para lá com o objetivo de conquistar uma casa, mas sinceramente, estava ali sem ter muita esperança de que fosse dar certo. Ficava pensando: "Será que vai dar certo? Se der vou construir meu barraquinho e morar aqui. Se não der certo, paciência, temos que tocar a vida para frente”. Não tinha muita convicção por causa da falta de compromisso das pessoas e dessa tradição que tem no Brasil, de o rico ter a Justiça ao lado dele, ter o poder, e o pobre não ter apoio nenhum. Infelizmente houve o despejo e foi uma tristeza muito grande.

Não posso afirmar que sou sem-teto, moro na casa que meus pais compraram para a gente morar, mas também não posso afirmar que tenho uma casa, porque não tenho. Se eu precisar me casar, abrigar um filho não vou ter um lugar que seja meu.

Faço faculdade de Pedagogia, estou no terceiro período e tenho muitos planos para minha vida. Primeiro pretendo terminar a faculdade, para depois passar num concurso, arrumar um emprego e poder fazer o curso que realmente desejo, que é Psicologia. Tentei vestibular para Psicologia na UNIR umas duas vezes, mas não passei. Faço Pedagogia porque é um curso mais barato, é o que posso pagar, mas o que quero mesmo é ser psicóloga. Identifiquei-me com essa 
área, gosto muito de conversar, de dar conselhos. Minhas amigas me procuram muito para falar sobre suas vidas, seus problemas...

Sou uma pessoa compreensiva e muito vaidosa. Adoro brincos, pulseiras, maquiagem, perfume, roupa. Ando sempre cheia de acessórios, não saio sem minha bolsa, sem minhas argolas e meu celular. Todos os meus acessórios são especiais para mim. Tenho esse anel que todo mundo pensa que é aliança de noivado, mas não é. Era um anel de três argolas, ai quebrou, dei uma parte para minha irmã, a outra enegreceu e essa uso todos os dias. Uso porque meu outro anel quebrou e não gosto de ficar sem anel. Mas todo mundo que o vê pergunta: "Você está noiva?”. Ainda não estou e acho que vai demorar algum tempo para isso acontecer.

Minha infância foi como a de muitas crianças: brincar, se divertir, estudar, sair com a família. Tive uma família maravilhosa, bom pai, boa mãe, irmãos excelentes.

Brincava de boneca, de casinha, de moda. Vestia as roupas da minha mãe, calçava os sapatos de salto dela e saía desfilando pela casa. Já os meus irmãos iam para rua, empinar papagaio. Eu ficava em casa, toda quietinha. Dia de chuva eles brincavam lá fora e eu ficava em casa, quietinha, assistindo desenho animado. Sempre fui a mais calminha da família.

Quando brincava de casinha, gostava de ser a mãezinha. Se fosse brincar de casinha falava logo: “Ai, eu vou ser a mãe, vou mandar em tudo”. Nem entendo direito o porquê dessa minha identificação com a figura materna. Só queria ser a mãe...

Hoje penso em ter filhos e por incrível que pareça, essa noite mesmo sonhei que estava grávida, que minha filha era uma menina linda, bem branquinha e gordinha. Sonhei com isso, acredita?

Se eu tiver uma filha pretendo educá-la com todos os princípios com os quais minha mãe me educou. Tudo o que minha mãe passou para mim, vou passar para ela. Filhos a gente cria para o mundo e não para a gente, então temos que prepará-los bem, dar a eles todas as informações e instruções, mas ter filhos, constituir família está, para mim, em um projeto a ser desenvolvido em longo prazo.

Dependo financeiramente de pai e mãe, preciso primeiro terminar a faculdade, arrumar um emprego. Sei que imprevistos acontecem, as coisas nem sempre saem do jeito que a gente quer, e se acontecer, meu filho vai ser muito bem vindo! Mas primeiro preciso terminar a faculdade.

No começo não gostava do curso de Pedagogia, empurrava com a barriga, porque foi assim: teve vestibular, minha mãe falou: "Você vai fazer!" E eu disse: "Mas não quero esse curso!”. Ela falou: “É esse que eu posso pagar para você!” Ela me deu duas opções: Pedagogia e Administração de Empresa. Escolhi Pedagogia, fiz a prova e passei. No primeiro semestre fui 
empurrando com a barriga, no segundo comecei a gostar e estou cursando até hoje, estou me identificando e pretendo concluí-lo.

Estava estagiando na área, meu estágio terminou sexta-feira passada. Agora estou esperando a dona da escolinha me ligar, para ver se vai me contratar ou não. Se ela me chamar vou ficar com o maternal, e futuramente posso até conseguir uma sala de aula mesmo, para alfabetizar. Isso conta como estágio.

Já tive uma experiência de trabalho semelhante, porque minha mãe tinha uma escolinha, eu trabalhava com ela, então aprendi um pouco de como lidar com crianças. A escolinha da minha mãe tinha berçário, hotelzinho que funcionava a noite e a parte da alfabetização. Tinha criança que ficava em período integral, os pais só iam buscar no final da tarde e tinha crianças que ficavam só um período. Trabalhávamos nessa escola minha mãe, minha tia, minha irmã e eu, mas depois de certo tempo encerramos as atividades, fechamos, porque minha mãe estava como diretora de uma escola estadual, a Eduardo Lima e Silva, então quase não tinha tempo.

Minha mãe acabou sendo passada para trás pela irmã dela, que a substituiu por uma amiga. Mas o que aqui se faz aqui se paga! Ela mudou a escolinha ali para a Avenida Guaporé, e essa menina amiga dela a enganou. Hoje ela está ai, não adiantou nada... Minha mãe fazia os projetos para a escolinha e minha tia dizia que era ela quem tinha feito, mas na verdade, minha tia entrou sem saber nada...

Minha mãe pretende abrir uma escolinha de novo, e gostaria de trabalhar novamente com ela, seja como psicóloga, como psico-pedagoga ou mesmo como professora. 


\section{Caio}

\section{“Está complicado ter uma casa hoje em dia”}

Fui participar da ocupação Chico Mendes pela necessidade de ter uma casa. Sou casado, minha esposa e eu vamos ter um filho. A gente se casou e ainda não tem onde morar, pagamos aluguel e é difícil, é apertado. Hoje em dia é muito difícil conseguir uma casa. O Governo faz programas de financiamento, dizem que esses programas são para pessoas carentes, para as pessoas que não têm condição, mas você não consegue financiar uma casa pela Caixa Econômica, por exemplo, se ganhar menos de R\$: 1.200, 00. Essa é a nossa realidade aqui.

Vi a ocupação como um recurso para conseguir minha casa, arrisquei, se eu conseguisse: beleza! Se não conseguisse também não ia perder nada, então valia a pena correr o risco. Trabalhei bastante na ocupação, participei de todas as reuniões, o pessoal estava bem organizado. A gente sempre fazia mutirão para construir as estradas, abrir as ruas, demarcar os terrenos, levantar os barracos. De vez em quando dava alguma confusão, briga de mulher descabelada, uma puxando o cabelo da outra, mas no final estava todo mundo se abraçando, todo mundo amigo de novo, porque todos estavam com um mesmo objetivo: conseguir uma casa.

Trabalhei muito no meu terreno, rocei, carpi, cerquei. Na casa onde moro tinha uns pés de açaí, que estavam prejudicando a estrutura do muro, aí o vizinho acionou a Secretaria de Meio Ambiente para poder cortar o açaizeiro, a gente cortou ele todo em formato de ripas estreitas e eu aproveitei essas ripas para cercar meu terreno na ocupação. Cerquei com madeira de açaí e arame farpado, porque é o que estava custando mais barato. Sei das críticas que o Movimento faz ao uso de arame farpado, sei que não é bonito, que é até perigoso, mas a gente usa aquilo que está acessível. E foi preciso cercar porque estava dando muita confusão, gente invadindo terreno dos outros, agindo com esperteza, problemas de demarcação... Cerquei tudo, depois peguei mais uma graninha, comprei três sacos de cimento, e meio milheiro de tijolo, para poder fazer o baldame do meu barraco, mas estava com medo de construir e um suposto dono aparecer e destruir o meu trabalho, porque dizem que é assim: sempre que as pessoas ocupam, que limpam a área, passam o trator, cavam poço, puxam luz, começam a habitar, a polícia aparece e faz o despejo. Dizem que isso já aconteceu quatro vezes. Então fiz só o baldame para segurar o terreno e ver como ia ficar a negociação, para não sair perdendo tanto, caso viesse ordem de despejo.

Arrisquei, fiz lá, deixei sempre limpinho o terreno e ia para lá sempre que podia, quase todos os dias. Passava os finais de semana todos lá, só voltava no comecinho da noite, porque não tinha condições de dormir, não tinha a casinha montada.

Infelizmente tivemos o despejo e agora não sei como vai ficar, não tenho muito contato com o pessoal da liderança. Vou ficar indo lá sempre, para ver como está e se o pessoal resolver 
voltar, resolver ocupar de novo, irei junto. As pessoas falam que vão ocupar novamente, mas é preciso dar um tempo, até para a gente se organizar melhor, ainda nem tem 48 horas que aconteceu o despejo. Mas acho meio complicado, porque se já tiraram a gente uma vez, podem tirar de novo, mas não há nada que impeça a gente de tentar.

Acho que a cidade está crescendo bastante em termos populacionais, devido à natalidade - as pessoas estão tendo mais filhos - e devido também a migração. Tem muitas pessoas vindo para cá e isso reflete na questão da moradia. Os alugueis, em questão de pouco tempo aumentaram bastante e o preço das casas também. Hoje você não consegue comprar uma casa decente em Porto Velho por menos de R\$: 50.000. Por esse valor você compra uma casa simples, às vezes compra só um terreno. Está complicado você ter uma casa hoje em dia em Porto Velho. Para financiar eles não financiam para qualquer pessoa, para qualquer renda. Se você ganhar um salário mínimo não consegue financiar uma casa pela Caixa Econômica, e os programas da Prefeitura funcionam acho que só para justificar a existência de tal setor, por exemplo, de uma secretaria que mexe com habitação, porque enquanto tem milhares de famílias sem moradia eles constroem um conjunto de 30 casas populares. Trinta casas populares não vão resolver o problema, mas eles colocam na propaganda, tudo bonitinho, como se estivessem fazendo, correndo atrás. Não são 30 pessoas que necessitam de casa, são milhares de famílias, e Porto Velho tem muita terra em perímetro urbano que o pessoal não faz benfeitoria, não liga, não cuida, fica lá parada, inútil, enquanto tem tanta gente precisando de um lugar para ficar. É difícil, mas tem que tentar de alguma forma, ou então você vai morar na rua. Como não quero morar na rua, tenho que conseguir um lugar para mim.

Sonho em ter uma casa simples mesmo, mas arrumadinha, com três quartos, uma sala, uma cozinha, um banheiro, um quintalzinho para fazer alguma coisa, uma horta, alguma coisa assim... Quero que minha casa tenha uma árvore para pendurar um balanço para a molecada brincar.

A primeira casa que morei, na minha infância, era de madeira e de assoalho suspenso, o piso não era direto no chão. A gente criava umas galinhas, elas dormiam em baixo desse assoalho. Essa casa ficava no quintal da minha avó. Eu tinha uns três anos, nunca me esqueci. Depois fui morar na Vila da Eletronorte, porque meu pai arranjou emprego nessa empresa. Fomos morar em uma casinha de alvenaria, bem pequena, mas aconchegante. Morei na Vila dos meus cinco anos até o final da adolescência, junto com meus pais e minhas irmãs. Depois dessa casinha de alvenaria a gente se mudou para uma casa de madeira, que era melhorzinha, mais espaçosa.

Saímos da Vila porque teve um programa de demissão voluntária, meu pai se demitiu, pegou um dinheiro... A gente teve que vender a casa porque estava precisando de dinheiro. 
Compramos uma outra, mais em conta, fora da Vila, e sobrou um dinheirinho para quitarmos umas dívidas.

Minha relação com minha família, com meus parentes em geral é boa. Acho que me relaciono bem com todo mundo porque sou muito de apaziguar. Não gosto de briga, de desunião, então, sempre que tem alguma coisa, algum atrito, evito apoiar um ou outro, tento ser imparcial e amenizar a situação, porque acho que não vale a pena. Quando se trata de família, hoje você briga, está com raiva, mas amanhã já está todo mundo se falando, está tudo bem, então é uma coisa que acho que não vale a pena. Família para mim é muito importante e união também.

Agora constituí nova família e desejo que fique tudo bem, que minha esposa e eu possamos levar uma vida tranqüila. Quero ser o mais amoroso possível com ela, sempre, e também quero receber dela afeto. Quero criar meus filhos com dignidade, ensinar a eles os valores cristãos. Educar, mostrar como é o mundo, que a vida não é fácil, mas mostrar da forma menos dura possível, pelos caminhos menos dolorosos. Quero dar uma vida digna para minha família e espero levar uma vida feliz. Sei que de vez em quando vão aparecer problemas, como em todas as famílias, mas espero ter força para resolvê-los e superar todas as tribulações que vierem.

Acho que a primeira coisa para se resolver qualquer problema é a conversa, a gente tem que conversar, esclarecer os fatos, ser meio advogado assim... Fazer com que as duas partes se entendam. Tenho um lado espiritual bastante forte, sou muito crente em Deus, durante toda a minha infância estudei a Bíblia. Minha mãe é testemunha de Jeová, então sempre tive contato com o lado religioso, só que os meus problemas tento resolver eu mesmo, e não deixar para Deus, mas se eu ver que está muito difícil dou uma apeladinha para Ele. Deus já tem problemas demais para resolver, acho melhor a gente mesmo tentar resolver nossas coisas. Agora se for uma questão de doença na família, alguma coisa grave, aí já é outra história, porque está além de nós, das nossas forças e das nossas vontades, então precisamos buscar força com quem a possui. Aí é só pedindo ajuda para Ele mesmo.

Para além dos meus problemas pessoais, me preocupo com os problemas do mundo, como a violência e o aquecimento global, e me angustio, porque não vejo solução. O ser humano é muito ambicioso, muito egoísta. Tudo gira em torno de quem pode mais, quem tem mais, então acho que esses problemas nunca vão deixar de existir e a tendência é só aumentar. As pessoas falam que é progresso. Para obter o progresso não medem as conseqüências, vou dar o exemplo dessas duas usinas que vão ser construídas aqui no Rio Madeira, as hidrelétricas de Santo Antonio e Jirau. Em nome do progresso eles vão inundar uma grande área de terra e segundo uma pesquisa que li na internet, vão acabar com sete espécies de peixe, fora as pessoas que moram na beira do rio, chamadas de ribeirinhos, que vivem da pesca, da caça há centenas de 
anos, há várias gerações, no seu tempo certo... E querendo ou não, isso é uma mistura de violência com agressão ao meio ambiente. Tudo em nome do progresso, em nome de produzir mais, querer mais. Para que fazer isso? Para gerar mais energia. Para que gerar mais energia? Para as indústrias produzirem mais. Para que as indústrias produzirem mais? Para a economia do país crescer. Para que a economia do país crescer? Para poder competir com as grandes potências, então, é uma relação que não tem jeito.

O ser humano peca pela própria ambição. Todo mundo poderia ter o suficiente para viver, antigamente era assim: todo mundo plantava, colhia, se ajudava, fazia trocas. As pessoas tinham o que comer, trabalhavam para isso e sustentavam suas famílias tranquilamente, hoje em dia as coisas mudaram. Os valores se inverteram, tudo se resume em consumir e as pessoas parecem estar sempre insatisfeitas. Estão sempre querendo mais.

Por falar em sustento, quero dizer que sou uma pessoa simples, que não gosta de desperdício e se alimenta de forma básica. Gosto de um arroz, um feijão, um bifinho acebolado, uma bistequinha de porco, legumes em geral. Tenho um paladar simples, até mesmo se for comer fora de casa, é disso que me sirvo, é isso que coloco no meu prato. Às vezes tem um monte de coisas diferentes, estrogonofe, aquelas comidas sofisticadas, mas fico com o meu arroz com feijão mesmo, porque é isso que vai garantir meu sustento no meu dia de trabalho. E como bom caboclo, adoro uma farinha. De doces gosto de brigadeiro e doce de leite. Fruta não tenho nenhuma especial e consumo pouco. As que mais gosto são banana e maçã.

Não sou muito bom na cozinha, só sei fazer as coisas que gosto de comer. Aprendi sozinho, desde molecote, porque meus pais trabalhavam fora e eu tinha que me virar. Antigamente, bem antigamente, quando estávamos melhores de situação tínhamos uma pessoa que fazia o almoço, cuidava da casa, mas aí, quando a situação foi piorando, minhas irmãs e eu passamos a fazer a comida e cuidar da casa. A gente dividia, um fazia o arroz, outro a carne, o feijão. Quem lavava as louças era a Camila, mas de vez em quando a gente revezava, ou minha mãe lavava, quando chegava do trabalho. Nem me lembro direito como era. Mas nem sempre a gente almoçava em casa, porque se brincar, a maior parte do tempo a gente viveu na casa da minha avó e perturbamos muito! Minha mãe é muito ligada à mãe dela, às vezes meu pai reclamava, ficava até meio chateado, mas não tem como né? é a mãe dela.

Na casa de minha avó era um entra e sai de gente, porque fica no centro da cidade, perto do trabalho de todo mundo, então toda hora tinha um dando uma passadinha por lá, principalmente na hora do almoço e de tarde, no fim do expediente. As pessoas iam para lá, conversavam e depois retornavam para suas casas. Sempre teve muito movimento na casa de minha avó e de vez em quando a gente fazia um churrasco, uma coisinha ou outra, para reunir a família. 
Na minha infância tive muitos amigos, tanto na Vila, onde morava com meus pais, quanto no Centro, onde morava com minha avó. Brincava muito na rua, jogava bola, empinava papagaio, jogava peteca, bolinha de gudi, mas era meio regrado porque minha mãe era muito preocupada e rígida com a questão de horário. Não podíamos ficar brincando até tarde na rua. Eu tinha muitos amigos, era bem sociável, tanto no bairro quanto na escola. Gostava muito de estudar, cheguei a ser líder de classe e líder religioso - estudei em uma escola salesiana - então tinha eleições para líder de classe e líder religioso, e cheguei a ser os dois ao mesmo tempo, porque era dedicado aos estudos e me dava bem com os colegas.

Minha matéria favorita, no meu tempo de escola, era História. Achava legal o desenrolar dos acontecimentos antigos: o descobrimento dos países, as guerras, os acordos, os tratados e todas as outras histórias, os pequenos acontecimentos que estavam relacionados aos grandes fatos. Achava bacana, interessante.

Gostaria que a história do Brasil, daqui para frente fosse diferente do que tem sido até agora. Nosso principal problema, a meu ver, é a desigualdade social, o valor que é dado às profissões. Um gari, a pessoa que limpa a rua, limpa a cidade, deveria ser considerado tão importante quanto o médico que trata o paciente. Se todo mundo fosse médico, fosse advogado ou frentista de posto de gasolina, quem ia limpar a cidade? Quem ia cultivar alimentos? Acho que não deveria haver distinção nos salários, nem juízos de valor: quem é melhor, quem é pior, porque todas as profissões são importantes. Se não houvesse gari o médico ia ter que assumir seu trabalho, porque as ruas não poderiam ficar sujas, as praças não poderiam ficar sujas. Alguém teria que fazer esse serviço, porque se não a situação ficaria insuportável.

Cada tarefa tem seu mérito, tem sua importância, mas há uma diferença muito grande na remuneração. Enquanto um médico ganha, digamos, dez mil por mês, um gari ganha um salário mínimo. Com um salário mínimo você não faz nada. Aqui em Porto Velho é difícil conseguir alugar uma casa por menos de R\$: 250,00, e isso em um bairro bem afastado mesmo, sem infraestrutura. Um salário mínimo é 400 e pouco, você tem que pagar água, luz, alimentação para a família, transporte. Esse é um dinheiro que seria para você gastar apenas consigo mesmo, só com comida. Para você viver decentemente precisaria desse dinheiro para gastar apenas consigo mesmo, mas o cara se vê tendo que sustentar a família com isso. É complicado e enquanto não acabar essa desigualdade o Brasil não vai sair desse buraco.

Para acabar com os problemas sociais do Brasil penso que é preciso investir em educação. A educação é a base de tudo, porque se a gente educar as crianças bem, fizer um trabalho bom de conscientização social, daqui há uns 20 anos essa criança vai ser um futuro presidente, um senador, um deputado mais preparado do que os que temos hoje, mais consciente e preocupada em resolver os problemas dos cidadãos. Elas vão se preocupar mais com 
saneamento básico, com a saúde pública, vai ser uma cidadã consciente, então, você educando bem as pessoas, vai ter um reflexo melhor lá frente. Para mim, essa educação ruim que a gente tem hoje é uma estratégia da elite dominante desse país, para manter essa situação de extrema desigualdade, que só é favorável a ela. Manter o povo burro é mais seguro para ela, porque povo inteligente, que pensa, que questiona não se submete a qualquer coisa.

Penso que a solução é para longo prazo, que a nossa geração não vai conseguir mudar nada. É como se precisássemos da criação de uma nova espécie, porque nossa geração não tem como, já está formada, deformada. Está tudo muito sujo, muito viciado, à vezes você tem uma idéia de mudar as coisas, melhorar, mas é podado. Ou você anda no mesmo passo que eles ou você se omite, para não sofrer as conseqüências. É complicado, e como diz o adágio popular: “uma andorinha só não faz verão”. A única esperança que tenho para um Brasil melhor, para uma história melhor para o Brasil está na educação.

Você vê países supostamente menos desenvolvidos que o Brasil, com uma Economia mais fraca, mas que conseguem combater esses problemas que o Brasil possui: como a desigualdade social, a fome, a educação. Aqui pertinho mesmo, a Argentina, tem uma economia que não é forte, não tem muitos recursos assim, mas onde as pessoas são mais instruídas, o índice de analfabetismo é quase zero, e o Brasil é um país tão rico, mas não consegue fazer isso, porque tem muita corrupção. A corrupção está entranhada, está muito forte no centro do poder. Até mesmo os ícones do passado, que lutaram na época da ditadura, que queriam fazer a revolução, melhorar as coisas, hoje estão no poder e sujaram a sua história, fazendo coisas erradas. São corruptos atualmente, se envolveram com pessoas e coisas erradas. É complicado.

Por causa da corrupção as cidades estão degradas, a condição de vida das pessoas está degrada. As pessoas têm medo uma das outras, têm medo de sair de casa. Em Porto Velho falta o que falta em todo o lugar. Entra governo, sai governo e fica tudo do mesmo jeito. Falta alguém que se preocupe com o bem-estar social, que dê qualidade de vida porque a cidade está muito suja, seu aspecto não é agradável. Quando a pessoa está em um lugar ruim, mal cuidado, ela acaba sem gosto por aquele lugar, acaba não cuidando, não querendo bem. Rio Branco do Acre, aqui pertinho, é uma cidade bonita, bem cuidada, agradável. Trabalhei lá dois anos e pude observar essas coisas.

Quando as pessoas moram em uma cidade bem cuidada, têm orgulho de serem de lá, têm amor pelo local. As pessoas de Rio Branco têm orgulho acreano. Quem fez isso com a cidade foi um prefeito do mesmo partido do daqui de Porto Velho, do PT, mas o daqui não conseguiu. Rio Branco era considerada uma cidade muito ruim, pior até que Porto Velho, mas em oito anos uma boa administração fez daquela cidade uma cidade modelo, é um lugar que nem tem tantos recursos, não tem uma agricultura forte, não tem indústrias, nem um comércio muito 
forte. Rondônia é um Estado muito rico em produção. Tem agricultura, tem pecuária, tem garimpos, e mesmo assim tudo aqui é bagunçado porque os políticos são ruins e os cidadãos também não se importam muito, não cobram. Puxa, se o cara fez lá, porque não se pode fazer aqui também? Vejo isso como uma falta de preocupação e de zelo pelo lugar. Os políticos só entram para roubar, para favorecerem a si próprios.

Existe, em Porto Velho, um lugar que me é particularmente especial, um lugar de memória, porque o freqüentava muito quando era menino. Trata-se do Parque Circuito. Gosto de lá porque é bem arejado, tem umas seringueiras bem grandes. Era um seringal que foi desativado, as árvores têm até as marcas da extração do látex. Lá tem um parquinho onde eu brincava, onde os pais levam as crianças para brincar, e tem trilhas onde as pessoas ficam caminhando. Só que assim: o lugar está do mesmo jeito a mais de 20 anos, ninguém se preocupa em melhorá-lo. Ele é um lugar bonito porque foi obra da própria natureza, e não dos governantes desta cidade. Ia muito àquele parque na minha infância, ele tem um clima agradável que me faz esquecer os problemas, mas deve ter anos que não passo por lá, talvez porque me falte tempo e também pela distância, não é um lugar de fácil acesso.

Acho que sou movido à pilha, que não sou muito bom para falar assim, livremente, preciso de questionamentos. Contar as experiências de vida da gente não é uma coisa que estamos acostumados a fazer, que faz parte da nossa rotina, mas acho interessante, acho bom e essa narrativa foi um pouquinho da minha história. 


\section{Marcelo}

\section{"Encaro todas as dificuldades pelas quais passei como lição de vida"}

Nasci em sete de Julho de 1972, na cidade de Presidente Prudente, Estado de São Paulo. Morei em Martinópolis, Pirapozinho e Araçatuba, isso no Estado de São Paulo e aí me mudei junto com minha família, com pai e mãe, para Cuiabá, no Mato Grosso. Lá tive um irmão, que nasceu dia 25 de Junho de 1980.

Depois de 12 anos vivendo em Cuiabá, fomos para Campo Grande, no Mato Grosso do Sul. Ficamos 14 anos morando em Campo Grande. Por último, viemos para o Estado de Rondônia: meu pai, meu irmão e eu. Minha mãe faleceu quando morávamos em Campo Grande.

Estamos até hoje aqui, já faz 14 anos e pretendemos continuar, para fazer nossa história nesse lugar.

De todos os lugares por onde passei, onde morei, o que mais me marcou foi Campo Grande. Cheguei lá com 11 para 12 anos e saí com 22, 23 anos, por aí. Lá eu tive um aprendizado grande, um aprendizado com a vida. Para esclarecer isso, vou falar um pouco sobre meus pais.

Minha mãe tinha um problema de saúde. Ela foi criada no sítio e a família dela diz que esse problema foi ocasionado por causa de verme de carne de porco que ela comeu e foi para a cabeça. Outros dizem que era um câncer. Não sei, só sei que ela tinha muita dor de cabeça, chegava a desmaiar. Fez tratamento, meu pai a levou para São Paulo para fazer exame, ela tentou de tudo: fez até uma operação espiritual, no Estado de Goiás. Em 1989 faleceu, vítima desse problema. Eu estava com 17 anos. Foi uma tristeza imensa, mas tivemos que continuar tocando a vida.

Doze meses depois da morte de minha mãe meu pai se acidentou. Pulou numa piscina, na festa de despedida de solteiro de um primo meu e não sei se bateu a cabeça em baixo... Fraturou a coluna e ficou sem o movimento do pescoço para baixo. Com o passar do tempo e com os tratamentos, recuperou os movimentos da cintura para cima, mas continuou paraplégico. Nunca mais andou. Eu tinha 17 anos quando minha mãe faleceu, depois completei 18 e meu pai se acidentou. Fiquei um ano ou mais cuidando do meu irmão sozinho, tocando o escritório de contabilidade do meu pai sozinho, tocando as coisas. Meu pai era técnico em contabilidade. Ficou uns dois anos fora, fazendo tratamento, depois voltou e de cadeira de rodas continuou trabalhando no escritório. Continuamos trabalhando juntos.

Minha avó, mãe do meu pai foi para Campo Grande cuidar dele, antes de virmos para cá, e eu cuidei tanto dele quanto da minha mãe, quando ela estava doente. 
Meu irmão era pequeno, criança, só do meu pai, já aqui em Rondônia, que ele ajudou a cuidar, participou mais. Meu pai faleceu aqui em Porto Velho. Cuidei muito dos dois, tive que auxiliar, e não foi fácil não. Antes disso, a gente via as coisas acontecerem nas outras famílias: “ah, o pai de fulano está doente, a mãe doente, o avô doente...” e eu imaginava: “Isso nunca vai acontecer comigo, nunca vai acontecer com a minha família”, e pelo contrário: aconteceu tudo comigo!

Apesar de ser bastante jovem na época, acho que desempenhei muito bem meu papel de filho mais velho. Cuidei dos meus pais, trabalhei um ano sozinho para sustentar meu irmão, pagar as contas e tudo o mais. Não era fácil, eu era menino, menino às vezes tem sonhos, tem outras coisas na cabeça, e eu tive que parar para pensar só na família. Fiz coisas erradas? Fiz, todo mundo faz na adolescência. O ser humano está aí para errar, ninguém é perfeito, mas abri mão de muita coisa, por exemplo, a praia. Não conheço praia, não conheço mar. Tive muita oportunidade de ir, mas porque tinha que trabalhar, não podia sair, não podia viajar. Eu tinha aquela responsabilidade, entendeu? “Ah, vamos viajar!”

Os parentes que eu tinha lá na época, que eram bem de vida me chamavam para viajar, se ofereciam para pagar todas as minhas despesas, mas eu não podia ir porque tinha que trabalhar, não podia deixar meu pai sozinho no escritório. Não ia, não brigava com meu pai por causa disso. Hoje tiro tudo isso como experiência de vida. Não desejo isso a ninguém, mas todo mundo está sujeito. Graças a Deus, de certa forma sou feliz. Tenho saúde, posso trabalhar e tocar minha vida.

Depois viemos para Porto Velho, através de uma tia, irmã do meu pai, que já morava aqui. Ela nos trouxe para ficar mais fácil de ela cuidar da gente, nos orientar. Minha tia mora aqui há quase 20 anos. Depois que minha mãe faleceu, ela foi a grande responsável em "ocupar” o lugar dela, digamos assim. Ela é uma mãe para a gente e para toda a minha família. É dentista e é nosso ponto de referência para tudo o que precisarmos, para qualquer situação. Nosso refúgio é na casa dela. Foi essa tia que estudou meu irmão e que me formou, que me deu a faculdade. Ela cuida também de dois primos meus, cria-os desde pequenos, tanto é que eles a chamam de mãe. Foi casada, mas não tem filhos dela.

Tia Joaquina é nosso porto seguro aqui. Uma pessoa muito dedicada à família, muito caridosa, muito boa mesmo. Depois que me separei, que voltei de Vilhena, morei com ela uns dois anos, depois morei com meu irmão, aí ele casou e fui morar sozinho.

Trabalhei com meu pai sempre, em escritório. Só quando viemos para Rondônia que fui trabalhar fora. Naquela época ele não podia mais trabalhar, então tive que ir trabalhar fora. Agora estou trabalhando na área de venda de alimentos. Sou formado em Contabilidade, mas não 
exerço a profissão de contador. Meu irmão também mora aqui e é advogado. Esse sim exerce a profissão e já constituiu família.

Tenho uma sobrinha, é a coisa mais linda do mundo! O nome dela é Maria Clara e se não me engano, tem cinco aninhos. Meu irmão e minha cunhada, que hoje estão casados, se conheceram aqui em Rondônia, na escola Maria Auxiliadora, onde estudavam quando eram adolescentes. Minha cunhada sempre foi apaixonada pelo meu irmão, gosta muito dele e conseguiu! Namoraram na juventude, quando eram bem novos, depois na maioridade. Quando ela ficou grávida, não estavam namorando, só ficavam de vez em quando, mas ela sempre foi fixada nele, sempre gostou dele, ia atrás. Não que meu irmão não estivesse nem aí para ela, mas é que era jovem demais e não pensava em compromisso sério naquele momento.

Quando me casei eles foram ao meu casamento, eram novinhos, um casalzinho de namoradinhos. O tempo passou e sei que meu irmão aprendeu a cantar, tocar violão e por sinal, não é porque é meu irmão que estou falando isso, mas ele canta muito bem! Depois de terminarem o namoro cada um foi para o seu lado, nas idas e vindas da vida ficavam juntos de vez em quando e ela engravidou. Depois que a minha sobrinha nasceu, que já tinha uns dois ou três anos foi que voltaram de vez. Ele assumiu a responsabilidade, se casaram e estão vivendo muito bem, graças a Deus. Tenho que tirar o chapéu para a minha cunhada, porque ela foi persistente! Vamos ver se a Camila vai ter a mesma paciência em relação a mim. Estamos juntos há oito meses. Começamos a namorar dia 22 de Dezembro, já deu tempo de a gente se conhecer. Torço para que dê certo, para que a gente seja feliz.

Já fui casado, não deu certo, mas apesar disso quero sim constituir família, possivelmente com a Camila. Penso em ter um filho, um já está de bom tamanho porque é complicado ter filho hoje. Envolve muita coisa, criação... O mundo hoje está diferente demais, mudou muito e educar está difícil. Recebi uma educação muito rígida. Meu pai só precisava olhar para eu saber que tinha que ficar na minha. Mas fora isso, recebi deles muito amor e carinho. Eles me ensinaram a ter caráter, que acho muito importante. Acho bom termos uma formação de princípios, ser bem educado, porque o resto a gente adquire com a vida.

Sempre me relacionei bem com meus pais e me relaciono bem com meu irmão até hoje, temos um relacionamento muito bom por sinal. Nunca brigamos! Nunca aconteceu nada que nos separasse, até hoje somos bem unidos.

Nossa infância foi muito tranqüila. Brincávamos muito, de vez em quando fazíamos umas artezinhas, porque faz parte. A gente jogava futebol, brincava de esconde-esconde, polícia e ladrão, bétis, vôlei. Brincávamos até de carrinho. Quando chovia muito a gente amarrava uma linha nos carrinhos e saía puxando pelas poças d’água. Essas coisas de criança... 
Hoje gosto de assistir futebol, fórmula um, vôlei. De vez em quando a gente fica meio triste porque as coisas, no mundo esportivo, não vão do jeito que a gente quer, mas gosto de assistir. Não pratico esporte, mas já joguei muita bola, hoje estou fora de forma.

Nossa alimentação era normal: arroz, feijão. Éramos acostumados a levantar de manhã, tomar café, comer pelo menos um pão com manteiga. Almoçávamos arroz e feijão normal, jantávamos normalmente. Quem cozinhava era minha mãe, e muito bem por sinal! Fazia um doce de caju que nunca vi ninguém fazer igual. De caju, de goiaba... Agora de caju ela era professora.

Quando eu era pequeno, comprar um presunto, comprar um queijo e até uma coca-cola era um luxo. Quando tinha isso a gente comia e parece que era uma festa! Hoje o negócio ficou mais fácil, todo mundo pode comer um presunto, tomar uma coca-cola, comer um doce diferente. Quando me mudei para cá vi mais facilidade nessa área, mais facilidade para comer essas coisas, tanto é que fiquei mais forte, ganhei alguns quilinhos. Não que antes passasse fome, nunca passei fome, graças a Deus! Mas era uma alimentação diferenciada da que tenho hoje.

Gosto de todo tipo de comida. Das regionais aprecio vatapá, galinha picante, peixe, que é muito bom. Quando estou em casa gosto de cozinhar, mas às vezes, quando estou sem tempo, faço um lanche, uma coisinha mais rápida. Não sei fazer muitos pratos, mas quebro um galho, fica gostoso.

Pretendo continuar morando aqui em Porto Velho porque aqui me parece que ainda tem muitas oportunidades, mas quando cheguei achava muito feio esse lugar e não queria ficar aqui não, tentei até voltar. Era uma cidade muito suja, fedia. Hoje ainda tem alguns lugares que cheiram mal, mas mudou muito. É uma cidade antiga, não tem infra-estrutura, mas está melhorando. Os políticos que estão aí hoje deveriam fazer alguma coisa porque a hora é agora. Se não fizerem agora a cidade vai ficar para trás. Mas tenho convicção que isso daqui vai ficar bom, vai melhorar bastante. Meu lugar preferido nesta cidade é o rio Madeira, um lugar bonito e não precisa pagar nada para vê-lo. Pretendo continuar por aqui, meu pensamento hoje é aqui. A respeito de família, quero dizer que já fui casado uma vez, fiquei três anos casado e me separei. Não tive filhos, me decepcionei bastante, mas nem por isso fujo da raia... Pretendo ter uma pessoa do meu lado que sonhe comigo, se não, não tem sentido nenhum a vida. 


\section{REFLEXÕES SOBRE A LEITURA EM HISTÓRIA ORAL}

Antes de começar a análise das narrativas lidas no capítulo anterior, gostaria de apresentar algumas reflexões sobre a leitura, a interpretação em história oral. Acredito que essas reflexões preliminares poderão esclarecer o tipo de leitura que farei a seguir e seu por que.

Como pudemos observar nas Considerações sobre os Procedimentos e nas Considerações sobre o Corpus Documental, o trabalho de Textualização e Transcriação das entrevistas conferem a elas o status de texto. De acordo com $\mathrm{Eco}^{47}$, todo texto, seja ele definido como estritamente literário ou comunicacional, é um estímulo que provoca uma resposta no leitor, e esta resposta, por sua vez, poder se dar de diferentes modos, revelar interpretações diferentes. Para o autor, em um de seus diálogos com Barthes ${ }^{48}$, o texto não é o "papel impresso”, a simples materialidade, ou o conjunto de signos, mas um “objeto” que a interpretação constrói na tentativa circular de validar-se naquilo que constitui.

O texto da história oral, elaborado a partir das experiências, da memória, dos desejos, das necessidades, das fantasias, das estratégias de contar de cada colaborador, é polifônico. Traz consigo não apenas a voz do narrador, mas por meio dela e através dela, as que ouviu em sua vida: a de seus antepassados, a de seus contemporâneos, e não só a voz, mas a forma de dizer, o jeito de dizer, o sotaque, as expressões, as gírias, as múltiplas temporalidades, imagens e fragmentos de imagens, olhares e visões de mundo, sons, impressões, crenças, interpretações, sensos éticos e estéticos. Esse texto é, portanto, aberto e multidimensional. Para ir além de suas dimensões visíveis, explícitas, é preciso mais de um movimento, de um desdobramento, de uma lógica, de um autor, de uma direção ${ }^{49}$.Para que fosse possível fazermos uma única leitura dessas narrações, seria preciso que elas fossem “planas”, “rasas”, e não um hipertexto. Que pensássemos no "singular” em vez do "plural”, que existisse uma única verdade, uma única realidade, uma única natureza, um único deus, ou seja, que nós não nos desvencilhássemos de nosso jeito ocidentalizado de ver o mundo.

É importante compreender que em um texto multidimensional, seus múltiplos elementos estão interligados por meio da leitura. De acordo com Caldas

“[...] um texto multidimensional conecta seus múltiplos elementos através da leitura, mas essas conexões não são objetivas, reais, palpáveis: não pertencem à narrativa, mas à

\footnotetext{
${ }^{47}$ ECO, Umberto. OS LIMITES DA INTERPRETAÇÃO. São Paulo, Perspectiva, 1995.

${ }^{48}$ BARTHES, Roland. CRÍTICA E VERDADE. São Paulo: Perspectiva, 1996.

${ }^{49}$ CALDAS, Alberto Lins. NAS ÁGUAS DO TEXTO: PALAVRA, EXPERIÊNCIA E LEITURA EM HISTÓRIA ORAL. Porto velho: Ed. EDUFRO, 2001, p. 158.
} 
leitura, a interpretação. É a leitura que multiplica e faz fluir o texto [...] sendo leitura viva, ele é possibilidade de fluir em múltiplas dimensões” ${ }^{\$ 0}$.

Estas múltiplas dimensões são características do texto de historia oral, e, por conseguinte, devem ser enfrentadas. Ao contrário do que muitos pensam, perceber um texto como aberto, polifônico, carregado de virtualidades, passível de infinitas interpretações, não significa que ele não possua limites e não coloque limites para sua leitura, assim como dizer que um texto é potencialmente sem fim não significa que todo o ato de interpretação possa ter um final venturoso. De acordo com Eco, “até mesmo o desconstrucionista mais radical aceita a idéia de que existem interpretações clamorosamente inaceitáveis”. ${ }^{51}$

O fato de um texto aberto, possibilitar um número infinito de leituras, não quer dizer que aquele que vai interpretá-lo possa fazer "qualquer leitura”, ou possa, por exemplo, fazê-lo dizer o que não diz, afirmar idéias que não sustenta em sua forma geral ou que lhe seriam contrárias. Os textos costumam dizer mais do que seus autores pretenderam/pensaram, e menos do que os leitores, com suas paixões, gostariam que eles dissessem. Frente a isso, algumas atitudes parecem necessárias quando nos propomos a fazer uma leitura/interpretação/análise coerente de um texto de história oral, a saber:

a) Tentar compreendê-lo como um todo, se concentrar nele, em seu significado social, em sua lógica interna e na mensagem que transmite.

b) Entender que é um elaborado não para um único destinatário, mas para uma coletividade. O colaborador que narra suas experiências sabe que sua história será lida/ouvida/conhecida/apreciada/interpretada por muitos em espaços diversos, e ele deseja isso, não narra apenas por narrar, não elabora discursivamente suas experiências para deixálas ocultas, mas para registrar sua memória e a de seu grupo, sua história, seus ensinamentos, sua cultura, portanto, podemos imaginar que dentre todos os possíveis leitores que ele imagina que tomarão conhecimento de suas experiências, tenha elegido pelo menos um modelo, um "leitor ideal” para quem narra. Descobrir quem/como é o leitor ideal de cada narrativa pode ser uma estratégia interessante para uma boa interpretação.

c) Por último, é necessário seguir as pistas e sugestões que o texto nos dá, mergulhar, experimentar/perseguir/testar idéias, metáforas, imagens, ver até onde elas vão e se são pertinentes, desdobrá-lo, relacioná-lo, cruzá-lo com outros textos, com seus pares, com os que vieram antes e depois dele, seguir seus fluxos, fruir.

\footnotetext{
${ }^{50}$ CALDAS, Alberto Lins. NAS ÁGUAS DO TEXTO. Porto Velho: EDUFRO, 2001.
}

${ }^{51}$ ECO, op. cit. 
O conjunto dos textos constituídos nesta pesquisa, e dos textos constituídos por outros, das teorias existentes, me colocaram em um impasse: de onde partir? Das teorias testadas, criticadas, aceitas pela Academia ou das histórias de vida das famílias que colaboraram comigo neste estudo. Decidi partir das histórias de vida de meus colaboradores, do que essas histórias dizem por que não quero que elas sejam vistas como um "acessório” da pesquisa, um “ornamento” ou algo que serve apenas para “exemplificar o que as teorias dizem”. Não se trata de uma aversão ao teórico - reconheço sua relevância- mas de um posicionamento ético, de uma escolha de valorizar a experiência de vida daqueles que trabalharam comigo ao longo de três anos e que permitiram que esse trabalho fosse feito desse modo. Depois de "tomar coragem”, de fazer essa escolha, me vi diante do conjunto das narrativas e a pergunta que fiz foi: o que essas narrativas dizem individualmente e coletivamente? O que elas trazem para a história? Na tentativa de responder a essas questões passamos a esboçar nossa leitura 


\section{ANÁLISE DAS NARRATIVAS}

O deslocamento que faremos em direção a interpretações elaboradas pela Geografia e Ciências Sociais não é algo que se impôs autonomamente, mas representa uma escolha dialógica requisitada pela própria práxis e por exigências internas das narrativas. Reconhecemos, como destacou Braudel, que cada uma das ciências humanas "sonha, de fato, em manter-se nos seus domínios ou voltar-se a eles” ${ }^{52}$, assim como reconhecemos a necessidade de diálogo entre elas e que História e Ciências Sociais se encontram, desde há muito tempo, em “zona de litígio" 53. Desta forma, nos aproximamos de teóricos da Geografia como Henri Lefebvre, Milton Santos e Paulo César da Costa Gomes, que atualizaram a discussão do mestre francês para as realidades brasileiras e de cientistas sociais como Zigmunt Bauman, Lúcio Kowarick e Eva Alterman Blay. As reflexões históricas encontraram suporte em uma tradição historiográfica cujos trabalhos não se limitam à cronologia linear, mas assinalam variações e recorrências. Nesse rol encontram-se Marc Bloch, Jacques Le Goff, Pierre Nora, e mais perto de nós, historiadores como Caio Prado Júnior e Zilda Iokoi.

As leituras e interpretações que construímos tiveram como ponto de partida as narrativas de nossos colaboradores dispostas em séries. A partir delas procuramos verificar regularidades, causalidades e sistemas de relações. Concentramos nossa atenção nos elementos que marcam a "memória coletiva” desse grupo, nos elementos que se repetem.

Optamos por estudar traços da memória coletiva porque entendemos que ela tem algo a nos ensinar. É a condição da inserção dos indivíduos no espaço e no tempo, uma percepção do “agora” que se situa entre o passado e o presente, capaz de tornar possível a ação individual responsável - aquela que tem por finalidade a defesa do bem comum ${ }^{54}$

Vivemos em um tempo onde o cuidado com o bem comum tem sido negligenciado, as ações cada vez mais individuais e individualistas e no qual parece vigorar uma histeria coletiva que reflete o medo da “perda da memória”. Frente à ameaça de doenças da memória como amnésias e mal de Alzheimer e do esquecimento, deformação e apagamento - sintomas de um afastamento da experiência -, passa-se a registrar tudo, com ou sem critério. Os indivíduos fotografam incontáveis cenas da vida cotidiana, escrevem diários e blogs, distribuem pelas casas bilhetes datados direcionados a si próprios, para serem lidos no futuro e “orientarem” a memória, ou favorecer sua reinvenção; e mais que isso, empresas, gestores públicos e prefeituras parecem estar na “febre da memória”, registrando suas experiências, provavelmente preocupados mais

\footnotetext{
${ }^{52}$ BRAUDEL. Fernand. A LONGA DURAÇÃO. In: História e Ciências Sociais. Lisboa: Ed. Presença, 1986.

${ }^{53}$ A esse respeito ver SILVA, Fernando Teixeira da. HISTÓRIA E CIÊNCIAS SOCIAIS: ZONA DE FRONTEIRA. In: http://www.scielo.br/pdf/his/v24n1/a06v24n1.pdf

${ }^{54}$ ARENDT, Hannah. ENTRE O PASSADO E O FUTURO. São Paulo: Ed. Perspectiva, 2005.
} 
consigo do que com a posteridade. E não se trata de um simples problema individual, referente a uma memória fisiológica passível de patologias, mas ele próprio é reflexo de uma memória coletiva, na qual a consciência é determinada por quadros sociais que a antecedem ${ }^{55}$. Myriam Santos afirma que as relações entre memória e sociedade têm se ampliado ao longo do tempo e ao abordá-la enquanto aprendizado, acúmulo de conhecimento e transmissora do mesmo, problematiza:

Podemos dizer que a memória, enquanto aprendizado, se perde no mundo da informação. A partir da substituição do artesão pelo operário de fábrica, o trabalho se reduz a atos mecânicos e repetitivos sem que seja necessário para o desenvolvimento das atividades previstas o aprendizado acumulado durante a vida. O tempo se desvincula das experiências de vida, tornase autônomo, regulado, impessoal, e passa a exercer controle sobre os passos de cada um. ${ }^{56}$

Difícil analisar nosso próprio tempo, nosso mundo informatizado, automatizado, principalmente, porque estamos no ponto mais elevado (até o momento) do processo de substituição do “artesão pelo operário”, que ganhou destaque a partir da Revolução Industrial inglesa. Não temos o distanciamento temporal conveniente para tecer (digitar) uma análise segura dessa problemática, e como não queremos estudar apenas “problemas distantes” que já foram magistralmente analisados por outros, só temos uma saída: procurar quem queria narrar, compartilhar suas experiências, ainda que em fragmentos, procurar quem tenha uma história para contar e ver o que ela traz de coletivo, mesmo que isso pareça anacrônico.

\section{Do que falam os textos}

Sem entrar no mérito dos significados ocultos, das intenções psicológicas, o conjunto das narrativas falam da vida. Da vida em Porto Velho, uma cidade no interior da Amazônia, da vida em São Paulo, em Itapecerica da Serra. Da vida no nordeste, no norte, no sudeste:

[...] fui para o Piaú́, e foi muito legal. Lá eu ficava matando pomba, rolinha, preá, era da hora! Tenho vontade de voltar para lá, hora que minha mãe decidir ir, vou atrás! (Cássio)

Rondônia é um Estado muito rico em produção. Tem agricultura, tem pecuária, tem garimpos, e mesmo assim tudo aqui é bagunçado porque os políticos são ruins e os cidadãos também não se importam muito, não cobram. (Caio)

\footnotetext{
${ }^{55}$ HALBWACHS, Maurice. A MEMÓRIA COLETIVA. São Paulo: Ed. Vértice, 1990.

${ }^{56}$ SANTOS, Myrian Sepúlveda. MEMÓRIA COLETIVA E TEORIA SOCIAL. Rio de Janeiro: Ed. Annablume, 2002.
} 
Aqui ${ }^{57}$ também tem bastante opção, mas o tempo é mais curto. Você tem que correr, resolver um assunto de trabalho aqui, outro ali, acaba perdendo o dia. Meu dia aqui é só para resolver assunto de trabalho e mais nada, mas quando estou viajando gosto de ir a muitos lugares desbravar, revirar a cidade de cabeça para baixo. (Filipe)

Falam da vida do trabalhador, do desempregado, dos pais, dos filhos, da vida da maior parte dos brasileiros. São histórias de gente comum, que ama, briga, trabalha, pega ônibus, cria filhos, cozinha, luta para ter uma casa:

Quero ter minha própria casa para não ter que ficar de um lado para o outro. Por mais que seja sua mãe, sua avó, você não é mais criança, já sabe o que quer para sua vida e não se sente à vontade em estar dependendo das pessoas [...] (Carolina).

O que estamos atrás é de uma moradia, não é de luxo, de mansão, de apartamento chique. Queremos simplesmente um lugar para viver. É necessário, todo ser humano precisa de uma moradia. (Maria da Paixão).

Fui participar da ocupação Chico Mendes pela necessidade de ter uma casa. Sou casado, minha esposa e eu vamos ter um filho. A gente se casou e ainda não tem onde morar, pagamos aluguel e é difícil, é apertado. Hoje em dia é muito difícil conseguir uma casa. (Caio).

O tempo que passamos no Valo Velho foi muito difícil, muitas vezes não tínhamos nem comida. A gente não tinha nada, nada, nada! Somente nossas roupas, então saíamos fazer o "corre", procurávamos pessoas para nos apoiar [...]Chegávamos já eram duas, duas e pouco da manhã, com um monte de bolsa, um monte de coisas. Íamos a pé de lá do Capão Redondo até o Valo Velho porque não tínhamos dinheiro para a condução. Foi uma época muito difícil e a Lady dizia: “Ai Laura, a gente tem que ganhar essa casa porque já não agüento mais andar!” (Laura).

Nossa casa vai ser uma vitória linda, um troféu como nunca ninguém jamais teve, e não vai ser um troféu para ficar guardado, vai ser um troféu para ser utilizado pelos nossos filhos, netos, bisnetos. [...] Quando tiver um filho ele vai ter que lutar também, vai saber a história do lugar onde vive, como consegui a casa dele. (Bárbara).

Essas histórias falam da vida vivida, da luta diária, dos problemas da cidade, e falam também da vida sonhada, das utopias, da complexidade dos desejos, vontades, intenções:

${ }^{57}$ São Paulo. 
Desde pequena tenho vontade de ter mais tempo para poder estudar, porque gosto muito de estudar e queria me formar professora. Meu sonho é aprender a tocar violão. [...]Então meu sonho é aprender a tocar guitarra e voltar para lás8 . (Luana).

Minha intenção maior é essa: conseguir um terreno, construir uma casa para poder constituir minha família. (Junior).

[...] quero que minhas netas sejam como eu: trabalhadeiras, lutadoras, de uma moda sem prejudicar ninguém, honestas, decentes, pobres, mas dignas, porque acho que o mais importante é você ter dignidade. (Maria da Paixão).

Quero acreditar que todo mundo é capaz de cada vez mais querer ardentemente mudar o mundo, e que todo mundo é capaz cada vez mais de construir a própria vida neste sentido. Não é abrir mão da vida ou de certo tipo de vida, é querer ter um outro. (Ana Terra).

Mas também falam da morte, da que é natural, encerramento do ciclo da vida, e da “morte matada”, ou melhor, da "vida matável”, da "vida nua”, desprovida de direitos, tal qual problematizou Agambem ${ }^{59}$. Como exemplos do primeiro caso, temos trechos das entrevistas de Marcelo e Paixão, e como exemplo do segundo, um excerto da narrativa da Carla:

Minha mãe tinha um problema de saúde. Ela foi criada no sítio e a família dela diz que esse problema foi ocasionado por causa de verme de carne de porco que ela comeu e foi para a cabeça. Outros dizem que era um câncer. Não sei, só sei que ela tinha muita dor de cabeça, chegava a desmaiar. Fez tratamento, meu pai a levou para São Paulo para fazer exame, ela tentou de tudo: fez até uma operação espiritual, no Estado de Goiás. Em 1989 faleceu, vítima desse problema. (Marcelo).

É uma pena que perdi a minha mãe, vai fazer três anos. Mas é essa a vida, isso faz parte. Há três anos foi ela, depois vai ser outro, daqui a 10, 15 anos não sei, vai ser eu, vai ser nós, mas uma coisa eu digo: quando eu faltar nessa terra quero que meus filhos, meus netos e até a minha quarta geração... Não quero que falem: “minha avó, minha mãe, foi uma pessoa inútil”. (Maria da Paixão).

O Estado trazia as pessoas como trazia animais, sem a menor condição de vida. [...] Percebo que as pessoas que vieram na época da Segunda Guerra, vieram praticamente como escravas, porque morreram sem direito a nada, sem direito a sequer um funeral digno. Morte injusta diante de todo o esforço que fizeram. Os mortos eram enrolados em lençóis e enterrados na beira das estradas ou na margem dos rios. A gente cresceu vendo isso. (Carla).

\footnotetext{
${ }^{58}$ Para o Piauí.

59 AGAMBEM, Giorgio. Homo Sacer: O PODER SOBERANO E A VIDA NUA. Belo Horizonte: Ed. UFMG, 2004.
} 
Traçam a cartografia de suas trajetórias: de onde vieram, para onde gostariam de ir e onde gostariam de permanecer:

Morei em Martinópolis, Piraposinho e Araçatuba, isso no Estado de São Paulo e aí me desloquei junto com minha família, com pai e mãe, para Cuiabá, no Mato Grosso. [...] Depois de 12 anos vivendo em Cuiabá, fomos para Campo Grande, no Mato Grosso do Sul. Ficamos 14 anos morando em Campo Grande. Por último, viemos para o Estado de Rondônia. [...] De todos os lugares por onde passei, onde morei, o que mais me marcou foi Campo Grande. (Marcelo)

Não posso dizer que gosto daqui, primeiro porque cheguei faz pouco tempo, segundo porque aqui a vida é muito difícil e tem todos os problemas que você pode imaginar. Ontem mesmo a Laura falou: “Vamos para o Piauí?”, e eu disse: “bora! Se eu começar a trabalhar vou juntar dinheiro e vamos para lá”. (Cássio).

Sou índia, nunca saí daqui, só conheço Porto Velho e alguns de seus distritos, então não tenho uma cidade preferida. Ao contrário de meus irmãos, nunca viajei, não conheço nenhuma metrópole. Sou a índia da Amazônia. (Carolina)

Nasci aqui em Porto Velho em 19 de Outubro de 1985, vivi um tempo aqui, um tempo no Ceará, onde meu pai nasceu e um tempo em Ariquemes, acho que uns três, quatro anos. Para o Ceará a gente ia constantemente porque meu pai tinha uma fazenda lá. Ele vivia viajando e às vezes levava a gente, depois trazia de volta. (Junior).

Estamos até hoje aqui, já faz 14 anos e pretendemos continuar, para fazer nossa história nesse lugar. (Marcelo, falando sobre Porto Velho).

As narrativas expressam uma cartografia subjetiva, mapas da memória dos colaboradores, tonalizados na dimensão do vivido, mas se o leitor sentir necessidade de uma visualização "mais material” dos espaços abrangidos pelas experiências de vida das famílias entrevistadas, poderá consultar o material cartográfico apresentado nos anexos, bem como informações sobre as fotografias.

O que essas narrativas trazem de coletivo, o que se repete, são as lembranças da infância, dos pais, a escola, as mudanças na alimentação, o desejo de ter casa e a cidade, seja aquela onde se vive, apresentada em seus aspectos problemáticos ou com ênfase a seus lugares agradáveis, seja a cidade em que se viveu. Desses elementos que marcam coletivamente as narrativas extraí o tema deste estudo. Mas antes de passarmos a uma reflexão mais aprofundada sobre eles, gostaria de assinalar alguns dos elementos da memória coletiva, expressos nos textos das famílias colaboradoras. 


\section{Recordações sobre a Infância:}

Outra coisa que aprecio além da bateria e do estudo é desenho, mas agora é como se eu estivesse fora de forma, acima do peso, porque não tenho tempo de exercitar, de me aperfeiçoar, mas quando tinha por volta de seis, sete anos eu desenhava muito, acho que o meu dia inteiro. Desenhava muitas coisas, inclusive as figurinhas do Looney Tunes e tinha uma pasta onde deixava os meus desenhos guardados, aí do nada parei, minha rotina de vida foi mudando, esqueci o desenho, deixei para lá. (Filipe).

Uma vez lá no Menininha teve uma ocupação da qual participei e me lembro claramente. Todo aquele povo que mora lá hoje é da época dessa ocupação. Eu tinha entre oito e nove anos, minha mãe trabalhava muito e mandou um homem construir um barraco para a gente, deu um temporal e o barraco caiu, porque era em um morro, nem deu tempo de tirar as coisas, foi geladeira, fogão, roupa, foi tudo. Só deu tempo de ela nos tirar, as coisas ficaram na lama, na inundação. (Laura)

Quando eu era criança o que mais gostava de fazer era soltar pipa. Esta sempre foi minha brincadeira preferida. Soltava muita pipa, quebrava laje alheia, telha dos outros, tudo por causa de pipa. Não só empinava como saía correndo para apanhar as que eram cortadas, só faltava perder os dedos no meio da avenida. Bola eu joguei pouco, mas teve um tempo em que desejei ser jogador de futebol, goleiro, porque gosto mais de defender. Brincava de muitas coisas na minha infância, só não brincava de boneca. Boneca era brinquedo para minhas irmãs. (Cássio)

Minha infância foi bacana, não foi infância de criança triste, sofrida. Meu irmão e eu vivíamos 24 horas na rua empinando papagaio e jogando peteca. Para estudar era um sacrifício, minha mãe tinha que chegar do trabalho e correr atrás da gente, colocar a gente para dentro de casa para tomar banho e ir para a escola. Muitas vezes eu inventava que estava com dor de cabeça ou então, quando ela ligava para saber se a gente tinha ido eu dizia que estava chovendo, e ia brincar. [...] Uma vez passou um menino por mim, de bicicleta - era um colega nosso - aí eu sentei um tapa nas costas dele, e falei: “Ei colega!” Sentei um tapa que ficou marcado, vermelho, aí a mãe dele foi lá em casa brigar. (Carolina).

Era de praxe, a gente chegava da escola, às vezes não dava nem tempo de tirar o uniforme já chegava o Bernardo, o Paulo, o Marcos, já chegavam as crianças para brincar com o Igor. E era sempre na minha casa, que era uma casa que tinha um terreno com bem pouca estrutura. Não tinha churrasqueira, não tinha piscina, não tinha nada, mas era todo cheio de árvores e a gente pendurava cordas nas árvores. Igor e eu inventávamos as nossas brincadeiras e os nossos brinquedos com os recursos que a gente tinha. Praticamente não comprávamos brinquedos, e construí-los também não era algo muito racional... Era da ordem de usar os recursos, mexer nas coisas e criar possibilidades de brincar. Tenho uma foto da gente fazendo malabarismo, várias brincadeiras na piscina com nossos amigos. Eles tinham piscinas, mas quem ia lá e inventava as brincadeiras mais legais era a gente. (Ana Terra). 
Minha infância foi como a de muitas crianças: brincar, se divertir, estudar, sair com a família. Tive uma família maravilhosa, bom pai, boa mãe, irmãos excelentes.

Brincava de boneca, de casinha, de moda. Vestia as roupas da minha mãe, calçava os sapatos de salto dela e saía desfilando pela casa. Já os meus irmãos iam para rua, empinar papagaio. Eu ficava em casa, toda quietinha. Dia de chuva eles brincavam lá fora e eu ficava em casa, quietinha, assistindo desenho animado. (Camila)

Na minha infância tive muitos amigos, tanto na Vila, onde morava com meus pais, quanto no Centro, onde morava com minha avó. Brincava muito na rua, jogava bola, empinava papagaio, jogava peteca, bolinha de gudi, mas era meio regrado porque minha mãe era muito preocupada e rígida com a questão de horário. Não podíamos ficar brincando até tarde na rua. (Caio).

Na minha infância eu fazia estradinha em frente de casa, na areia, e brincava com tampinha de garrafa, fazia corrida de tampinhas de garrafa, brincava de fazer estilingue com liga de pneu para brincar com as tampinhas, brincava com muita coisa, brincava de futebol, de carrinho, de esconde-esconde e aquelas brincadeiras todas da infância. A Patrícia estava sempre junto nas brincadeiras e as meninas da rua também, as meninas e os meninos. Tinha vezes que elas jogavam bola com a gente. (Junior).

Nossa infância foi muito tranqüila. Brincávamos muito, de vez em quando fazíamos umas artezinhas, porque faz parte. A gente jogava futebol, brincava de esconde-esconde, polícia e ladrão, betis, vôlei. Brincávamos até de carrinho. Quando chovia muito a gente amarrava uma linha nos carrinhos e saía puxando pelas poças d’água. Essas coisas de criança. (Marcelo).

\section{Recordações sobre os Pais:}

Meu pai contava muitas histórias, ficcionais e verdadeiras, e foram esses momentos de ouvir as histórias narradas por ele que mais me marcaram. [...] Penso que meu pai foi um guerreiro vencedor, por ter conseguido superar todas as barreiras, ter conseguido construir família e formar os filhos, mas não conseguiu usufruir as conquistas dessa batalha. [...] A história de como meu pai chegou, de como conheceu minha mãe e de como construíram juntos uma família são coisas que marcaram minha história de vida. Vejo os dois como guerreiros que batalharam e conseguiram vencer... (Carla).

[...] meu pai criou a nós todos trabalhando na roça. [...] Meu pai tinha um rádio velho, bem grande, que era ligado todos os dias às seis horas da tarde para a gente "assistir" a reza. [...] Depois ele desligava, acendia uma fogueira lá fora e ali era a nossa convivência de todos os dias. [...] O meu pai, coitado... Lembro que a melhor roupa dele - que era de vestir para ir para a cidade - era uma camisa, só que do tecido dela mesmo havia bem pouco. Tinha vários e vários pedaços de outros panos que minha mãe colocava, vários remendos. Ele vestia aquela roupa e 
recebia muita crítica porque a família da minha mãe era melhor de vida. Criticavam minha mãe por ter se casado com meu pai. Meu pai era pobrezinho, vivia naquela situação e eles humilhavam muito a gente por causa disso.

[...] Minha mãe lavava aquela roupa para meu pai, aquela calça com um milhão de remendos, coitado, do tecido da calça só tinha mesmo o corredor e a costura, o resto era só remendo. (Maria da Paixão).

Minha mãe tinha que chegar do trabalho e correr atrás da gente, colocar a gente para dentro de casa para tomar banho e ir para a escola. [...] Minha mãe ia trabalhar e deixava a gente sozinha.

[...] Recordo que meu pai saia para trabalhar seis horas da manhã, nos acordava, muitas vezes nos colocava ainda dormindo dentro do carro e largava a gente aqui na casa da mamãe. Aqui a gente tomava café, almoçava, daqui ia para a escola, da escola vinha para cá de novo, e só de madrugada, umas três horas da manhã que meu pai buscava a gente e levava para casa. Fomos criados mais na casa da minha avó do que na nossa casa... (Carolina).

[...] Todas essas frutas tem no sítio do meu pai e vou lá com freqüência: uma vez por semana, às vezes duas vezes por mês, três, dependendo das folgas dele, porque não é todo dia que ele está em casa. Faz um serviço aqui, um serviço ali, só esse mês agora ele está com três serviços para fazer, ele trabalha de pedreiro. Está terminando um serviço, já vai entrar em outro, e depois no outro, e assim vai, não tem previdência para ele estar em casa. É muito difícil encontra-lo em casa num sábado ou num domingo. (Luana).

Meu pai morou comigo até quando eu tinha dois, três anos, aí minha mãe deu uma surra nele e ele foi embora e não voltou mais. Deu uma surra porque ele tentou bater nela. Depois disso, só voltei a ter contato com ele quando já estava com meus 12, 13 anos, por aí. Não lembro de nada dele, ele nunca morou comigo, não teve participação em nada. Minha mãe fez o papel dos dois, foi mãe e pai um bom tempo, até meu padrasto aparecer, tanto que o chamo de pai hoje. (Filipe).

Em menos de cinco minutos foi avisado no alto-falante: "Laura, sua mãe ta aí fora, ela mandou dizer que ou você sai, ou ela entra”. Pensei comigo, ela vai entrar pela porta da frente e eu escapo pela dos fundos, chegando em casa a gente resolve isso, mas não vou passar vergonha na frente dos meus amigos nem na frente de estranhos, só que quando eu estava saindo ela estava me esperando, perto de umas motos. [...] Minha mãe não teve escrúpulo e me bateu até chegar em casa.

[...] Um dia cheguei a perguntar para a minha mãe se ele era mesmo meu pai, ela garantiu que sim. Fui conhecendo-o pouco a pouco, mas nunca gostei dele por causa do jeito de ele me tratar. Se ele me tratasse com amor da mesma forma iria tratá-lo, só que não, sempre fui rejeitada.

\section{Recordações sobre a Escola:}

Eu tinha muitos amigos, era bem sociável, tanto no bairro quanto na escola. Gostava muito de estudar, cheguei a ser líder de classe e líder religioso - estudei em uma escola salesiana - então 
tinha eleições para líder de classe e líder religioso, e cheguei a ser os dois ao mesmo tempo, porque era dedicado aos estudos e me dava bem com os colegas. (Caio).

Lá no norte, quando a gente ia para a escola bagunçava muito! Eu gostava muito de bagunçar, a única coisa que não gostava de fazer era Educação Física, não gosto até hoje. As aulas que eu mais prestava atenção eram as de Matemática e História, mas éramos pequenos, não conseguíamos prestar atenção direito, ficávamos brincando, tinha vezes que tinha até briga dentro da sala, um ficava chutando o outro. Estudei a primeira série aqui, a segunda e a terceira lá. Eu era pequena. [...] Lá no Norte é um professor só por turma, que ensina Português, Matemática, História, Ciências... Só não Inglês, porque Inglês é depois da quinta série, e esse professor era meu cunhado, era muita bagunça! (Luana).

Do tempo de escola, nossa, não gosto nem de falar! Este ano minha mãe me matriculou, estou matriculado, mas ainda não fui para a aula um só dia sequer. Não sou muito de ir para a escola não, mas quando ia aprontava demais, os professores faltavam morrer. E o professor Pedro então! Mandou que me levassem para a roça porque não me suportava mais. Chegaram a me amarrar em uma mesa porque não me agüentavam mais na escola. Foi muito engraçado! A única matéria que eu gostava era Educação Física, que consistia em ir para a quadra jogar bola. [...] a escola de lá ${ }^{60}$ é ótima, muito melhor do que as daqui. Você vê que é diferente, as salas de aula limpinhas, o pessoal não rabisca as paredes, os professores são mais pacientes, até o sotaque é diferente. Lá eu gostava de estudar. Minha mãe falou que a escola na qual eu estudava lá é a mesma em que ela estudou quando era criança, só que foi toda reformada. (Cássio)

Até a oitava série estudei no Carmela Dutra, uma escola tradicional daqui de Porto Velho, antigamente uma escola só para meninas. Saí de lá por causa da idade. Acho que estava com dezesseis anos ainda na oitava série. Fui estudar no Padre Moretti, só que era muito distante da casa dos meus pais, então vim morar de vez aqui na casa da mamãe. Essa escola era supletiva, você fazia uma série em um semestre. (Carolina).

Estava estudando, mas tive que trancar minha matrícula por causa do trabalho. Trabalho com teatro, viajando de um lado para outro, de um lado para outro, então como é que vou estudar? Não tem como. O estudo agora é como se fosse uma refeição fora do cardápio, mas um dia pretendo continuar. Parei no segundo ano do Ensino Médio, faltava o terceiro, depois eu podia fazer alguma faculdade, mas o tempo agora não permite. (Filipe)

\section{Problemas e Virtudes da Cidade:}

Com relação à cidade, há que se dizer que Vinhedo mudou muito e acho que logo vai deixar de ser como é, porque as indústrias estão chegando e ela está se descaracterizando. Hoje é uma cidade meio turística, mas já está mudando. Tem muita gente começando a vender suas casas.

\footnotetext{
${ }^{60}$ Refere-se à escola onde estudou no Piauí.
} 
Os ricos vão vendê-las para comprar em outros lugares, porque pelo que estou vendo, Vinhedo vai ficar um lugar degradado, sua qualidade ambiental já está caindo... (Ana Terra)

Porto Velho é bom para se morar, para educar, porque aqui tem ótimas escolas, mas na parte da habitação e da saúde não está boa não, tem que dar uma melhorada grande. Se for depender da saúde pública muitas vezes a pessoa morre e nem sabe por que, como foi o caso de um amigo do meu pai, que morreu e ninguém soube a causa. (Junior).

No Chico Mendes havia aqueles prédios abandonados ao lado, mas não os ocupamos. Ele servia apenas para os crimes cometidos na cidade: desova de corpos, depósito de carros e motos roubadas, policiais matando pessoas inocentes que confundiam com criminosas, mendigos, eu mesmo já apanhei lá dentro, e deixo claro que não tenho passagem pela Polícia. (Marcos).

Os alugueis, em questão de pouco tempo aumentaram bastante e o preço das casas também. Hoje você não consegue comprar uma casa decente em Porto Velho por menos de R\$: 50.000. [...]Existe, em Porto Velho, um lugar que me é particularmente especial, um lugar de memória, porque o freqüentava muito quando era menino. Trata-se do Parque Circuito. Gosto de lá porque é bem arejado, tem umas seringueiras bem grandes. Era um seringal que foi desativado, as árvores têm até as marcas da extração do látex. Lá tem um parquinho onde eu brincava, onde os pais levam as crianças para brincar, e tem trilhas onde as pessoas ficam caminhando. Só que assim: o lugar está do mesmo jeito a mais de 20 anos, ninguém se preocupa em melhorá-lo. Ele é um lugar bonito porque foi obra da própria natureza, e não dos governantes desta cidade. (Caio)

O que a Marta fez me adiantou: um corredor de ônibus porque agora não pego mais tanto trânsito para ir trabalhar, mas o resto que eles estão fazendo, derrubando, medindo rua, construindo sei lá o que... Vão construir um mercado logo mais aí na frente, não é nada do meu interesse. Se eles estivessem fazendo casas: “A, vão derrubar a favela e construir casas, construir apartamentozinhos e dar para as pessoas”, seria uma coisa interessante, mas político não pensa em pobre, político pensa em dinheiro e no seu voto, é claro. (Filipe).

Quando apresentamos as histórias de vida na parte anterior, sob o título de "Narrativas de uma família de São Paulo” e “Narrativas de uma família de Porto Velho”, talvez o leitor tenha criado a expectativa de conhecer "dados objetivos" dessas cidades, de conhecê-la em seus aspectos geográficos, econômicos, demográficos, mas elas foram apresentadas de modo diferente pelos narradores - e não nos preocuparemos em transmitir esse tipo de informação, que pode ser encontrada em almanaques e sites diversos da internet. Falaremos das cidades da memória de nossos colaboradores e tentaremos compreendê-la na dimensão em que são tonalizadas nas narrativas. Para isso, a primeira coisa que precisamos entender é que a São Paulo, a Itapecerica da Serra e a Porto Velho dos colaboradores não são “cidades absolutas e unívocas”, mas cidades 
formadas por diversas experiências, urbanas e campestres. Assim, quando dizemos "narrativas de uma família de São Paulo”, esse “de” indica menos uma procedência do que uma necessidade do presente constructo verbal, necessidade de "localizar" territorialmente os colaboradores da pesquisa.

Os filhos de Maria da Paixão nasceram em São Paulo. De fato essa família vive em São Paulo e sua região metropolitana, mas ao falar desta cidade trazem também outras referências como as das cidades e campos nos quais viveram no nordeste no período que lá moraram. O mesmo ocorre com a família de Porto Velho, que apesar de se mostrar mais sedentária do que a família de Laura, possui ancestrais oriundos de outras experiências urbanas (Ceará, Mato Grosso). Neste texto chamado cidade é possível ler os sinais de variadas relações culturais, políticas, econômicas, sociais, de classe, de gênero, de luta por hegemonia. Polissêmico por excelência, nos desafia a todo o momento. É ao mesmo tempo esfinge e labirinto. Desafio e sedução. Com seus olhos pétreos nos diz: “Decifra-me ou devoro-te!”, e diante desse desafio, não temos outro caminho senão percorrê-la e adentrar em seus labirintos de concreto e gente, de imagem e som, significante e significado.

As narrativas das duas famílias são convites a um passeio por cidades de suas memórias. Grandes e pequenas, encantadas ou sem encantos, acolhedoras ou violentas, amadas ou odiadas, essas cidades, mais do que um referente aos cenários onde desenvolvem suas histórias, é parte delas.

Chegamos até essas cidades mediante narrativas que possuem como matéria-prima a experiência, a memória e o sonho. São esses elementos que a constituem, e como cada narrador é um ser singular, utiliza esses elementos de uma maneira única, conforme mais lhe apraz ou conforme lhe é possível no momento da gravação da entrevista que registra esse seu momento discursivo.

Essas cidades da memória, ficcionais, matizadas pelo desejo, possuem substrato concreto, dado pela experiência. Se fossemos escavá-las tal como fazem os arqueólogos, encontraríamos sob sua superfície camadas e mais camadas de "cidades reais”, de cidades que existem enquanto modo de produção, luta de classe, ideologias políticas e urbanísticas, fluxo de pessoas e idéias, concreto armado, modernidade e tradição. Sabemos assim, que a Teresina de Maria da Paixão, a Campo Grande de Marcelo ou a Rio Branco do Caio não são as mesmas e não são iguais às cidades de mesmo nome e até de mesmas proporções dos mapas geopolíticos, embora as tenha como referencial.

Para Maria da Paixão, Teresina é mais que uma cidade, ou melhor, é uma cidade sem limites, pois compreende o Estado do Piauí inteiro, os campos, o sítio onde foi criada, o sertão das histórias que ouviu de seu pai, onde ele viveu e trabalhou na juventude, as ruas onde ela e a 
irmã, escondidas, pularam o Carnaval, o paraíso perdido, destruído pela serpente que picou sua mãe quando colhia os cachos de arroz. Esta cidade da memória de Maria da Paixão é sua origem, da qual não se envergonha, seu berço e o túmulo desejado para dormir o sono dos justos depois de cumprida a missão. Mais do que isso: é seu norte. É para onde toda a sua vida de trabalho em São Paulo se encaminhou, seu rumo certo, seu "porto seguro":

[...] a qualquer momento, qualquer dia que eu disser: “Quero ir embora para o norte”, tenho um lugar para morar, tenho um campo para cuidar, para eu trabalhar. Meu filho falou: "Mãe, porque a senhora não comprou uma casa aqui? Lá no norte é ruim, é seco, é isso, é aquilo”, mas eu não pretendo ficar aqui. Pretendo ir para a minha cidade, curtir minha velhice lá.

A Campo Grande apresentada por Marcelo é como a cidade conquistada pelo jovem guerreiro solitário, último sobrevivente de muitas batalhas. Lá travou suas lutas mais difíceis, viu se deteriorar a saúde das pessoas que mais amava, viu a mãe falecer, viu-se privado da liberdade de fazer as coisas típicas de menino e até de comer as guloseimas que lhe apeteciam. Condenado ao trabalho para garantir a própria sobrevivência, a do irmão pequeno e a do pai doente, Marcelo resiste estoicamente, cresce, torna-se homem e precocemente adquire a sabedoria que muitos só conquistam na velhice: aprende a tirar do sofrimento lições para a vida e a querer viver sempre mais, "tocar a diante".

Os parentes que eu tinha lá na época, que eram bem de vida me chamavam para viajar, se ofereciam para pagar todas as minhas despesas, mas eu não podia ir porque tinha que trabalhar, não podia deixar meu pai sozinho no escritório. Não ia, não brigava com meu pai por causa disso. Hoje tiro tudo isso como experiência de vida. Não desejo isso a ninguém, mas todo mundo está sujeito. Graças a Deus, de certa forma sou feliz. Tenho saúde, posso trabalhar e tocar minha vida.

A Rio Branco do Caio é antes de tudo seu sonho político, seu desejo para o país. Uma cidade modelo, exemplo de boa administração, de participação popular, de refinadas manifestações culturais, onde a cultura popular é expressa de forma autêntica. Cidade que conheceu de passagem, quando estava a trabalho, mas que seu olhar de viajante atento apreendeu em detalhes. Caio, ao retornar a Porto Velho, sua cidade natal, leva consigo esse ideal de cidade e a seu modo, luta por ele, com toda a convicção de quem crê que é possível construir um mundo melhor.

Assim como Maria da Paixão, Marcelo e Caio, os demais narradores também possuem uma visão e uma relação específica com suas cidades vividas-sonhadas. Ana Terra sente um “carinho geográfico” por Taboão da Serra, talvez por ter estudado a cidade, lido seus mapas, 
palmilhado toda a sua extensão enquanto lutava junto ao MTST. Apesar de perceber a estrutura excludente da cidade, os inúmeros problemas sociais que comporta e promove e entender seus processos de especulação imobiliária, "higienização” e degradação dos espaços públicos, sente carinho pelo lugar, porque este é feito de pessoas. São as pessoas da cidade, com seus problemas específicos de abastecimento, segurança alimentar, carestia, que movem Ana Terra em sua luta por um mundo sustentável.

Para a pequena Luana, São Paulo, vista do alto dos seus doze anos é o caos. Violência injustificada e injustificável, medo, auto-encarceramento, deturpações morais e éticas, briga, morte e arbitrariedade dos que detêm o poder a tornam uma criança assustada, que pouco passeia, que não vive a “experiência da rua”, não brinca naquele espaço temendo que algum mal aconteça consigo ou com os colegas. Fechada no pequeno apartamento onde mora com a mãe, no Jardim Ângela, Luana sonha com o tempo em que vivia no Nordeste, no sítio de seu avô e podia brincar livremente, correr, colher as frutas que sentisse vontade de comer, ir a escola e fazer as travessuras próprias da infância.

Apesar de jovem, Luana já sente a fragmentação causada pela cidade. Sente-se dividida entre viver na periferia de uma grande cidade, tendo seu pai por perto, e o desejo de voltar para o Piauí, onde acredita que seria mais feliz. Como síntese desses dois mundos Luana possui a chácara do pai - um pequeno éden no meio do caos da metrópole - lá ela encontra as coisas que tinha no Nordeste: a fartura, os pássaros, o silêncio, as relações amigáveis, mas como todo paraíso, este também costuma ter suas portas fechadas e seus moradores condenados ao trabalho e à dor. O lugar existe, mas ela passa meses sem poder ir lá, porque seu pai, um exímio pedreiro, tem que trabalhar até mesmo nos sábados e domingos, não tendo tempo de desfrutar de sua chácara nem do carinho de sua filha.

Para Filipe, o irmão mais velho de Luana, que acabou tendo que assumir o papel de “homem da casa”, São Paulo é uma cidade inacessível na qual as responsabilidades do trabalho consomem seu tempo. Apesar disso, é uma pessoa atenta ao que está acontecendo, crítica da política local e que possui também outros referenciais urbanos, dedicando-se, quando lhe é possível, a desbravar as cidades por onde passa.

Todas essas pessoas cultivam um ideal de cidade e se juntássemos cada um deles teríamos uma cidade com a seguinte configuração: com casas simples e aconchegantes, equipamentos urbanos como escolas, quadras de esporte, postos de saúde, ilhas digitais, parques bem cuidados e abertos ao povo, com áreas verdes e espaço para apresentações artísticas, com pessoas bem alimentadas e dispostas a trabalhar não apenas para si, mas para o bem-estar da comunidade. Na cidade ideal existe o que falta na real, mas estas pessoas, além de imaginar, de 
sonhar e fazer planos para o futuro, fazem também política. Muitas delas se envolveram com Movimentos Sociais que lutam por reforma urbana e moradia. 


\section{REFLEXÕES SOBRE O EIXO DA PESQUISA}

Esse estudo tem por tema memória, família e cidade. Foram modulados pelo conjunto das histórias de vida que compõem o presente texto. A partir de sua leitura, entendemos que esse deveria ser o principal eixo de nossa discussão.

A reflexão sobre a Memória encontra sua razão de ser no fato de que é por intermédio dela que os colaboradores desta pesquisa tecem suas histórias. $\mathrm{O}$ ato de narrar é essencialmente recordar e recriar experiências, atribuindo-lhes valores à luz do Presente, das crenças, ideologias e necessidades que ele comporta.

Memória é concebida como conjunto de impressões, imagens, lembranças e experiências que se reatualizam através da linguagem ${ }^{61}$. Tem como suporte a "vida vivida” e a vida sonhada e tanto em suas versões individuais, quanto coletiva, é algo em constante construção, inacabado, sujeito a reformulações. Essas versões da memória encontram-se freqüentemente em disputa, o que conduz a novas reescritas da História e do Poder.

Por uma perspectiva encontram-se as instâncias reguladoras, preservadoras e construtoras da Memória Oficial, e por outra, discursos variados e divergentes que se expressam inclusive pelo silêncio. Constata-se a existência de experiências singulares marcantes, bem como maneiras peculiares de vivenciar os fatos que se contrapõem aos discursos dominantes sobre o passado e exigem nova negociação. Essa memória "subterrânea”, ocultada pela dominante, "quando emerge e invade o espaço público traz à tona reivindicações múltiplas e imprevisíveis a essa disputa da memória” ${ }^{62}$. As entrevistas realizadas com famílias de Itapecerica da Serra (SP) e de Porto Velho (RO) são ilustrativas de tal afirmação. Mais do que um lugar para morar, reivindicam reforma urbana e um lugar na historiografia:

Estou no MTST desde a época da ocupação Chico Mendes, que desencadeou uma luta muito grande por reforma urbana nessa região de Taboão da Serra, Itapecerica da Serra. (Marcos)

Acho importante esse tipo de trabalho baseado na história de vida de pessoas como eu, porque até hoje o que está na história, nos livros e é ensinado para os estudantes no colégio é que o Brasil foi construído por homens brancos de origem européia. Cadê as mulheres nessa história? Cadê os negros? Por que os índios não aparecem? Não somos a minoria - como eles falam e querem fazer a gente acreditar - e esse país foi feito com o nosso trabalho, com os nossos esforços e isso precisa ser conhecido e valorizado! A gente tem uma experiência de vida para

\footnotetext{
${ }^{61}$ KOTRE, John. LUVAS BRANCAS: COMO CRIAMOS A NÓS MESMOS ATRAVÉS DA MEMÓRIA. São Paulo: Mandarim, 1997.

${ }^{62}$ POLLAK, Michael. MEMÓRIA, ESQUECIMENTO, SILÊNCIO. Estudos Históricos, Rio de Janeiro, vol. 2, n.3, 1989, p.3-15.
} 
contar, uma experiência de sobrevivência e trabalho. No meu caso não foi uma experiência muito boa. (Maria da Paixão).

O trecho acima destacado da narrativa do Marcos remete a um projeto político complexo, que vai além do imediatismo das necessidades - como ter uma casa, por exemplo - e disputa poder em espaços públicos, mediante atos e passeatas. Remete-nos também à questão do pertencimento e da identidade. O excerto do texto de Maria da Paixão questiona um modelo de historiografia que retrata uma ideologia elitista de graves conseqüências para a classe trabalhadora em geral, e para os indivíduos que compõem as denominadas "minorias étnicas” ou de "gênero inferior", e nos coloca diante também da polêmica existente entre História e Memória. Polêmica que, diga-se de passagem, passou a vigorar a partir do Iluminismo, com seus ideais de ciência e verdade, já que na Antiguidade a História e a Memória andavam juntas e a segunda, expressa em testemunhos orais era o cerne da primeira.

A História, a partir de meados do século XX tem ampliado seus objetos e metodologias de pesquisa e aceitado a "heterologia como missão". No lugar de uma história tradicional, imbuída da idéia de progresso e que rejeita tudo o que se opõe ou escapa à lógica linear, acomoda-se uma história "volúvel e caprichosa", mutante, inquieta perante aquilo que a história dos fatos consumados, do fim definido, da rígida razão formal ou dialética, excluía: a presença de outros atores, de outras histórias e narrativas, a necessidade de buscar outras partes, não para explicá-las à luz do já sabido ou antevisto, mas para compreendê-las e interpretá-las em sua experiência e historicidade ${ }^{63}$

No encalço desse novo posicionamento uma dada concepção de história oral ${ }^{64}$ tem colaborado com essa História que pouco a pouco se mostra "fruto de múltiplos temas e focos narrativos”, 65 , e para além disso, tem se constituído em um "Sistema”, onde não é mais somente a parte procedimental, mas toda a articulação que compreende desde a elaboração do projeto até a construção de uma interpretação própria ${ }^{66}$. Esta história oral aponta para pelo menos dois caminhos: um que se volta para a formulação de políticas públicas como imperativo ético da relação com os colaboradores, e outro, atento a questões relativas ao texto e à narratividade, construindo sua dimensão política em outra esfera, na da consciência do Eu que se expressa na narração de sua experiência de vida, e por meio dela consegue dar sentido à sua existência ${ }^{67}$. Ambos os caminhos não excluem a preocupação com as questões da memória, da identidade, da

\footnotetext{
${ }^{63}$ PINTO, Júlio Pimentel. A LEITURA E SEUS LUGARES. São Paulo: Estação Liberdade, 2004.

${ }^{64}$ Refiro-me a história oral desenvolvida pelo professor José Carlos Sebe Bom Meihy, junto ao Núcleo de Estudos em História Oral.

${ }^{65}$ PINTO, op. cit.

${ }^{66}$ BARBOSA, op. cit.

${ }^{67}$ BARBOSA, op.cit.
} 
subjetividade e tem constituído um núcleo conceitual e procedimental específico acerca desses elementos, que se diferencia do elaborado pelas Ciências Sociais, pela Psicologia e Psicanálise.

A relação entre memória, identidade e comunidade se destacam nas narrativas, por isso decidimos examiná-la mais de perto:

\section{Memória, Identidade, Comunidade}

Iniciamos nossa análise pela Memória, visto que o ato de narrar é constituído pelo trabalho de recordar, recriar e reavaliar as experiências passadas. Entendemos essa memória como fenômeno construído coletivamente e em constante transformação, portanto, coletiva, social. Sob esse prisma, ala ganhou destaque na obra “A Memória Coeltiva”, do sociólogo Maurice Halbwachs ${ }^{68}$, na qual se dedicou a discutir a memória individual e a coletiva, a memória coletiva e a histórica e a memória coletiva em sua relação com o tempo e o espaço. Esse último aspecto mostrou-se de vital importância para esta pesquisa, como veremos adiante.

Halbwachs enfatiza a memória coletiva porque por mais que a memória pareça expressar experiências individuais, é constituída por estruturas sociais que antecedem ao indivíduo, até porque não existe o “ser” sozinho. Afirma: “Nossas lembranças permanecem coletivas e nos são lembradas por outros, inda que se trate de eventos em que somente nós estivemos envolvidos e objetos que somente nós vimos. Isto acontece porque jamais estamos sós”69

A memória coletiva forma-se a partir de uma “comunidade afetiva” e caracteriza-se por ser fluida e plural, por estar em constante negociação com a memória individual. O conceito de comunidade afetiva, cunhado por Pollak ${ }^{70}$ refere-se a um grupo que tem em comum um trauma. O caso que ele apresenta é o dos judeus em campo de concentração, que passaram por situações limite de violência e trauma, expressos nas perdas que sofreram: convívio social, família, bens materiais, esperanças, perda da capacidade de narrar o horror, de conversar sobre a experiência vivenciada, o que fez com que muitos sobreviventes do Holocausto mergulhassem em uma vida de silêncio, conforme apontado na obra acima referida. Experiências desse tipo, ou similares a elas quando não expressadas podem constituir uma memória "subterrânea”, ocultada pela dominante, mas quando emerge e invade o espaço público traz à tona reivindicações múltiplas e imprevisíveis a essa disputa da memória.

Ressalvadas as devidas proporções e o contexto histórico, as famílias que se uniram em torno do MTST e do Movimento dos Trabalhadores Sem-Teto de Rondônia, também oriundas de experiências traumáticas específicas, trazem consigo as lembranças dessa vida anterior ao

\footnotetext{
${ }^{68}$ HALBWACHS, Maurice. A MEMÓRIA COLETIVA. São Paulo: Ed. Centauro, 2006.

${ }^{69}$ HALBWACHS, op. cit., p.30.

${ }^{70}$ POLLAK, op. cit. p. 6.
} 
ingresso nesses Movimentos Sociais, constituem uma comunidade afetiva e tentam, por meio dela reconstruírem sua vida e dignidade. O que é coletivo, neste caso, é a falta: de moradia, de emprego, educação, saúde, saneamento básico, transporte de qualidade. Claro que esses problemas não atingem apenas a eles, são vivenciados pela maior parte da sociedade brasileira, contudo, os trabalhadores aos quais nos referimos encontram-se unidos ideológica e geograficamente por essa experiência de “não possuir” e a partir dela buscam alternativas para superar essa situação, que é acima de tudo, de humilhação, de rebaixamento. De acordo com Suzana Lopes Salgado Ribeiro, estudiosa do MST, e fazendo um paralelo entre esses dois Movimentos Sociais (MST/MTST), “(...) pode-se dizer que suas memórias conformam-se a partir de perdas significativas a que foram historicamente submetidos”71.

A experiência de "não possuir" um teto, um trabalho ou não poder contar com serviços sociais de primeira necessidade, como escolas e hospitais, mobilizam as famílias em torno de um projeto, que apresenta dois objetivos: a) a sobrevivência do grupo perante as adversidades peculiares a um país de capitalismo periférico, marcado por uma industrialização tardia, migrações em massa, desemprego estrutural e histórica disparidades na distribuição de renda; b) a transformação social, que alguns integrantes das famílias entendem como algo que deve ser promovido de “cima para baixo”, ou seja, a partir da iniciativa dos políticos, e que outros entendem como algo que deve ser feito por “nós”. Esse projeto está em constante negociação, ora é aceito, ora é refutado pelos membros da família e nele, diversas "metodologias” são testadas: "trabalhar e militar”, "militar e não trabalhar fora da ocupação”, "apenas trabalhar”, “esperar por Deus e pelo Governo”, “ir à luta e não esperar por ninguém”.

Esse projeto, em seu aspecto familiar preocupa-se com “a melhoria de vida”, e em seu aspecto mais amplo preocupa-se com a questão da "cidadania para todos", da efetivação dos direitos, como pode ser notado nos textos a seguir. Laura, ao ingressar no MTST possui como meta conseguir uma casa não apenas para si, mas para a mãe e os irmãos, a fim de melhorar a condição de vida da família:

[...] um dia entramos na ocupação do Valo Velho, com o sonho de conseguirmos nossa casa, não só para gente, mas para nossas mães também, porque elas pagam aluguel.

Maria da Paixão expressa sua perplexidade com relação à política habitacional e o caráter de necessidade humana de um lugar par morar:

\footnotetext{
${ }^{71}$ RIBEIRO, Suzana Lopes Salgado. TRAMAS E TRAUMAS: IDENTIDADES EM MARCHA. São Paulo, FFLCH/USP, 2007. (Tese de Doutorado).
} 
Meu Deus, para gente ter uma moradia não precisava tanta coisa! Somos seres humanos, cada ser humano merece ter um teto para morar O que acho errado no nosso governador, é eles permitirem que tenha pessoas vivendo assim no nosso país e eles ainda são capazes de nos negar um lugar para viver. Ninguém aqui está querendo luxo, mansão, estão querendo um cantinho para morar porque não têm condições de pagar um aluguel, aluguel está difícil! Eu pago R\$: 220,00 de aluguel e só falto morrer, tem horas que falta o leite da Caroline, falta a fralda, falta o pão de cada dia dentro de casa, mas tenho que pagar o aluguel! O que estamos atrás é de uma moradia, não é de luxo, de mansão, de apartamento chique. Queremos simplesmente um lugar para viver. É necessário, todo ser humano precisa de uma moradia.

Carla também aponta para o caráter político do problema habitacional e de como a negação de direitos influi negativamente na sociedade:

Muitos direitos e necessidades não são respeitados, como o direito/necessidade de ter um lar, uma casa, um emprego e isso acaba refletindo negativamente na sociedade. Por falta de um lar para morar, por falta de um emprego, o índice de marginalização tem crescido cada vez mais, e como conseqüência disso, a violência.

Parece haver, todavia, no que tange ao desenvolvimento desse projeto familiar, uma dificuldade em conciliar as duas esferas: a pública e a privada, o que levou Tonho a se pronunciar nesses termos:

Hoje, particularmente, se eu falar para você que não luto por uma melhor condição financeira estarei mentindo. Hoje luto mais pela questão financeira, por causa da minha esposa, mas se não fosse isso, seria apenas luta pelo povo, luta por justiça social... Ainda sou comprometido com essas causas, sempre serei, mas agora a prioridade é o bem-estar da Laura, que conheci também na luta e que tem os mesmos princípios e ideais que eu.

Ana Terra pronuncia-se sobre o aspecto coletivo, político e seu projeto de vida nestes termos:

Não é abrir mão da vida ou de certo tipo de vida, é querer ter um outro. Não é abrir mão de ter dinheiro ou fazer uma carreira "bem sucedida", é querer ter outras coisas que não dinheiro e que o dinheiro impede a gente de ter... E ter outras coisas que não uma "carreira bem sucedida”, porque esse “bem sucedida” é um falseamento, uma interpretação.

Os dois aspectos (privado e coletivo) estão presentes nos projetos das famílias colaboradoras desta pesquisa. É evidente a busca por uma existência material mais confortável: o 
desejo de Maria da Paixão retornar para sua casa e sua terra, o desejo de Caio de conseguir uma casa para abrigar a família que acaba de formar, a preocupação de Camila em conseguir um lugar que seja seu; assim como é evidente a leitura política que colaboradores como Carla, Marcos e Filipe fazem do fenômeno do "desrespeito aos direitos” e decidem, ou não, se engajar na luta pela sua efetivação.

Se o principal elemento da memória coletiva dos grupos estudados é a falta, sentida e vivenciada de modo específico pelos indivíduos, mas em uma comunidade que produz discursos e ações singulares a esse respeito, a identidade também é elaborada sobre esse suporte.

A vida pelo “não” identifica e diferencia essas pessoas, mas a construção dessas identidades não é algo simples e realizado sem conflito e argumentação, pois naquelas comunidades afetivas (ocupações João Cândido e Chico Mendes) chegam pessoas a toda hora, pessoas que não se conhecem e que trazem consigo experiências diversificadas do "não ter”. Há as que migraram de outras ocupações de sem-teto, que possuem conhecimentos da vida em Movimento Social ${ }^{72}$, há as que sempre viveram nas ruas, as que possuíam casa e a perderam, as que possuem casa, os jovens que moravam com os pais e saíram de casa em busca de liberdade, os que acreditam estar apenas "temporiamente"73 na condição de sem teto, os intelectuais orgânicos, os que foram para lá porque não havia outra alternativa, e os que foram por uma escolha de militância.

Muitos chegam às ocupações praticamente sem identidade, pois a dignidade ferida não os permite sequer reconhecerem-se como inteiramente homem ou inteiramente mulher e nem mesmo como brasileiros, nordestinos ou sulistas. Levam para as ocupações os fragmentos de sua luta. Não possuem mais o emprego ou a vida escolar, que lhes dava a identidade de "profissional do ramo de...”, de "trabalhador” ou "estudante”. Falta a casa que lhes conferia a identidade de “dona de casa” e com isso, muitas vezes a própria família se desintegra, o que afeta também a identidade de "pai de família e mãe de família”. Diante dessa perda é preciso construir novas identidades, a começar pela de “sem-teto” e tal tarefa não é fácil, pois se refere não apenas ao que somos, mas a como os outros nos reconhecem, a como nos vêem. Sabe-se que muitas vezes essa visão é preconceituosa e estereotipada e que as ações se moldam sob a visão, o que aumenta o desconforto daquele que está em foco.

Diante da situação apresentada as pessoas que nela se vêem inserida entendem como necessária a construção de nova identidade, porém vivem momentos de angústia e incerteza

\footnotetext{
72 Sabem, por exemplo, que a vida nesses Movimentos deve ser vivida prioritariamente “no coletivo” e não no “individual”, no plural e não no singular. Lembro de uma colaboradora que perguntou a um militante antigo: "Como eu vou fazer para sobreviver aqui se não tenho emprego? Ele disse: "Sua pergunta está errada, aqui não tem o "eu”, tem o "nós". Coletivamente é que garantimos o nosso sustento".

${ }^{73}$ Esse "temporariamente" está relacionado a um tempo muito curto, de dias ou meses. Diz respeito a pessoas que tem um projeto de em poucos dias ou meses voltar para a terra natal ou conseguir um emprego que permita alugar um apartamento. Coisa que nem sempre acontece.
} 
quanto a se é esta a via correta a ser percorrida. Se é a "identidade de sem-teto" que deve ser construída. De acordo com Halbwachs,

\begin{abstract}
"Quando algum acontecimento [...] obriga a que nos transportemos a um novo ambiente material, antes que a ele nos tenhamos adaptado, atravessamos um período de incerteza, como se houvéssemos deixado para trás toda a nossa personalidade: tanto isso é verdade, que as imagens habituais do mundo exterior são partes inseparáveis de nosso eu"74
\end{abstract}

Percebemos então que a identidade possui vínculos profundos com o espaço porque, é sobre ele que as comunidades se constroem e dialeticamente, constroem o espaço, moldando-o à suas necessidade e sensos estéticos. Richard Morse, em entrevista concedida a José Carlos Sebe Bom Meihy ${ }^{75}$ ao recordar seus estudos sobre moradia e o sacrifício pelo qual os pobres passavam quando eram obrigados a abandonar seus cortiços, ressalta que estes não poderiam saber facilmente substituir o sentido de comunidade que haviam desenvolvido, o que se explica pelo fato de que é no espaço que a vida é estabelecida. Nele imprimimos nossas marcas e cada um dos objetos que ele abriga nos lembram as pessoas de nossa convivência, portanto, "quando os membros do grupo estão dispersos e nada encontram em seu novo ambiente material que recorde a casa e os quartos que deixaram, mas permanecem unidos pelo espaço é porque pensam nessa casa e nesses quartos"76.

A identidade dos integrantes do MTST e do Movimento dos trabalhadores sem-teto de Rondônia é elaborada, dessa forma, em espaços definidos: acampamentos localizados em terrenos urbanos que não cumprem sua função social, em uma comunidade unida por experiências dolorosas que os levou a situação de degradação social e que se mantém unida pelo que sobrou da casa, ou seja, sua recordação. Essa casa perdida pode ser a casa própria, a casa paterna, a casa da infância ou mesmo a casa que nunca existiu, mas que a pessoa deseja ter.

O processo de criação de identidade está em constante movimento, não é algo consolidado, definitivo e único. Com relação aos desafios próprios desse processo, gostaríamos de destacar que o "ser sem-teto" só costuma ser bem-aceito se vier acompanhado da identidade de "trabalhador": trabalhador sem-teto, trabalhadora sem-teto. Isso porque o trabalho é um valor bastante prezado nas sociedades capitalistas. Por meio dele o trabalhador espera receber uma “recompensa” pecuniária suficiente para o sustento de sua vida e da vida de sua família. Por seu intermédio os donos dos meios de produção almejam aumentar suas tachas de lucro, tomando

\footnotetext{
${ }^{74}$ HALBWACHS, Maurice. A MEMÓRIA COLETIVA. São Paulo: Ed. Centauro, 2006, p.157.

${ }^{75}$ MEIHY, José Carlos Sebe Bom. A COLÔNIA BRASILIANISTA. São Paulo: Nova Stella Editorial, 1990, p.139161.

${ }^{76}$ HALBWACHS, op. cit., p,159.
} 
para si a diferença entre o valor produzido pelo trabalho e o salário pago ao trabalhador (MaisValia $)^{77}$.

Essas identidades são forjadas em comunidade: coletivamente e em um espaço de uso em comum. No que se refere a esse último, destacamos que é onlugar onde as famílias em busca de moradia indicam em suas narrativas, que sentem acolhidas, que se sentem também “em família”. É onde encontram maior segurança e de onde retiram força para continuar a vida e mais que isso, para lutar por uma vida melhor. Nas palavras de Bauman, a comunidade é:

\footnotetext{
“(...) o lugar “cálido”, um lugar confortável e aconchegante. É como um teto sobre o qual nos abrigamos da chuva pesada, como uma lareira diante da qual esquentamos a mão diante de um dia gelado. Lá fora, na rua, toda sorte de perigo a espreita; temos que estar alertas quando saímos (...) Na comunidade podemos relaxar - estamos seguros, não há perigos ocultos em cantos escuros”. 78
}

O pertencimento à comunidade João Cândido e Chico Mendes é expresso em palavras: “nós”, “a gente”, e remete a um vocabulário e a uma memória coletiva que ressaltam um modo de ser, de pensar e de lembrar de uma coletividade ${ }^{79}$, o que pode ser encontrado, por exemplo, nos nomes das ocupações e brigadas, que semelhante às do MST, homenageiam e encontram inspiração em personagens históricos como João Cândido, Chico Mendes, Zumbi dos Palmares, Dandara e Anita Garibaldi. Contudo, entendemos que o pertencimento e a identidade não têm a solidez de uma rocha, não são garantidos para toda a vida, mostrando-se negociáveis e revogáveis, e de que as decisões que o próprio indivíduo toma, os caminhos que percorre, a maneira como age - e a determinação de se manter firme a tudo isso - são fatores cruciais tanto para o "pertencimento" quanto para a identidade". ${ }^{80}$ A complexidade dessa construção identitária e a vinculação àquelas comunidades torna-se ainda mais complexa se pensarmos que a identidade de sem-teto é elaborada desde o início com a intenção de ser provisória. Nossos colaboradores que se identificam como sem-teto, e mesmo os que não apresentam essa identidade mas também estão em busca de uma casa, desejam a identidade de “morador”, de cidadão integrado na cidade. A identidade de sem-teto é vista como um caminho para mobilizar a opinião pública, o Terceiro Setor e o Estado para um debate sobre a crise urbana, que possui na questão da moradia uma de suas pautas mais urgentes. O que acontece quando essa demanda é satisfeita, quando as pessoas deixam a identidade de sem-teto para assumir a de morador e de cidadão integrado?

\footnotetext{
${ }^{77}$ O conceito de Mais-valia foi explorado por Karl Marx na obra O Capital, livro 1, v. 1, especialmente na terceira e quarta parte.

${ }^{78}$ BAUMAN, Zigmunt. COMUNIDADE. Rio de Janeiro: Jorge Zahar Editor, 2003, p.7-8.

${ }^{79}$ Ribeiro, ibidem, p. 194.

${ }^{80}$ BAUMAN, Zigmunt. IDENTIDADE. Rio de Janeiro: Jorge Zahar editor, 2005, p.17-18.
} 
Primeiramente cabe enfatizar que essa demanda nunca é completamente satisfeita, pois se trata de um problema estrutural que não pode ser solucionado sem alterar posições historicamente definidas de poder - o que só seria feito de modo integral com a substituição do bloco hegemônico vigente. Em segundo lugar, devemos pensar o problema por pelo menos dois ângulos: o que significa a posse de uma casa para aqueles que lutaram para isso; e o que significa a posse de uma casa para os Movimentos Sociais que a tem como pauta de seus projetos. Qual o sentido de ter uma casa para os primeiros? Quais as conseqüências disso para o segundo?

\section{Os sentidos do ter e os Movimentos Sociais}

Chegamos ao ponto da discussão sobre os significados da propriedade privada, das contingências populares e agência de Movimentos Sociais como MTST e o Movimento do Trabalhadores Sem-Teto de Rondônia.

A maior parte das famílias que se inseriram na luta por reforma urbana junto a esses Movimentos Sociais apresenta necessidades prementes, dentre elas a de residir em moradia adequada. Dado a urgência dessa necessidade e as dificuldades financeiras para supri-la por conta própria, uma alternativa é o diálogo com o Poder Municipal e o Estado, a fim de pressionar a criação de políticas públicas para esse fim, de legalização das áreas ocupadas e instalação de infra-estrutura. Ao ter essa demanda satisfeita (ou parcialmente satisfeita), o que resta da antiga identidade e o que significa a nova, de “morador”, de “proprietário”? Como dissemos, procuraremos ver esse problema por dois ângulos: o dos que “conseguem esse bem”, que lutaram por ele, e o dos Movimentos Sociais que os representam ou representavam.

No que reporta ao prisma dos que lutaram para conquistar uma casa para morar (e não para vender), essa significa a possibilidade de uma vida estável, fixa, e não mais transitória, insegura e incerta. Significa também a possibilidade de ser tratado com respeito, de ser chamado de "senhor", de "senhora”, de ser visto como alguém integrado à sociedade, e não alguém que “força” essa integração, “invadindo o que é dos outros”. Entendo que assim como para as famílias de meninos de rua com as quais Ataíde trabalhou, o "ter uma moradia”, para os nossos colaboradores significa ocupar socialmente um espaço, exercendo direitos de cidadania. Significa ter um endereço e, a partir desse referencial, apresentar-se como cidadão, consumidor, chefe de família e habilitar-se a pleitear a admissão a um emprego, escola para os filhos, auxíliodesemprego ou auxílio humanitário de alguma instituição ou igreja ${ }^{81}$. A conquista da casa corresponderia ao marco inicial de uma nova vida.

\footnotetext{
${ }^{81}$ ATAÍDE, op.cit., p. 224.
} 
A casa tem o sentido de abrigo, traz a idéia de aconchego e intimidade, de "lugar da família”, que se opõe ao espaço da rua ${ }^{82}$. Mas não podemos nos esquecer de sua outra conotação, a de propriedade e o que significa. Em uma sociedade capitalista como a nossa - em que a lógica do ter se sobrepõe a todas as outras - o não ter uma "propriedade”, um emprego ou ser despossuído de determinados bens materiais, como uma casa ou mesmo um aparelho celular “moderno” são motivos de exclusão, ou na “melhor” das hipóteses: de preconceito e tratamento desrespeitoso. O que pode ser fatal em situações de emergência, como as de doença em que se depende dos serviços públicos de saúde. Um exemplo trágico disso foi narrado por Laura em uma de nossas conversas, quando ela chegou ao posto de saúde passando mal, e por não ter comprovante de residência, por ser sem-teto, demorou a ser atendida e acabou perdendo seu bebê na sala de espera. Laura estava grávida de três meses e fazia o enxoval da criança com alegria, apesar da insegurança de ser “mãe de primeira viagem”.

Tendo como campo de interesse a relação dos Movimentos Sociais com a questão da propriedade e com seus integrantes Rodrigues e Brito assinalam que:

Ao assumiram a necessidade de 'ser igual' dentro do espaço urbano, os assentados na verdade continuam ajudando a compor as diferenças sociais contra as quais o MTST se coloca contra. Ser igual acaba se reduzindo a ter também água, luz e esgoto. As diferenças silenciadas nessa igualdade tendem a aumentar. Ao formularem o desejo de sair da condição de 'invasor' para a de 'cidadão', o sentido de 'morador', daquele que pode vir a ter voz, fica diluído. Os assentados distanciam-se da adesão política que o fazer parte do MTST exige e aproximan-no da possibilidade de ser reduzido a um veículo de alcance da 'esfera privada. ${ }^{83}$

Tornar-se apenas um “veículo de alcance da esfera privada” é uma possibilidade gerada pelo diálogo desses Movimentos Sociais com o Estado. Diálogo que em suma, não consegue estabelecer um consenso sobre o que é cidadania, visto que as ações direcionadas a ela revelam inúmeros equívocos. O primeiro deles diz respeito às intervenções do Estado no espaço das ocupações (instalação de energia elétrica, água, coleta de lixo) e a reivindicação desses serviços pelos Movimentos Sociais, como sendo “cidadania”. É fato que a intervenção estatal nesses territórios “desviantes” do ponto de vista do planejamento urbano

[...] é fundamental para que seus moradores tenham condições de vida aceitas como mínimas em nossa organização social. No entanto, reivindicar essa intervenção como um exercício de cidadania é justamente ficar no equívoco, produzindo um achatamento do político com uma

\footnotetext{
${ }^{82}$ DAMATTA, Roberto. A CASA E A RUA. Guanabara: Rocco, 1991.

83 RODRIGUES, Suzy Lagazzi; BRITO, Priscila Salvato. AS OCUPAÇÕES DOS SEM-TETO NA DISCURSIVIDADE DA CIDADE. In: ORLANDI, Eni P. CIDADE ATRAVESSADA: OS SENTIDOS PÚBLICOS NO ESPAÇO URBANO. Campinas: Ed. Pontes, 2001, p.57.
} 
concepção domesticada de cidadania. Sem dúvida, cidadania é também ter boas condições de vida e, fundamentalmente, conseguir reconhecer na ordem da cidade possibilidades de mudança. Em nosso imaginário social, cidadania e infra-estrutura têm muitas coisas se equiparando e esse é um dos equívocos que sustentam a ordem urbana. A reivindicação de infra-estrutura como cidadania tem levado ao apagamento do político e da contradição como possibilidade de desestabilizar a organização social.

A questão tem seu grau de complexidade ampliado quando pensamos que as intervenções no território das ocupações, a construção de algumas dezenas ou centenas de casas populares, bem como o cadastro para conseguir um apartamento da CDHU pode ser apenas uma forma de cooptação dos Movimentos Sociais pelo Estado, de neutralização de suas forças. No caso do Movimento dos Trabalhadores Sem-Teto de Rondônia, organizador da ocupação Chico Mendes, em Porto Velho, que se metamorfoseou em uma associação de moradores “Amigos de Roberto Sobrinho”, o atual prefeito da cidade, é visível a neutralização desse Movimento pelo poder administrativo local, ou o que é ainda mais sério, da corrupção dos princípios desse Movimento por um pragmatismo duvidoso. Ao perguntar a um integrante daquela ocupação o porquê do Movimento ter se transformado em uma associação de "moradores amigos" do prefeito, ele me disse que aquele era o caminho mais prático para se conseguir a legalização do terreno e a verba para o mutirão construir as casas. Não podemos negligenciar também um fator importante nesse processo de "cooptação" daquele Movimento pela Prefeitura ou de seu "deslocamento voluntário” para aquele lado: o fator carisma. Roberto Sobrinho, com seu discurso petista, bem articulado e sua aparência sóbria de professor, ganhou logo no primeiro turno as duas eleições que disputou para prefeito em Porto Velho, com ampla vantagem de votos.

Diante do exposto, podemos nos perguntar: qual é o espaço dado ao político na cidade? As ocupações parecem consumir boa parte de seu tempo em sua própria organização e reivindicação de suprimento de suas necessidades básicas, muitas vezes realizando uma metonímia do “conceito” de cidadania por seu “objeto”, ou melhor, por seus objetos: casa, escola, telefone público, luz elétrica, água tratada - o que não quer dizer que esses “objetos” não devam ser reivindicados. O poder público, por sua vez, apresenta uma "tendência” a legalizar as ocupações e enquadrá-las ao cenário urbano, tentando demonstrar, com isso, que tem controle sobre o caos que impera na cidade. Que espaços restam para o debate sobre a cidade e suas dicotomias?

Reconhecemos de todo modo, a importância dos Movimentos Sociais, que nos interstícios da cidade e dos sistemas produtivos edificam sua crítica à ordem vigente e tornam mais explícitas suas contradições. 


\section{Movimentos Sociais e a Luta na Cidade}

Apesar de todas as transformações políticas, técnicas e científicas pelas quais o Brasil tem passado, não conseguiu superar problemas básicos como a concentração fundiária e de renda e a ineficácia de suas políticas de habitação. Diante disso, inúmeras mobilizações reivindicatórias, têm se organizado com a meta de transformar esse cenário, cada qual com configuração específica: organização, estratégias de ação e demandas condizentes com a realidade do momento histórico no qual estão situadas.

Os Movimentos Sociais são produtos de sua época, nascem da organização de cidadãos, consumidores, usuários de bens e serviços que atuam junto a bases sociais mobilizadas por problemas decorrentes de seus interesses e necessidades cotidianas ${ }^{84}$. Na lista desses problemas pode-se citar a falta de moradia, de atendimento médico, de educação e transporte de qualidade, de acesso à cidade e seus equipamentos, ao campo e às condições de nele permanecer. São decorrentes de um crescente processo de acirramento dos antagonismos e da exclusão social fundada sobre mecanismos inerentes ao modo de produção capitalista e ao sistema de gestão político-administrativa do país. Como o próprio nome sugere, Movimentos Sociais são, por definição, dinâmicos, marcados pela não-estabilidade e pela luta de classes, e estas classes, por sua vez, não estão "prontas e acabadas", mas vivenciam na luta diária seu constante processo de formação, daí a importância da noção de experiência somado a das condições materiais, objetivas que compõem esse processo. Caracterizam-se como práticas coletivas que contam com certa organização e projeto político, no qual está incluída sua pauta de reivindicações.

De acordo com Peruzzo,

[...]os movimentos populares vivenciam diferentes etapas e momentos. Há os que já atingiram graus elevados de organização, articulação, ação coletiva e consciência política, enquanto outros estão começando, se acham numa fase intermediária ou estão tentando se recuperar de recuos. Por isso é impossível ver neles uma homogeneidade ou mesmo ou um padrão único em sua experiência democrática, que alguns exercitam mais que os outros, apesar de todos se pautarem, de alguma forma, pela democracia direta. ${ }^{85}$

No Brasil, depois de 21 anos de ditadura militar (1964 - 1985), as classes populares que por todo aquele tempo estiveram banidas da democracia, espoliadas e limitadas em suas possibilidades de ser, voltaram a se organizar com liberdade em torno da reivindicação de seus

\footnotetext{
${ }^{84}$ GONH, Maria da Glória. TEORIA DOS MOVIMENTOS SOCIAIS: PARADIGMAS CLÁSSICOS E CONTEMPORÂNEOS. Ed. Loyola, São Paulo, 1997.

${ }^{85}$ PERUZZO, Cicília M $M^{\mathrm{a}}$ Krohling. COMUNICAÇÃO NOS MOVIMENTOS POPULARES. Petrópolis: Vozes, 1998.
} 
direitos $^{86}$. A abertura democrática, assim como o aparecimento de novos Movimentos Sociais foi vista por muitos de maneira otimista. Projetavam-se neles os germes de uma nova cultura política, um novo canal de acesso ao Estado, complementar e independente dos tradicionais partidos políticos e sindicatos, e de uma nova sociedade, capaz de superar as históricas desigualdades sociais dando nova configuração ao espaço. Mas o oposto também aconteceu: foram subestimados e criticados. Seus integrantes receberam alcunhas de "politicamente despreparados”, “incultos” e "utópicos” e seus projetos alcunha de "paroquiais”, ou seja, sem grande alcance, limitados a um espaço restrito. Suas reivindicações, utilizadas como ferramenta de mobilização popular foram consideradas seu principal inimigo, pois acreditavam que quando estas fossem atendidas o movimento perderia sua razão de ser e se dissolveria. De fato muitas vezes isso aconteceu, muitos Movimentos Sociais saíram de cena, mas é preciso salientar também, que muitos assumiram novas feições, atualizaram suas pautas e seguiram na luta, alguns, inclusive, alcançando abrangência nacional e internacional, como o Movimento dos Trabalhadores Sem Terra (MST), e outros se institucionalizando (como o movimento grevista do ABC paulista), que culminou na criação do Partido dos Trabalhadores (PT). ${ }^{87}$

Não podemos, dessa forma, superestimá-los ou subestimá-los. Precisamos compreendêlos dentro de sua própria lógica e campo de atuação, “entender seus fluxos e refluxos, sua capacidade de invenção e articulação com outras forças sociais, em face de acontecimentos que se desenrolam no caminhar da luta, cujos resultados não estão, de antemão, estipulados por categorias analíticas que estruturam os diversos agentes numa trama histórica previamente estabelecida" $^{88}$

Se no período da ditadura as lutas sociais se dirigiam contra o Estado e este era visto como o “inimigo número um”, hoje é encarado por muitos Movimentos, como parceiro. São muitas as organizações que visando maior eficácia na resolução de suas demandas tem firmado parceria com órgãos públicos das diversas esferas (federal, estadual e municipal), além de empresas e outras instituições. Cabe destacar ainda uma nova expressão de Movimento Social, as ONGs, que ganharam destaque a partir da década de 1990 e posicionam-se como mediadoras entre a sociedade e os detentores do poder político e econômico. As ONGs trazem para a ordem do dia a discussão de problemas concretos, que se manifestam tanto de forma material (como bens negados), como de forma como ética e moral (transparência política, fim da corrupção e preocupações ambientalistas, dentre outras).

\footnotetext{
${ }^{86}$ Não necessariamente direitos no sentido "institucionalizado", de norma jurídica, mas no sentido de uma percepção coletiva segundo a qual existe legitimidade na reivindicação por um benefício e que sua negação constitui crime, injustiça social.

${ }^{87}$ PERUZZO, op.cit.

${ }^{88}$ PERUZZO apud KOWARICK, op.cit., p. 34.
} 
Como áreas de atuação desses Movimentos, podemos identificar a cidade, o campo e até o ciberespaço, utilizado como meio de divulgação dos ideais pelos quais se luta, espaço de “guerrilha literária” e de sabotagem dos sistemas de segurança e informação do Governo e de grandes empresas.

No que diz respeito às lutas travadas na cidade - um dos nossos eixos de reflexão neste estudo - cabe salientar alguns aspectos específicos desse espaço, para melhor entender como e por que aquelas ocorrem.

Sabemos que não existe um modelo único de cidade. Existem cidades pequenas, médias, grandes, metrópoles. Cidades planejadas e "não-planejadas", que compõem regiões metropolitanas, que são “isoladas”, de difícil acesso, cidades marcadamente turísticas e “cidadesfantasma”, abandonadas por seus moradores por motivos econômicos ou de catástrofes da natureza. Apesar disso, muitas delas enfrentam problemas parecidos, como desemprego e subemprego, déficit de moradias, de saneamento básico, de equipamentos urbanos capazes de atender as necessidades da população e falta dos bens culturais que lhe são negados, como a participação em sua gestão, tornando-a de fato democrática.

Para compreender esses problemas e entender por que algumas pessoas tentam solucionálos por meio da participação em Movimentos Sociais, e outras permanecem indiferentes, apesar de também senti-los, ou lutam de outras formas, é preciso olhar a cidade por duas lentes diversas: analisá-la por referências “macroestruturais”, como a dinâmica de acumulação do capital, já que esta é uma das grandes responsáveis pelos atuais modelos de produção e apropriação do espaço; e pela "economia da experiência” dos indivíduos, ou seja, levando em conta o valor que atribuem às situações de exploração e humilhação que vivenciam no cotidiano. Pela vertente daquilo que estamos chamando de "economia da experiência” é possível compreender porque nem todos os membros de uma mesma família que possui integrantes vivendo em ocupações de trabalhadores sem-teto decide não participar, ou ao contrário, pessoas que não precisam diretamente de determinados recursos materiais, “decidem entrar na luta” para apoiar seus familiares. O texto de Filipe que veremos a seguir revela a dimensão de suas experiências, de suas interpretações do mundo e o que pensa sobre a militância de seus familiares junto ao MTST:

Cada um tem uma opinião, do meu ponto de vista a militância da minha irmã Laura e do meu cunhado Tonho é uma perda de tempo, mas sei que nem todo mundo pensa assim. Você fica correndo o tempo todo de um lado para o outro, vai em prefeitura daqui, prefeitura dali e ninguém está nem aí para você, ninguém está se preocupando com você estar lá acampado, sem recursos. Acho isso uma bagunça, se fosse uma coisa mais organizada, mais pé firme... Então para mim tanto faz, tanto fez. Não concordo com isso de você ter que morar em cabana, em barraco, essas coisas de lona, Deus me livre! Posso um dia chegar a precisar, estar em uma situação assim, mas acho que a saída é o trabalho. Ela pode muito bem arrumar um emprego e 
alugar uma casa. Já tem uns dois anos que a Laura está atrás disso e nunca saiu do mesmo lugar, não deu um passo à frente ainda, então acho que é perda de tempo. Sinceramente, não daria um dia do meu tempo para estar correndo atrás disso sem ter certeza que dali tiraria algo útil para mim e para todos.

Carla não conta em sua entrevista o motivo “pessoal” pelo qual ingressou no cotidiano da ocupação Chico Mendes, mas em uma de nossas conversas ela deixou claro que estava lá principalmente para apoiar os filhos que começavam a casar e não tinham condições de comprar ou construir suas casas. Em sua narrativa ela revela o caráter familiar e político de seu envolvimento com aquela ocupação:

Me envolvi em um outro projeto, que é simultaneamente familiar e político: a ocupação Chico Mendes. Comecei a participar daquela ocupação e contribuir da maneira que me era possível: motivando as pessoas, entrando em contato com advogados, elaborando cadastros. Fiz isso porque vi a necessidade daquelas pessoas de terem um lar, terem um teto.

A preocupação com a Família e as reminiscências da vida em família, das festas, dos trabalhos, das refeições e dificuldades enfrentadas são elementos-chave desta pesquisa, pois marcam as narrativas, tanto individual como conjuntamente. É na família que se desenvolvem a ampla parte das experiências narradas por nossos colaboradores e somado a isso, foi esse tipo de organização social que selecionamos como colônia ${ }^{89}$ desta pesquisa.

O conceito de família com o qual trabalhamos foi inferido da $5^{a}$ edição do Manual de História Oral, escrito pelo professor José Carlos Sebe Bom Meihy, em 2005. Optamos por trabalhar com esse conceito por melhor se adequar à realidade observada durante o trabalho de campo, dessa forma, a compreendemos como uma estrutura relacional composta por indivíduos que possuem entre si vínculos que geram comprometimento mútuo, solidariedade, identidade de projetos de vida e propósitos em comum ${ }^{90}$, embora esse comprometimento ou identificação nem sempre existam de forma total, sem restrições, divergências e conflitos.

A Família é uma instituição que tem passado por profundas mudanças ao longo dos séculos e pode ser vista como uma "arquitetura em movimento", ou seja, como uma construção social que acompanha o fluxo da sociedade. Para entendê-la em sua forma atual, faremos uma breve incursão na história.

Nosso referencial para a compreensão das transformações da família ocidental é a obra História Social da Criança e da Família ${ }^{91}$, que apresentou a sociedade medieval como densa e

\footnotetext{
${ }^{89}$ Explicamos esse conceito na parte A Escolha dos Procedimentos.

${ }^{90}$ MEIHY, op.cit., p.157.

${ }^{91}$ ARIÈS, Philipe. HISTÓRIA SOCIAL DA CRIANÇA E DA FAMÍLIA. Rio de Janeiro: Ed. Zahar, 1981.
} 
bastante sociável, inferindo, a partir disso, que a maior parte da vida dos homens e mulheres daquele período fosse passada em espaços públicos, e que era desse convívio constante, dessas relações sociais diariamente cultivadas que provinha a reputação e a fortuna das linhagens. Em contrapartida, tal "estilo" de vida teria retardado o surgimento do "sentimento de família”, tal qual possuímos hoje em dia, pois não havia a noção de intimidade e esta, assim como a de privacidade, foram construídas gradualmente. De acordo com Áries, “nessas existências densas e coletivas, não havia lugar para um setor privado. A família cumpria uma função - assegurava a transmissão da vida, dos bens e dos nomes - mas não penetrava muito longe na sensibilidade”92. O que havia de mais próximo de nosso moderno sentimento familiar talvez fosse o sentimento de pertença a uma linhagem, devido ao fato de ter existido um ancestral em comum aos outros “parentes”, mas na medida em que esse quadro foi se alterando, que o Estado passou a suprir a necessidade de segurança desse grupo de parentesco, esses laços foram se desfazendo e novas relações afetivas foram construídas, principalmente entre pais e filhos, limitando, no espaço da casa - que até então era mais público do que privado - a presença de amigos, conhecidos, clientes e empregados. O autor, na obra citada, destaca que o sentimento de família está ligado a casa e a seu governo, bem como à vida que nela se leva.

Bauman, na obra "Em Busca da Política” destaca que com o advento da Modernidade a família adquiriu nova relevância, que não encontra justificativa em simples preocupações econômicas. Em suas palavras:

\footnotetext{
Alguma outra coisa deve explicar a nova importância adquirida pela família e particularmente a difusão a todas as classes sociais modernas de constructos culturais de fidelidade conjugal, de amor paterno e materno e cuidados com as crianças (a própria infância vista como um período particularmente vulnerável que requer atenção). Essa outra coisa foi, com toda a probabilidade, o novo papel que coube à família face à evidente falência dos meios pré-modernos de investir a vida mortal de significação imortal. Com as outras pontes para a eternidade se desgastando e caindo em desuso, era a vez da família suportar a carga que nunca se esperou que levasse ${ }^{93}$
}

Nesse sentido, tanto a família quanto a nação seriam soluções coletivas para as angústias da mortalidade individual. Elas transmitem mensagens semelhantes: a despeito da finitude da vida, é importante que ela não seja inútil e favoreça a durabilidade de uma entidade maior que você, ou seja, não importa que você venha a perecer se deixar algo mais importante que sua existência fugaz, a saber: sua família e sua nação. Porém, atualmente constatamos que as

\footnotetext{
${ }^{92}$ ARIÈS, op.cit.

${ }^{93}$ BAUMAN, Zygmunt. EM BUSCA DA POLÍTICA. Rio de Janeiro: Jorge Zaha Ed., 2000, p. 45.
} 
sofisticadas criações da civilização ocidental (a nação e a família burguesa) já não fornecem a segurança esperada (se e que um dia de fato a forneceram):

As nações já não estão seguras no abrigo que foi a soberania política do Estado, outrora tida como garantia de vida perpétua. A soberania já não é o que costuma ser; a base de autosuficiência econômica, militar e cultural e de quase autarquia em que se apoiava foi paulatina e completamente destruída [...] As autoridades do Estado nem mesmo fingem que são capazes de ou desejam garantir a segurança dos que estão sob sua responsabilidade; políticos de todas as colorações deixam claro que, dada a severa exigência de competitividade, eficiência e flexibilidade, já ‘não podemos nos permitir’ redes de segurança coletiva. Os políticos prometem modernizar as estruturas seculares de vida dos seus súditos, mas as promessas são presságio de mais incerteza, mais insegurança e menos garantia contra os caprichos do destino ${ }^{94}$

E mais do que isso: a família também não se encontra em melhor estado - "ela parece tudo, menos um paraíso seguro e duradouro onde se possa lançar a âncora da própria existência [...] já não se pode esperar que ela dure mais do que aqueles que a criaram” ${ }^{95}$ Diante da dialética de "medos privados em lugares públicos" e "medos públicos em lugares privados", da dificuldade em reconhecer os limites das duas esferas (pública e privada) e do sentimento generalizado e não muito racional de pavor e infelicidade a alternativa indicada por Bauman é que a sociedade torne livres os seus integrantes,

[...] não apenas livres de um ponto de vista negativo - no sentido de não serem coagidos a fazer o que não fariam por espontânea vontade - mas positivamente livres, isto é, no sentido de serem capazes de fazer algo da própria liberdade, de serem capazes de fazer coisas... E isso significa primordialmente poder influenciar as condições da própria existência, dar um significado para o 'bem comum' e fazer as instituições sociais se adequarem a esse significado. ${ }^{96}$

Da família medieval à família moderna dos séculos XVIII e XIX até chegar à família contemporânea houve um longo caminho, transversalizado por revoluções burguesas, florescimento e queda de ideologias, avanços científicos e tecnológicos, quebra de paradigmas, novas concepções de Estado e expressões da vida social e política. Privacidade e individualismo passaram a ser valores cultivados por muitos, apesar de a vida pública jamais ter desaparecido e se revelar, com todas as suas contradições, nas praças, bulevares, cafés e restaurantes. Mas a família moderna, identificada como célula base da sociedade, mantenedora da moral e da ordem não passou incólume pelas transformações da história.

\footnotetext{
${ }^{94}$ BAUMAN, op.cit., p. 47.

${ }^{95}$ BAUMAN, op.cit., p. 48.

${ }^{96}$ BAUMAN, op.cit., p. 112.
} 
Com advento do século XX, as crises que eram latentes desde o fim da Idade Média se manifestaram de modo antes nunca visto nos Estados Modernos, nas sociedades em geral, e nos indivíduos, em particular. Passou-se a questionar tudo o que até então era verdade absoluta, e o turbilhão de acontecimentos desastrosos, somado à frustração diante das crenças e paradigmas até então vigentes, deu espaço à explosão de uma nova subjetividade, interpretada por muitos como “anormal”, “desviante” e “indigna”. Esta nova subjetividade, nascida da crise e do desejo de viver intensamente todos os desejos, no "pouco tempo que resta", gerou novos tipos de família.

Conjugal $^{97}$, recomposta ${ }^{98}$, de mães solteiras e seus filhos, pais solteiros e seus filhos, crianças e jovens criados pelos avós, casais heterossexuais e homossexuais com ou sem filhos, reprodução medicamente assistida, adoção legal ou informal. São várias as dinâmicas de composição de famílias nos séculos XX e XXI, e a despeito do que muitos anunciaram, esta não é uma instituição falida em vias de desaparecer, pois tem passado por reformulações para melhor atender aos anseios humanos. Mas o que leva pessoas com experiências de vida diversas a desejarem uma família? Muitas não vieram de relacionamentos frustrados? Casamentos destruídos, luto, relações afetivas conflituosas, violentas e desgastantes? Não é, aliás, a própria família a causa dos males da sociedade?

É impossível falar de família nesse começo de séculos sem nos referirmos aos novos padrões de relacionamentos, marcados por relevantes interferências de ordem interna e externa. Estas interferências, de acordo com Sarti ${ }^{99}$ dificultam sustentar a ideologia que associa a família à idéia de natureza, ao evidenciarem que os acontecimentos a ela ligados vão além das respostas biológicas às necessidade humanas e configuram diferentes respostas sociais e culturais, disponíveis a homens e mulheres em contextos históricos específicos. A autora destaca intervenções tecnológicas como a pílula contraceptiva e a reprodução assistida (inseminação artificial e fertilização in vitro) nas novas concepções e valores que se atribui à família, a maternidade e a sexualidade, e somado a isso a difusão do exame de DNA, que possibilita a identificação da paternidade. ${ }^{100}$.

Diante de tantas mudanças em curso não é mais possível falar de um "modelo de família”, ou pelo menos de um "modelo adequado", nem delimitá-la precisamente. Especialmente no que refere às famílias das classes populares, nota-se que seu perfil está muito mais para rede do que para núcleo. Prova disso são relações sociais estabelecidas com vizinhos e amigos - que passam a ser considerados parte "da família” - e as que envolvem os parentes

\footnotetext{
${ }^{97}$ Família dita convencional, constituída de pais heterossexuais e filhos.

${ }^{98}$ De segundo ou terceiro casamento, envolvendo, ou não, filhos dos casamentos anteriores com os do atual.

${ }^{99}$ SARTI, Cynthia. FAMÍLIAS ENREDADAS. In: ACOSTA, Ana Rojas et al. FAMÍLIA, REDES, LAÇOS E POLÍTICAS PÚBLICAS. São Paulo: 2005.

${ }^{100}$ SARTI, op.cit.
} 
propriamente ditos: avós, tios, tias, primos e primas em vários graus e os novos integrantes da família, como namorados (as), noras, genros, cunhados (as). Essa sociabilidade, que pudemos observar por meio das entrevistas realizadas com a família da Laura em Itapecerica da Serra e São Paulo, e da Carolina, em Porto Velho, podem ser lidas tanto pelo prisma da necessidade, quanto pelo da afetividade. Pelo primeiro podemos entender, por exemplo, o fato de Carla deixar seus filhos serem criados praticamente por sua mãe. Era imperativo que ela trabalhasse fora para ajudar no sustento da família. Pelo ângulo da afetividade - considerado por Sawaia ${ }^{101}$ como a principal força que explica a permanência da família na história - mergulhamos em complexas relações simbólicas.

Interessante notar que nas duas famílias entrevistadas o casal se desagregou. Dona Maria da Paixão expulsou o esposo de casa depois que este tentou lhe bater e porque "não cumpria suas obrigações de pai” - deixava, por exemplo, faltar o leite das crianças ${ }^{102}$. Conheceu Genival, seu primeiro esposo, quando tinha 22 anos e trabalhava na casa de um advogado, em Pinheiros. Genival era pedreiro e estava trabalhando para esse advogado. O segundo esposo, com quem ela afirma ter vivido bem a abandonou e foi embora com a vizinha.

Carla e seu esposo, no momento da gravação das entrevistas estavam separados, mas não entramos neste assunto porque entendi que ela não se sentia confortável para falar sobre ele. Soube, por sua filha Carolina, que certa vez Carla saiu de casa, levando consigo os filhos, passado um tempo retornou para sua casa, levando consigo apenas a filha mais jovem - os outros não quiseram ir. Caio, o mais velho, já morava com sua namorada e Carolina preferiu continuar morando com a avó, que lhe custeia os estudos. Maria da Paixão e Carla são evangélicas, consideram família e casamento sagrado, já enfrentaram situações de violência familiar e doméstica, não aceitam a dominação masculina, mal almejam ter um companheiro que caminhe ao lado delas e auxilie na educação dos filhos, como podemos ler no texto de Maria da Paixão:

Falei para minha família que vou me casar de novo, que quero arranjar um companheiro para eu viver junto mais uns 20 anos! Não quero ficar sozinha porque eles vão todos casar, sair de casa, viver a vida deles. [...] Quero arrumar um companheiro, mas um companheiro de Deus, evangélico, porque aí ele não vai me trazer muitos problemas, como os que tive no passado. Se não for dessa forma também não quero. Estou bem abençoada sozinha, mas se vier um servo do senhor para me ajudar a aconselhar meus filhos quando eles precisarem, vou aceitar.

A família de Carla é composta por ela, por seu ex-esposo, seu filho, suas duas filhas, sua nora e os namorados de suas filhas. O primogênito é casado e a filha do meio está noiva. Ele não

\footnotetext{
${ }^{101}$ SAWAIA, Bader. FAMÍLIA E AFETIVIDADE. In: ACOSTA, Ana Rojas. FAMÍLIA, REDES LAÇOS E POLÍTICAS PÚBLICAS. São Paulo: 2005.

${ }^{102}$ Ver texto Maria da Paixão.
} 
fala na entrevista como conheceu a esposa, mas revela sua preocupação de conseguir uma casa para morar com ela e com o filho, assim como a intenção de viver bem com a esposa e saber superar os problemas que o casal poderá enfrentar. Carol e o noivo pretendem se casar assim que conseguirem emprego fixo e uma casa. O noivado é considerado por ela como um momento importante de sua vida, e se não faz questão de contar como conheceu o namorado, faz questão de narrar sobre a ocasião do noivado:

Outra coisa importante da minha vida que gostaria de contar é sobre meu noivado com o Junior. Esse momento eu considero muito especial porque depois de três anos de namoro eu adoeci, me internaram, estive muito mal mesmo e o Junior comprou nossas alianças. Quando saí do hospital, que fui para casa, ele aproveitou a oportunidade que meu pai estava lá e conversou com ele. Meu pai ficou pensativo, falou umas coisas para a gente, deu uns conselhos e ficamos noivos, mas ainda não conseguimos nos casar porque não temos emprego nem casa. A felicidade nunca é completa [...]

Marcelo, o namorado de Camila, a irmã caçula de Carolina e Caio, é cerca de dez anos mais velho que ela, já foi casado e nas vezes que o vi, mostrou-se muito atencioso para com a namorada e a "sogra” e expressou o desejo de ter alguém a seu lado, que sonhe com ele:

A respeito de família, quero dizer que já fui casado uma vez, fiquei três anos casado e me separei. Não tive filhos, me decepcionei bastante, mas nem por isso fujo da raia... Pretendo ter uma pessoa do meu lado que sonhe comigo, se não, não tem sentido nenhum a vida.

A família de Maria da Paixão é composta de sete filhos: três do primeiro casamento, três do segundo e um de um outro relacionamento, sendo três homens e quatro mulheres. Luciana, a primeira filha, casou-se no Nordeste, com um homem natural do Piauí. Laura, a caçula do primeiro casamento também se casou com rapaz piauiense, mas o encontrou em São Paulo, na ocupação de trabalhadores sem-teto onde vive. Ambas são paulistas, mas tem o desejo de viver no Piauí, terra natal da mãe delas. Luciana tem um filho em idade escolar e o pai dele é professor. Laura, infelizmente, perdeu o seu bebê no início da gestação, mas não desistiu do desejo de ser mãe, de dar uma família a seu esposo, que demonstra tristeza por ter se criado longe da mãe e não contar com o carinho dos parentes que vivem em São Paulo. Tonho é um pedreiro habilidoso, mas às vezes passa bastante tempo desempregado.

Além dos filhos e genros, a irmã de Maria da Paixão que reside em São Paulo e as vizinhas do apartamento de frente onde mora são considerados membros da família. Já na família de Laura e Tonho, o número de agregados é bem maior e para Bárbara, que vive sozinha em seu barraco na ocupação João Cândido, o MTST inteiro é considerado sua família: 
Uma diferença da vida de fora é que todos aqui se dão, são companheiros, né? Aqui a gente cria uma família, a família é o sem-teto todo! Aconteceu alguma coisa comigo lá fora eles correm para lá.

Laura teve problemas com seus progenitores na adolescência. Um dos maiores se deu em decorrência de seu envolvimento amoroso com o esposo de uma prima de sua mãe ${ }^{103}$, quando residiu com os irmãos no Nordeste. Um episódio marcante na vida de sua família que está presente tanto em sua narrativa quando na de sua mãe e irmãos, é o de quando foi espancada pela mãe. Todos se pronunciaram acerca desse fato de modo a amenizar a imagem negativa que poderia se formar de Maria da Paixão.

Os projetos dessas famílias se organizam com base no sentimento de "ser uma família”, o que mobilizou Maria da Paixão e seus filhos na venda da casa onde moravam - único bem que possuíam - a fim de salvar a vida de um de seus membros. A partir desse momento reinicia sua saga em busca de moradia e emprego, cada um a seu modo, mas com um mesmo objetivo: casa e trabalho.

A família de Carla, apesar de possuir habilidades dimensionadas por maio grau de escolaridade e poder aquisitivo que a família de Maria da Paixão, também sofre com o problema habitacional e se une em torno do objetivo de conquistar terrenos para a construção das casas dos filhos. Nessa hora os irmãos superam suas divergências e zelam dos lotes e barracos um dos outros e Carla, a mãe, embora possua residência, ao ver a situação dos filhos, assume também a identidade de sem-teto e envolve-se intensamente na luta por moradia perpetrada pela ocupação Chico Mendes, em Porto Velho.

Ambos os projetos familiares demandam casa e espaço definido para o trabalho e esses objetos buscados aparecem nas entrevistas de forma entrelaçada. Trabalhando Maria da Paixão conseguiu construir uma casa para os pais, um pequeno palácio, se comparado à habitação onde foi criada. Com o trabalho de suas próprias mãos e o auxílio de amigos ergueu seu barraco, o mais seguro que teve à época, o que não desabou com as chuvas. Felipe acredita no trabalho realizado em emprego fixo e corretamente remunerado como meio de adquirir a tão sonhada casa. Ana Terra tem um conceito ampliado de trabalho, entende-o como tudo aquilo que é feito para a reprodução e sustento da vida, e não apenas o trabalho remunerado, o que a leva a incluir nessa categoria “os trampos de militância e as correrias do dia-a-dia”.

Para além do hábito, da conveniência, da "reprodução inconsciente” ou das pressões sociais, famílias são formadas porque vistas como um espaço potencial de realização afetiva, de vivência da integralidade do humano, de segurança e proteção. Em nossa casa e com nossa

\footnotetext{
${ }^{103}$ Ver texto Laura.
} 
família queremos "ser nós mesmos", expressar livremente nossas emoções e vontades, demonstrar nossos afetos. Em nossos parentes gostaríamos de sempre poder confiar e com eles construir projetos coletivos. Planejar viagens, planejar a compra de um bem móvel ou imóvel, organizar almoços de fim de semana para reunir, celebrar, refletir ou simplesmente "ficar próximos”.

Esse desejo de "estar junto”, essa “paixão pelo comum” que caracterizam e dão sentindo à família são indicados por Sawaia ${ }^{104}$ como elementos que deveriam ser valorizados também na esfera pública sobre a qual os Movimentos Sociais atuam, pois os projetos coletivos não podem desconsiderar o gozo individual nem exigir sacrifício remetendo a satisfação ao futuro, como é costume das religiões judaico-cristãs.

No que tange à interface urbana da esfera pública, à Cidade - destacamos que ela é assunto especialmente caro a este estudo, por ser o espaço onde as famílias colaboradoras desta pesquisa vivem e atuam politicamente.

As pessoas são movidas por diferentes anseios e expectativas, mas reunidas sobre esse terreno comum que é a cidade, desenvolvem relações orientadas e organizadas territorialmente. Sob essa ótica fica mais fácil compreender a luta por espaço na cidade, não só de espaço físico: casa, terra, áreas de lazer, mas de espaço político, de exercício da cidadania. Nessa perspectiva, as formas urbanas ganham novas dimensões e já não se associam de maneira unívoca a uma única atividade ou função, abrindo espaço para a colaboração entre os cientistas sociais e, conseqüentemente, a historicização de conceitos geográficos. ${ }^{105}$

Definir uma cidade ou “o que é cidade” requer contextualizar termos considerados autoevidentes, como "rua”, "praça” ou "prédio”, de modo que a própria cidade seja compreendida pelas pessoas e relações que a constitui, pelo tempo histórico que a molda. A partir disso, podese dizer que a práxis imprime as marcas de variadas relações culturais, políticas, econômicas, sociais, de classe e de luta por hegemonia, permitindo que se compreenda a cidade enquanto inscrição da multiplicidade. Multiplicidade de pessoas, objetos, formas, crenças, identidades, fluxos, redes, vestígios, estilos de vida e de arquitetura, tempos e temporalidades. Desse modo, entendemos cidade como uma estrutura que associa pessoas, na qual a práxis social cria e organiza espaços ${ }^{106}$

A cidade existe enquanto modo de produção, experiência, trabalho, lazer, mas também enquanto recordação de seus habitantes, e as transformações pelas quais passou ao longo dos anos, as alterações em suas formas e relações, os objetos que desapareceram e os novos que foram postos em seu lugar fazem parte da memória dos citadinos e são retomados em suas

\footnotetext{
104 SAWAIA, op.cit.

${ }^{105}$ GOMES, Paulo César da Costa. A CONDIÇÃO URBANA. Rio de Janeiro: Bertrand Brasil, 2002, p.19.

${ }^{106}$ GOMES, op. cit.
} 
narrativas. Essas narrativas expressam a cidade da infância e da juventude, a cidade onde outrora se viveu, a cidade sonhada, imaginada, desejada - que se opõe em diversos pontos à cidade real, onde se vive no momento dessa construção textual, e a cidade real, propriamente dita, onde se presencia empiricamente suas transformações e contradições.

Uma das vertentes mais tensas da relação dos colaboradores com a cidade diz respeito aos problemas habitacionais enfrentados, problema este que no Brasil, está vinculado à distribuição e uso do solo e remonta aos tempos da colonização portuguesa. Naquele período de nossa história a distribuição de terras e benefícios públicos se deu de forma a promover uma apartação social, pois a Coroa Portuguesa doava sesmarias apenas a duas classes: as da aristocracia e da burguesia, ou seja, as que possuíam capital para fazê-las produzir ${ }^{107}$. Os ricos tinham sua fazenda e sua "casa grande”, aos pobres restava a senzala e os barracos. Ao olhar por esse prisma, parece que não mudou muita coisa... Mas nosso recorte temporal para pensar os problemas decorrentes de nossos documentos não será tão amplo. Destacamos as décadas de 1950 e 1960, porque assinaladas pelos avanços da industrialização, da urbanização e da modernização da estrutura produtiva urbana. Percebemos esse período como emblemático para compreendermos os dilemas vivenciados contemporaneamente no espaço da cidade.

Os dilemas e contradições vivenciados atualmente, tanto no espaço urbano quanto no rural, manifestados nas relações entre capital e trabalho, modernidade e tradição, produção e consumo estão presentes desde o início do processo modernizador brasileiro e ganhou destaque no governo de Juscelino Kubitschek (1955-1961). Este costuma ser lembrado positivamente como um período de grande desenvolvimento econômico no qual a industrialização ganhou destaque, tendo sua força motriz concentrada nas indústrias de base e fabricação de bens duráveis e não duráveis. O preço desse processo de industrialização: as conseqüências sociais e políticas da abertura nacional ao capital estrangeiro nem sempre são levadas em conta.

Os ideais de modernidade e modernização que nortearam a política do período ainda encantam e parecem sublimar ou maquilar os efeitos negativos do processo. Eles ainda se fazem presente em nosso meio, apesar de nossa sociedade há muito se considerar "moderna” e “urbana”. De acordo com Schwartzman, o motivo pelo qual os conceitos de modernidade e modernização "se recusam a ir embora, e sempre reaparecem, é que as esperanças, promessas e frustrações que trazem consigo estão tão presentes hoje quanto estiveram há séculos, e não podem ser deixados de lado quando tentamos entender as questões de pobreza, exclusão social e suas conseqüências no mundo contemporâneo" ${ }^{\text {,108. }}$

Como não é recomendado julgar uma época pelo que ela pensa de si mesma - ainda

${ }^{107}$ GORENDER, Jacob, REGIME TERRITORIAL NO BRASIL ESCRAVISTA, In: A questão Agrária no Brasil: o debate na esquerda: 1960-1980, p. 203.

${ }^{108}$ SCHWARTZMAN, Simon. POBREZA, EXCLUSÃO SOCIAL E MODERNIDADE: UMA INTRODUÇÃO AO MUNDO CONTEMPORÂNEO. São Paulo: augurium editora, 2004. 
que essa época seja a nossa - buscamos conhecer seu percurso histórico até o momento atual. Não temos a pretensão, neste texto, de discutir em grandes linhas o processo de industrialização e a modernidade urbana, contudo, estas se mostram questões inescapáveis quando se tem em vista a cidade, as ocupações de trabalhadores sem-teto e as periferias, de um modo geral.

Entendemos que o processo modernizante orquestrado pelo Estado promoveu uma industrialização que favoreceu o deslocamento de grandes levas de camponeses para os centros industriais. Esses trabalhadores viam naquele espaço uma oportunidade para empregarem sua força de trabalho, melhorar suas condições de vida e desfrutarem dos benefícios da modernidade. Muitos desses trabalhadores que se deslocaram para as cidades saíram da zona rural. Em contrapartida, os latifundiários rurais re-acomodaram seus interesses: a estrutura fundiária foi mantida e a mecanização da agricultura assegurou a produção e o lucro aos quais estavam acostumados. De acordo Iokoi, essa acomodação de interesses remete a um caráter de continuidade, de não-ruptura com o projeto colonial e de não-desvinculação do rural com o urbano:

Não há, na História brasileira, uma distinção e uma separação entre esses dois níveis da vida social. Desde o início, com a manutenção da economia monocultora de exportação, a inter-relação rural-urbano é definida no urbano sobre o rural, e este nível vive exatamente os dilemas de um projeto de modernização que se assenta nas estruturas coloniais e latifundiárias. Não houve rompimento entre esses dois grupos e sim uma acomodação. ${ }^{109}$

Ao tratar da dialética do rural e do urbano, Queiroz aponta para o sentido filosófico dessa interação:

\begin{abstract}
Existe uma dualidade do rural e do urbano, no sentido filosófico específico do termo 'dual', que exprime a existência, lado a lado, de dois termos que, embora interagindo, são absolutamente irredutíveis um ao outro; 2) o rural é conhecido como ‘atrasado’ em sua evolução, em relação ao urbano, e sua influência sobre este é tida como 'sobrevivência tradicional'; 3) a penetração de elementos urbanos no campo 'inovações’ - passa a ser imediatamente considerada como um avanço ‘benéfico’ para este; 4) aumentando cada vez mais a penetração, vão se perdendo as características peculiares à sociedade rural, que tende a se confundir cada vez mais com a sociedade urbana, e, portanto, a desaparecer. ${ }^{110}$
\end{abstract}

\footnotetext{
${ }^{109}$ IOKOI, Zilda Márcia Gricoli, Os dilemas históricos da questão agrária no Brasil, In: Terra Livre, publicação da Associação Brasileira de Geógrafos, n. 11/12, p. 138.

${ }^{110}$ QUEIROZ, Maria Isaura Pereira de. DIALÉTICA DO RURAL E DO URBANO: EXEMPLOS BRASILEIROS. In: BLAY, Eva Alterman (org.). A Luta pelo Espaço. Petrópolis: Ed. Vozes, 1979.
} 
A tendência de desaparecimento das características da sociedade rural, apontada por Queiroz também pode ser interpretada como uma recriação e re-alocação em outro espaço, a saber, o urbano. Essas características podem ser encontradas em uma valorização da vida campestre - muitas vezes idealizada - em um apreço por um “modo de vida simples”, sem muita parafernália tecnológica por perto e baseado em uma alimentação frugal, e mesmo nas redes de solidariedade estabelecidas pelas famílias das classes laboriosas nas periferias urbanas - que engloba a partilha de alimentos, o incentivo para se adaptar e permanecer no novo lugar, e sofisticadas significações culturais. Muitas dessas famílias se deslocaram do campo, atraídas pela concentração de capital e de mercado de trabalho que a cidade representava. No que tange à região Sudeste, importante pólo de atração desses trabalhadores, o par industrializaçãomodernização acabou por aguçar os desequilíbrios econômicos entre as regiões e elevar os fluxos migratórios para a área. Para Blay,

\begin{abstract}
A busca de empregos, da renda ou da mera subsistência significava para o trabalhador uma forma de liberdade - a liberdade do proprietário da força de trabalho que pode dispor dela livremente no mercado - a qual corresponde, no novo contexto histórico, à liberdade que o servo obtinha quando fugia dos senhores da terra e se abrigava na cidade $^{111}$
\end{abstract}

Essa "liberdade” se viu interditada na medida em que o mercado de absorção da força de trabalho se viu em retração, dado a conjuntura do país, que tornou dificultosa a reprodução do capital. O resultado dessa crise tem sido uma oferta excessiva da força de trabalho, ou seja, desemprego, subemprego, crescimento da economia informal e da marginalidade social. Nas palavras de Kowarick:

Ao que tudo indica, a evolução do capitalismo latino-americano, quando comparada à história trilhada pelos países desenvolvidos, parece ser marcada por fenômenos distintos no que tange a marginalidade. De um lado, a absorção de mão-de-obra em atividades caracteristicamente capitalistas é quantitativamente diminuta Em outros termos, o capitalismo da Região desenvolve-se transformando pequena parcela da força de trabalho em trabalhadores assalariados: ao se desenvolver, libera parte da mão-de-obra vinculada às relações de produção 'tradicionais', que não consegue se transformar em assalariada. Mas esta ‘liberação’ não é aleatória. Ela é criada com a intensificação do processo industrial, dando origem a vastas parcelas de mão-de-obra que passam a operar sob 'novas' relações de produção ‘arcaicas', presentes em boa parte das atividades integrantes do setor terciário da economia: de modo especial, as ocupações autônomas do comércio de mercadorias, os pequenos serviços de reparação e manutenção e os empregos domésticos remunerados,

\footnotetext{
${ }^{111}$ BLAY, Eva Alterman (org.). A LUTA PELO ESPAÇO. Petrópolis: Ed. Vozes, 1979. p.15.
} 
além dos desempregos, das várias formas de subemprego e trabalhadores ocasionais ou intermitentes, que caracterizam o cenário urbano de trabalho das sociedades latinoamericanas. ${ }^{112}$

O fato é que a estratégia desenvolvimentista adotada no Brasil não foi capaz de absorver totalmente a ampla parcela da população oriunda da zona rural e nem mesmo a que já vivia na zona urbana, acentuando o fenômeno da marginalidade. A vivência desse deslocamento do processo produtivo, dessa marginalidade colocou em curso as lutas no campo e na cidade. Como nesse estudo privilegiamos essa última formação espacial (a cidade), passamos a delinear sua nova paisagem.

Para aproveitar a idéia de "deslocamento”, e “marginalidade, gostaríamos de iniciar com a questão da centralidade urbana e seu “posicionamento”, seu movimento dialético específico. Trata-se de uma centralidade que, nas palavras de Lefebvre, “se impõe”, pois não existe realidade urbana sem centro, quer se trate do centro comercial, que reúne produtos e coisas, do centro simbólico, que reúne significações, do centro de informação e decisão, e todo centro se auto-destrói, seja por saturação: porque remete a uma outra centralidade; seja por exclusão: por expulsar para a periferia aqueles que exclui. ${ }^{113}$ Se entendermos centro como local de “concentração do capital” não fica difícil entender porque ele atrai e expulsa os trabalhadores. À proporção que necessita de seus serviços, de sua capacidade de trabalho, de criação, ele atrai os trabalhadores. Satisfeitas suas necessidades, ele os expulsa para a periferia, que representa muitas vezes o único local possível para esses trabalhadores viverem, construírem uma casa, desfrutarem de alguma atividade de lazer, reproduzirem as relações de produção, que são relações de classe.

\footnotetext{
${ }^{112}$ KOWARICK, Lúcio. CAPITALISMO E MARGINALIDADE NA AMÉRICA LATINA. Rio de Janeiro: Ed. Paz e Terra, 1977. p.60.

${ }^{113}$ LEFEBVRE, Henri. ESPAÇO E POLÍTICA. Belo Horizonte: Ed. UFMG, 2008, p.85-86.
} 


\section{CARTOGRAFIAS URBANAS}

Partindo do pressuposto de que a leitura dos espaços urbanos, periféricos e centrais, não se faz somente sobre mapas, construindo um código abstrato, mas que essa leitura é por excelência "sintomal" 114, colocamo-nos em busca do que apresenta e de seus significados. Primeiramente cabe refletirmos sobre como as periferias urbanas se mostram, quais suas configurações, em seguida, o que são, o que revelam e por que.

Ao caminhar por periferias de Porto Velho, Itapecerica da Serra e São Paulo, com um olhar mais atento do que costumo ter em meu cotidiano de travessias na cidade - onde faço também o caminho centro-periferia, periferia-centro -, foi possível notar que estas se mostram afastadas dos centros de decisões da cidade e apresentam infra-estrutura precária. As moradias, na maioria das vezes são contíguas umas às outras, pouco espaçosas e inacabadas. Algumas parecem ser inseguras, incapazes de resistir a alterações climáticas as mais previsíveis, como chuvas fortes. Telefones públicos, pavimentação, saneamento básico, escolas, postos de saúde, quando existem nesses "bairros”, não funcionam de modo satisfatório. É comum nos depararmos nesses lugares com telefones que não fazem ligação, pavimentação insuficiente, saneamento básico inexistente, escolas que não ensinam, postos de saúde que não curam e não previnem.

Periferia é uma categoria de matriz geográfica que costuma ser pensada na dialética da cidade: centro/periferia, capital/trabalho. A classe de menor poder econômico ao ver-se impossibilitada de adquirir uma residência nos bairros centrais ou a ele adjacentes, e mesmo de pagar o alto preço dos aluguéis muda-se para regiões distantes. Na maioria das vezes trata-se de áreas de risco, na encosta de morros ou junto a córregos, distante do local de trabalho e da infraestrutura adequada a uma vida com qualidade. Distante das boas escolas, dos bons hospitais, dos espaços de lazer.

São nessas regiões afastadas do núcleo de concentração do capital, dos serviços e do "lazer sofisticado" que os bairros dos pobres são construídos, diferente do que acontece, por exemplo, nas periferias da Europa e dos Estados Unidos, onde esses bairros são denominados “subúrbio”. Lá as áreas periféricas são as preferidas da classe média e alta e as centrais tornamse habitadas pelos pobres e minorias étnicas. Nos dois casos percebemos uma segregação social manifesta no distanciamento em nível territorial.

Como o capital é móvel, hoje em dia já não se pode falar de uma única centralidade ${ }^{115} \mathrm{e}$ conseqüentemente, de uma única periferia. Percebemos, inclusive, o crescente interesse do capital se direcionando para as áreas periféricas, onde terrenos são adquiridos e permanecem

\footnotetext{
${ }^{114}$ LEFEBVRE, op.cit., p.85.

${ }^{115}$ A esse respeito ver o livro de Heitor Frúgoli Junior: CENTRALIADE EM SÃO PAULO: TRAJETÓRIOS

CONFLITOS E NEGOCIAÇÕES NA METRÓPOLE. São Paulo: EDUSP, 2000.
} 
inutilizados até sua “valorização”. Atualmente notamos condomínios de luxo erigidos na periferia, contudo, estes se relacionam o mínimo possível com o seu entorno, porque foram construídos para ser uma espécie de “ilha auto-suficiente”, com segurança própria, academia de ginástica, salão de beleza, cinema, creche, cursos de idiomas. E o que vier a faltar pode ser pedido por telefone ou via Internet. Caldeira os caracterizou como “enclaves fortificados”. ${ }^{116}$

Apesar de se localizarem em zona periférica, esses novos residenciais se diferenciam da vida que o circunda por sua estrutura e nomes elegantes. Jamais assume o nome do bairro, o signo da “quebrada”. É sempre o “jardim”, o “parque”, o “paraíso ecológico ou tropical” a “menos de X minutos” dos melhores restaurantes, aeroportos, bancos e escritórios. Contudo, esta não é a paisagem dominante nas periferias. O que mais se vê são casas inacabadas, sustentadas pela parede do vizinho ou pela encosta do morro, campinhos de futebol e singelos templos evangélicos. Edificações que de tanta dificuldade para serem feitas, já nascem com semblante de velhas. De acordo com José Moura Gonçalves Filho,

A visão dos bairros pobres parece, às vezes, ainda mais impiedosa do que a visão de ambientes arruinados: não são bairros que o tempo veio corroer ou as guerras vieram abalar, são bairros que mal puderam nascer para o tempo e para a história. Um bairro proletário não é feito de ruínas. Ocorre que ali o trabalho humano sobre a natureza e sobre a cidade parece interceptado [...] No bairro pobre, menos de ruína, o espetáculo mais parece feito de interrupção -, as linhas e as formas estão incompletas, não puderam se perfazer. Os meios, os recursos, sobre os quais o homo faber investe o seu poder inventivo, foram perdidos ou nunca foram alcançados: o resultado destas carências e frustrações é que os poderes mesmos da fabricação humana ficam perdidos ou nunca são alcançados - lançam-se em situações sem suporte, gastam-se no ar, sem resposta, são neutralizados. Faltam os instrumentos, faltam os materiais que suportariam o trabalho humano para a configuração de um mundo, para a fisionomia de uma cultura. Gradualmente, chega a faltar o animus faber ${ }^{117}$.

Tudo é difícil para o habitante da periferia: o deslocamento para o trabalho ou para o desfrute de um momento de descanso, o pagamento do aluguel e dos encargos públicos, a construção da casa própria, as humilhações e preconceitos vivenciados no dia-a-dia. Como resistência a esse processo que os aparta tanto da esfera pública quanto da esfera privada ${ }^{118}$ e na tentativa de se manterem minimamente integrados (trabalhando, consumindo), criam espaços de sociabilidades específicas: a casa sempre em construção, o campo de futebol, o bar onde o grupo

\footnotetext{
${ }^{116}$ CALDEIRA, Teresa. CIDADE DE MUROS. São Paulo: Ed. 34/EDUSP, 2000.

${ }^{117}$ GONÇALVES FILHO, José Moura. HUMILHAÇÃO SOCIAL: UM PROBLEMA POLÍTICO EM PSICOLOGIA. São Paulo: Psicologia USP, vol. 9, nº 2, 1998.

${ }^{118}$ Esses sujeitos são apartados dos espaços de decisão política e da vivência da intimidade. Passam a maior parte do tempo no trabalho, realizando tarefas alienantes, ou em trânsito entre o local de residência e o do emprego.
} 
de pagode do bairro pode falar do amor e suas decepções, a festa onde os meninos MCs daquela e de outras periferia podem encontrar receptores para seus protestos.

A periferia é um espaço que só será bem compreendido se levado em conta as relações sociais e expressões culturais que apresenta, e para isso, é preciso mais do que um olhar absorto em seus caracteres “exóticos” e em sua “capacidade de adaptação à realidade”. É necessário compreender os limites dessa segregação social, bem como seus vínculos com a regressão nos investimentos públicos e a gestão discriminatória da regulação e uso do solo. Outro fator que é preciso considerar nesse processo produtor de segregação social e espacial, é a urbanização. Esta, de acordo com Milton Santos ${ }^{119}$ ganhou destaque no Brasil a partir de meados do século XX, com alterações na base de nossa economia: incentivo à industrialização e declínio da produção agro-exportadora de café. Urbanização e industrialização caminhavam lado a lado e pareciam representar uma porta de saída para a independência de séculos de dominação da produção agrária, todavia, "a evolução dos acontecimentos mostrou que ao lado de intenso crescimento econômico (7\% em média entre 1940 e 1980), o processo de urbanização acarretou em crescimento da desigualdade e em uma gigantesca concentração espacial da pobreza” ${ }^{120}$.

Trabalhos como o do geógrafo Milton $\operatorname{Santos}^{121}$ e dos arquitetos Nestor Goulart Reis Filho $^{122}$, João Sette Whitaker Ferreira ${ }^{123}$ e Ermínia Maricato ${ }^{124}$ apontam para as especificidades da urbanização do Brasil no século XX. Se por um ângulo esse fenômeno é visto positivamente, como necessário para o crescimento do país, já que apto a atrair investimentos e gerar “oportunidades de emprego", por outro é considerado responsável pelo acirramento das desigualdades sócioeconômicas, das disparidades entre as regiões e as habitações de ricos e pobres, pelo aumento das periferias.

${ }^{119}$ SANTOS, Milton. A URBANIZAÇÃO BRASILEIRA. SÃO PAULO: EDUSP, 2005.

120 MARICATO, Ermínia. A BOMBA RELÓGIO DAS CIDADES BRASILEIRAS. In: (URL: http://www.usp.br/fau/depprojeto/labhab/04textos/exclusao.doc)

${ }^{121}$ SANTOS, Milton. O ESPAÇO DO CIDADÃO. São Paulo: EDUSP, 2007.

122 REIS FILHO, Nestor Goulart. NOTAS SOBRE URBANIZAÇÃO DISPERSA E NOVAS FORMAS DE TECIDO URBANO. São Paulo: Via das Artes, 2006. (org.) BRASIL: ESTUDOS SOBRE DISPERSÃO URNANA. São Paulo: FAU-USP, 2007, vol. 1.

${ }^{123}$ FERREIRA, João Sette Whitaker. GLOBALIZAÇÃO E URBANIZAÇÃO SUBDESENVOLVIDA. São Paulo: Rev. São Paulo em Perspectiva, vol. 14, nº 04, 2000.

${ }^{123}$ MARICATO, Ermínia. URBANIZAÇÃO NO BRASIL: A MODERNIZAÇÃO EXCLUDENTE. São Paulo: Família Cristã, vol. 3, 2001 URBANISMO NA PERIFERIA DO MUNDO GLOBALIZADO: METRÓPOLES BRASILEIRAS. São Paulo: Rev. São Paulo em Perspectiva, vol. 14, nº 04, p. 21-33, 2000.

${ }_{124}$ DURHAM, Maria Eunice. A SOCIEDADE VISTA DA PERIFERIA. In: (URL: http://www.anpocs.org.br/portal/publicacoes/rbcs_00_01/rbcs01_07.htm).

${ }^{124}$ KOWARICK, Lucio. A ESPOLIAÇÃO URBANA. Rio de Janeiro: Paz e Terra, 1993. 
O crescimento da periferia no Brasil é sintomático de uma urbanização desigual, cujas intervenções estéticas são realizadas majoritariamente em áreas de grande visibilidade, concentração do capital e interesses do Estado. De acordo com Eunice Maria Durham,

\begin{abstract}
A população pobre está em toda a parte nas grandes cidades. Habita cortiços e casas de cômodos, apropria-se das zonas deterioradas e subsiste como enclaves nos interstícios dos bairros mais ricos. Mas há um lugar onde se concentra, um espaço que lhe é próprio e onde se constitui a expressão mais clara de seu modo de vida. É a chamada periferia [...] formada pelos bairros mais distantes, mais pobres, menos servidos por transporte e serviços públicos. ${ }^{125}$
\end{abstract}

Essa população pobre, ao se deslocar de seus estados de origem em busca de trabalho e melhores condições de vida, levava consigo o sonho da casa própria, que se tornou uma

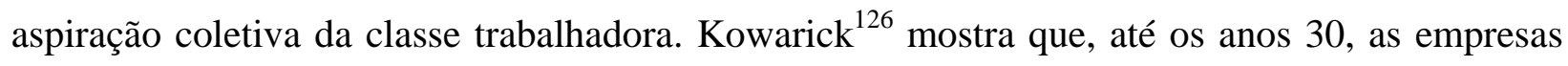
resolviam parcialmente o problema habitacional dos trabalhadores por meio da construção de vilas operárias. Isso era viável na medida em que a quantidade de força de trabalho a ser alojada ainda era pequena, mas com a intensificação do processo de industrialização, o número de trabalhadores aumentou, bem como a pressão sobre a oferta de habitações populares. Diante disso, as empresas transferiram para o Estado o dever de fornecer moradia aos trabalhadores, as vilas operárias tenderam a desaparecer e a questão da moradia passou a ser resolvida pelas relações econômicas no mercado imobiliário.

Na impossibilidade de comprar ou alugar uma casa nas áreas nobres da cidade, e na falta de financiamentos e alvarás para a construção - concedidos apenas a terrenos legalmente documentados foi preciso que as famílias trabalhadoras construíssem suas moradias nos bairros distantes e com sérios problemas infra-estruturais. Como as condições econômicas não são favoráveis a essa classe, o trabalho de construção das casas pode levar anos para ser concluído. Mas esta não é a única face da segregação, ela ainda se mostra em seu perfil social: essas pessoas apartadas geograficamente do resto da cidade também têm distantes suas condições de acesso a cidadania. Entendemos que a cidadania expressa um conjunto de direitos que dá à pessoa a possibilidade de participar ativamente da vida e do governo de seu povo. Quem não tem cidadania está marginalizado ou excluído da vida social e da tomada de decisões, ficando numa posição de inferioridade dentro de seu grupo social ${ }^{127}$.

Entendemos que as famílias colaboradoras deste estudo, assim como os demais habitantes das periferias urbanas, estão em busca da cidadania. Os lugares que habitam: casas, apartamentos

\footnotetext{
${ }^{125}$ DURHAM, Maria Eunice. A SOCIEDADE VISTA DA PERIFERIA. In: (URL: http://www.anpocs.org.br/portal/publicacoes/rbcs_00_01/rbcs01_07.htm).

${ }^{126}$ KOWARICK, Lucio. A ESPOLIAÇÃO URBANA. Rio de Janeiro: Paz e Terra, 1993.

${ }^{127}$ DALLARI, Dalmo de Abreu. DIREITOS HUMANOS E CIDADANIA. São Paulo: Ed. Moderna, 1998.
} 
ou barracos de ocupações de trabalhadores sem-teto estão postos em periferias urbanas, são desses lugares que eles falam, que partilham conosco suas experiências e ideais de cidade. Isto nos levou a pensar a periferia "no contraponto entre estar fora e estar dentro da cidade". De acordo com Rodrigues e Brito, “normalmente, a periferia é pensada como a borda, o limite entre o fora e o dentro. Estar na periferia é estar distante, na coincidência entre a distância espacialmente considerada e a distância politicamente imposta. É estar fora do centro do poder de decisão" ${ }^{\prime 28}$. Os bairros pobres que se formam a cada dia, as ocupações do MTST e do Movimento dos Trabalhadores Sem-teto de Rondônia, ao mesmo tempo em que constituem a condição primordial para que essas famílias se incluam na vida urbana da sociedade, são, em muitos casos, a única maneira de estar na cidade. Esse “estar na cidade”, como vimos, é contraditório: significa situar-se em seu espaço, mas não fazer parte dela, ser o seu refugo.

Bauman analisou o fenômeno do refugamento humano no âmbito da modernização destacando a questão do trabalho na contemporaneidade. Nosso tempo reflete uma modernização que progrediu triunfante, alcançando as partes mais remotas do planeta. A quase totalidade da produção e do consumo se tornou mediada pelo dinheiro e pelo mercado, a mercantilização e monetarização dos modos de subsistência penetraram os recantos mais longínquos, por isso, não se dispõe mais de soluções globais para problemas produzidos localmente, tampouco de escoadouros globais para excessos locais ${ }^{129}$. A vitória global da modernização tem como um de seus aspectos o número alarmante de refugo. A produção e o consumo excessivos, os resíduos a serem eliminados, o desperdício e o desejo insano de consumir o novo (que amanhã já será obsoleto), têm acarretado em uma sensibilidade desatenta e descompromissada com o próximo e com a vida na Terra.

Se num primeiro estágio a Modernidade produziu “exército de reserva”, desempregados com a expectativa de logo retomarem seus postos no mundo do trabalho, esse segundo estágio produz pessoas refugadas, colocadas na condição de excesso, de redundância, sem grandes convicções e oportunidades de se re-inserirem na sociedade. Elas estão presentes, mas como lixo, como seres descartáveis que já não tem utilidade. Bauman refere-se a essas pessoas como "vidas desperdiçadas”, de fato o são, pois não estão livres para desenvolver suas potencialidades, mas mais do que isso, diria que são “vidas sacrificadas”, pois é sobre elas que se sustenta o bem-estar dos que se beneficiam do progresso econômico e das vantagens de ser in.

Às pessoas refugadas ou em vias de entrar nesse processo, restam três alternativas: resignar-se, deixando as coisas seguirem seu fluxo, buscar individualmente soluções para os problemas que as atingem, e que como sabemos, não são individuais, mas de ordem social, ou buscar coletivamente a solução. Ao que parece, a última alternativa é a que pode produzir mais

\footnotetext{
${ }^{128}$ RODRIGUES; BRITO. Op.cit., p.52.

${ }^{129}$ BAUMAN, op.cit., p.13.
} 
efeitos positivos, já que a ação coletiva pressupõe uma vida em comunidade, ou pelo menos um conhecimento acerca desta, memória e princípios partilhados. Aí já não se está sozinho e as forças se multiplicam, visto que "ser abatido como 'baixa colateral' do progresso econômico, agora nas mãos de forças globais livremente flutuantes, não é uma sina que os governos dos Estados possam prometer afugentar com alguma fidedignidade» ${ }^{130}$ Se o Estado não pode assegurar os direitos sociais, sobra apenas um caminho: o de construção de uma democracia, no sentido etimológico do termo, e tal ação não pode prescindir de uma reconstrução dos direitos humanos.

Piovesan ensina que:

“No momento em que os seres humanos se tornam supérfluos e descartáveis, no momento em que vige a lógica da destruição, em que cruelmente se abole o valor da pessoa humana, torna-se necessária a reconstrução dos direitos humanos, como paradigma ético capaz de restaurar a lógica do razoável.

Contemporaneamente, é preciso destacar que centros e periferias se movem. No caso de São Paulo, por exemplo, observamos um retorno dos menos afortunados ao seu centro histórico o que demonstra a circulação do capital e a fluidez dos interesses imobiliários que dia-a-dia estabelecem novas periferias. Desse modo, compreendemos a periferia para além de seu sentido geográfico, ou seja, de um afastamento em relação ao centro, como um processo constante de exclusão/luta por integração na cidade, marcado territorialmente. Vivendo essa exclusão, as colaboradoras deste estudo têm elaborado estratégias tanto para a sobrevivência cotidiana quanto para a transformação da estrutura social, como pudemos ver nas histórias de vida aqui registradas.

Se a crise urbana que presenciamos hoje tem raízes em processos antigos como o da industrialização e modernização nacional, e no próprio desenvolvimento do capitalismo na América Latina, como salientou Kowarick ${ }^{131}$, nos perguntamos: o que mudou? O que há de novo nisso tudo? Os fatores que assinalam a crise urbana já estavam presentes em períodos anteriores, mas neles podiam ser "escamoteados através de uma pseudoliberdade de integração à sociedade de consumo" ${ }^{132}$. A diferença encontra-se justamente no agravamento desses problemas, à medida que aumentam o desemprego e a queda do valor do salário. A esperança e a luta por transformar esses quadros subsistem, mas já não se tem a convicção de que se trata de uma crise passageira, de que logo ela vai passar e todos terão um lugar na cidade.

No encalço das contradições que se avolumam no espaço urbano, novos Movimentos Sociais têm aparecido e articulado ações contra as políticas deteriorantes dos padrões de vida na cidade. A deterioração desses padrões de vida - que nunca foram lá muito elevados para a classe

\footnotetext{
${ }^{130}$ BAUMAN, op.cit., p.112.

${ }^{131}$ KOWARICK, op.cit.

${ }^{132}$ BLAY, op.cit., p.16.
} 
trabalhadora, para os escravos, os imigrantes, e os trabalhadores assalariados -, tem se tornado mais intenso à medida que o Estado posiciona-se favoravelmente ao grande capital, fornecendo a infra-estrutura e os insumos necessários para que ele possa multiplicar seus excedentes, em detrimento das demandas populares. O resultado dessa parceria entre Estado e capital é o aumento da espoliação urbana, a queda dos salários e do poder de compra e a precariedade ou falta de bens de uso coletivo, como escolas e meios de transporte. A existência desses problemas, não é por si só, suficiente para criar Movimentos Sociais - se fosse assim todos os que tomam ônibus e trens lotados ou não possuem casa própria estariam participando de algum -, mas a tomada de consciência desses problemas e a crença de que “um outro mundo é possível” é deflagrador do projeto de mudança que esses movimentos ensejam.

A periferia, para os militantes desses Movimentos Sociais tem um caráter especial, de transformação da sociedade, de luta e significa comunidade. Marcos narra:

\begin{abstract}
Domingo passado um cara falou: “O time da favela ta jogando bem!” Eu falei: "Time da favela, não! Comunidade João Cândido! Não é favela, a gente já luta para acabar com favela, não vou aceitar essa palavra! É Comunidade João Cândido, Periferia, que é diferente!” Prefiro estar aqui dentro e ver a vida de cada um do que estar dentro do meu carro ou do meu apartamento isolado, com medo de sair na rua, porque os presos hoje são as classes média e rica, que ficam trancadas em suas casas, em seus condomínios, com medo de sair para comprar um pão, comprar crédito para o celular, nós não!
\end{abstract}

\title{
Produção e Apropriação do Espaço Urbano
}

Dentre os sujeitos produtores do espaço urbano, se destacam as famílias em busca de moradia, os detentores dos meios de produção, os agentes imobiliários e o Estado. No espaço urbano estão presentes camadas de vários tempos, do passado, do presente, do futuro que se deseja construir... Virtualidades, crenças que se cristalizam nos objetos geográficos e arquitetônicos com os quais nos relacionamos e que trazem consigo indícios de ideais, concepções estéticas e políticas, lutas de classes.

Ao produzi-lo, seus construtores projetam nele seu sistema de crenças. De acordo com Milton Santos os construtores do espaço não se desembaraçam da ideologia dominante quando concebem uma casa, uma estrada, um bairro, uma cidade. O ato de construir está submetido a regras que procuram nos modelos de produção e nas relações de classe suas possibilidades atuais. $^{133}$.

Com o avanço do capitalismo o urbano tem passado por inúmeras transformações, a saber:

\footnotetext{
${ }^{133}$ SANTOS, Milton. op.cit., p. 24.
} 
a) De pequenas, algumas cidades tornaram-se metrópoles densamente povoadas e populosas, que não conseguem atender as demandas dessa população crescente. Essa situação é reflexo, dentre outras coisas, do êxodo rural, também provocado pelo avanço do capitalismo sobre as zonas rurais. Novas tecnologias passaram a substituir em grande parte a mão-de-obra camponesa e mostram-se mais adequadas aos novos interesses mercantis (produção em larga escala, monocultura).

b) A cidade passou a ser mercadoria e seu solo, objeto de especulação imobiliária. Além de grande número de terrenos urbanos ficarem ociosos, aguardando valorização, os que estão disponíveis para comercialização tornam-se tão caros a ponto de serem inacessíveis a determinados segmentos da classe trabalhadora.

c) Com o encarecimento do solo e a gentryfication de determinadas áreas, as classes populares são obrigadas a se deslocar para as periferias, frequentemente lugares distantes do centro da cidade (ou dos centros), distantes de seus locais de trabalho e com sérios problemas infra-estruturais. Enquanto as classes populares são expulsas das áreas centrais e nobres da cidade, as classes média e alta se deslocam também para regiões distantes e constroem nelas “enclaves fortificados” ${ }^{34}$, como condomínios fechados de luxo, que contam com excelente infraestrutura (alguns já possuem até escola) e considerável rede de serviços, como academias de ginástica, salões de beleza, clínicas de estética e lojas de conveniências.

d) Mas não foi só o solo urbano que se tornou mercadoria. A cidade como um todo passou a ser tratada como tal. A substituição do valor de uso pelo de troca atribuiu à ela novo sentido: ela não é mais considerada lugar para se habitar, mas um “ambiente visual”. Segundo Barbosa $^{135}$ é nessa direção que se investe e se revestem as cidades com design clean do mobiliário urbano destinado a modernizar/disciplinar o uso mercantil da paisagem, por meio de concessão de espaços públicos a corporações privadas. Prefeituras de diversas cidades passam, então, a recortar áreas da cidade e ceder aos interesses das firmas de design urbano, e como contrapartida da criação, instalação e manutenção dos objetos criados, as empresas podem fazer uso do "espaço" para fins publicitários. Assim, sob o primado da circulação de imagens, a cidade é convertida em um capital móvel do consumo seletivo e de massa.

e) A segregação social resultante do processo de comercialização da cidade - separação entre os que podem consumir em demasia, os que consomem apenas o mínimo vital e os que consomem apenas as sobras dos outros, tornando-se eles próprios refugo humano - potencializa a cidade enquanto palco da luta de Movimentos Sociais que visam superar as contradições, desigualdades e prejuízos causados pelo Capitalismo, enquanto modo de produção dominante.

\footnotetext{
${ }^{134}$ CALDEIRA, op.cit.

135 BARBOSA, Jorge Luis. A CIDADE CAÓTICA: IDEOLOGIA E SIMULAÇÃO DA CRISE A SOCIEDADE URBANA. In: GEOUSP Espaço e Tempo, 2001, $\mathrm{n}^{\circ} 10$.
} 


\section{O MTST e a Reforma Urbana}

O Movimento dos Trabalhadores Sem-teto (MTST) nasceu em São Paulo em 1997 e tem como substrato as experiências das $\mathrm{CEBs}^{136}$ - que orientam a vida das ocupações por meio dos momentos de mística e reflexão -, as experiências das marchas nacionais realizadas pelo MST que ao caminhar por diversas cidades tomou nota dos problemas urbanos e incentivou e assessorou um novo projeto de luta -, bem como as experiências das associações de moradores, que o MTST expressa por meio da APA ${ }^{137}$. Este novo Movimento está presente em quase todo o Estado de São Paulo, se articula com sindicatos, Associações e com outros Movimentos Sociais urbanos. Tem como uma de suas metas se expandir por todo o território nacional e iniciativas têm sido tomadas nessa direção, como o apoio aos movimentos por moradia dos diversos Estados e a organização de atos a serem realizados simultaneamente em diversas cidades do país. Esse projeto pessoal de expansão é questionado por alguns militantes, que acreditam ver aí "um passo largo demais para o momento e que pode prejudicar as lutas que foram iniciadas na grande São Paulo e no Rio de Janeiro”. Outros o apóiam e ressaltam a necessidade de transcender práticas "bairristas”.

O MTST organiza-se por meio de “coletivos”"138, que executam tarefas indispensáveis ao funcionamento das ocupações e ao progresso do próprio Movimento.

Promove ocupações de terras devolutas e que não cumprem sua função social, passeatas e atos em praças públicas ou em prédios do Governo. As ocupações são feitas mediante acampamentos, que contam com brigadas ${ }^{139}$, equipamentos de uso coletivo, como torneiras e tonéis de armazenamento de água, cozinha, espaços para lazer, pátio para reuniões e Ciranda ${ }^{140}$, além, é claro, dos barracos confeccionados com madeirite, madeira e lona. Na maioria das vezes esses pequenos barracos, medindo aproximadamente 4X4, abrigam famílias numerosas, mas também há barracos de pessoas solteiras, que vivem sozinhas naquele espaço, ou que decidem

${ }^{136}$ CEBs: Comunidades Eclesiais de Base, comunidades ligadas à Igreja Católica que incentivadas pelo Concílio Vaticano II se espalharam pelo Brasil nas décadas de 1970 e 1980 e atuaram na luta pela redemocratização e contra o "pecado social”, ou seja, a injustiça estrutural ocasionada pelo modelo socioeconômico e político vigente na América Latina.

${ }^{137}$ Associação Periferia Ativa: é uma associação de comunidades que visa organizar a luta do povo pobre das periferias das cidades a fim de “construir o poder popular e através dele, uma nova sociedade”.

${ }^{138}$ Grupos responsáveis pela realização de tarefas como a comunicação social e relação com a imprensa, a educação escolar, a promoção de atividades culturais e de lazer e a construção da infra-estrutura dos acampamentos.

139 Espécie de "bairros" que compõem os acampamentos. Essas brigadas costumam ser batizadas com nomes de homens e mulheres considerados revolucionários e tem como obrigação zelar pela área que ocupam, tanto no que diz respeito à limpeza e conservação das estruturas construídas, quanto no incentivo e animação dos acampados que se encontram desanimados. Essas brigadas, em dias de saraus, realizam verdadeira emulação, disputando as melhores apresentações artísticas e culturais.

${ }^{140}$ Espaço educacional, onde crianças, jovens e adultos podem ser alfabetizadas e estudar os conteúdos componentes do currículo escolar nacional, além de outros, específicos da realidade dos Movimentos sociais e que na maioria das vezes não são ensinados nas escolas convencionais. A Ciranda também pode funcionar como creche onde os pais deixam seus filhos para poderem trabalhar e participar dos atos fora do acampamento. 
dividi-lo com amigos, formando assim uma espécie de república. As pessoas que vivem nesses acampamentos “dividem-se” entre as atividades de ordem privada, como o trabalho fora (no caso dos que possuem emprego), o cuidado dos filhos e do barraco, o preparo de alimentos; e as atividades coletivas, como organização de atos, participação nas assembléias e realização das atividades específicas do coletivo do qual fazem parte.

O Movimento dos Trabalhadores Sem-teto, ao evidenciar as contradições sociais existentes nas cidades brasileiras, resultantes de um processo de modernização excludente voltado aos interesses capitalistas, passou a lutar por acesso à cidade, no que tange à participação em sua gestão pública e direito de usufruir seus bens e serviços, ou seja, a lutar por um reforma urbana. De acordo com Silva ${ }^{141}$ a persistente busca por uma cidade mais justa e democrática ecoa na discussão em torno da Reforma Urbana, amalgamada por segmentos sociais antagônicos, portadores de compreensão e discursos diferentes sobre a cidade enquanto espaço social complexo. Nesse quadro, a Lei 10.257 de 10 de Julho de 2001, mais conhecida como Estatuto da Cidade é uma iniciativa derivada de pressões da sociedade civil e Congresso Nacional em estabelecer diretrizes federais para a política urbana. De modo sintético, esta Lei estabelece diretrizes gerais para a política urbana, regulamentando o capítulo de política urbana da Carta Magna e estabelecendo instrumentos para a gestão municipal das cidades.

Questão central para a reforma urbana, bem como para a reforma agrária, é a propriedade. Com relação a ela o Estatuto da Cidade estabeleceu importantes instrumentos legais, como IPTU progressivo no tempo às propriedades ociosas, edificação compulsória, desapropriação, discriminação das terras públicas, regularização de loteamentos ilegais e favelas e assegurou uma maior participação popular por meio de emendas que podem ser apresentadas pelos cidadãos às Assembléias legislativas e Conselhos municipais para a definição e/ou reformulação dos Planos Diretores. O advento da participação popular, conforme os preceitos das conquistas sociais do final do século passado e do início deste, enfatiza os princípios como o direito à cidade, gestão democrática da mesma e função social da propriedade ${ }^{142}$.

A aprovação do Estatuto da Cidade foi uma conquista importante de vários setores da sociedade, especialmente dos Movimentos Sociais, mas cabe lembrar que este é apenas um passo para a resolução dos problemas urbanos. Não basta sua existência enquanto mecanismo jurídico. É preciso que vigore de fato, e para isso a participação da sociedade civil continua imprescindível.

Como não só de política vivem as sociedades, e a alimentação é tema recorrente nas narrativas das famílias entrevistadas, passamos agora a discorrer sobre esse assunto.

\footnotetext{
141 SILVA, José Borzacchiello. O ESTATUTO DA CIDADE E A REFORMA URBANA NO BRASIL. In: GEOUSP Espaço e Tempo, 2001, $\mathrm{n}^{\circ} 10$.

${ }^{142}$ SILVA, op.cit.
} 


\section{Alimentação}

Por meio de narrativas nossos colaboradores expressam também suas preferências e habilidades culinárias, concepções dietéticas, aversões, costumes e ritos. Isso porque o alimentarse não é apenas um ato de manutenção do corpo biológico, mas também, do corpo social. Pesquisadores e historiadores da alimentação apontam para a Comensalidade como prática instituinte de nossa humanidade. A preparação de nossos alimentos e seu consumo cerimonial constitui um dos elementos que nos diferencia dos outros animais. De acordo com Flandrin, “acredita-se, geralmente, que o comportamento alimentar do homem distingue-se do dos animais não apenas pela cozinha - ligada em maior ou menor grau, a uma dietética e a prescrições religiosas - mas, também, pela comensalidade e pela função social das refeições” 143

Quando nos referimos ao consumo cerimonial dos alimentos, não estamos falando, necessariamente dos grandes banquetes servidos por reis em seus castelos, para selar acordos ou comemorar vitórias bélicas, nem especificamente de nossas ceias natalinas - com certeza estes são momentos cerimoniais importantes de nossa história e carregados de simbologia - mas estamos nos reportando, principalmente, aos ritos das refeições cotidianas, do comer e beber juntos, da partilha dos alimentos, do passar o prato para que o outro se sirva, do servir primeiro o copo dos comensais, fazer "as honras da casa”. Estes ritos indicam que somos seres de cultura e fortalecem os laços de amizade entre os que se sentam à mesma mesa. De acordo com Leonardo Boff, “é pelos ritos que revelamos nossa humanidade e o grau de civilização que conseguimos alcançar” 144 .

Se vasta parcela da população mundial está excluída da mesa da fartura, e mesmo da mesa dos víveres mais elementares à sobrevivência, subnutrida ou faminta, sofrendo com a má gestão dos recursos hídricos e a insegurança alimentar, é preciso questionar os "rumos da civilização”, o uso que tem sido feito de nossos instrumentos técnicos - já que existem técnicas de produção de alimentos capazes de produzi-los em escala maior que a do crescimento da população - as formas como estes alimentos tem sido distribuídos e o por que de não alimentarem a todos. A fome e a carestia não são resultantes de problemas técnicos, de quantidade insuficiente de alimentos produzidos, mas de um problema ético e político. De uma cultura que se esquece cada vez mais da solidariedade e do cuidado, ainda que mínimo, com o próximo e com o planeta, e de um poder político submisso a interesses econômicos nos quais os ganhos não são democratizados, mas se concentram privativamente nas mãos de uma minoria.

\footnotetext{
143 FLANDRIN, Jean-Louis, MONTANARI, Massimo. HISTÓRIA DA ALIMENTAÇÃO. São Paulo: Ed. Estação Liberdade, 1998, p. 32.

${ }^{144}$ BOFF, Leonardo. VIRTUDES PARA UM OUTRO MUNDO POSSÍVEL. V. III, Petrópolis: Ed. Vozes, 2006.
} 
A alimentação, por ser uma dimensão importante da vida dos indivíduos, em particular, e da sociedade, em geral, merece reflexões mais sistemáticas e maiores atenções do poder público. Ela é reveladora de culturas e de especificidades étnicas, de crenças, visões de mundo e possibilidades materiais de cada povo.

Come-se aquilo que é produzido no solo de cada região e de cada país e aquilo que é possível importar dos demais, come-se o que foi plantado para o próprio consumo e come-se o que sobrou da mesa dos outros. Come-se diferente em cada lugar porque diferentes são as práticas culinárias, diferentes os ingredientes e possibilidades de misturá-los, porque os sentidos são construídos socialmente e finalmente, come-se com os sentidos (visão, tato, olfato, paladar). Come-se diferente no campo e na cidade, a despeito da McDonaldização ${ }^{145}$ do mundo e das preocupações com a funcionalidade, o peso e o prazer. Diferentes são as maneiras de se consumir os alimentos no norte, no sul, no nordeste, sudeste e centro-oeste, e ao que parece, existe uma disputa entre suas cozinhas para ver quem é a melhor. Não entraremos aqui nesse tipo de discussão, porque "gosto não se discute”, ou pelo menos, não deveria ser discutido nesses termos de "melhor ou pior”, “original ou fake”, especialmente no que diz respeito ao Brasil, país híbrido, constituído por muitas culturas e temperos.

As questões que orientam a presente reflexão se modulam da seguinte forma: o que se come? Como? Por quê? Estas três perguntas, em alguma medida, encontram respostas nas histórias de vida das famílias que colaboraram com a presente pesquisa, como veremos a seguir:

\section{Sabores do Campo}

Os sabores do campo aparecem nas narrativas como recordações de um outro tempo e de um outro espaço, no qual se vivia a fartura, ainda que sazonal. Essas narrativas, ao se remeterem a um modo de vida rural, demonstram a falta que seus narradores sentem daquele espaço, idealizado e idílico graças ao trabalho da memória e seus apetites. Esses alimentos desejados, ou esses desejos alimentados, tal como a torta de amoras da fábula "o rei e a omelete de amoras" não se limitam à sua materialidade, pois se assim fosse, poderiam ser substituídos por outros de igual composição e modo de preparo.

A fábula fala de um rei que quando menino, perdido na selva com seu velho pai depois de terem seu reino invadido por inimigos, encontraram uma choupana onde vivia uma velha que lhes preparou uma omelete de amoras, a mais saborosa que o pequeno príncipe em fuga poderia ter experimentado naquela hora difícil, e ao longo de toda a sua vida. Passado os anos, depois de adulto e estabelecido no trono, o jovem rei vivia infeliz e nada o apetecia. Tudo o que ele

\footnotetext{
${ }^{145}$ FISCHLER, Claude. A McDonaldização do mundo. In: FLANDRIN, Jean-Louis, MONTANARI, Massimo. HISTÓRIA DA ALIMENTAÇÃO. São Paulo: Ed. Estação Liberdade, 1998, p.845.
} 
desejava era “aquela” omelete de amoras feita pela anciã da floresta, até que seu sábio cozinheiro, ameaçado de morte pelo rei, caso não conseguisse fazer a omelete de amoras, dá a ele a resposta mais sábia que um cozinheiro daquela época poderia dar, algo mais ou menos assim: "Não posso fazer a omelete que Sua Alteza deseja, sei os ingredientes todos que a receita leva, sei a ordem dos temperos, sei até como devem ser os movimentos para bater os ingredientes, mas nunca poderei fazer uma omelete como aquelas. O que o senhor deseja não é a omelete, é aquele momento, a aventura, a floresta, a velha, a companhia de seu finado pai”.

A narrativa de Dona Maria da Paixão, nordestina que migrou para São Paulo na década de 1970, fala de sabores inesquecíveis: do milho e da batata-doce assados na brasa, das batatas comidas cruas, do leite puro tirado da cabra ou da vaca, da farinha, da tapioca que "sustentava”, da melancia, do caju, do suco de cajá, do imbu, da ciriguela:

\footnotetext{
A época mais feliz da minha vida foi aquela! Com toda a simplicidade, com as dificuldades, com tudo! A gente tinha prazer em levantar de manhã e ir para a roça. Na época de inverno era melancia, caju, manga, cana, abóbora, milho verde, feijão verde, imbu, cajá. Cajá é uma fruta aqui que o povo não conhece. Dá um suco muito bom! (Maria da Paixão)
}

O que torna os alimentos de lá inesquecíveis, insuperáveis não é apenas o seu sabor e a sua qualidade orgânica, mas a comensalidade, a forma como eram colhidos, preparados e consumidos: era todo um trabalho coletivo, realizado por irmãos que se ajudavam mutuamente, que tinham grande respeito pelos pais - "os mais velhos”, que no final do dia partilhavam com os filhos não só os alimentos, mas sua vida, criatividade e imaginação:

\footnotetext{
Quando morava no Piauí era muito bom! A gente buscava lenha no mato, a gente ia para a roça trabalhar, trabalhava na enxada e quando era uma base de umas cinco horas da tarde, cinco e pouco, meu pai falava: “Meus filhos, vão buscar lenha!” Aí a gente ia paro o mato cortar lenha[...]Trazia aquelas lenhas bonitas, colocava no terreiro. Terreiro aqui é coisa de macumba, mas lá, terreiro é a frente da casa, onde nós varríamos com aquelas vassouras de malva que eram uma bênção... Quando era noite o meu pai acendia aquela fogueira e se era época de inverno a gente ia assar milho, assar batata doce, se não era época de inverno o meu pai sentava ali com nós todos e começava a contar história. Mas era mentiroso, contava cada história! Eram lindas as histórias do meu pai! (Maria da Paixão)
}

Alimentos de mesmo nome podem ser encontrados na cidade onde Maria da Paixão e seus filhos residem no momento, ou em qualquer outra cidade do Brasil, mas nunca serão os mesmos e nunca terão o mesmo sabor dos que eram produzidos familiarmente no Piauí de sua infância. O 
que essa família deseja, tanto quanto aqueles frutos propriamente ditos, é a convivência fraterna, a atmosfera de respeito, paz e alegria que favorece as relações familiares e sociais, e estreita os vínculos que possuem entre si.

Não é diferente o que expressa as histórias de vida da família de Carla, na capital do Estado de Rondônia. Inclusive, muitos dos alimentos consumidos por aquela família são os mesmos degustados pela família de Maria da Paixão, quando esteve no nordeste:

\footnotetext{
“[...] aqui em Porto Velho a gente comia coisas da região... Mingau de milho, que lá para o Sul chamam de canjica, aqui chamamos de "mingau de milho" ou "mugunzá". Comíamos macaxeira, milho assado na fogueira, banana assada na fogueira, batata doce, esse tipo de coisas”. (Carla)
}

Semelhante também era o clima em que esses alimentos eram saboreados: clima de confraternização e partilha:

Lembro de coisas que a gente não vê mais, como festas juninas, reuniões de família...

No meu tempo de menina as famílias se reuniam, chamavam os vizinhos e em época de festa junina faziam fogueira, contribuíam uns com os outros para fazer a festa.. (Carla)

Com o passar dos anos e a vida estabelecida na cidade, os sabores do campo, ou pelo menos, os sabores “daqueles campos” continuam presentes somente nas recordações e nos desejos dos que o provaram um dia. Novos hábitos alimentares são estabelecidos.

\section{Sabores da Cidade}

Sem excessivo romantismo, é preciso reconhecer que a vida no campo é favorável a uma relação mais próxima com os alimentos. Você os planta, acompanha o crescimento, colhe, prepara, e se não participa do processo como um todo, pelo menos está presente em uma parte maior dele. Na cidade, devido ao ritmo de vida instaurado a partir da Modernidade, a relação com os alimentos tem se tornado instantaneamente mais distante. Muitas vezes não somos nós que o compramos - terceirizamos também essa atividade -, e também não somos nós que os preparamos, já que cada vez mais fazemos nossas refeições em restaurantes e lanchonetes. Acontece até de comermos por “obrigação”, sem sentir nenhum prazer e sem sequer reconhecer o que estamos levando aos lábios. Talvez isso se dê por estarmos desatentos, preocupados com outras coisas, insensíveis a essa importante dimensão de nossa existência e/ou também porque esses alimentos são de qualidade questionável e mal preparados. É freqüente em restaurantes universitários os 
estudantes brincarem sobre o sabor dos sucos servidos: "Que teremos hoje? Suco de vermelho, suco de amarelo ou suco de laranjado?” já que o que se destaca é apenas a cor, identificação do sabor depende de um esforço imaginativo.

No campo se comem preferencialmente os “frutos da terra”, produtos não industrializados: milho, macaxeira e seus derivados, e as frutas características de cada região ou adaptadas artificialmente a seu solo; na cidade, o discurso dominante prioriza alimentos "funcionais" e de baixo teor calórico, embora existam diversas práticas alimentares, o que nos leva a pensar na multiplicidade de sabores que nela existem. De pratos congelados, sanduíches das grandes franquias multinacionais às generosas porções dos almoços de domingo, há escalas relativas de sabor. No mesmo espaço convivem os que têm a possibilidade de almoçar em casa e cozer seus próprios alimentos, os que se satisfazem com hambúrguer e batatas fritas, os que comem de tudo, adaptando-se às circunstâncias, e os que recusam qualquer tipo de alimento.

Diante das incertezas frente ao que se come, dos problemas de segurança alimentar, da carestia e da fome, uma coisa é certa, mudamos nossa maneira de nos alimentar. Não só boa parte dos alimentos que ingerimos foi modificada, seja no transporte, na aplicação dos temperos e conservantes, na conservação depois de cozidos ou mesmo em seus genes, como também se alterou nosso comportamento alimentar, nosso modo de nos portarmos à mesa - e é sobretudo isso que deve ser levado em consideração. O mais importante não é o que se põe à mesa, o que se consome nas refeições, mas o como se consome, o que não quer dizer que não devamos nos preocupar com a qualidade dos alimentos e seus processos produtivos e distributivos. Atualmente percebe-se nas cidades um retraimento da prática da partilha, quase já não se faz as refeições com a família e com os amigos, e muito menos com os desconhecidos que eventualmente podem solicitar nossa hospitalidade.

Quando não se partilha os alimentos, quando não se pratica a comensalidade, não são apenas os alimentos que deixam de circular entre o grupo, mas as experiências e as histórias. Nesse processo, até os símbolos são modificados, adquirem novas conotações. Um exemplo disso é a mesa e os próprios alimentos, pois estes são mais do que coisas materiais, são símbolos do encontro e da comunhão ${ }^{146}$. A mesa continua sendo local de encontro entre as pessoas, mas em vez de trocas de experiências, ao seu redor cambiam-se informações, fazem-se negócios. Ela já não é mais o ponto de convergência diário das famílias, diante do qual se reflete sobre as situações vividas no dia-a-dia, manifesta-se as alegrias e decepções, coloca-se em “pratos limpos” as atitudes questionadas pelo grupo e anunciam-se as grandes mudanças. Ana Terra comenta que:

${ }^{146}$ BOFF, op.cit. 
Em geral, nas casas, o lugar e o momento de congregação das pessoas é a mesa, na hora de comer. Lá em casa nunca foi assim, primeiro porque a gente nunca jantou, nunca teve o hábito de jantar. A gente almoçava, eu e o Igor ficávamos soltos pelo condomínio, brincando, e de tarde, de tardezinha, comíamos um sanduíche. Comíamos bastante no café e na hora do almoço: cada um chegava, fazia seu prato e saia andando, não tinha união na hora do almoço...

Para muitos, a mesa atualmente é apenas um móvel e já não é utilizada para congregar pessoas. Da mesma forma, os alimentos continuam sendo "alimentos", no sentido de nutrirem o organismo, mas a maneira como são tomados: individualmente, com pressa, muitas vezes em meio a outras atividades, não propicia mais a alegria do encontro, a intimidade, a franqueza e o sentimento de pertença a um grupo, a uma cultura e uma tradição culinária.

O modo de vida que vigora nas cidades ocidentais é marcado por certa insensibilidade frente aos sabores do convívio íntimo com o outro. Convive-se relativamente bem, superficialmente bem porque as diferenças não são "postas à mesa” e não se realiza de fato um enfrentamento do outro e de si. Nesse modo de vida impera uma ética da apatia, despreocupada e descuidada com o mundo, que ora sofre de surtos de nostalgia, ora tem lampejos de consciência da situação crítica em que se encontra. Podemos citar como exemplo do primeiro caso, discursos que revelam apego a um passado idealizado, de vida "simples no campo", de fartura e convivência harmônica, no qual as relações pessoais são privilegiadas em relação à lógica do ter. Para ilustrar os insight de consciência do segundo caso e as dúvidas que o modo de vida de que temos tratado instaura, destacamos um trecho da narrativa de Carla:

O Natal hoje em dia está mais sofisticado, com comidas de luxo, coisas que a gente não vê na mesa das pessoas humildes. Aí é quando esse tipo de festa perde a essência, perde o significado, porque se vê tanta coisa na mesa de quem tem poder, e na mesa de quem não o tem muitas vezes não há sequer o que comer. Conheço casos de amigas minhas que na época do Natal não tinham o que comer, enquanto na casa ao lado estava tento festa, muita comida e bebida [...] perdeu-se a essência quando você esqueceu que seu amigo do lado não tem o que comer. Você está festejando o Natal hoje, comendo, bebendo, mas está esquecendo que do teu lado tem alguém que não tem nem o que comer. E que adianta comemorar desta forma? Será que se tira proveito disso?

Mas como Carla mesmo diz no conjunto de seu texto, não são apenas as festas natalinas que passaram a ser celebradas de um modo "sem sentido” e cego às fomes do próximo. As quermesses, as refeições diárias e as festas juninas também são reconstruídas sob outra lógica, a do consumo, da competição, da mercantilização:

Antigamente as famílias se reuniam, sentavam, conversavam. Não tinha televisão. Hoje, devido ao desenvolvimento as coisas ficaram bem diferentes... Lembro de coisas que a gente não vê mais, 
como festas juninas, reuniões de família [...] Hoje, se você quer participar de uma festa junina tem que ir aos arraiais de comunidades religiosas, empresas, instituições, mas nesses arraiais há competição e aglomeração de estranhos, não existe mais aquela coisa familiar. O mesmo ocorre com as festas de final de ano, as festas natalinas. Antigamente toda a família se reunia, comemorava-se em família, hoje não, pois chega essa época e as pessoas se preparam para ir aos clubes, se esquecem da confraternização e do que significa aquilo.

As narrativas das duas famílias entrevistadas apontam para diversos pontos em comum, talvez pela semelhança da experiência que vivenciam com relação à moradia, talvez porque suas progenitores e "chefes", ambas mulheres divorciadas, inteligentes e formadoras de opinião (Carla professora e Maria da Paixão, pregadora) tenham ensinado seus filhos a olhar para o mundo e experimentar as variedades de seus frutos que são acessíveis àquela classe social. Mas nem todos se comportam igual e apreciam as mesmas coisas: Caio prefere se servir de arroz e feijão, mesmo que lhe seja possível escolher entre uma diversidade de outros pratos, porque entende o arroz e o feijão como alimentos capazes de sustentá-lo para o dia de trabalho, Filipe, recusa-se a comer arroz e feijão, não aprecia o sabor daqueles alimentos e talvez os recuse, também, por lhe fazerem recordar os limites impostos aos trabalhadores pobres, limites que ele almeja superar. Luana gosta de uva e de pizza, Laura adora azeitonas verdes, Carolina sabe preparar diversos pratos da culinária amazônica, mas não aprecia farinha, um de seus elementos básicos. Carla atribui à cozinha amazônica alimentos como o vatapá, que naquela região pode ser acompanhado de maionese, arroz e frango assado.

Peixe assado ou guisado, pato no tucupi, galinha à cabidela, tacacá, acarajé, casquinhas de caranguejo, panelada de quelônios, tapioca, cocada, mugunzá, doce de leite, de abóbora, de cajá, de jaca, mingau de banana, broa de milho, beiju são alimentos presentes no cardápio das cidades, especialmente (de um modo todo especial) nas cidades do norte e do nordeste do Brasil, todavia, o que parece constituir mesmo os "sabores da cidade", atualmente, são os biscoitos recheados, os bolos de confeitaria, os sanduíches de frios e a coca-cola. São esses alimentos, raros na infância de Carla e Marcelo, que hoje são apreciados com maior satisfação por crianças e adultos, como podemos observar nas narrativas:

Quando eu era pequeno, comprar um presunto, comprar um queijo e até uma coca-cola era um luxo. Quando tinha isso a gente comia e parece que era uma festa. Hoje o negócio ficou mais fácil, todo mundo pode comer um presunto, tomar uma coca-cola, comer um doce diferente. (Marcelo) 
A gente tinha o costume de comer fruta, mas as outras coisas eram meio difícil, porque tinha que comprar. Então, hoje, adoro chocolate, biscoito, refrigerante, bolo, talvez porque tenham me faltado na infância, e isso fica no subconsciente da gente. Não sei, penso eu que sim. (Carla Regina)

Além de comentar as mudanças na alimentação que vêm presenciando no decorrer da vida, alguns colaboradores apresentaram receitas de pratos que apreciam, seja por seu sabor, por seu valor nutritivo ou mesmo por expressarem concepções dietéticas vinculadas à soberania e a segurança alimentar. A esse respeito, Ana Terra dá a sua receita não só para o café da manhã, mas para uma vida saudável:

\begin{abstract}
Abacate é rango! Você vai comer pão no café da manhã? Pão branco? Coisa mais venenosa que tem: farinha branca, arroz banco, açúcar branco. É tudo branco, tudo refinado, tamanho desperdício de energia e de nutrição que dá aflição até de pensar! [...] A quantidade de plantas medicinais, a quantidade de técnicas simples para as pessoas manterem a saúde é extensa. Tomar um copo de água antes de dormir e depois de acordar, por exemplo, evita muita doença, o cuidado com a alimentação, o cuidado com a hidratação, o extremo cuidado para não ficar consumindo veneno, uma vida que não seja sedentária [...] todas essas coisas garantem muito mais a nossa saúde do que qualquer remédio.
\end{abstract}

Para Ana Terra, a saúde, a alimentação, a subsistência física não são questões simplesmente biológicas. Ela as percebe como instância primordial da existência, que vem se deteriorando com a vida moderna. Ela aponta para uma característica cultural de nosso tempo: o consumo de alimentos industrializados e os temores quanto à “falta de higiene”, que leva as pessoas a preferirem alimentos pasteurizados, transgênicos ou que receberam agrotóxicos em sua produção, visto que parecem mais limpos, bonitos e saudáveis do que os alimentos orgânicos ou que não passaram por longos processos industriais. Essa característica cultural que Ana Terra identifica como uma espécie de "histeria coletiva" ou "transtorno obsessivo compulsivo" é engendrada pelo capitalismo, que em sua concepção, só poderá se superado de dois modos:

Não acredito que seja possível matar o Capitalismo de porrada, não acredito mais. Acho que ele só tem duas formas de morrer: doença, porque já está doente, já tem claros sinais de que é uma sociedade doente e um sistema doente, mas essa possibilidade não me agrada nada, porque significa ele cair e as pessoas caírem junto. Significa grandes crises de recursos, grandes crises financeiras, da Bolsa de 1929 para cima. Coisas muito piores. E outro jeito de matá-lo é por inanição. É esvaziar, sair fora dele, construir uma outra cultura a partir dos interstícios dele próprio [...] o Capitalismo vai ficar quietinho, deixando a gente fazer isso tudo em paz até de repente ele morrer de inanição, mas acho que só é possível derrubá-lo e salvar o ser humano no processo, salvar a vida do planeta no processo se for desse jeito, se for juntando diferentes 
universos de conhecimento, de práticas, de valores que são alternativos a ele, miscigenando-os de diferentes formas, em diferentes lugares, conforme as especificidades do contexto e das pessoas que o estão fazendo acontecer.

Diante das crises contemporâneas na área da segurança alimentar, como as amplamente noticiadas "gripe do frango”, “vaca louca”, "rebanhos bovinos contaminados por febre aftosa” e dos crescentes números tanto de obesos quanto de subnutridos, parece haver uma tendência de busca do "equilíbrio perdido". Esta se dá, sobretudo em um ambiente urbano que idealiza o rural e reinventa um modo de vida campestre, por entendê-lo mais condizente com uma vida saudável. Não se trata de um retorno físico ao campo - a cidade continua sendo o espaço de vida privilegiado pela maior parte da população brasileira - mas de retomada de saberes próprios do mundo rural, que podem ser notados, por exemplo, em uma medicina alternativa - cuja terapêutica é constituída por chás de ervas naturais, infusões, banhos, passeios ao ar livre -, ou na valorização dos alimentos orgânicos, similares aos que foram produzidos durante séculos: sem adubos químicos e sem agrotóxicos.

Na década de 1970, quando escreveu “O campo e a cidade na história e na literatura”, Raymond Williams sugeriu que a imbricação entre campo e cidade, a dialética e o modo de vida que geram acontecesse porque:

[...] a maioria das pessoas, antes de adquirir qualquer educação literária, aprende a conhecer e dar valor à vida tradicional - bem como a sentir as tensões por ela impostas. Vemos e aprendemos com base no modo como nossas famílias vivem e se sustentam; um mundo de trabalho e costumes locais, e de crenças tão profundamente dissolvidas nas ações cotidianas que de início nem sequer sabemos que são de fato crenças, passíveis de mudança e questionamento ${ }^{147}$.

Se não podemos afirmar de modo completo que em nossa sociedade contemporânea a valorização da vida tradicional precede a educação letrada, pois parece ocorrer o inverso: a educação literária fornecer substratos para essa valorização e reinvenção bucólica. Todavia, é inegável o papel da família no legado de uma memória coletiva repleta de representações sociais do campo e da cidade, que orientam condutas e novas leituras da realidade.

Retornamos às perguntas do início dessa reflexão: de que se nutrem os colaboradores desta pesquisa, como e por quê. A resposta à primeira pergunta foi bem respondida por Ana Terra: “Arroz, feijão e coisas”, sendo que “coisas” indicam uma variedade de verduras, legumes, 
massas, molhos e carnes (esta última só para quem não é vegetariano). O “como se come” manifesta-se de dois modos básicos: individualmente e coletivamente, e envolve, ou não, o uso dos diversos sentidos corporais, da memória, dos desejos inconscientes. A terceira pergunta é a mais difícil de ser respondida por que envolve estruturas antropológicas, sistemas de crenças, poder aquisitivo, política de produção e distribuição de alimentos, gostos pessoais, aversões, identidades. Come-se $\mathrm{X}$ e não $\mathrm{Y}$, e de modo $\mathrm{N}$ e não $\mathrm{M}$ porque se gosta de comer assim e porque foi permitido agir de tal modo, porque esse é o modo acessível.

O acesso a essas respostas, a compreensão do comportamento desse grupo frente à alimentação, uma vez mais demonstra-nos a importância da comensalidade. Apesar de todas as dificuldades enfrentadas por aqueles trabalhadores, da adversidade de suas condições materiais, das divergências ideológicas presentes em seus discursos, conseguem se manter coesos na luta, e principalmente, manter a alegria de viver e conviver. Não será a forma como eles comem o segredo para tal vitalidade de espírito? Acreditamos que sim, mas não apenas isso. Há outros “alimentos” que produzidos e consumidos ritualmente, fortalecem o grupo em sua caminhada: aquilo que genericamente é denominado de “mística”. 


\title{
Mística: arte da vida terrena
}

Mística é um termo enfatizado nas narrativas de Ana Terra e Marcos. Na narrativa de Ana Terra ela aparece relacionada, primeiramente, ao Movimento de Biologia, apontando para uma de suas origens:

\footnotetext{
Mística é uma coisa importada do MST, mas que no Movimento de Biologia foi tomando características próprias. No ENEBI ela consiste em uma apresentação, uma enquête, uma música, ou um momento em que as pessoas saem fazendo massagem uma nas outras, enfim, tem uma série de coisas que pode ser considerada Mística.
}

Mas aparece também, na narração de Ana Terra, vinculada ao MTST, particularmente à experiência traumática do despejo sofrido por integrantes da ocupação Chico Mendes, em Taboão da Serra:

\begin{abstract}
Aquele terreno onde tinha sido o nosso Acampamento me lembrou muito as ruínas de Hiroshima, pode até parecer megalomaníaco, mas foi o que me veio na cabeça e lembro que, nossa, parece até coisa de filme... A gente tinha plantado uma árvore uma árvore simbólica, com madeirinhas pregadas e papel crepon verde, em volta, então parecia uma árvore de cenário e nela - isso foi uma mística que a gente fez a gente pregou plaquinhas de madeira que tinham vários escritos: Igualdade, Educação, Amor, Utopia, várias coisas, e quando cheguei lá, algumas dessas plaquinhas estavam pelo chão, parcialmente preservadas. Aí não agüentei, desabei, chorei como uma criança. Retirei-as do chão e guardo-as comigo”. (Ana Terra).
\end{abstract}

Esse trecho da história de vida de Ana Terra remete-nos a três temporalidades em que a mística da “árvore com plaquinhas” esteve presente: a primeira, na própria ocupação Chico Mendes, onde se “plantou” simbolicamente uma árvore e pendurou em seus galhos os frutos que gostariam de colher: igualdade, educação, amor; a segunda, logo após o despejo e a destruição do acampamento pelo fogo, pela violência, pelo poder dos que “detêm o poder”: é quando Ana Terra recolhe os “cacos” do que sobrou e leva-os consigo, não para a casa, que nesse momento mostra-se ainda mais longe de ser alcançada, mas pelo caminho incerto, reservado aos errantes filhos de Adão que almejaram o "fruto proibido". A terceira temporalidade é instaurada pela narrativa, que a partir da vivência ritualizada do fim da ocupação permite à narradora interpretar positivamente aquela experiência, ou melhor, extrair dela ânimo para seguir adiante, junto com os seus, rumo à "terra prometida”: 
Queria passar por aquilo, sabe? Sei lá, dizer tchau, me expor àquela dor muito ruim de ver o poder de destruição que quem tem Poder possui [...] Acho que foi importante eu passar por essa coisa tão violenta de sentir que aquilo foi destruído. Se por um lado, para mim, o carinho que tenho pelas pessoas é combustível para querer mudar o mundo, preciso também aprender a transformar em combustível esses sofrimentos, esses grandes incômodos. Quero ter esses dois tipos de combustível: o carinho e o incômodo e olha, a lembrança de passar pelo Chico Mendes e encontrar aquelas plaquinhas no chão me acompanha e é combustível. Uma coisa muito forte!

A “árvore” cortada e queimada é signo dos Movimentos Sociais que brotam em nosso solo, com suas diferentes siglas, bandeiras e concepções ideológicas. Movimentos que são rechaçados dia-a-dia, que enfrentam a desmobilização provocada pelas medidas paliativas do Governo (a "bolsa aluguel” para alguns, em vez de reforma urbana, a desapropriação de umas poucas fazendas ocupadas por agricultores sem-terra, em vez de reforma agrária), a criminalização por parte da imprensa, da sociedade e da polícia (também uma forma de desmobilização), e o descaso político, causador de sentimentos como vergonha, humilhação, incompetência pessoal, infelicidade que atinge de modo peculiar às classes pobres. Não é à toa que “Chico Mendes” é o nome que batiza tantas ocupações e brigadas de trabalhadores sem-teto e sem-terra de norte a sul desse país. Mártir do povo pobre, seu estandarte se impõe contra os lenhadores e ceifadores da vida humana. Sua mensagem foi entendida pelos explorados da floresta e da cidade e motiva-os na semeadura e colheita dos frutos da justiça social. Chico Mendes é um ícone presente no imaginário das duas ocupações e a postura que teve em vida é incentivo para a luta dos trabalhadores dessas ocupações.

Bárbara conta em seu texto sobre a visão das “correntes no chão”, de como esteve perto a libertação de seus amigos, mas que uma nova ordem de despejo veio atrapalhar. Fala sobre como as algemas da injustiça sufocam a vida que poderia ser livre e segura, com as mães junto de seus filhos $^{148}$. Ana Terra fala das placas caídas no chão, placas que eram os frutos da árvore simbólica, e é porque os frutos reais que aqueles representam ainda não foram colhidos que inúmeras famílias, vinculadas ou não a Movimentos Sociais seguem em sua luta diária.

Nos dois casos acima mencionados percebemos a presença de um elemento em comum: o solo, o chão. É sobre ele que ficam as correntes, os frutos, as pessoas. É sobre a terra que a mística é exercitada e é sobre ela que se espera ver os “milagres” desejados.

Na tradição escolástica cristã, a mística foi entendida como um encontro com Deus (também chamado de o Outro), caracterizado pela crença ou sentimento de transcendência experimentado pelos homens ou mulheres de vida ascética. Os exemplos mais conhecidos de

\footnotetext{
${ }^{148}$ Ver narrativa da Bárbara.
} 
pessoas que viveram esse encontro com o Outro misterioso são Santa Teresa de Ávila e seu discípulo São João da Cruz. Mais próxima de nós, a Teologia da Libertação, desenvolvida na América Latina a partir dos anos 1970, nos oferece a seguinte conceituação de Mística: “[...] o conjunto das convicções profundas, as visões grandiosas e as paixões fortes que mobilizam pessoas e movimentos na vontade de mudança, inspiram práticas capazes de afrontar quaisquer dificuldades ou sustentam a esperança face aos fracassos históricos”149 . É por esse prisma que buscamos compreende-la nesta pesquisa.

A mística é o que move as pessoas. Ela catalisa as esperanças, os sonhos, as crenças, as revoltas e os desejos de transcendência. No caso dos Movimentos Sociais que conhecemos por meio das histórias de vida de nossos colaboradores, trata-se de um desejo de transcendência não desta terra para o reino dos céus, mas da transcendência de dadas condições materiais e sociais para outras em que se possa viver feliz. Ao que parece, estamos diante de uma mística sem Deus ou seres sobrenaturais - o que não quer dizer que não exista, nesses Movimentos, pessoas que creiam nessas entidades - estamos diante de uma mística que atribui a “outras coisas” o sentido do sagrado: como à vida, à partilha, à equidade social. Sua motivação encontra-se em outras crenças, como a História ou a possibilidade de Revolução, por exemplo.

Sebastião Vargas Netto, ao comparar movimentos sociais como o MST, no Brasil e o $\mathrm{EZLN}^{150}$, no México, apontou a existência de uma mística rebelde que perpassa a ambos, bem como a existência de

[...] diversos movimentos ateus, artísticos como o surrealismo ou políticos, como alguns comunismos, que evidentemente possuíam sua mística própria: a História, ou no caso do Surrealismo, o Inconsciente - e não mais o sobrenatural constituiria fonte de inspiração e fé místicas. A ideologia substituiria a especulação e a profecia, e a práxis revolucionária se tornaria verdadeira ascese”. 151

No MTST a mística se expressa por meio de variadas atividades culturais, que contam como matéria-prima a expressão corporal e a criatividade no uso dos materiais disponíveis. Dentre essas atividades destacam-se danças, encenações, cantigas de roda, contação de histórias e confecção de artefatos como faixas e bandeiras. Frequentemente esses momentos são vividos com emoção e profundo respeito e as pessoas que o vivenciam retiram dele alguma "lição de vida”, sem falar no fortalecimento da união entre os membros do grupo e da identidade de militante.

\footnotetext{
${ }^{149}$ BETTO, Frei, BOFF, Leonardo. MÍSTICA E ESPIRITUALIDADE. Rio de Janeiro: Garamond, 2005, p. 49.

${ }^{150}$ Exército Zapatista de Libertação Nacional.

${ }^{151}$ VARGAS NETTO, Sebastião Leal Ferreira. A MÍSTICA DA RESISTÊNCIA. São Paulo: FFLCH/USP Tese de Doutorado, 2007, p. 265.
} 
Para Ana Terra, a mística é um embelezar as coisas, "tornar mais encantado” aquilo que já possui seu encanto ou que o teve abalado por algum motivo. Para Marcos, é um mergulho em si mesmo, indispensável para o auto-conhecimento e a melhoria do convívio social:

Conheço uma brincadeira, uma mística que ajuda muito na autocrítica. Você pega uma caixinha, coloca um espelho dentro e coloca também papeizinhos com os nomes das pessoas presentes. Aí cada pessoa vai tirar um papelzinho e falar a principal qualidade e o principal defeito da pessoa cujo nome está escrito nele, mas se esquece do espelho que está dentro da caixa e reflete sua própria imagem! Todo mundo acha que está falando sobre o outro, mas não! Na verdade, está falando de si próprio, de seus defeitos e qualidades, está se olhando no espelho. É importante saber se olhar no espelho, reconhecer a própria imagem, os erros e as virtudes, é preciso ver as virtudes também, ver a beleza, não podemos ficar nos menosprezando, assim como não podemos ficar projetando nossos defeitos nos outros, criticando os outros. É preciso se enxergar! Como vou te criticar se também estou errado? Agora se não tiver um espelho para me olhar, vou te criticar a vida inteira e achar que estou sempre certo! (Marcos).

Na metáfora do espelho encontramos o significado da mística: o encontro com o Outro desconhecido, que é a outra face do próprio ser. Talvez nessa disposição de encontro e reencontro esteja a possibilidade de uma vida mais dedicada ao cuidado de si e mais preocupada com o bem-estar do próximo, uma vida de convivência menos conflituosa, já que as diferenças são relativizadas.

O Movimento dos Trabalhadores Sem-teto de Rondônia e o MTST são tributários da mística do MST, das CEBs, do Anarquismo e de outros projetos transcendentais, mas recriam e atribuem novos valores e significados aos tesouros dessa herança, assim como conserva alguns. E utilizando a metáfora do “combustível”, apresentada por Ana Terra, entendemos que a mística é combustível que leva adiante o bonde da história - que continua sendo, além das outras lutas, a luta das classes. 


\section{Considerações Finais}

Sem ter tido a pretensão de esgotar o tema a que nos propusemos a investigar, porém com a esperança de ter conseguido pelo menos abordar algumas questões pertinentes, e ao mesmo tempo, suscitar outras, nessa tão complexa e ampla problemática, que é a de famílias em busca de um lugar na cidade e de respeito aos direitos humanos, especialmente o direito à vida acima do direito à propriedade, chegamos às “considerações finais” deste trabalho. Apenas considerações porque não podemos, como afirmou Ataíde, “construir conclusões sobre temas ou dramas que no auge de sua vitalidade assomam à nossa realidade e permanecem nela de forma flagrante e intensa” 152 .

Esperamos que nosso esforço em construir um registro das experiências de vida narradas por essas famílias e interpretar problemas suscitados por elas, sejam um "levantar as cortinas” para que outras reflexões sobre essa problemática sejam desenvolvidas.

Procuramos compreender como duas famílias de diferentes regiões do Brasil percebem as cidades onde vivem, organizam suas relações e expressam suas lutas por moradia. Entendemos que as relações familiares, as casas nas quais encontraram abrigo ou nas quais desejam habitar, assim como suas cidades vividas/sonhadas têm a nuança da experiência de ter sido "atirado ao mundo”, “posto fora de casa”, vivido em circunstâncias adversas. Os espaços apresentados não têm os limites exatos dos que existem com os mesmos nomes: a São Paulo de Luana, a Porto Velho de Camila ou a Rio Branco do Caio, tiveram, em uma dialética interminável, suas dimensões sensibilizadas, o que se explica pelo fato de que quando evocamos lembranças dos lugares onde vivemos, adicionamos a elas valores da imaginação.

As narrativas expressam os limites virtuais dos espaços habitados, dos espaços passíveis de habitação, das relações entre pais e filhos, das identidades, dos projetos familiares e políticos. Expressam esperanças, lutas, ressentimentos, situações de encontro, desencontro, frustração, paixões e o desejo de voltar para casa ou construir uma nova. A casa, como sabemos, é um corpo de imagens que dão ao homem razões ou ilusões de estabilidade e o teto revela de pronto sua razão de ser: cobrir o homem que teme a chuva e a tempestade ${ }^{153}$. Diante das inseguranças de tempo de crise, no qual paradigmas são contestados, ideologias caem como muros ou torres, o desemprego é um problema estrutural e as condições de vida do trabalhador se degradam a cada dia, nada mais justo que a luta dessas famílias por justiça social.

O que elas buscam possui conotação material, mas não se limita a isso. Almejam sim, uma casa para morar, abrigar seus descendentes e seus objetos biográficos, um trabalho que lhes

\footnotetext{
${ }^{152}$ ATAÍDE, op. cit., p. 271.

${ }^{153}$ BACHELARD, Gaston. A POÉTICA DO ESPAÇO. São Paulo: Martins Fontes, 2003.
} 
permita prover o sustento, uma infra-estrutura capaz de tornar a vida mais tranqüila, mas desejam também os valores simbólicos disso tudo, as sensações, a intimidade, o segredo, o respeito e por isso, o que tentamos comunicar com esta dissertação, nunca poderia ser dito de modo totalmente objetivo. Seguimos as pistas das narrativas dos colaboradores, deixamos as nossas próprias, no intuito de orientar para outros caminhos.

Encontramo-nos, a essa altura, cientes das limitações deste estudo e abertos às críticas, mas satisfeitos porque alcançamos nosso principal objetivo: constituir um registro que captasse aspectos da experiência de nossos colaboradores, pessoas que nunca antes haviam "dado o seu testemunho”, falado sobre si, suas aspirações e a vida que levam. Este trabalho tornou possível esse registro, ainda que modesto; favoreceu a explanação de alguns pontos significativos do discurso daquele grupo e é um convite não só para a reflexão sobre questões de nosso tempo, mas para a ação transformadora da sociedade. 


\section{BIBLIOGRAFIA}

ACOSTA, Ana Rojas; VITALE, Maria Amália Faller (orgs). FAMÍLIA: REDES, LAÇOS E POLÍTICAS PÚBLICAS. São Paulo: CortezไIE\PUC-SP, 2005.

AGAMBEM, Giorgio. O PODER SOBERANO E A VIDA NUA: HOMO SACER. Belo Horizonte: Ed. UFMG, 2004.

ALMEIDA, Ângela Mendes de. FAMÍLIA E HISTÓRIA: QUESTÕES METODOLÓGICAS. (URL: http://www.usp.br/nemge/textos_seminario_familia/), consultado em 02 de Dezembro de 2007.

ALBERTI, Verena. HISTÓRIA ORAL: A EXPERIÊNCIA DO CPDOC. Rio de Janeiro: Ed. UFRJ, 1992.

ANDERSON, Michael. ELEMENTOS PARA A HISTÓRIA DA FAMÍLIA OCIDENTAL. Lisboa: Querco, 1984.

ARANTES, Antonio. A GUERRA DOS LUGARES. In: Revista do Patrimônio Histórico e Artístico Nacional, n.23, Cidade. São Paulo: IPHAN, pp.191-203.

ARAÚJO, Daniel Guimarães de. POBREZA E DESIGUALDADE: UMA ABORDAGEM SOB A PERSPECTIVA DA MORALIDADE POLÍTICA. São Paulo: FFLCH/USP, 2004 (Dissertação de Mestrado).

ARENDT, Hannah. ENTRE O PASSADO E O FUTURO. São Paulo: Ed. Perspectiva, 2005.

ARIES, Philipe. HISTÓRIA SOCIAL DA CRIANÇA E DA FAMÍLIA. Rio de Janeiro: Ed. Zahar, 1981.

ARRUDA, Gilmar. CIDADES E SERTÕES. Bauru: EDUSC, 2000.

ATAIDE, Yara Dulce Bandeira. CLAMOR DO PRESENTE. São Paulo: Ed. Loyola, 2002.

BACHELARD, Gaston. A POÉTICA DO ESPAÇO. São Paulo: Martins Fontes, 1993.

BARBOSA, Xênia de Castro Barbosa. PERFORMANCE E OBJETO BIOGRÁFICO: QUESTÕES

PARA A HISTÓRIA ORAL DE VIDA. São Paulo: Rev. Oralidades: nº. 02, FFCH, 2007.

VOZES DO SILÊNCIO: HISTÓRIA ORAL COM DOENTES MENTAIS. (URL:

http://www.unir.br/ albertolinscaldas/vozesdosilencio.htm ).

BARBOSA, Jorge Luis. A CIDADE CAÓTICA: IDEOLOGIA E SIMULAÇÃO DA CRISE A SOCIEDADE URBANA. In: GEOUSP Espaço e Tempo, 2001, $\mathrm{n}^{\circ} 10$.

BARBOSA, Fabíola Holanda. EXPERIÊNCIA E MEMÓRIA: A PALAVRA CANTADA E A PALAVRA CONTADA DE UM NORDESTINO NA AMAZÔNIA. São Paulo: FFLCH/USP, 2006. (Tese de Doutorado).

BARTHES, Roland. CRÍTICA E VERDADE. São Paulo: Perspectiva, 2001.

BAUMAN, Zigmunt. IDENTIDADE. Rio de Janeiro: Jorge Zahar Editor, 2005.

, COMUNIDADE. Rio de Janeiro: Jorge Zahar Editor, 2005.

, VIDAS DISPERDIÇADAS. Rio de Janeiro: Jorge Zahar Editor, 2005.

, EM BUSCA DA POLÍTICA. Rio de Janeiro: Jorge Zaha Ed., 2000. 
BETTO, Frei, BOFF, Leonardo. MÍSTICA E ESPIRITUALIDADE. Rio de Janeiro: Ed. Garamond, 2005.

BENÉVOLO, Leonardo, HISTÓRIA DA CIDADE. São Paulo: Perspectiva, 2001.

BENJAMIN, Walter. O NARRADOR. MAGIA E TÉCNICA, ARTE E POLÍTICA. São Paulo: Ed. Brasiliense, vol. 01, 1987, pp. 197-221 (Obras Escolhidas).

BERMAN, Marshall. TUDO QUE É SÓLIDO DESMANCHA NO AR. São Paulo: Ed. Companhia das Letras, 1986.

BLAY, Eva Alterman (org.). A LUTA PELO ESPAÇO. Petrópolis: Ed. Vozes, 1979.

BLOCH, Marc. APOLOGIA DA HISTÓRIA OU O OFÍCIO DO HISTORIADOR. Rio de Janeiro: Jorge Zahar Editor, 2001.

BOFF, Leonardo. VIRTUDES PARA UM OUTRO MUNDO POSSÍVEL. Petrópolis: Ed. Vozes, v. III, 2006.

BOOKCHIN, Murray. O BAIRRO, A COMUNA, A CIDADE: ESPAÇOS LIBERTÁRIOS. São Paulo: Ed. Imaginário, 2003.

BOSI, Ecléa. O TEMPO VIVO DA MEMÓRIA: ENSAIOS DE PSICOLOGIA SOCIAL. São Paulo: Atelier Editorial, 2003.

MEMÓRIA E SOCIEDADE: LEMBRANÇAS DE VELHOS. São Paulo: Ed.Companhia das Letras, 1994.

BRAUDEL. Fernand. A LONGA DURAÇÃO. In: História e Ciências Sociais. Lisboa: Ed. Presença, 1986.

BRUNER, Jerome; WEISSER, Susan. A INVENÇÃO DO SER: A AUTOBIOGRAFIA E SUAS FORMAS. In OLSON, David R.; TORRANCE, Nancy. Cultura Escrita e Oralidade/141,161, São Paulo: Ed. Ática, 1995.

CALDAS, Alberto Lins. NAS ÁGUAS DO TEXTO: PALAVRA, EXPERIÊNCIA E LEITURA EM HISTÓRIA ORAL. Porto velho: Ed. EDUFRO, 2001.

ORALIDADE, TEXTO E HISTÓRIA: PARA LER A HISTÓRIA ORAL. São Paulo: Ed. Loyola, 1999.

. SEIS ENSAIOS DE HISTÓRIA ORAL. Caderno de Criação: 37/57, UFRO/Centro de Hermenêutica do Presente, nº. 15, ano V, Porto Velho: junho, 1998.

CALDEIRA, Teresa. CIDADE DE MUROS: CRIME, SEGREGAÇÃO E CIDADANIA EM SÃo PAULO. São Paulo: Ed. 34/EDUSP, 2000.

CANCLINI, Nestor Garcia, CULTURAS HÍBRIDAS. São Paulo: EDUSP, 2003.

DIFERENTES, DESIGUAIS, DESCONECTADOS. Rio de Janeiro: Ed. UFRJ, 2007.

CANDIDO, Antonio. OS PARCEIROS DO RIO BONITO. São Paulo: Editora 34, 2001.

CARVAlho, Maria do Carmo Brant. A PRIORIZAÇÃo DA FAMília NA AGENDA DA POLÍTICA SOCIAL. In: A família contemporânea em debate, São Paulo: Ed. IEE/PUC - SP e Fapesp, 1995.

CARVALHO, José Murilo de. CIDADANIA NO BRASIL. Rio de Janeiro: Ed. Civilização Brasileira, 2008. 
CASTELLS, Manuel. O PODER DA IDENTIDADE. São Paulo: Ed. Paz e Terra, 2000.

CORRÊA, Roberto Lobato. O ESPAÇO URBANO. São Paulo: Ed. Ática, 1993.

, CULTURA, ESPAÇO E O URBANO. Rio de Janeiro: Ed. UERJ, 2006.

COSTA, Fernando Braga. GARIS: UM ESTUDO DE PSICOLOGIA SOBRE INVISIBILIDADE PÚBLICA. São Paulo: IP/USP, 2002.

DALLARI, Dalmo de Abreu. DIREITOS HUMANOS E CIDADANIA. São Paulo: Ed. Moderna, 1998. DAMATTA, Roberto. A CASA E A RUA. Guanabara: Rocco, 1991.

DIÁRIO OFICIAL DA UNIÃO. LEI No 10.257, de 10/7/2001 ESTATUTO DA CIDADE, Seção I (Atos do Poder Legislativo). Edição No 133, de 11/7/2001.

DURHAM, Maria Eunice. A SOCIEDADE VISTA DA PERIFERIA. In: (URL: http://www.anpocs.org.br/portal/publicacoes/rbcs_00_01/rbcs01_07.htm). Visto em 10/01/09.

ECO, Umberto. OS LIMITES DA INTERPRETAÇÃO. São Paulo, Perspectiva, 1995.

ENGELS, Friedrich. A ORIGEM DA FAMÍLIA, DA PROPRIEDADE PRIVADA E DO ESTADO. Rio de Janeiro: Ed. Bertrand, 2000.

FECHIO, Fermino; MARICATO, Ermínia. A LUTA PELO DIREITO DE MORAR. Revista Travessia, São Paulo: setembro/dezembro 1992.

FERNANDES, Bernardo Mançano. MST: FORMAÇÃo E TERRITORIALIZAÇÃO. São Paulo: Ed. Hucitec, 1999.

FERREIRA, (1) Gerusa Pires. ORALIDADE EM TEMPO E ESPAÇO. São Paulo: Ed. EDUC/FAPESP, 1999.

AS ARMADILHAS DA MEMÓRIA E OUTROS ENSAIOS. São Paulo: Atelier Editorial, 2003.

FERREIRA (2), Marieta de Moraes (org.). ENTREVISTAS: ABORDAGENS E USOS DA HISTÓRIA ORAL. Rio de Janeiro: Ed. Fundação Getúlio Vargas, 1994.

FERREIRA (3), João Sette Whitaker. GLOBALIZAÇÃo E URBANIZAÇÃo

SUBDESENVOLVIDA. São Paulo: Rev. São Paulo em Perspectiva, vol. 14, nº 04, 2000.

FISCHLER, Claude. A MCDONALDIZAÇÃO DO MUNDO. In: FLANDRIN, Jean-Louis, FLANDRIN, Jean-Louis, MONTANARI, Massimo. HISTÓRIA DA ALIMENTAÇÃO. São Paulo: Ed. Estação Liberdade, 1998.

FREIRE, Gilberto. CASA GRANDE E SENZALA. 51를. Ed. Rio de Janeiro: Ed. Record, 1998.

FRÚGOLI JR, Heitor. CENTRALIDADES EM SÃO PAULO. São Paulo: Ed. Cortez/EDUSP, 2000.

FURTADO, Celso. FORMAÇÃO ECONÔMICA DO BRASIL. São Paulo: Companhia Editora

Nacional, Publifolha, 2000.

GALLIAN, Dante Marcello. 75X75 EPM/UNIFESP, UMA HISTÓRIA, 75 VIDAS. São Paulo: Ed.

UNIFESP, 2008.

GOMES, Paulo César da Costa. A CONDIÇÃO URBANA. Rio de Janeiro: Bertrand Brasil, 2002.

GONH, Maria da Glória. TEORIA DOS MOVIMENTOS SOCIAIS: PARADIGMAS CLÁSSICOS

E CONTEMPORÂNEOS. Ed. Loyola, São Paulo, 1997. 
GONÇALVES FILHO, José Moura. HUMILHAÇÃO SOCIAL: UM PROBLEMA POLÍTICO EM

PSICOLOGIA. São Paulo: Psicologia USP, vol. 9, nº 2, 1998.

GORENDER, JACOB. REGIME TERRITORIAL NO BRASIL ESCRAVISTA. In: STEDILE, João

Pedro. Questão Agrária no Brasil: o debate na Esquerda. São Paulo. Expressão Popular: 2005.

HALBWACHS, Maurice. A MEMÓRIA COLETIVA. São Paulo: Ed. Vértice, 1990.

HENKIN, Louis. THE AGE OF RIGHTS. New York: Colúmbia University Press, 1990.

HOSKINS, Janet. BIOGRAPHICAL OBJECTS: HAW THINGS TELL THE STORIES OF PEOPLES’ LIVES. New York: Routledge, 1998.

IANNI, Octavio. ESTADO E PLANEJAMENTO ECONÔMICO NO BRASIL. Rio de Janeiro: Civilização Brasileira, 1971.

IOKOI, Zilda Márcia Gricoli, OS DILEMAS DA QUESTÃo AGRÁRIA NO BRASIL. In: Terra Livre, publicação da Associação Brasileira de Geógrafos, n. 11/12, p. 138.

os MOVIMENTOS SOcIAIS E A LUTA PELA TERRA. In: Política, Cultura e

Movimentos Sociais. Uberlândia: Programa de Mestrado em História Social/UFU, 2001.

JANUÁRIO, Elias Renato da Silva, TERRITÓRIO, MEMÓRIA E LINGUAGEM. Campinas: Ed. Pontes, 2001.

KOTRE, John. LUVAS BRANCAS: COMO CRIAMOS A NÓS MESMOS ATRAVÉS DA MEMÓRIA. São Paulo: Mandarim, 1997.

KOWARICK, Lucio, A ESPOLIAÇÃO URBANA. Rio de Janeiro: Paz e Terra, 1993. , (org.) AS LUTAS SOCIAIS E A CIDADE. Rio de Janeiro: Paz e Terra, 1994.

, CAPITALISMO E MARGINALIDADE NA AMÉRICA LATINA. Rio de Janeiro: Ed.

Paz e Terra, 1977.

LAUREANO, Delze dos Santos. O MST E A CONSTITUIÇÃO. São Paulo: Ed. Expressão Popular, 2007.

LE CORBUSIER. A CARTA DE ATENAS. São Paulo: Ed. Hucitec/EDUSP, 1989.

LEFEBVRE, Henry. O DIREITO À CIDADE. São Paulo: Ed. Centauro, 2001.

ESPAÇO E POLÍTICA. Belo Horizonte: Ed. UFMG, 2008.

LE GOFF, Jacques. POR AMOR ÁS CIDADES. São Paulo: Ed. UNESP, 1998.

LEWIS, Oscar. ANTROPOlOGIA DE LA POBLEZA: CINCO FAMILIAS. México: Fondo de

Cultura Económica, 1969.

MAFFESOLI, Michel. SOBRE O NOMADISO. Rio de Janeiro: Ed. Record, 2001.

MAGNANI, José Guilherme Cantor. DE PERTO E DE DENTRO: NOTAS PARA UMA

ANTROPOLOGIA URBANA. RBCS, vol. 17, n.49, Junho de 2002.

SANTANA DE PARNAÍBA: MEMÓRIA E COTIDIANO. São Paulo: (URL:

http://www.n-a-u.org/).

MARCÍLIO, Maria Luiza. INFÂNCIA PERDIDA. Revista E-Sesc, Sesc-São Paulo, v. 9, n. 7, p. 36-38, 2001. 
, CAIÇARA: TERRA E POPULAÇÃO. São Paulo: EDUSP, 1986.

CEDHAL, 1993.

FAMÍLIA, MULHER, SEXUALIDADE E IGREJA NO BRASIL. São Paulo: Ed. LoyolaCRESCIMENTO DEMOGRÁFICO E EVOLUÇÃO AGRÁRIA PAULISTA 1700-

1836. São Paulo: Ed. HUCITEC, 2000.

MARICATO, Ermínia (org.). A PRODUÇÃo CAPITALISTA DA CASA (E DA CIDADE) NO

BRASIL INDUSTRIAL. São Paulo: Ed. AlfaOmega, 1979.

A BOMBA RELÓGIO DAS CIDADES BRASILEIRAS. In: (URL: http://www.usp.br/fau/depprojeto/labhab/04textos/exclusao.doc) Visto em 10/01/09.

URBANIZAÇÃO NO BRASIL: A MODERNIZAÇÃO EXCLUDENTE. São Paulo: Família Cristã, vol. 3, 2001

URBANISMO NA PERIFERIA DO MUNDO GLOBALIZADO: METRÓPOLES

BRASILEIRAS. São Paulo: Rev. São Paulo em Perspectiva, vol. 14, nº 04, p. 21-33, 2000.

MARTINS, José de Souza (org.). (DES) FIGURAÇÕES: A VIDA COTIDIANA NO IMAGINÁRIO

ONÍRICO DA METRÓPOLE. São Paulo: Hucitec, 1996.

MEIHY, José Carlos Sebe Bom. MANUAL DE HISTÓRIA ORAL 5a ed. São Paulo: Loyola, 2005.

, HISTÓRIA ORAL: COMO FAZER, COMO PENSAR. São Paulo: Contexto, 2007.

A COLÔNIA BRASILIANISTA. São Paulo: Nova Stella Editorial, 1990.

(RE) INTRODUZINDO HISTÓRIA ORAL NO BRASIL. São Paulo: Ed. Xamã, 1996.

MUNFORD, Lewis, A CIDADE NA HISTÓRIA. São Paulo: Martins Fontes, 2001.

NEGRETTI, Adriana et al. INDUSTRIALIZAÇÃO, URBANIZAÇÃo E MIGRAÇÕES SÃo

PAULO - SÉCULOS XIX E XX. São Paulo: FFCH-USP, (Série Iniciação, vol. 02), 1995.

NORA, Pierre (org.) ENSAIOS DE EGO-HISTÓRIA. Lisboa: Edições 70, 1989.

NOVINSKY, Sônia Novinsky. AS MOEDAS ERRANTES - NARRATIVAS DE UM CLÃ

GERMANO JUDAICO CENENÁRIO. São Paulo: FFLC/USP, 2001. (Tese de Doutorado).

OLIVEIRA, Cássia Milena Nunes de. A LUTA Do CAMPO CHEGA À CIDADE: HISTÓRIA DE

VIDA DE JOVENS ASSENTADOS DO MST. São Paulo: FFLCH/USP, 2009 (Relatório de Qualificação).

ORLANDI, Eni Puccinelli. (org.). DISCURSO FUNDADOR. Campinas: Ed. Pontes, 2003.

AS FORMAS DO SILÊNCIO NO MOVIMENTO DOS SENTIDOS. Campinas: Ed.

UNICAMP, 1997.

CIDADE ATRAVESSADA: OS SENTIDOS PÚBLICOS NO ESPAÇO URBANO.

Campinas: Ed. Pontes, 2001.

OSMAN, Samira Adel. CAMINHOS DA IMIGRAÇÃo ÁRABE EM SÃO PAULO - HISTÓRIA

ORAL DE VIDA FAMILIAR. São Paulo: FFLCH/USP, 1998. (Dissertação de Mestrado).

PERUZZO, Cicília M $M^{a}$ Krolhling. COMUNICAÇÃO NOS MOVIMENTOS POPULARES. Petrópolis:

Vozes, 1998.

PESAVENTO, Sandra Jatahy. O IMAGINÁRIO DA CIDADE: VISÕES LITERÁRIAS DO

URBANO. Porto Alegre: Ed. UFRGS, 2002. 
, HISTÓRIA E HISTÓRIA CULTURAL. Belo Horizonte: Autêntica, 2004.

PINTO, Júlio Pimentel. A LEITURA E SEUS LUGARES. São Paulo: Estação Liberdade, 2004. PIOVESAN, Flávia. DIREITOS HUMANOS E O DIREITO CONSTITUCIONAL

INTERNACIONAL. São Paulo: Saraiva, 2009.

PIRENNE, Henri. AS CIDADES DA IDADE MÉDIA. Lisboa: Publicações Europa-América, 1989.

POLLAK, Michael. MEMÓRIA, ESQUECIMENTO, SILÊNCIO. Estudos Históricos, Rio de Janeiro, vol. 2, n.3, 1989, p.3-15.

PORTELLI, Alessandro. A FILOSOFIA E OS FATOS: NARRAÇÃO, INTERPRETAÇÃO E SIGNIFICADO NAS MEMÓRIAS E NAS FONTES ORAIS. Tempo. Rio de Janeiro, v.1, n.2, 1996.

O QUE FAZ A HISTÓRIA ORAL DIFERENTE. Projeto História, São Paulo, n.14, fev. 1997.

POSTER, Mark. TEORIA CRÍTICA DA FAMÍLIA. Rio de Janeiro: Zahar Ed., 1979.

PRADO JR. A CIDADE DE SÃO PAULO. São Paulo: Ed. Brasiliense, 1983

A REVOLUÇÃO BRASILEIRA. São Paulo, Ed. Brasiliense, 2004.

QUEIROZ, Maria Isaura Pereira de. DIALÉTICA DO RURAL E DO URBANO: EXEMPLOS BRASILEIROS. In: BLAY, Eva Alterman (org.). A Luta pelo Espaço. Petrópolis: Ed. Vozes, 1979.

REIS FILHO, Nestor Goulart. NOTAS SOBRE URBANIZAÇÃO DISPERSA E NOVAS FORMAS DE TECIDO URBANO. São Paulo: Via das Artes, 2006.

(org.) BRASIL: ESTUDOS SOBRE DISPERSÃO URNANA. São Paulo: FAU-USP, 2007, vol. 1.

RIBEIRO, Suzana Lopes Salgado. PROCESSOS DE MUDANÇA NO MST: HISTÓRIA DE UMA FAMÍLIA COOPERADA. Mestrado, São Paulo: FFLCH/USP, 2002.

TRAMAS E TRAUMAS: IDENTIDADES EM MARCHA. São Paulo, FFLCH/USP, 2007. (Tese de Doutorado).

RODRIGUES, Suzy Lagazzi; BRITO, Priscila Salvato. AS OCUPAÇÕES DOS SEM-TETO NA DISCURSIVIDADE DA CIDADE. In: ORLANDI, Eni P. Cidade Atravessada: Campinas: Ed. Pontes, 2001.

ROLNIK, Raquel. O QUE É CIDADE. São Paulo: Ed. Brasiliense, 1995.

ROSENDHL, Zeny; CORRÊA, Roberto Lobato. (orgs). GEOGRAFRIA: TEMAS SOBRE CULTURA E ESPAÇO. Rio de Janeiro: ed. UERJ, 2005.

ROUDINESCO, Elisabeth. A FAMÍLIA EM DESORDEM. Rio de Janeiro: Jorge Zahar Ed., 2003

SACHS, Céline. SÃo PAUlO: POLÍTICAS PÚBLICAS E HABITAÇão POPULAR. São Paulo: Ed. EDUSP, 1999.

SAID, Edward W. ORIENTALISMO: O ORIENTE COMO INVENÇAO DO OCIDENTE. São Paulo: Companhia das Letras, 1990.

SALEN, Tânia. O VELHO E O NOVO: UM ESTUDO DE PAPEIS E CONFLITOS FAMILIARES. Petrópolis: Ed. Vozes, 1980. 
SAMARA, Eni de Mesquista. FAMíliA, MULHERES E POVOAMENTO. São Paulo: EDUSC, 2003. AS MULHERES, O PODER E A FAMÍLIA. São Paulo: Marco Zero, 1989.

SANTOS, (1) Milton. PENSANDO O ESPAÇO DO HOMEM. São Paulo: Ed. Hucitec, 1997. , METAMORFOSES DO ESPAÇO HABITADO. São Paulo: Ed. Hucitec, 1997. , POBREZA URBANA. São Paulo/Recife: Ed. Hucitec, 1978.

, POR UMA OUTRA GLOBALIZAÇÃO: DO PENSAMENTO ÚNICO Á CONSCIÊNCIA UNIVERSAL. São Paulo: Record, 2000.

A URBANIZAÇÃO BRASILEIRA. São Paulo: EDUSP, 2005.

SANTOS, Andréa Paula dos. PONTO DE VIDA: CIDADANIA DE MULHERES FAVELADAS. São Paulo: Ed. Loyola, 1996.

SARLO, Beatriz. TEMPO PASSADO, CULTURA DA MEMÓRIA E GUINADA SUBJETIVA. São Paulo: Companhia das Letras, 2005.

SARLO, Beatriz. PAISAGENS IMAGINÁRIAS. São Paulo: EDUSP, 2005.

SARTI, Cynthia. É SINA QUE A GENTE TRAZ (SER MULHER NA PERIFERIA URBANA). Dissertação, São Paulo: FFLCH/USP, 1985.

FAMÍLIAS ENREDADAS. In: ACOSTA, Ana Rojas et al. FAMÍLIA, REDES, LAÇOS E POLÍTICAS PÚBLICAS. São Paulo: 2005.

SAWAIA, Bader. FAMÍLIA E AFETIVIDADE. In: ACOSTA, Ana Rojas. FAMÍLIA, REDES LAÇOS E POLÍTICAS PÚBLICAS. São Paulo: 2005.

SCHESENER, Anita Helena. GRAMSCI: HEGEMONIA E CULTURA. Curitiba: Ed. UFPR, 2001.

SILVA, José Borzacchielo da. O ESTATUTO DA CIDADE E A REFORMA URBANA NO BRASIL. São Paulo: Ed. HUMANITAS (GEOUSP - ESPAÇO E TEMPO, vol. 10), 2001.

SILVA, Fernando Teixeira da. HISTÓRIA E CIÊNCIAS SOCIAIS: ZONA DE FRONTEIRA. In: http://www.scielo.br/pdf/his/v24n1/a06v24n1.pdf .

SILVA, Myrian Sepúlveda. MEMÓRIA COLETIVA E TEMPO SOCIAL. Rio de Janeiro: Ed. Annablume, 2000.

SCHWARTZMAN, Simon. POBREZA, EXCLUSÃO SOCIAL E MODERNIDADE: UMA INTRODUÇÃO AO MUNDO CONTEMPORÂNEO. São Paulo: augurium editora, 2004.

TUAN, Yi-Fu. ESPAÇO E LUGAR: A PERSPECTIVA DA EXPERIÊNCIA. São Paulo: Difel, 1983. VAINFAS, Ronaldo. OS PROTAGONISTAS ANÔNIMOS DA HISTÓRIA: MICRO-HISTÓRIA. Rio de Janeiro: Ed. Campus, 2002.

VARGAS NETTO, Sebastião Leal Ferreira. A MísTICA DA RESISTÊNCIA. São Paulo: FFLCH/USP Tese de Doutorado, 2007.

VENTURINI, Luis Antonio Bittar. RETRATOS DE UM MUNICÍPIO: ITAPECERICA DA SERRA. Osasco: Ed. Edifieo, 2005.

VIANA CAMARgo, Rui Geraldo. A FAMília NA TRAVESSIA DO MILÊNiO. In: URL: http://www.buscalegis.ufsc.br/revistas/index.php/buscalegis/article/view/7513/7080, consultado em 18/03/09. 
WILLIANS, Raymond. O CAMPO E A CIDADE NA HISTÓRIA E NA LITERATURA. São Paulo: Ed. Companhia das Letras, 1989.

ZUKIN, Sharon. PAISAGENS URBANAS PÓS-MODERNAS. In: Antonio Arantes (org.): O espaço da diferença, Campinas: Ed. Papirus, 2000. 


\section{ANEXOS}

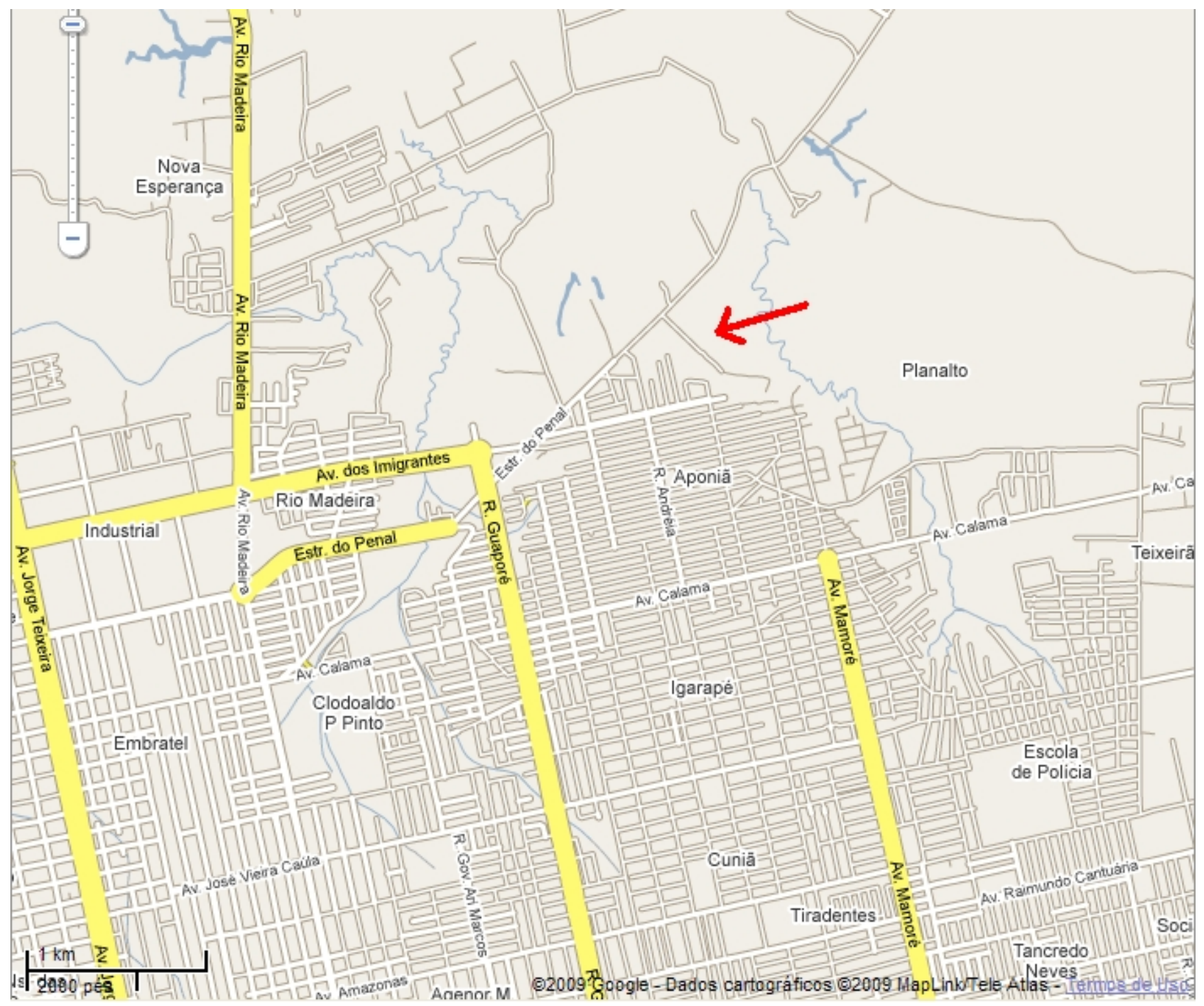

Mapa da região da ocupação Chico Mendes, em Porto Velho.

A seta em vermelho entre a Estrada da Penal, o bairro Aponiã e o Planalto indica a localização da ocupação.

Os créditos desse material cartográfico pertencem ao Google. 


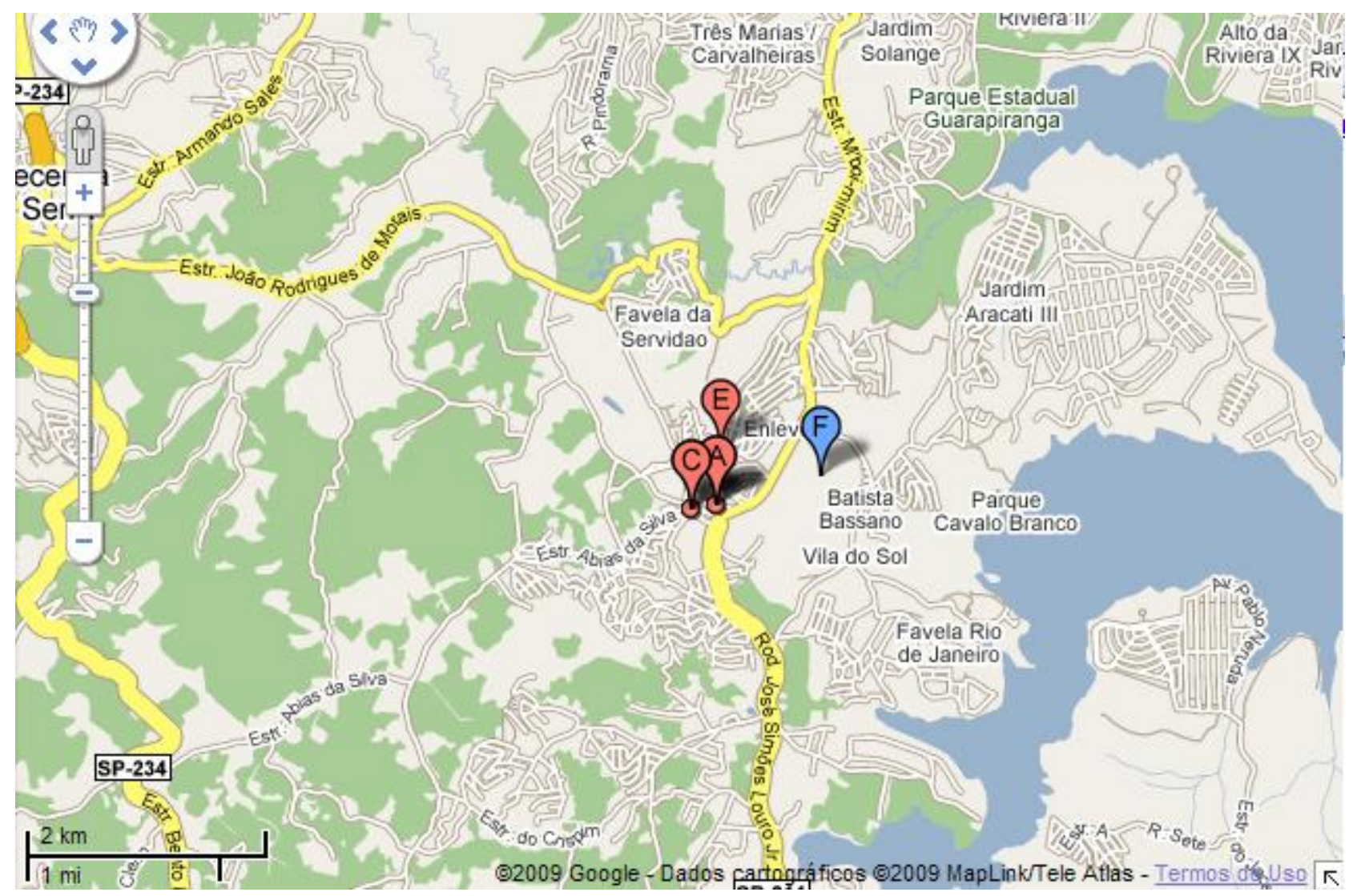

Mapa da região da ocupação João Cândido, em Itapecerica da Serra.

O balão com a letra C indica a localização da ocupação.

Os créditos desse material cartográfico pertencem ao Google. 


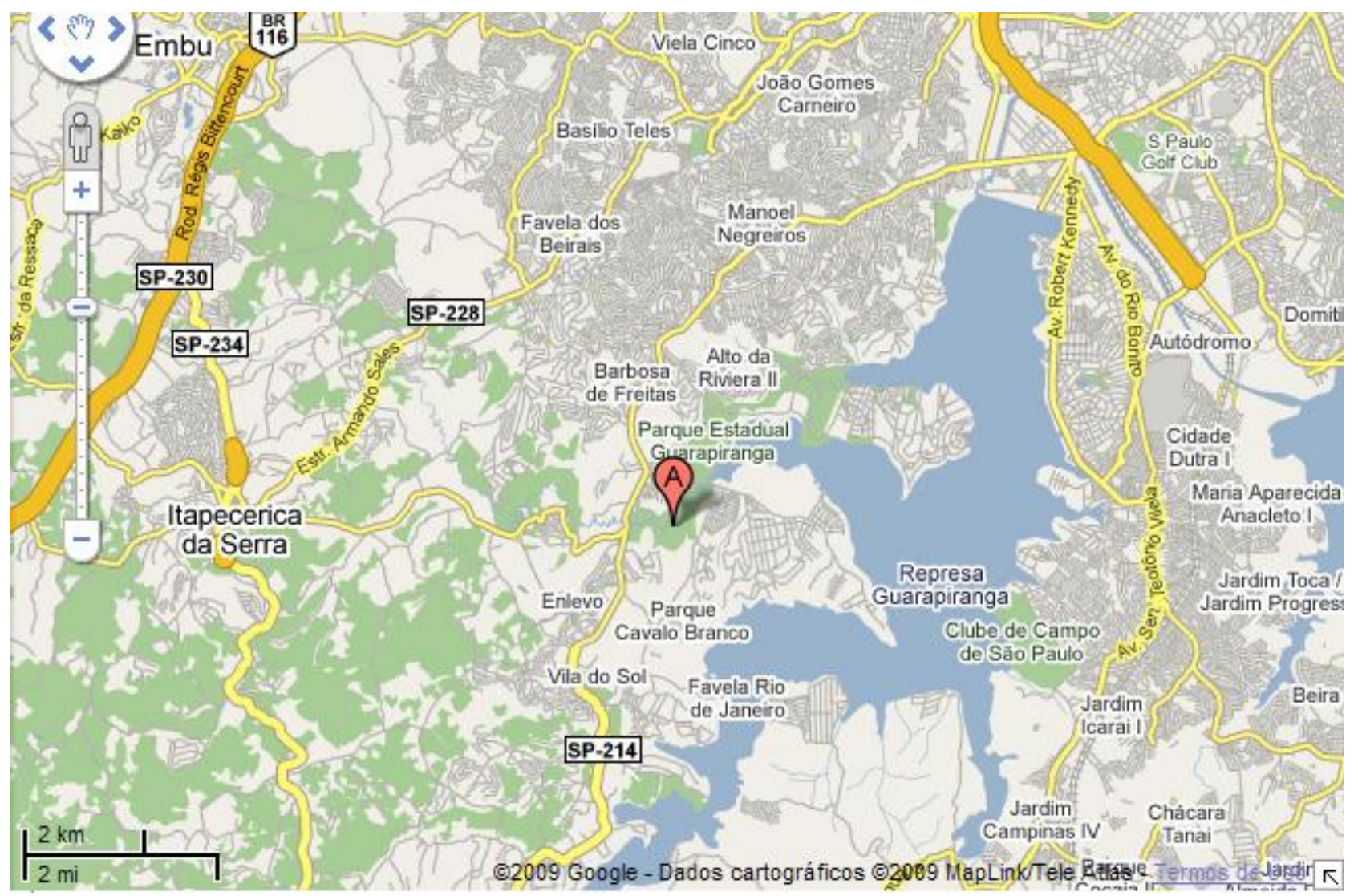

Mapa da região do Jardim Ângela-Menininha, em São Paulo.

O balão vermelho indica parte da área do bairro.

Os créditos desse material cartográfico pertencem ao Google. 


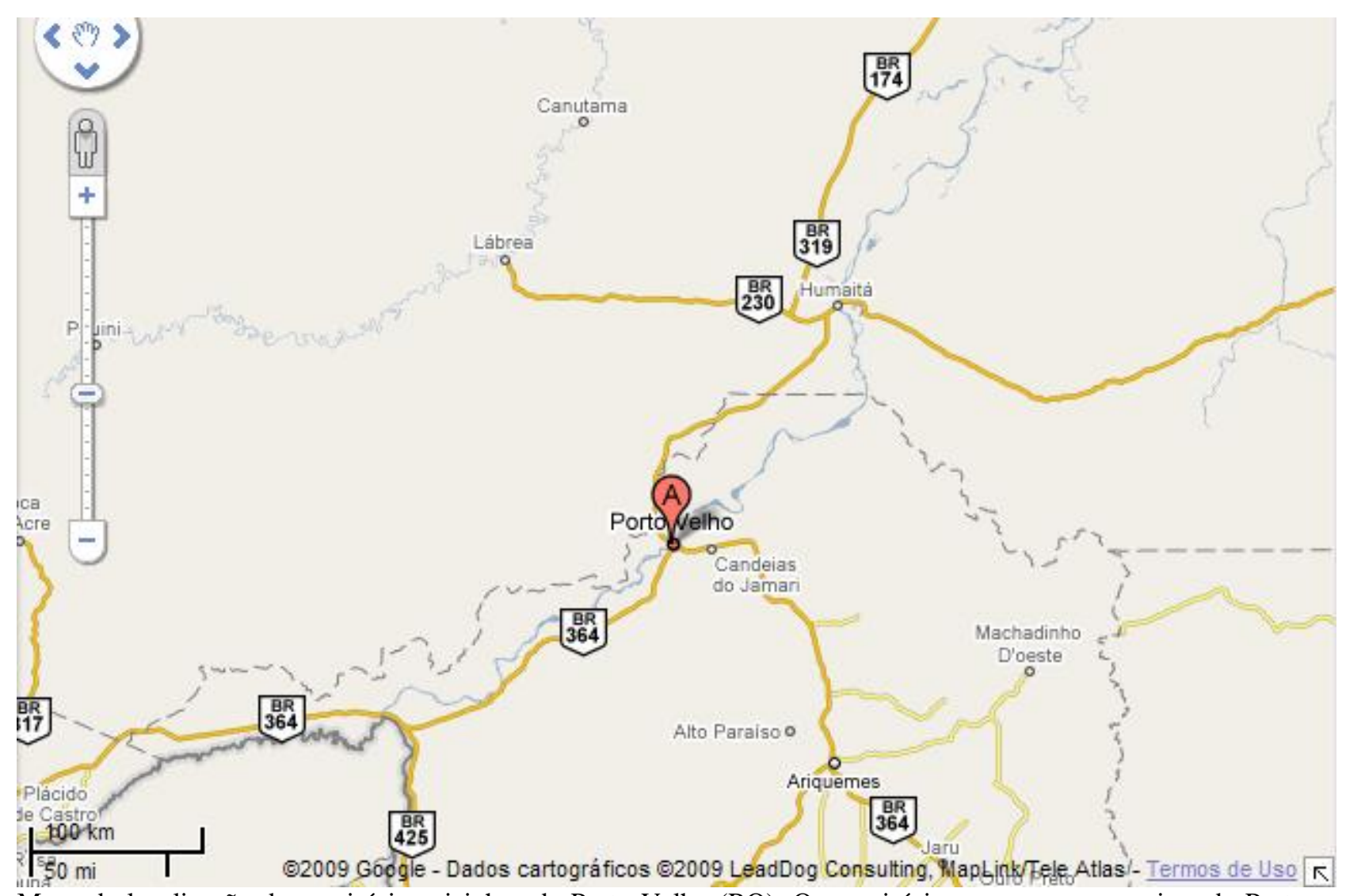

Mapa de localização de municípios vizinhos de Porto Velho (RO). Os municípios que aparecem acima de Porto Velho: Humaitá, Lábrea e Canutama pertencem ao Estado do Amazonas.

O balão vermelho indica a capital do Estado de Rondônia.

Os créditos desse material cartográfico pertencem ao Google. 


\section{GALERIA}

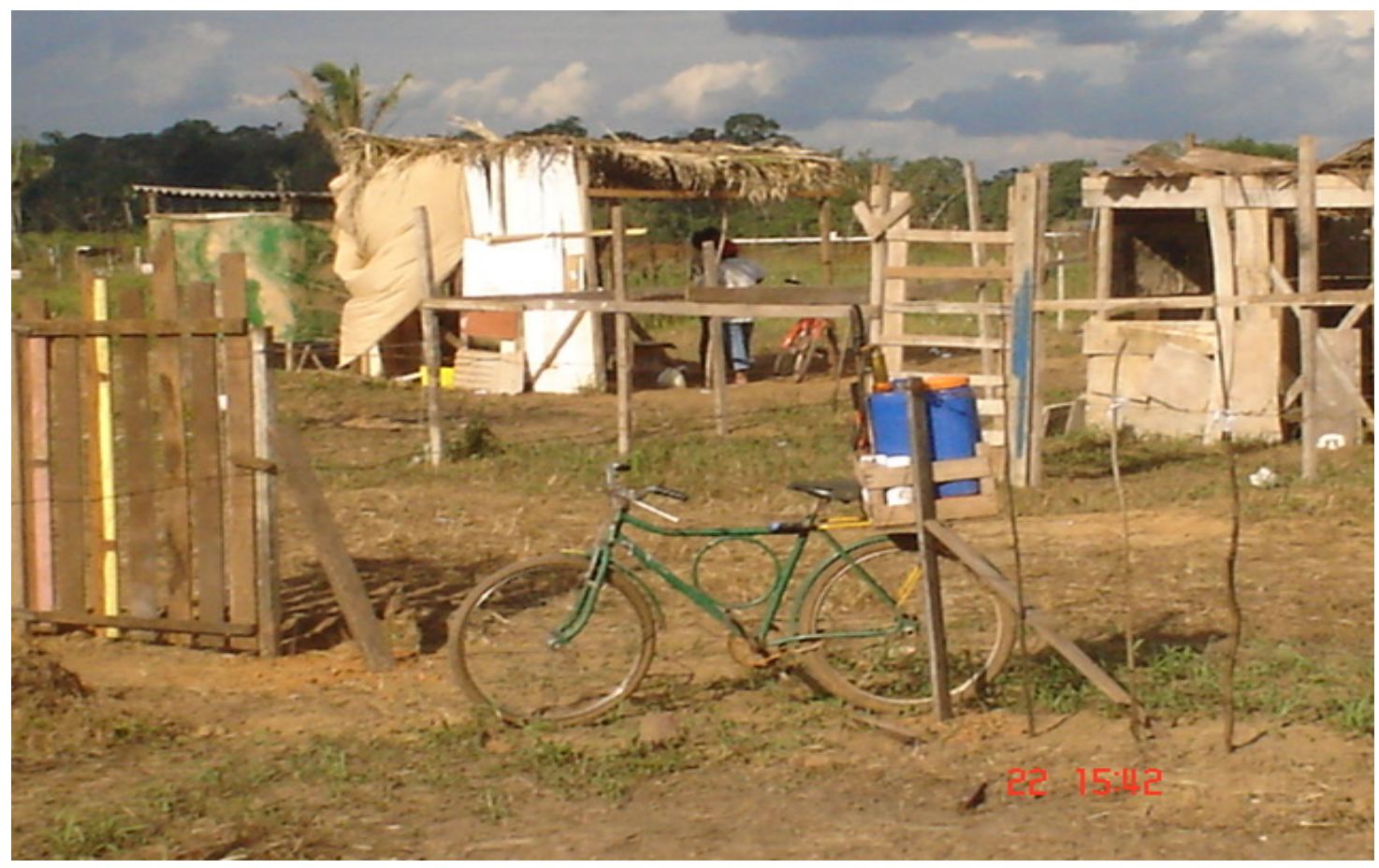

\section{Barracos da ocupação Chico Mendes, em Porto Velho.}

Foto: Tiago Lins de Lima.

Agosto de 2008.

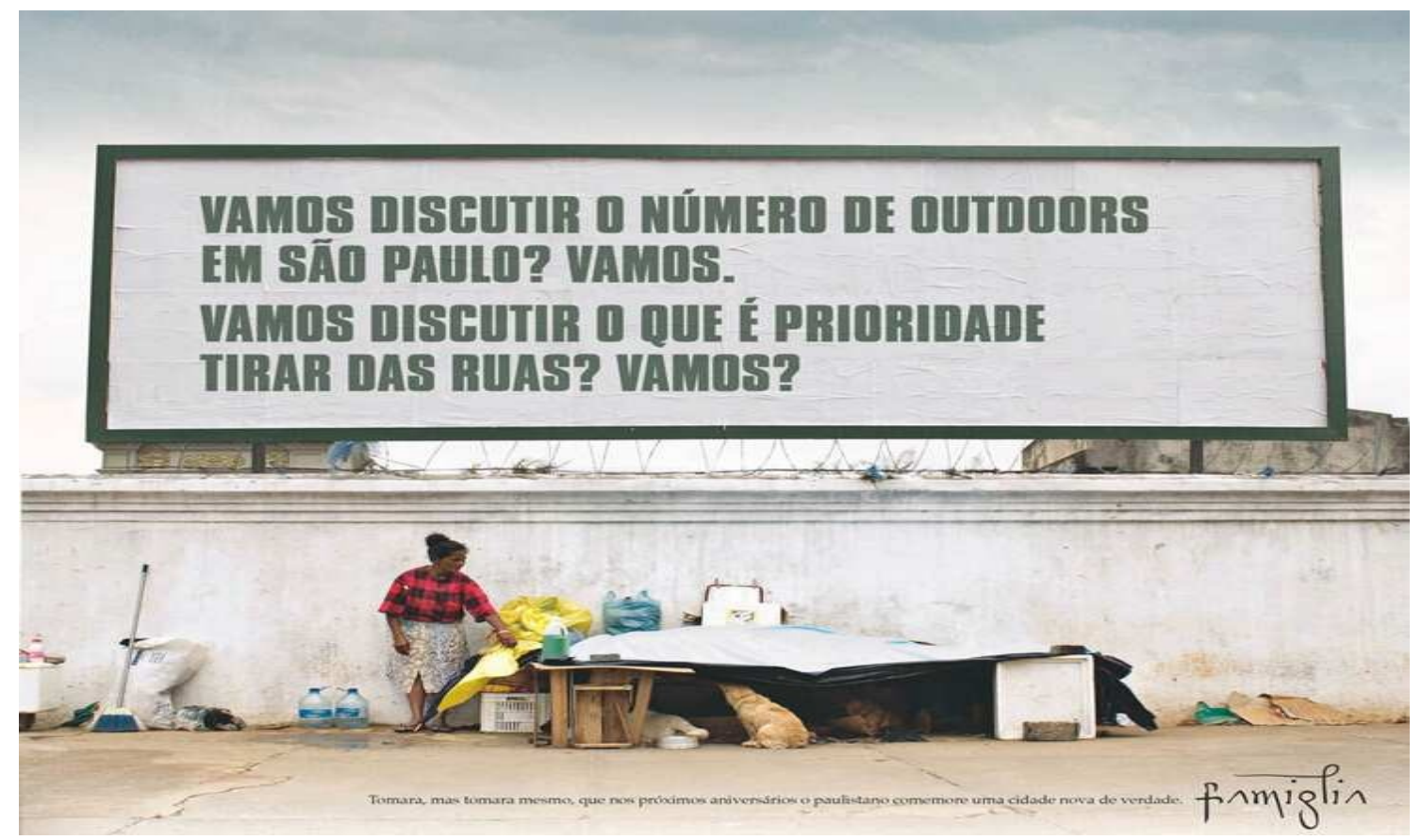

\section{Moradora de rua e outdoor}

Foto: Autor desconhecido. Disponível em http://efeito-colateral.blogspot.com/2007_03_01_archive.html

Novembro de 2007. 


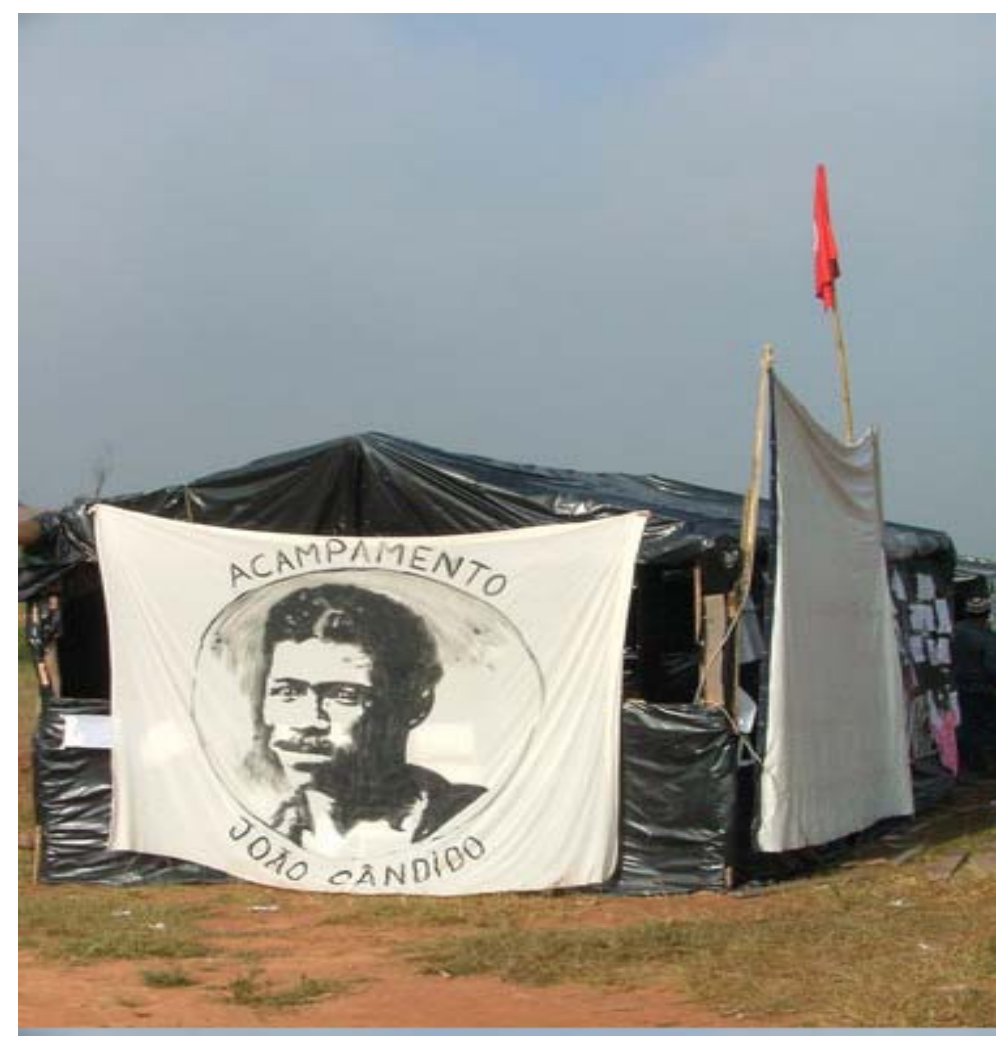

Barraco da ocupação João Cândido, em Itapecerica da Serra.

Foto: Rodrigo Ciríaco. Disponível em http://efeito-colateral.blogspot.com/2007_03 01_archive.html Dezembro de 2007.

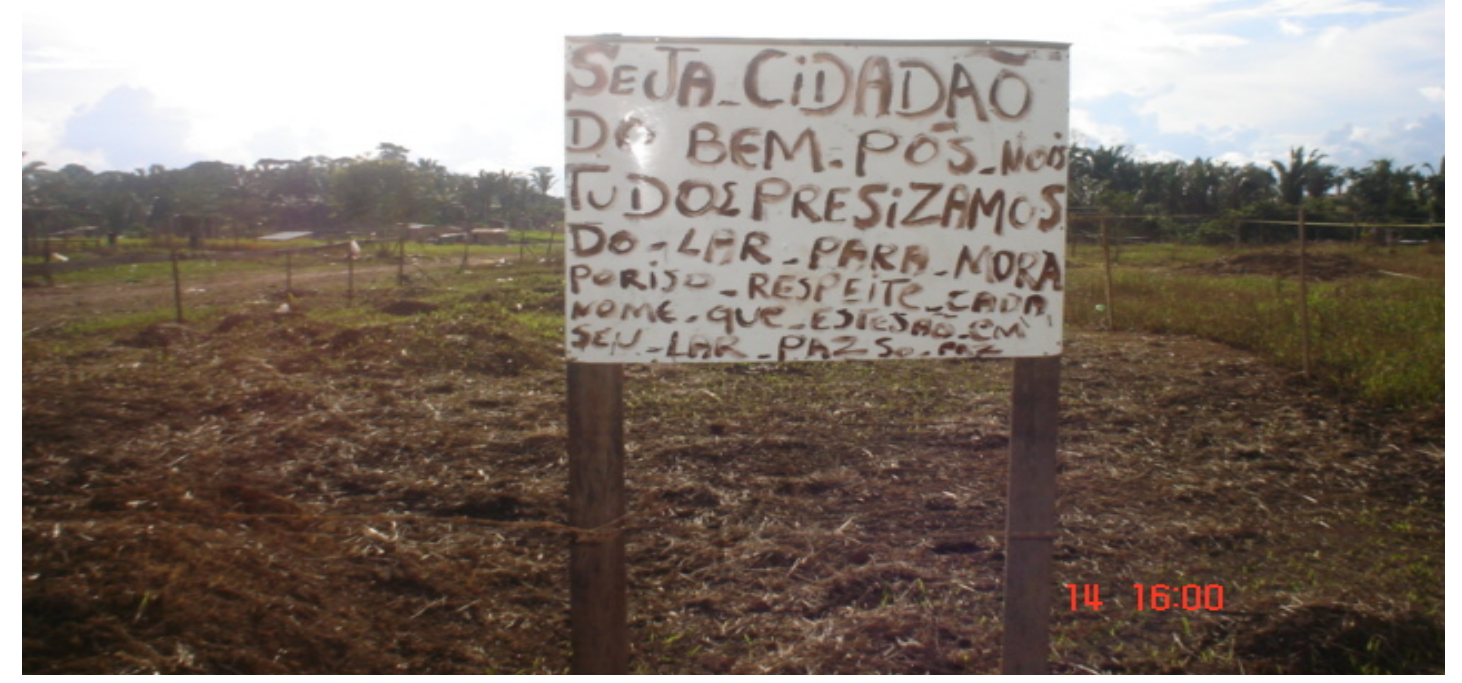

Placa na entrada da ocupação Chico Mendes, em Porto Velho.

Foto: Tiago Lins de Lima.

Julho de 2008. 


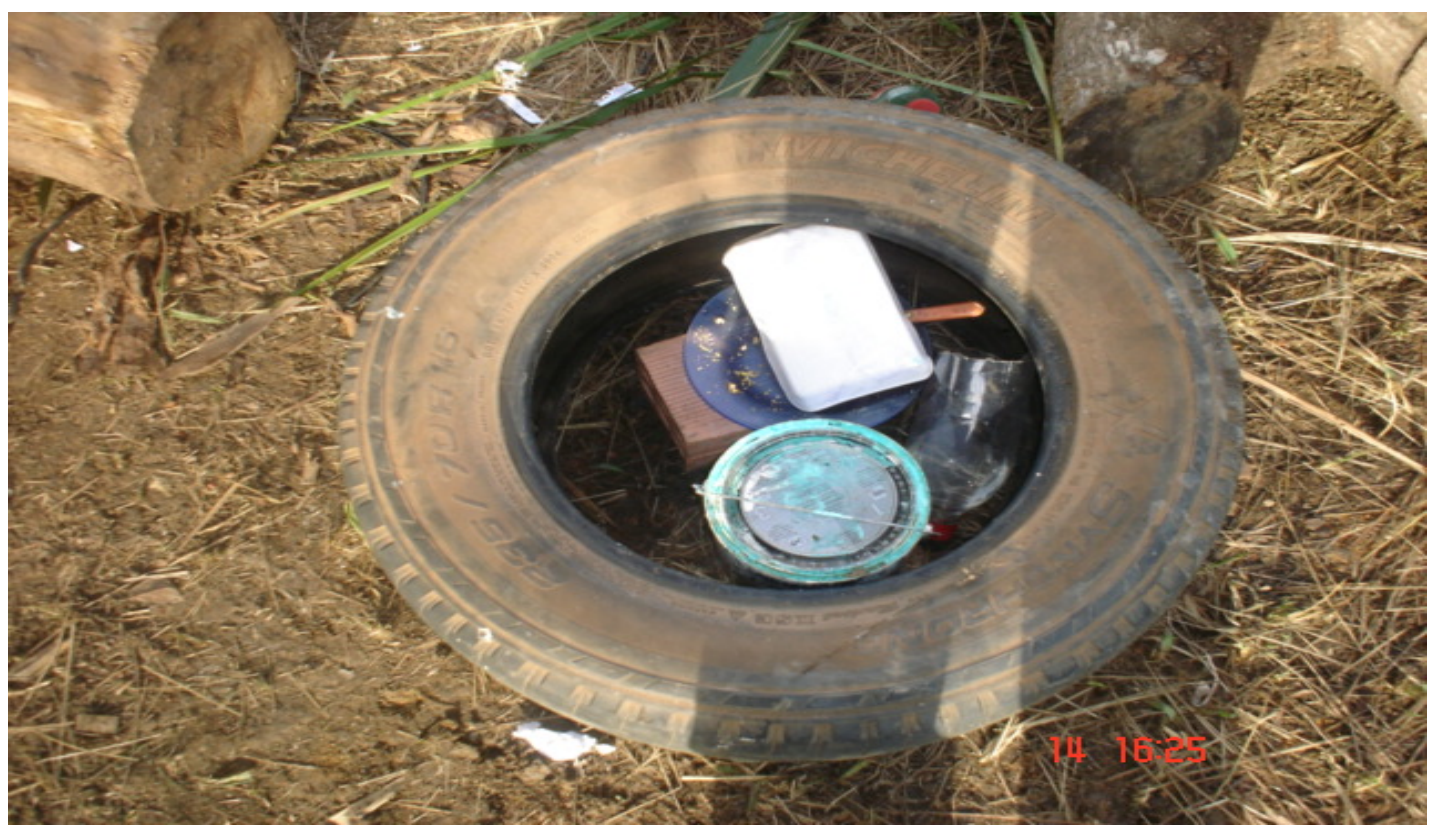

Mesa improvisada na ocupação Chico Mendes, em Porto Velho.

Foto: Tiago Lins de Lima.

Julho de 2008.

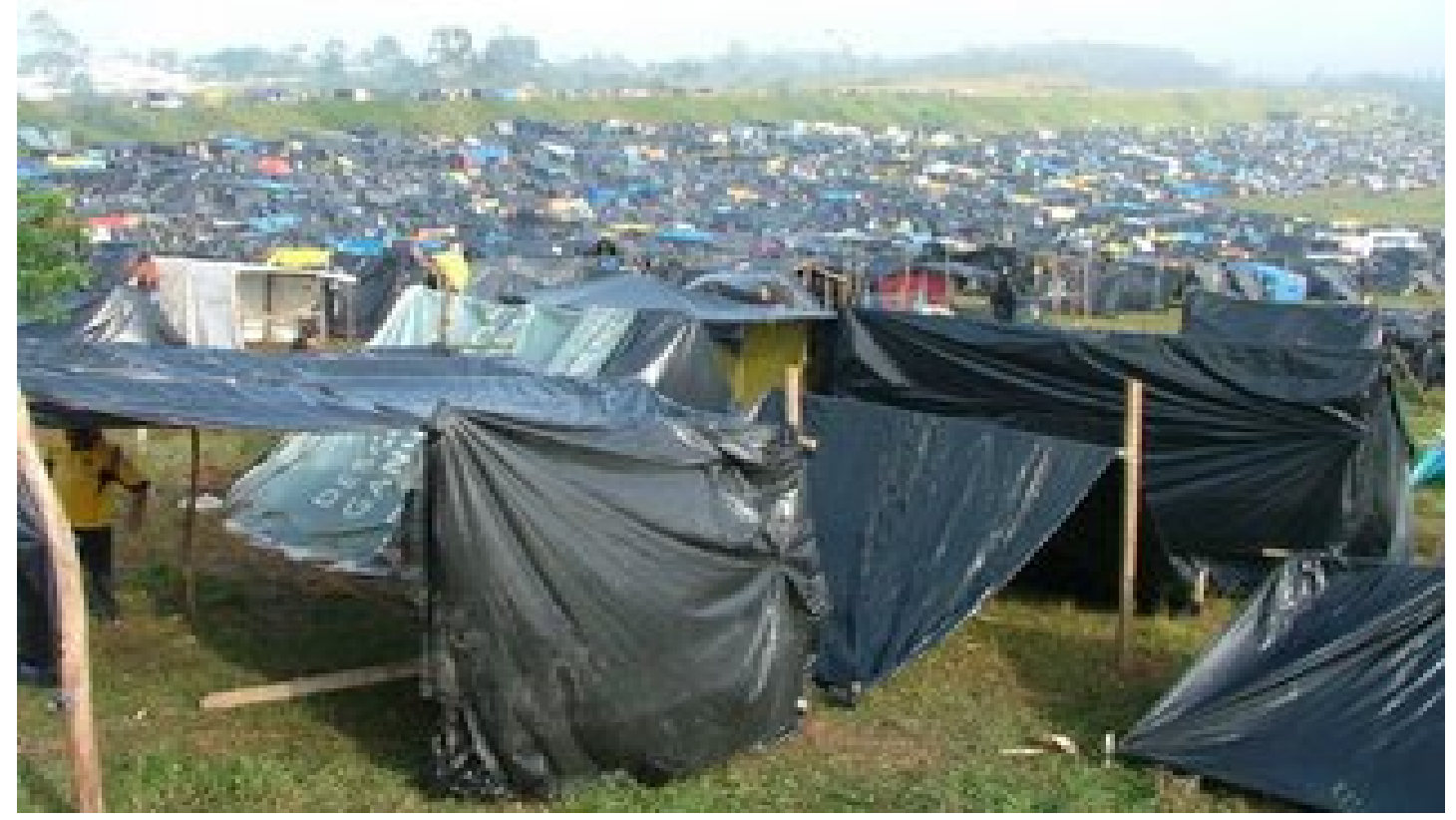

Ocupação João Cândido, em Itapecerica da Serra.

Foto: Rodrigo Ciríaco. Disponível em http://efeito-colateral.blogspot.com/2007_03_01_archive.html Novembro de 2007. 